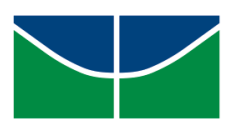

\title{
UnB
}

UNIVERSIDADE DE BRASÍLIA

CENTRO DE ESTUDOS AVANÇADOS MULTIDISCIPLINARES

PÓS-GRADUAÇÃO EM DESENVOLVIMENTO

SOCIEDADE E COOPERAÇÃO INTERNACIONAL

SÁVIA MARIA LEITE RODRIGUES

\section{DISCRICIONARIEDADE E LITIGÂNCIA INTRAGOVERNAMENTAL NA GESTÃ̃ DE POLÍTICAS PÚBLICAS}

Brasília

2017 


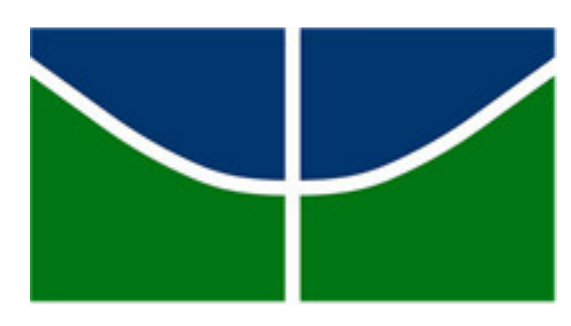

UNIVERSIDADE DE BRASÍLIA

Centro de Estudos Avançados Multidisciplinares Programa de Pós-Graduação em Desenvolvimento, Sociedade e Cooperação Internacional

\section{DISCRICIONARIEDADE E LITIGÂNCIA INTRAGOVERNAMENTAL NA GESTÃO DE POLÍTICAS PÚBLICAS}

Sávia Maria Leite Rodrigues 


\section{Discricionariedade e litigância intragovernamental na gestão de políticas públicas}

Dissertação apresentada ao Programa de Pós-Graduação em Desenvolvimento, Sociedade e Cooperação Internacional da Universidade de Brasília, como requisito parcial para obtenção do título de Mestre em Desenvolvimento, Sociedade e Cooperação Internacional. Área de concentração: Desenvolvimento e Políticas Públicas

Orientadora: Prof. ${ }^{a}$ Dr. ${ }^{a}$ Magda de Lima Lúcio

Brasília - DF

Março de 2017 


\section{FICHA CATALOGRÁFICA}

Autorizo a reprodução ou a divulgação total ou parcial deste trabalho, por qualquer meio convencional ou eletrônico, para fins de estudo e pesquisa, desde que citada a fonte.

RODRIGUES, Sávia

Discricionariedade e litigância intragovernamental na gestão de políticas públicas / Sávia Maria Leite Rodrigues; Orientadora Magda de Lima Lúcio. - Brasília, 2017.

$165 \mathrm{f.}$ : il.

Dissertação (Mestrado). Universidade de Brasília, 2017.

1 - Gestão de políticas públicas. 2 - ato administrativo. 3 Discricionariedade. 4 - Litigância intragovernamental. 5 Conflito administrativo. 6 -Democracia. 
UNIVERSIDADE DE BRASÍLIA

CENTRO DE ESTUDOS AVANÇADOS MULTIDISCIPLINARES

PROGRAMA DE PÓS-GRADUAÇÃO EM DESENVOLVIMENTO, SOCIEDADE E COOPERAÇÃO INTERNACIONAL

\section{Sávia Maria Leite Rodrigues}

\section{Discricionariedade e litigância intragovernamental na gestão de políticas públicas}

Dissertação apresentada ao Programa de Pós-Graduação em Desenvolvimento, Sociedade e Cooperação Internacional da Universidade de Brasília, como requisito parcial para obtenção do título de Mestre em Desenvolvimento, Sociedade e Cooperação Internacional.

Área de concentração: Políticas e gestão pública para o desenvolvimento

Data da defesa: 10 de março de 2017

Banca Examinadora:

\section{Dra. Magda de Lima Lúcio}

Professora do Programa de Pós-Graduação em Desenvolvimento, Sociedade e Cooperação Internacional da Universidade de Brasília

\section{Dr. Doriana Daroit}

Professora do Programa de Pós-Graduação em Desenvolvimento, Sociedade e Cooperação Internacional da Universidade de Brasília

Dr. Arnaldo Sampaio de Moraes Godoy

Professor do Centro Universitário de Brasília

\section{Dr. Breitner Tavares}

Professor do Programa de Pós-Graduação em Desenvolvimento, Sociedade e Cooperação Internacional da Universidade de Brasília 


\section{Agradecimentos}

A Deus.

Aos meus pais Maria Nair (in memoriam) e José, por simplesmente tudo.

Ao meu irmão Ronaldo, por ser exemplo de esforço e dedicação.

Aos meus filhos Yasmin e Gustavo, por serem a minha razão.

A Rui, pelos meus filhos e pelos conselhos.

A minha orientadora, Prof. Magda, pela grandeza humana e docente.

A tantos seres queridos, muito queridos, que acreditaram em mim, me estimularam e que se alegram comigo. 


\section{Epígrafe}
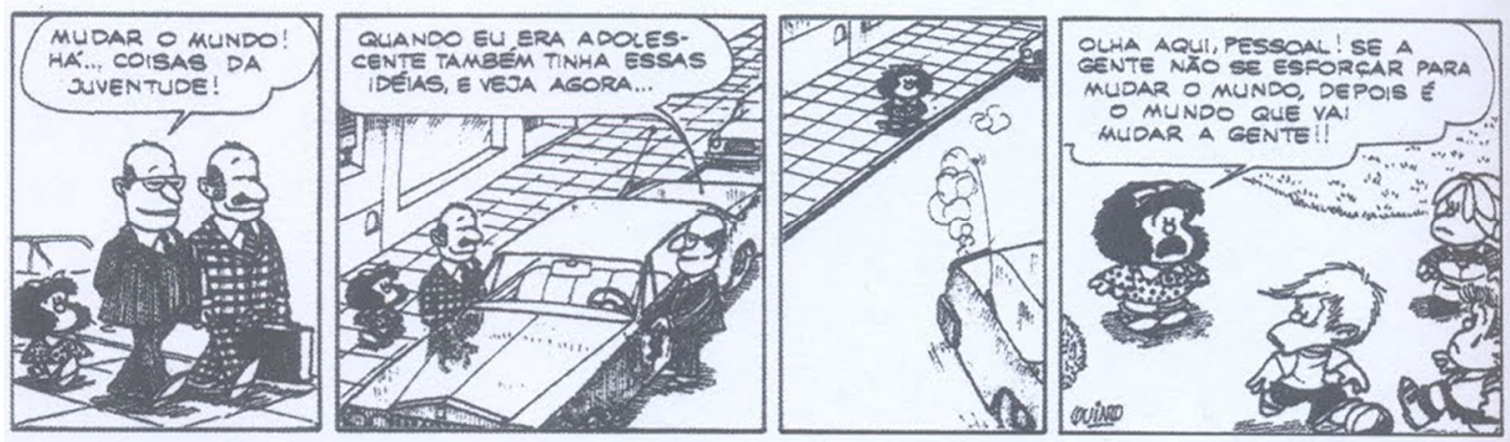

https://vousermembrodomp.files.wordpress.com/2012/02/mafalda_mudar_mundo.jpg 


\section{Resumo}

RODRIGUES, S. M. L. Discricionariedade e litigância intragovernamental na gestão de políticas públicas.

- Gestão pública. 2016, 165 f. Dissertação (mestrado) - Programa de Pós-Graduação em Desenvolvimento, Sociedade e Cooperação Internacional, Universidade de Brasília, Brasília, 2017.

Este trabalho tem como objetivo identificar em que medidas os conflitos administrativos, elevados à condição de litigância intragovernamental, impactam na gestão pública, especialmente na efetivação das políticas públicas, gerando empecilhos ao atendimento dos fins do Estado na consecução do bem-estar comum.

Analisa a legitimação democrática na investidura do poder político e a necessidade de que as políticas públicas, conformadas como proposta prevalente, privilegiando a concepção de agência, de acordo com a expressão dos politólogos Guillermo O'Donnell e Robert Dahl.

Parte da avaliação do ato administrativo, como forma de expressão da vontade do Estado e contempla as possibilidades de exercício da discricionariedade, em contraponto com a construção democrática.

Ao investigar o contexto gerador da litigância intragovernamental propõe que os obstáculos aparentemente oferecidos sejam convertidos em pauta para a construção gerencial plúrima e ampla, perspectiva em que o processo democrático efetivamente se consolida e se aprimora.

Expressões e Palavras-chave:

ATO ADMINISTRATIVO. DISCRICIONARIEDADE. GESTÃO PÚBLICA. LITIGÂNCIA INTRAGOVERNAMENTAL. BRASIL.

\section{Abstract}


This paper aims to identify in which measures administrative conflicts, elevated to the condition of intragovernmental litigation, impact on the public management, especially in the effectiveness of the public policies, generating obstacles to the fulfillment of the ends of the state in the attainment of the common welfare.

It analyzes the democratic legitimacy in the inauguration of political power and the need for the public policies, conformed as a prevailing proposal, privileging the conception of agency, according to the expression of political scientists Guillermo O'Donnell and Robert Dahl.

Part of the evaluation of the administrative act, as a form of expression of the will of the state and contemplates the possibilities of exercising discretion, as opposed to the democratic construction.

In investigating the context that generates intragovernmental litigation, it proposes that the obstacles apparently offered be converted into a guideline for a broad and plentiful managerial construction, a perspective in which the democratic process effectively consolidates and improves.

\section{Expressions and keywords:}

ADMINISTRATIVE ACT. DISCRICIONARITY. PUBLIC ADMINISTRATION. INTRAGOVERNMENTAL LITIGATION. BRASIL 


\section{LISTA DE ABREVIATURAS E SIGLAS}

AGU Advocacia-Geral da União

ADCT Ato de Disposições Constitucionais Transitórias

ADI Ação Direta de Inconstitucionalidade

CGU Consultoria-Geral da União

CONAQ Coordenação Nacional das Comunidades Negras Rurais Quilombola

DPP Departamento de Patrimônio e Probidade

FCP Fundação Cultural Palmares

FUNAI Fundação Nacional do Índio

GSI Gabinete de Segurança Institucional

IBAMA Instituto Brasileiro do Meio Ambiente e dos Recursos Naturais Renováveis

ICMBio Instituto Chico Mendes de Conservação da Biodiversidade

IPHAN Instituto do Patrimônio Histórico e Artístico Nacional

IN Instrução Normativa

INCRA Instituto Nacional de Colonização e Reforma Agrária

MINC Ministério da Cultura

MD Ministério da Defesa

MDA Ministério do Desenvolvimento Agrário

MDS Ministério do Desenvolvimento Social e Combate à Fome

MJ Ministério da Justiça

MMA Ministério do Meio Ambiente

MP Ministério do Planejamento, Desenvolvimento e Gestão

MPF Ministério Público Federal

MRE Ministério das Relações Exteriores

OIT Organização Internacional do Trabalho

PGF Procuradoria Geral Federal

PGU Procuradoria Geral da União

PPGDSCI Programa de Pós-Graduação em Desenvolvimento Sociedade e Cooperação Internacional

RTID Relatório Técnico de Identificação e Delimitação

SDH Secretaria Especial de Direitos Humanos 
SEPPIR Secretaria Especial de Políticas de Promoção da Igualdade Racial

SFB

SGCT

SPU

SAG

SAJ

STF
Serviço Florestal Brasileiro

Secretaria Geral de Contencioso

Secretaria de Patrimônio da União

Subchefia de Análise e Acompanhamento de Políticas Governamentais da

Casa Civil da Presidência da República

Subchefia de Assuntos Jurídicos Casa Civil da Presidência da República

Supremo Tribunal Federal 


\section{LISTA DE QUADROS}

Quadro 1 - Programação da Consulta Pública das comunidades quilombolas quanto à alteração da Instrução Normativa $n^{\circ}$ 20, do INCRA ....................................... 82 


\section{SUMÁRIO}

1. Percurso Metodológico

II. O AMBIENTE DE GERAÇÃO DA LITIGÂNCIA INTRAGOVERNAMENTAL .........................9

1. IMPORTANTES CONCEITOS PRELIMINARES: Estado, GOVERno, REPÚbliCA, DEMOCRACIA,

DISCRICIONARIEDADE E GESTÃo DE POLÍTICAS PÚBLICAS E AGÊNCIA...................................................

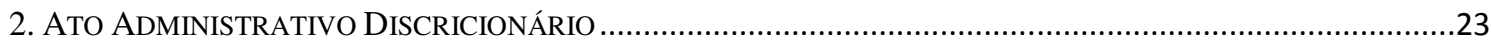

3. A CONFIGURAÇÃO DA LITIGÂNCIA INTRAGOVERNAMENTAL .............................................................39

4. Cotejo dA LiTigÂNCIA InTRAgOVERnAMENTAL, EM FACE dos CONCEITOS DE DEMOCRACIA, AGÊNCIA,

ESTAdo, REPÚbliCA, DisCRICIONARIEDADE E GESTÃo DE POLÍTICAS PÚBLICAS.

III. A CONFIGURAÇÃO DA LITIGÂNCIA INTRAGOVERNAMENTAL E O TRATAMENTO DISPENSADO: A POLÍTICA DE TITULAÇÃO DE COMUNIDADES QUILOMBOLAS E AS POLÍTICAS DE CUNHO AMBIENTAL, DE SEGURANÇA NACIONAL E DE NATUREZA AGRÁRIA. APLICABILIDADE DO DECRETO No 4.887, DE 20 DE NOVEMBRO DE 2003...........66

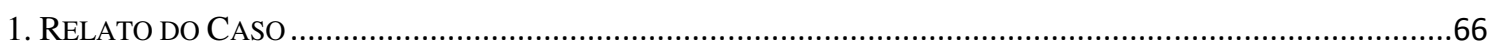

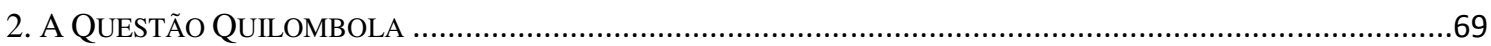

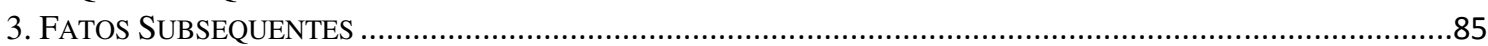

IV. A LITIGÂNICA INTRAGOVERNAMENTAL COMO ENTRAVE À GESTÃO............................88

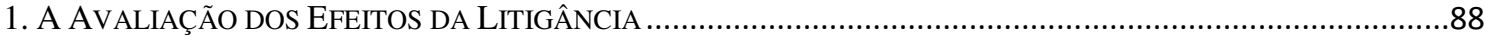

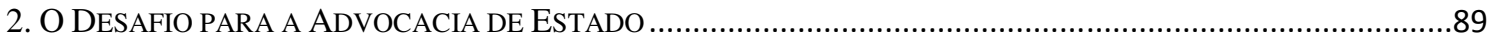

3. As Possibilidades de CONTRIBUiÇão da AdVOCACIA DE Estado: Resultados Percebidos COMO

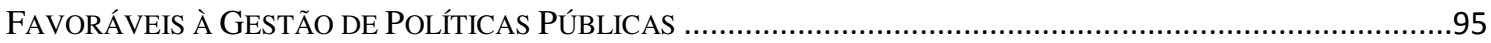

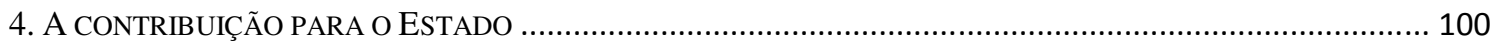

V. NOVA ABORDAGEM PARA A LITIGÂNCIA: SEU APROVEITAMENTO PARA APRIMORAR

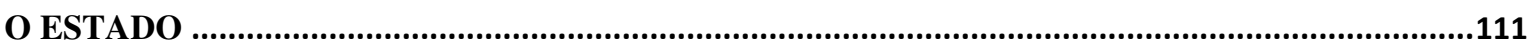

1. A IDENTIFICAÇÃO DA LITIGÂNCIA INTRAGOVERNAMENTAL COMO OPORTUNIDADE.................................. 111

2. PREVENIR OU UTILIZAR O CONFLITO COMO INSTRUMENTO DE APRIMORAMENTO DA GESTÃO?............... 116

3. GERENCIAMENTO E IMPACTO DE UMA NOVA ABORDAGEM DA LITIGÂNCIA.......................................... 117

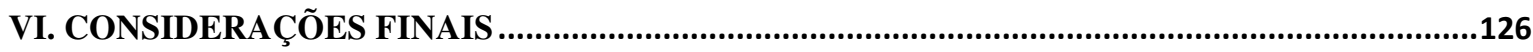

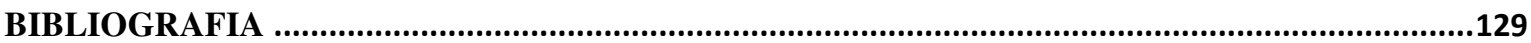

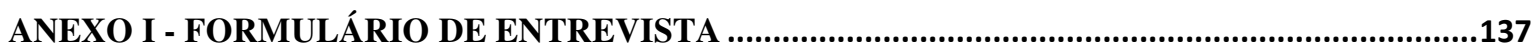

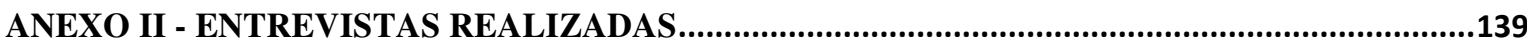

ANEXO III - MEMÓRIA DA REUNIÃO PREPARATÓRIA PARA ...............................................151

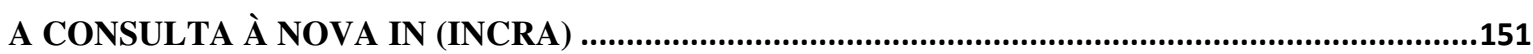

ANEXO IV - COLETÂNEA DE PROPOSTAS PRODUZIDAS …....................................................156

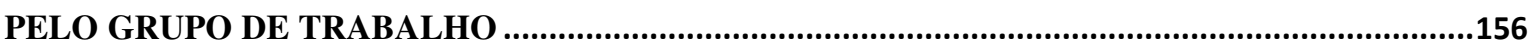

ANEXO V - INSTRUÇÃO NORMATIVA N ${ }^{\circ} 49$ (INCRA), DE 29 DE SETEMBRO DE 2008 (POSTERIORMENTE ALTERADA PELA INSTRUÇÃO NORMATIVA N ${ }^{\circ} 57$ (INCRA), DE 20 DE

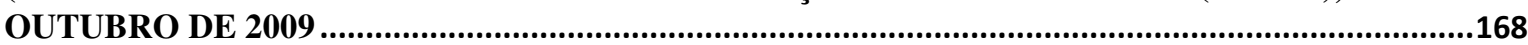

ANEXO VI - DECRETO No 5.051 (BRASIL, 2004), QUE PROMULGOU A CONVENÇÃO No 169 DA ORGANIZAÇÃO INTERNACIONAL DO TRABALHO - OIT SOBRE POVOS INDÍGENAS E TRIBAIS. 


\section{INTRODUÇÃO}

Em alguns anos de experiência profissional na Advocacia Pública, observei a recorrência de óbices internos à efetivação do planejamento administrativo, em razão de fatores gerados internamente e passíveis de encaminhamento e solução, que, ao não produzida, impacta negativamente a engrenagem estatal.

Alguns dos obstáculos para a implementação e efetivação de políticas públicas (WU, 2010, p. 107) se configuram no âmbito interno da Administração e eclodem como empecilhos à atuação estatal porque implicam choque de dois encaminhamentos de mesma natureza, vale dizer, dois movimentos para a efetivação de políticas públicas gerados como forças opostas com relevo e necessidade equiparáveis. Tal cenário denota o estabelecimento de uma litigância intragovernamental, com efeito administrativo deletério.

Neste contexto de apreciação, a litigância intragovernamental contemplada decorre do choque entre providências administrativas que visam a efetivar políticas públicas diversas e que findam se delineando contrapostas, embora geradas no mesmo componente estatal, integrando programa de governo prestigiado no processo democraticamente composto, uma questão atinente ao planejamento e sua execução.

No exercício da Advocacia Pública na Administração pude perceber que a permeabilidade desta tarefa, atuando em todos os órgãos e unidades da federação, poderia implicar a possibilidade de uma contribuição à satisfação das políticas públicas, superando a condição que alimenta o ciclo da litigância intragovernamental.

O plano de governo legitimado pelo processo democrático é alçado ao poder público em forma de programa detalhado em políticas públicas cuja efetivação será buscada. Identifica-se, nessa missão, a sobreposição de atos administrativos decorrente da ação pública não coordenada, de maneira que medidas divergentes originam-se da mesma origem estatal.

$\mathrm{Na}$ atual configuração republicana nacional o elenco dos direitos sociais encontra a guarida na Constituição Federal, ensejando o debate quanto a sua conversão em políticas públicas, como sinaliza COSTA (2015, p. 30), arrimado em observações de SARAVIA.

A divergência nem sempre é identificada ou deflagrada como tal e a contraposição tampouco é flagrante, podendo ser configurada por ações em sentidos diversos, mas gera o óbice à atuação diante do estabelecimento do impasse administrativo. 
Há necessidade de avaliação do panorama em que se configura o conflito das disposições administrativas para fazer com isto o contraponto com as possibilidades de coesão, articulação e cooperação entre os atores. A evidência da litigância intragovernamental como mecanismo de disparo das medidas para o seu encaminhamento é medida que, quanto mais preliminar, mais colabora para a possibilidade de sua composição. Em COELHO e LÚCIO (2010) estão firmados aspectos importantes para a identificação e as perspectivas adotadas por esta categoria (litigância intragovernamental), ao ser apontada, especialmente, a mediação como instrumento de gestão pública.

A litigância intragovernamental, tal como apresentada na precedente referência, evidencia a falta de compreensão do papel da Administração e do impacto deletério na paralisação de um modelo que se espera dinâmico, seja por marcos temporais, seja pela necessidade de satisfação social.

$\mathrm{Na}$ gestão de políticas públicas, a litigância intragovernamental é impasse significativo, porque implica obstáculos endógenos para a efetivação estatal, gerando alto custo social, diante da execução incompleta ou insuficiente ou da inexecução de políticas públicas, com impacto orçamentário negativo, retrocesso temporal e desgastes administrativos os mais diversos, enfim diante do estabelecimento de um processo que se retroalimenta desfavoravelmente.

A questão em pesquisa é a descrição e a análise do cenário em que este tipo de conflito surge, bem como estabelecer vínculos analíticos entre o que se denomina como litigância intragovernamental e o seu impacto no conjunto da execução das políticas públicas.

Este trabalho objetiva investigar o contexto gerador dessa litigância, identificando os aspectos que a desencadeiam, com ônus ao aparelho estatal e geradora de impactos sociais. Arrola-se como objetivo geral analisar em que medida o poder político legitimado pelo processo democrático de ascensão ao posto estatal, mediante programa de governo publicizado, pode enveredar no campo da discricionariedade administrativa, especialmente quando esta impacta na geração da litigância intragovernamental, identificada como óbice à efetivação das políticas públicas, porque tende desestruturá-las.

Como objetivos específicos estão selecionados: (1) delimitar o campo do ato administrativo discricionário e seu cenário no regime democrático; (2) avaliar a 
configuração da discricionariedade frente às disputas que se estabelecem em torno das alternativas estatais alçadas à condição de programas, ações e projetos do Estado, com efeitos na gestão das políticas públicas; (3) identificar as forças motrizes que impactam na gestão e contribuem para a configuração da litigância intragovernamental; (4) investigar a categoria interesse na configuração da litigância intragovernamental e as possibilidades de seu tratamento, em confronto com a concepção geradora das políticas públicas que se deve implementar; e (5) apresentar possíveis de formas de accountability, prerrogativa da agência, no panorama de um processo de coesão, articulação e cooperação intra-estatal.

O percurso metodológico traçado considera um encadeamento sobre concepção de Estado e democracia, em que esta teria seu requisito de validade numa concepção daquele, e as políticas públicas inserem-se com instrumentos de satisfação dos objetivos do bem comum a ser entregue como resultado.

\section{Percurso Metodológico}

A estrutura do Estado se destina a empreender as condições para que a acepção política alçada à condição de governo viabilize a concretização do bem comum, mediante a prática sequenciada de atos administrativos, efetivando compromissos previamente estabelecidos; para atos, porque estritamente vinculados normativamente, imanentes à essência burocrática, não sobejam muitos questionamentos; contudo, para outros, sobre os quais se detém esta pesquisa, implica observar a possibilidade de alguma plasticidade, passíveis da capacidade discricionária do gestor e neste campo em que se delimita a pesquisa.

Não se trata de perquirir sobre como se compõe o Estado ou a respeito de privilégio desta ou daquela concepção política prevalente, mas dar ênfase ao encadeamento lógico que vincula a capacidade de ocupação do espaço do poder e o significado ou a consequência enquanto fomento da atuação estatal.

Focando os atos administrativos de natureza discricionária, em que há espaço para a eleição de condutas administrativas, a investigação objetiva esquadrinhar os requisitos de configuração, os elementos constitutivos, sua origem, e o ambiente de sua geração, de maneira a apontar indicativos de sua pertinência com as vontades expressas no encadeamento democrático antes descrito. 
A indagação sobre a influência volitiva do gestor no momento da implementação das políticas públicas na sua acepção não apenas jurídica, mas tomando em conta a concepção política de GUILLERMO O’DONNELL (2011), para os componentes Estado, agência e democracia, e dos valores da avaliação sociológica de ZIGMUNT BAUMAN (1999), ambiciona este trabalho desenvolver o construto teórico que sinalize as categorias indispensáveis para a apreciação dos conflitos que se caracterizam na engrenagem que, embora destinada à efetividade, não raro se depara com a adversidade ou o óbice.

Também merece destaque o substrato em PIERRE BOURDIEU (1999), quanto às definições de interesse e envolvimento, considerando que em algumas oportunidades os aspectos não denotados trazem um impacto significativo, vale dizer, a litigância imanente e não deflagrada.

Desta forma, a pesquisa terá uma abordagem eminentemente qualitativa, com a análise de conteúdo clássica, partindo de uma exploração terminológica (BAUER e GASKLL, 2015), pois:

[...] (a) prontidão dos pesquisadores em questionar seus próprios pressupostos e as interpretações subsequentes de acordo com os dados, juntamente como o modo como os resultados são recebidos e por quem são recebidos, são fatores muito mais importantes para a possibilidade de uma ação emancipatória do que a escolha da técnica empregada (BAUER e GASKLL, 2015).

Fixa-se a escolha de um modelo monográfico e histórico (ECO, 2014), que considera o percurso conceitual estabelecido na bibliografia, portanto, com ênfase no trabalho de pesquisa, mais que de compilação, a ser contemporizado com pelo menos uma avaliação de caso concreto em que se logra identificar o contexto trazido pelas narrativas da literatura selecionada.

Aliás, o desenvolvimento desta pesquisa deve ser coerente com o seu despertar, pautado na experiência cotidiana de advocacia a serviço do Estado. 
O estudo de caso realizado consistiu e implicou na avaliação da atuação da Advocacia-Geral da União (AGU) ${ }^{1}$ para a identificação dos aspectos em conflitos e proposta de soluções possíveis para a configuração de obstáculos visando a efetivação de políticas públicas quanto à regularização fundiária de comunidades quilombolas, na forma do Decreto $\mathrm{n}^{\circ} 4.887$ (BRASIL, 2003) a regulamentar o art. 68 do Ato de Disposições Constitucionais Transitórias (ADCT).

O escopo do grupo de trabalho interministerial e informal coordenado pela AGU tinha, ainda, outra finalidade, relativa à mesma providência quanto à demarcação de terras indígenas, mas não se logrou a adoção de encaminhamentos factíveis quanto a esta parte de demanda recebida, o que implica que esta pesquisa esteja centrada na parte da missão interinstitucional a respeito da qual houve possibilidade de materialização dos efeitos propostos. Enriquece a narrativa a configuração de consulta pública prévia à implementação das medidas propostas pelo grupo de trabalho, logrando, ainda, o Estado brasileiro uma primeira incursão na conduta prevista na parte sexta da Convenção no 169 , da Organização Internacional do Trabalho (OIT), que prevê a realização de prévia consulta a comunidades tribais, sobre a implementação de políticas públicas que de alguma forma as impacte.

Além da pesquisa documental no processo administrativo n ${ }^{\circ}$ 00400.004590/2007-11, instaurado para a documentação dos trabalhos realizados ao longo de um ano e meio, promove-se a contextualização com o arcabouço normativo (BECKER, 1999, p. 110) que fixou o contexto do trabalho, a descrição das políticas públicas inter-relacionadas, a fixação dos pontos controvertidos e a apreciação do caso estudado, do seu contexto com a literatura multidisciplinar.

Para a melhor a apreensão do estudo de caso, aborda-se a composição de grupo de trabalho para a verificação de propostas administrativas para conciliação entre os interesses de comunidades quilombolas e indígenas em face de questões relativas à matéria ambiental, de segurança nacional e outras imbricações de políticas públicas relacionadas com a regularização fundiária dessas minorias. Investigações sobre a razão de ser do trabalho,

\footnotetext{
${ }^{1}$ A Advocacia-Geral da União é a instituição prevista no art. 131 da Constituição Federal com a competência de realizar a consultoria e o assessoramento do Poder Executivo e a representação judicial e extrajudicial dos Poderes Executivo, Legislativo e Judiciário. Disciplina suas atividades a lei orgânica, Lei Complementar ${ }^{\circ}$ 73, de 10 de fevereiro de 1993.
} 
observações sobre o seu desdobramento e sobre as consequências mediatas e imediatas das atividades desenvolvidas (FEYERABEND, 2003, p. 44).

Realizaram-se entrevistas com uma amostragem aleatória de autoridades ${ }^{2}$, gestores públicos que, ainda que por seus representantes, encaminharam as alternativas para que o resultado configurado trouxesse o relevo político do cenário da autocomposição administrativa eleita como parâmetro de pesquisa. $\mathrm{O}$ formulário adotado como propostas para as questões levadas às autoridades buscava conhecer as suas impressões sobre os trabalhos realizados pela AGU, apreciando os aspectos favoráveis e desfavoráveis dessa atuação para a pacificação da litigância que lhe deu origem. A partir das indagações apresentadas como pauta, os entrevistados ficaram à vontade para expor suas apreciações, razão pela qual não se solicitou a gravação de suas falas, exceto quanto à SubprocuradoraGeral da República Deborah Duprat, que fez questão de que sua entrevista estivesse gravada.

Vislumbrada a litigância intragovernamental como trava à efetivação e a gestão de políticas públicas, integra este trabalho a feição de uma amostra dos gestores contemporâneos ao momento republicano de identificação do conflito comentado do âmbito da Presidência da República, com a desconcentração do comando de alinhamento administrativo ao Advogado-Geral da União, que convocou a primeira conformação do grupo de trabalho interministerial e informal e apresentou os resultados conquistados em reunião entre Ministros e convocada pelo Excelentíssimo Senhor Presidente da República.

O poder político que assume o governo, para o exercício da atividade estatal tem o encargo de efetivar políticas públicas da plataforma democraticamente alçada àquela condição pela vontade popular, devendo atuar de maneira a coordenar as forças na Administração, inclusive no âmbito dos atos administrativos discricionários.

Neste exercício de atribuições institucionais, a categoria já consagrada litigância intragovernamental (COELHO e LÚCIO, 2010) configura obstáculo a ser superado,

\footnotetext{
${ }^{2}$ Autoridades entrevistadas visando obter uma amostra sobre os fatos vividos na condição pretérita de:

Advogado-Geral da União, Min. José Antônio Dias Toffoli.

Consultor-Geral da União Ronaldo Jorge Araújo Vieira Junior.

Subprocuradora-Geral da República, Coordenadora da sexta Câmara (Minorias), Deborah Duprat.

Assessora Especial do Ministro, Ministério do Desenvolvimento Agrário, Renata Leite.

Consultora Jurídica do Ministério do Desenvolvimento Agrário, Marcela Albuquerque.

Representante da Subchefia de Assuntos Jurídicos da Casa Civil da Presidência da República, Fernando Luiz Albuquerque Faria.
} 
especialmente numa perspectiva de gestão que contemple a alternativa sociotécnica, abordada por LÚCIO, DAROIT, BESSA e ABREU (2014).

Há um pressuposto de vinculação da gestão das políticas públicas com o planejamento democrático e a visão de que o planejamento na Administração pública contém matizes e complexidade próprios.

O acompanhamento e controle deve cotejar o programa de governo efetivamente eleito nos requisitos que traz O'DONNELL (2011), que vincula conceito como democracia, agência e accountability. $\mathrm{O}$ poder a ser exercido pela agência dá vida à primeira dessas categorias e possibilita a terceira como elemento de confirmação do processo, uma vez que a condição democrática viabiliza a escolha, o acompanhamento e a ratificação da proposta política traçada.

Conciliar este planejamento com as necessidades de composição, concertação e atualizações de forças políticas intra-estado, pelo dimensionamento das transformações sociais (demandas) requer um espectro que contemple o contexto líquido, fluido, que descreve BAUMAN (2014).

A relação intragovernamental pressupõe a atenção ao princípio da separação harmônica entre os poderes, a ser concatenada com a ampla participação, inclusive e especialmente do elemento social, alçado à condição de ator, em rede, como apresenta LATOUR (2012).

A quebra dos valores republicanos e democráticos, além de indiscutivelmente contraproducente ao Estado e gera perniciosos efeitos quanto à efetividade administrativa com os efeitos orçamentários e econômicos, alertados por O’DONNELL (2011). 


\section{O AMBIENTE DE GERAÇÃO DA LITIGÂNCIA INTRAGOVERNAMENTAL 1. Importantes Conceitos Preliminares: Estado, Governo, República, Democracia, Discricionariedade e Gestão de Políticas Públicas e Agência.}

Para uma abordagem a respeito das circunstâncias em que despontam a litigância intragovernamental é indispensável iniciar com uma análise quanto a alguns conceitos relacionados ao seu ambiente geracional, como Estado, república, democracia, discricionariedade administrativa, gestão de políticas públicas e agência.

Para apresentar um conceito de Estado alguns elementos costumam ser tidos em conta, como território, povo e poder político ou, dependendo da abordagem, governo. Há autores que referem, ainda, soberania, que diz respeito com o exercício de forças pelo Estado em relação ao ambiente externo. Eé a esta última a que se atribui a investidura que se outorga a faculdade/poder de atuar externamente em nome desse Estado.

DALLARI (1998, p. 30) explora esses elementos constitutivos do Estado, ratificando não haver consenso entre os estudiosos, mas deixando antever a complementaridade que pode ser obtida com a apreciação adequada das diversas contribuições. Aliás, a noção geral para tratar a litigância em muito ensina a respeito de divergência e complementaridade.

Entre esses elementos, invariavelmente, configura-se povo, em última instância o destinatário, enquanto coletividade, na ação do Estado e o responsável pelo empoderamento da força política que se investe na posição estatal. Esta reflexão comporta o relevo da categoria em elenco em relação ao objeto pesquisado.

DALLARI (1998, p. 30), sobre as formas de abordagem, destacou que:

Quanto às notas características do Estado Moderno, que muitos autores preferem denominar elementos essenciais por serem todos indispensáveis para a existência do Estado, existe uma grande diversidade de opiniões, tanto a respeito da identificação quanto do número. Assim é que SANTI ROMANO, entendendo que apenas a soberania e a territorialidade é que são peculiaridades do Estado, indica esses dois elementos. A maioria dos autores indica três elementos, embora divirjam quanto a eles.

De maneira geral, costuma-se mencionar a existência de dois elementos materiais, o território e o povo, havendo grande variedade de opiniões sobre o terceiro elemento, que muitos denominam formal. $\mathrm{O}$ mais comum 
é a identificação desse último elemento com o poder ou alguma de suas expressões, como autoridade, governo ou soberania. Para DEL VECCHIO, além do povo e do território o que existe é o vínculo jurídico, que seria, na realidade, um sistema de vínculos, pelo qual uma multidão de pessoas encontra a própria unidade na forma do direito. Já DONATO DONATI sustenta que o terceiro elemento é a pessoa estatal, dotada de capacidade para o exercício de duas soberanias: uma pessoal, exercida sobre o povo, outra territorial, sobre o território. Com GROPPALI surge a afirmação de um quarto elemento, que é a finalidade, parecendo-lhe óbvio, em primeiro lugar, que as pessoas só se integram numa ordem e vivem sob um poder, em função de um fim a atingir; em segundo lugar, o Estado, sendo dotado de ordem própria e poder também próprio, é evidente que deverá ter uma finalidade peculiar, que justifique sua existência. Por último, ATALIBA NOGUEIRA procede a um desdobramento da nota característica relativa ao poder, apontando a existência de cinco notas: o território e o povo, coincidindo com os elementos materiais; a soberania e o poder de império, que representam dois aspectos do poder, constituindo, portanto, um desdobramento do chamado elemento formal, e, além desses, a finalidade, que indica mais especificamente, como a regulação global da vida social.

Uma das modalidades de divergência acerca dos elementos constitutivos de Estado é exatamente a alternância na admissão dos componentes poder e governo ou quanto de um ou outro conceito é mais forte na delimitação política que favorece a atuação do Estado.

Apreendemos das lições expostas a delimitação de governo como o exercício do poder político na função do Estado e destacamos haver relevo nesta decomposição conceitual, a fim de que sejam cogitadas as possíveis abordagens e suas implicações para uma construção teórica.

LE GALÉS; VEZINAT (2014, p. 7-8) advertem que Estado é conceito controvertido e, sob a inspiração do modelo weberiano, consignam que o Estado ocidental é uma forma política que tem a vocação de existir permanentemente, de gerar as contradições sociais e tentar estabelecer uma ordem política, de reivindicar o exercício da autoridade e o monopólio da violência legítima. Descreve também como um ambiente de enfrentamento de diferentes grupos de interesse e um emaranhado de instituições diferenciadas, mais ou menos 
autônomas e legítimas, de pessoal, regras e organizações sobre um território com fronteiras estabelecidas.

DAHL; LINDBLOM (1971, p. 29) apresentam como conceito

O Governo é qualquer governo que sustente com êxito a reivindicação de regulamentar com exclusividade o emprego legítimo da força física para fazer cumprir suas regras dentro de determinada área territorial. O sistema político formado pelos residentes dessa área territorial e o Governo dessa área constituem o "Estado".

A teoria geral do Estado e o direito constitucional diferenciam forma de Estado e formas de governo, esclarecendo SILVA (2016, p. 104-106) que este segundo conceito guarda relação com a "maneira como se dá a instituição do poder na sociedade e como se dá a relação entre governantes e governados", ao anunciar "quem deve exercer o poder e como este se exerce", sendo tais formas: a monarquia ou a república, versão simplificada por Maquiavel a partir de noção preliminar de Aristóteles, que concebia, ainda, a aristocracia.

Este aspecto quanto à forma de se exercer a relação entre Estado e cidadão, governante e governado é relevante para o conceito democrático que se manuseia nesta pesquisa, especialmente ao se observar que participação, oposição e intervenção podem ser realizar na concomitância do exercício dos mandatos políticos.

Arrimado na lição de Ruy Barbosa, SILVA (2016, p. 105) expõe que a forma de governo republicana não apenas pressupõe a coexistência e harmonia dos três poderes (Legislativa, Executivo e Judiciário), mas a escolha dos dois primeiros mediante procedimento de escolha popular periódico e por tempo determinado e não vitalício. Estes mesmos aspectos são considerados, adiante, por O’DONNELL (2011, 2000, p. 28), ao fixar como um dos parâmetros conceituais da agência a faculdade participar ativa ou passivamente desses critérios seletivos para ocupação dos cargos políticos.

Com a peculiar objetividade contida na sua literatura, KELSEN (1945, p. 364), sumariza, sobre o Estado: 
Costuma-se classificar o poder do Estado como sendo o seu, assim, chamado, terceiro elemento. Pensa-se no Estado como um agregado de indivíduos, um povo, que vive dentro de uma certa parte delimitada da superfície da Terra e que está sujeito a certo poder: um Estado, um território, um povo, um poder. Diz-se que a soberania é a característica definidora desse poder. Embora se sustente que a unidade do poder é tão essencial quanto a unidade do território e do povo, pensa-se, não obstante, que é possível distinguir três diferentes poderes componentes do Estado: o poder legislativo, e executivo e o judiciário.

A palavra 'poder' do Estado deve ser a validade e a eficácia da ordem jurídica nacional, caso a soberania deva ser considerada uma qualidade desse poder. Porque a soberania só pode ser a qualidade de uma ordem normativa na condição de autoridade que é a fonte de obrigações e direitos. Quando, por outro lado, se fala de três poderes do Estado, o poder é compreendido como uma função do Estado, sendo distinguidas três funções do Estado.

Dado o foco de nossa abordagem, dos três elementos do Estado, a investigação recai sobre poder, explicado por KELSEN (1945) como decorrência da validade e eficácia jurídica, naturalmente porque a sua concepção está centrada exclusivamente na concepção do direito a respeito do Estado, o poder que já está constituído.

$\mathrm{Na}$ acepção que ora investigamos, é relevante observar poder ainda sob outros enfoques, especialmente sobre o que impacta para que atinja o patamar normativo, previsto por KELSEN (1945), que força atua e como se organiza esta força ou o movimento que logra alçar à condição do poder constituído da descrição kelseniana.

DAHL (1956, p. 94-95) apresenta reflexões sobre as formas de incidir a influência do poder e, após explorar quatro métodos de sua aferição, concebido como a capacidade de influenciar, pondera que todos esses métodos podem gerar deduções equivocadas, se não empregados com habilidade. Ao observar que há probabilidade de incurso em alguns erros e, no propósito de preveni-los, enumera:

1. não distinguir claramente entre participar de uma discussão, influenciar uma decisão e ser afetado pelas consequências de uma decisão. 
2. não conseguir identificar o campo ou campos em que determinado agente é considerado poderoso.

3. Não distinguir diferentes graus de poder, por exemplo, pelo equacionamento da proposição de que o poder é distribuído de maneira desigual nem sistema político, com a proposição de que o sistema é governado por uma classe dirigente.

4. confundir o poder passado e o presente de um agente com seu poder potencial, particularmente pela pressuposição de que quanto maior o recurso político a que um agente tem acesso, tanto maior deve ser o seu poder.

5. Equacionar a expectativa de poder futuro de um agente com seu poder potencial, particularmente por negligenciar as diferenças em incentivos e habilidades.

Esta questão vem a ser explorada, inclusive mediante esclarecimento gráfico, em mais de uma obra de DAHL (1976, p. 11-13, grifo do autor). Arrima-se em nomes de tradição para a análise social e política, ao encaminhar que:

Desde os tempos de Aristóteles acredita-se que uma relação política devia implicar de algum modo a autoridade, o governo, o poder. Assim, por exemplo, um dos mais importantes sociólogos modernos, o alemão Max Weber (1964-1920), afirmou que uma associação devia ser considerada política na medida em que "a implementação da sua ordem é levada a cabo continuadamente, dentro de certa área, mediante a aplicação e a ameaça da força física por parte de uma certa área, mediante a aplicação e a ameaça da força física por parte dos administradores". Portanto, embora Weber tenha acentuado o aspecto territorial da associação política, do mesmo modo como Aristóteles ele especificou que uma relação de autoridade ou de governo constituía uma das suas características essenciais.

Para dar um último exemplo, um importante cientista político contemporâneo, Harold Lasswell, define a ciência política, enquanto disciplina empírica, como "o estudo da formação do poder e da participação do poder", afirmando que um "ato político" é uma Ação executada "numa perspectiva de poder". 
As áreas de acordo e desacordo das posições de Aristóteles, Weber e Lasswell, a respeito da natureza da política, são ilustradas pela Figura 1. Aristóteles, Weber

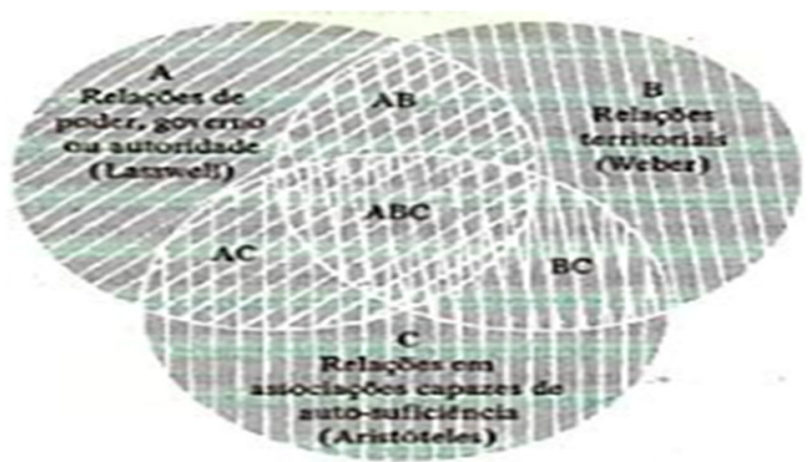

Figura 1 -

Lasswell (como quase todos os outros pensadores políticos) localizaram as relações políticas dentro do círculo A - o conjunto das relações de poder, governo ou autoridade. Para Lasswell, por definição tudo o que se encontra em A é político. Aristóteles e Weber definem como 'político' de modo a exigir uma ou mais características adicionais, indicadas pelos círculos $\mathrm{B}$ e C. Weber, por exemplo, considera que o domínio do político não abrange tudo dentro de $\mathrm{A}$ ou de $\mathrm{B}$., mas sim o que se encontra na área comum $\mathrm{AB}$. Embora Aristóteles seja menos claro a respeito deste ponto, não há dúvidas de que ele limita ainda mais o domínio do político, restringindo-o às relações em associações capazes de auto-suficiência (C). Portanto, para Aristóteles a "política" se reduziria à área ABC.

Indubitavelmente, tudo que Aristóteles e Weber chamariam de "político" seria "político" também para Laswell, mas este estenderia a abrangência da sua definição de modo a incluir algumas coisas que Weber e Aristóteles deixaram de fora: uma empresa e um sindicato, por exemplo, teriam aspectos "políticos". Vamos definir, portanto, um sistema político, audaciosamente, como qualquer estrutura de relações humanas que envolva controle, influência, poder ou autoridade, em medida significativa.

Partindo da contribuição de DAHL (1976) sobre o que é ser político, encaminha-se para a compreensão sobre poder, cogitando que este se expressa no governo, como 
continente e conteúdo; mantém-se aqui a noção do poder como o terceiro elemento do Estado.

O poder instituído se legitima pela modalidade de sua investidura no Estado, mas, uma vez admitido, encontra seu suporte no arcabouço normativo. Trata-se poder de uma composição mesclada de manifestação social, a que foi atribuída a influência política necessária a ser investida sob a forma de governo, para administrar o Estado.

A forma de investidura no poder interessa como liame para a apreciação da legitimidade, mas não é o objeto em estudo. A investigação foca na atuação do Estado, como menciona KELSEN (1945, p. 408, grifo do autor), como "uma ordem social por meio da qual indivíduos são obrigados a certa conduta.”.

E prossegue:

A liberdade possível dentro da sociedade, e especialmente dentro do Estado, não pode ser a liberdade de qualquer compromisso, pode ser apenas a de um tipo particular de compromisso. O problema da liberdade política é: como é possível estar sujeito a uma ordem social e permanecer livre? Assim, Rousseau formulou a questão cuja resposta é a democracia. Um sujeito é politicamente livre na medida em que a sua vontade individual esteja em harmonia com a vontade "coletiva" ("geral") expressa na ordem social. Tal harmonia da vontade "coletiva" com a individual é garantida apenas se a ordem social for criada pelos indivíduos cuja conduta ela regula. Ordem social significa determinação da vontade do indivíduo. A liberdade política, isto é, a liberdade sob a ordem social, é a autodeterminação do indivíduo por meio da participação na criação da ordem social. A liberdade política é liberdade, e liberdade é autonomia.

$[\ldots]$

O ideal de autodeterminação exige que a ordem social seja criada pela decisão em vigor apenas enquanto goza de aprovação de todos. A vontade coletiva (a volonté générale) deve estar constantemente de acordo com a vontade dos sujeitos (a volonté de tous). A ordem social pode ser modificada apenas com a aprovação de todos os sujeitos; e cada sujeito é obrigado pela ordem social na medida em que o consinta. Ao retirar o seu 
consentimento, cada indivíduo pode, a qualquer momento, colocar-se na sua forma pura e irrestrita, não pode haver nenhuma contradição entre a ordem social e a vontade de qualquer sujeito. Tal ordem não poderia ser "violada" por qualquer um dos sujeitos. A diferença entre um estado de anarquia, onde nenhuma ordem social é válida, e uma ordem social cuja validade se baseia no consentimento permanente de todos os sujeitos existe apenas na esfera das ideias. Na realidade social, o grau mais alto de autodeterminação política, isto é, um estado onde não é possível nenhum conflito entre a ordem social e o indivíduo, é praticamente indistinguível de um estado de anarquia. Uma ordem normativa que regula a conduta recíproca de indivíduos é completamente supérflua se todo o conflito entre a ordem e os seus sujeitos estiver excluído a priori. Apenas se tal conflito for possível apenas se a ordem permanecer válida mesmo em relação a um indivíduo que, por meio da sua conduta "viola" a ordem, é que o indivíduo pode ser considerado como estando "sujeito" à ordem. Uma ordem social genuína é incompatível com o grau máximo de autodeterminação.

Caso de faça do princípio de autodeterminação a base de uma organização social, ele deve ser restringido de algum modo. Surge, então, o problema de como limitar a autodeterminação do indivíduo apenas na medida necessária para que a sociedade em geral, e o Estado em particular, se tornem possíveis.

O equilíbrio entre a autodeterminação e o contexto de efetiva participação social, de maneira que a democracia não se materializa apenas no aspecto formal, é um relevante elemento político que vem ensejando a preocupação de há muito. Apenas para mencionar reflexões mais recentes, recorde-se TOCQUEVILLE (1989, p. 44), que se dispôs a esta investigação justamente por perceber a potencial fragilidade de uma construção democrática cuja capacidade de representação efetiva sofra percalços na composição das forças que implica a autodeterminação. Seus alertas, intensificados na reprodução de DAHL (1972, p. 62), anunciam o risco à democracia quanto a expressão de vontade desconsidera parcela social significativa em número, mas modesta na participação política.

É DAHL (1976, p. 14) quem define democracia como "sistema político em que a oportunidade de participar das decisões é compartilhada amplamente por todos os cidadãos 
adultos.". DAHL (19876, p. 27) declara que no "mundo contemporâneo, os direitos e liberdades políticos estão muito mais garantidos nos países democráticos do que nos não democráticos.”. E este mesmo autor assume que:

(...) as democracias tendem para a expansão, e não limitação, do alcance e efetividade das proteções legais aos direitos políticos primários. As privações e negações legais aos direitos que ocorrem no começo da vida de regimes democráticos tendem a ser reduzidas, ou mesmo erradicadas, e não acentuadas.

Referindo o histórico estadunidense, ao analisar a transição, da tradição privada agrária, para a formação capitalista urbana sob a forma de pessoas jurídicas, expôs que a estabelecida deliberação jurídica geradora de normas mediante o modelo de repartição econômica e política com a prevalência de interesses de uma parcela social específica suplantou padrão precedente e implantou o capitalismo, sem que houvesse a reflexão a respeito do quanto o novo modelo poderia ser mais compatível com seus compromissos com a democracia. Mas pondera que este seria um produto de um modelo econômico favorável, especialmente à construção democrática.

Por outro lado, GALBRAITH (1996, p. 8) e DAHL; LINDBLOM (1953, p. 55) analisam os fins do Estado na promoção do bem-estar social. O primeiro comenta que a perspectiva definidora desse critério depende do prisma de que o aprecia, variando entre os necessitados e os afortunados, pois para estes a configuração do bem-estar está condicionada à atuação estatal que não o onere, enquanto que, para aqueles pode se materializar quando sejam satisfeitas algumas de suas necessidades básicas. O segundo pondera que os processos tendentes ao bem-estar social tornam imprescindível o controle, eis que "é preciso controlar os demais para remover os entraves aos nossos próprios desejos e teremos de ser controlados por outros para que sejam removidos os obstáculos aos seus."

No exercício do poder, os integrantes do Estado se investem na condição de administração pública, praticando os atos através dos quais se tomam corpo as suas manifestações. Naturalmente, há de ser ter em conta que a lei como a estabilidade da estrutura tende a reproduzir o padrão pré-existente, como sinalizam autores como O’DONNELL (2011, p. 153-154): 
[...] a partir daquele momento, o estado falara a linguagem da lei. Por sua vez, a falta de coerção física direta no estabelecimento do contrato laboral foi a base da aparente igualdade das partes que, [...], precisou de tempo e de lutas para ser parcialmente corrigidas.

É importante inferir que o estado é garantia das relações capitalistas (e de outras, é claro), não dos atores sociais concretos que delas participam. No entanto, ao fazê-lo, o estado garante a reprodução da condição social dos respectivos atores. Neste sentido, a lei é a contribuição mais formalizada (e extremamente eficaz) do estado para a estabilidade e reprodução da sociedade, de suas igualdades e desigualdades. Além, disso, especialmente na democracia, a lei é a dimensão do estado que coloca suas burocracias em posição de implementar regras e decisões sancionadas por procedimentos que compõem a arquitetura legal/constitucional de um regime democrático ${ }^{3}$; isto é habitualmente efetivo e consensual porque em muitos casos é basicamente verdadeiro, embora ajude a reproduzir combinações complexas de igualdades e desigualdades.

Além disso, temos que considerar a ratificação da ordem social promovida por inúmeras decisões diárias as quais a Penélope burocrática faz um tecido que é reflexo do de ontem, e no qual a existência da ordem social dada é regularmente pressuposta. Neste sentido, falando dos funcionários estatais, Bourdieu (1996, p. 27) diz que "ao reproduzir um discurso performático sobre o estado, sob a aparência de dizer que ele é o estado, fazem com que o estado seja o que é”. Acrescento que isto inclui o apoio e a garantia que o estado oferece a múltiplas relações sociais igualitárias ou não.

Sendo este agir, de produção, interpretação e execução de normas um exercício sobre o que é público e comum, a ciência jurídica contribui com o Estado, para o estabelecimento das regras instrumentais necessárias a que as suas manifestações (do Estado) possam ser condicionadas à satisfação daquele conjunto que se faz representar (sair majoritário no

\footnotetext{
${ }^{3}$ Nota de rodapé constante no original:

Neste contexto Hunt (1993, p. 26) observa: "É importante enfatizar que as regras jurídicas não criam as relações sociais que compõem a sociedade capitalista. Mas ao estabelecê-las como princípios e fazer com que se cumpram, a lei atua não só para reforçar estas relações mas para legitimá-las em sua forma vigente" (Grifo do autor).
} 
processo eleitoral), contrapondo o poder investido com a necessidade de estar vinculado a um regime jurídico público, que não pode prestigiar apenas a representação antes formalizada pelo voto, mas a todos, conforme comentado anteriormente na citação de DI PIETRO (2016).

Tratando-se este trabalho de uma abordagem multidisciplinar, é necessário elucidar que a parte de amparo jurídico fixada considera a doutrina de KELSEN (1945, p. 626-627), para quem o campo da ciência jurídica está adstrito ao molde normativo que se constrói, uma vez efetivada a composição social e política que justificam a eleição dos legisladores. KELSEN (1934) deixa claro que o direito não é o que fundamenta a norma, mas a norma em si. Toma-se em conta nesta perspectiva o positivismo crítico, em que o contexto antecedente do aspecto normativo deve ser apreciado fora da esfera jurídica, embora com reflexos nesta:

Assim como a filosofia crítica da natureza busca, antes de mais nada, conformar-se ao postulado da objetividade, o ideal do positivismo jurídico é manter a teoria do direito positivo livre de qualquer tendência política ou, o que redunda no mesmo, de qualquer julgamento subjetivo de valor. A pureza do seu conhecimento, no sentido de indiferença política, é o seu objetivo característico. Isso significa que ele aceita a ordem jurídica conhecida sem avaliá-la como tal, e que se esforça para ser o menos tendencioso na apresentação e na interpretação do material jurídico. Ele sobretudo se recusa a apoiar quaisquer interesses políticos sob o pretexto de interpretar o Direito positivo ou de fornecer a sua necessária correção através de uma norma de Direito natural, quando, na realidade, ela está em conflito com ele. Exatamente do mesmo modo, o positivista crítico permanece consciente de quanto do conteúdo da ordem jurídica com a qual ele se ocupa é o resultado de esforços políticos. A questão quanto à origem do conteúdo da ordem jurídica positiva, quanto aos fatores que causaram esse conteúdo, está além desta cognição, que está limitada ao sistema conhecido das normas jurídicas positivas na sua qualidade de "dever ser". Caso se levante esta questão, a resposta encontra-se nestes discernimentos nem um pouco frutífero: toda a ordem jurídica que possui o grau de eficácia necessário para se tornar positiva é, mais ou menos, uma solução de compromisso entre grupos de interesses conflitantes na sua luta pelo poder, 
nas suas tendências antagônicas para determinar o conteúdo da ordem social. Esta luta por poder apresenta-se invariavelmente como uma luta por "justiça"; todos os grupos em luta usam a ideologia do "Direito natural". Eles nunca apresentam os interesses que procuram concretizar como sendo meros interesses de grupos, mas como sendo o interesse "verdadeiro", “comum", "geral”. O resultado desta luta determina o conteúdo temporário da ordem jurídica. Esta é, tão pouco quanto as suas partes componentes, a expressão do interesse geral, de um "interesse" superior "do Estado", acima dos interesses de grupo e além dos partidos políticos. Ademais, este conceito do "interesse do Estado" dissimula a ideia de um Direito natural como justificativa absoluta da ordem jurídica positiva personificada como Estado. A concepção de uma ordem que concretiza o interesse "comum" ou "geral" e constitui uma sociedade perfeitamente solidária é idêntica à utopia do Direito natural puro. O conteúdo da ordem jurídica positiva nada mais é que a conciliação de interesses conflitantes, que não deixa nenhum deles completamente satisfeito ou insatisfeito. Ele é a expressão de um equilíbrio social que se manifesta na própria eficácia da ordem jurídica, no fato de que esta é estabelecida de modo geral e não encontra nenhuma resistência séria. Neste sentido, o positivismo crítico reconhece toda ordem jurídica positiva como uma ordem de paz.

A ressalva acima impacta na compreensão de que a vontade de teor jurídico pode ser o fundamentado para a vontade do Estado, mas pressupõe observar, antes, que a vontade passou a ocupar o lugar no Estado, como norma, e que conteúdo interfere no mote para a tomada de decisão administrativa.

A feição jurídica não é mais que a forma de formalizar o que o entendimento político faz prevalecer, como um frasco vazio de conteúdo que se preenche com o conteúdo resultado da disputa, do enfrentamento e do encaminhamento conquistado, podendo ou não contar com o ingrediente social para a sua definição, em maior ou menor proporção, a depender de como se compõem as forças no cenário político que se configura.

O impacto dessa composição para a sequência do comportamento estatal é o ambiente em que se implementam as políticas públicas e no qual se apresentam os fenômenos apreendidos nesta pesquisa. 
Ainda no contexto democrático, a prevalência de uma determinada vontade, que conquista ares oficiais na administração, pela legitimidade eleitoral, não elimina uma força latente de diversos matizes, que ficou desprovida o poder legitimado.

Esta força não deixará de exercer sua pressão no ambiente social e trará reflexos no seio administrativo, com efeitos reflexos do governo e impacto no fomento da litigância, internamente no Estado, ou em face deste.

Ademais, a manifestação do Estado potencialmente é ampla, do ponto de vista da sua abrangência, pois toda a sociedade experimenta as consequências, diretas ou indiretas, da forma como se administra. Porém por estes exatos motivos, impõe-se dar limites a quem administra, a quem serve ao Estado, para que possa equilibrar a forma de exercer o poder investido em governo.

A Constituição Federal impõe princípios que traçam os parâmetros gerais do controle a que se submete a administração, sendo relevante destacar entre estes a legalidade como a diretriz basilar estatal, a fim de favorecer que o bem público buscado tende a observância de critérios objetivos fundados em normas. No arcabouço dessa necessidade de controles e ponderações, a observância da legalidade deve ser equilibrada com a possibilidade flexível de algumas escolhas limitadas.

Narrando a contribuição histórica na formação administrativa brasileira sob o enfoque jurídico, DI PIETRO (2016, p. 28) sentencia que:

Embora sob influência do direito francês e de outros direitos enquadrados no sistema de base romanística (direito italiano, alemão, espanhol, português etc.), o regime jurídico administrativo, no Brasil, também sofreu alguma influência do sistema do common law, especialmente do direito norte-americano. Mais recentemente, também vem sofrendo influência do direito comunitário europeu, emanado da União Europeia.

$[\ldots]$

Em decorrência da adoção do princípio da legalidade, o Direito Administrativo brasileiro, à semelhança de outros direitos, como o espanhol, o português, o dos países sul-americanos, colocou no direito positivo aquilo que no direito francês constituíam teorias e princípios de elaboração jurisprudencial. Aquilo que na França é alterado pela jurisdição 
administrativa no Brasil depende de alteração legislativa. E com uma agravante: as bases do Direito Administrativo estão na Constituição: as intervenções do Estado na propriedade privada, o regime estatutário do servidor público, os princípios da Administração Pública, a regra sobre responsabilidade civil do Estado, o princípio da licitação, as normas sobre orçamento e contabilidade pública, as competências normativas, a proteção do patrimônio público, os direitos e garantias do cidadão perante a Administração Pública, o controle interno, o judicial e o legislativo.

Após detalhar as influências específicas de cada fonte enumerada, DI PIETRO (2016) critica que o excessivo vínculo constitucional das regras de direito administrativo, o que, na sua avaliação, em certa medida, tendeu a obstaculizar a administração, especialmente no pertinente a sua face indireta. Esta é um significativo tema de direito administrativo, que diz respeito à constitucionalização do direito administrativo, como também aborda COSTA (2015).

Seguindo um pouco mais na perspectiva do ordenamento jurídico e especializando a abordagem exposta na citação de KELSEN (1934), de conteúdo jurídico-positivista, é pertinente explicitar que o constitucionalismo normativo ou garantista, contraposto à ideia do constitucionalismo argumentativo ou principialista, prepondera a observação do ordenamento jurídico como instrumento de satisfação dos direitos fundamentais, mecanismo com que o Estado deve atender ao desiderato do bemestar social.

FERRAJOLI (2012, p. 18-19) enuncia que tal constitucionalismo normativo ou garantista "caracteriza-se por uma normatividade mais forte, de tipo regulativo, isto é, pela tese de que a maior parte dos (ainda que não de todos) princípios constitucionais, em especial os direitos fundamentais, comporta-se como regras, uma vez que implica a existência ou impõe a introdução de regras consistentes em proibições de lesão ou obrigações de prestações que são suas respectivas garantias.”

Com esta caracterização, concebe que "o sistema jurídico e/ou uma teoria do direito que preveem - para a garantia daquilo que vem estipulado constitucionalmente como vinculante e inderrogável - a submissão (inclusive) da legislação a normas relativas à produção não só formais, relativas aos procedimentos (a quem e ao como), mas também 
materiais, relativas aos conteúdos das normas produzidas (aо que se deve decidir e ao que não se deve decidir), cuja violação gera antinomias, por comissão, ou lacunas, por omissão."

Esta contextualização tem relevo para uma abordagem seguinte, a respeito da ressalva à legalidade constitucional, prevista na possibilidade de o legislador, mas especialmente, no assunto analisado, o administrador fazer escolhas, dentro dos limites circunscritos pelo túnel normativo em que é alocado para gerir o patrimônio e satisfazer o interesse público.

O presente estudo privilegia a concepção de gestão pública, contida em LÚCIO, DAROIT, BESSA e ABREU (2014), a partir da qual se formulam estudos e se constroem debates em prol do aprimoramento da governabilidade no Estado, requisito ao desenvolvimento nacional:

Gestão pública é no contexto exposto foi entendida como um "conjunto de instrumentos, tecnologias, processos e procedimentos que viabilizam os anseios histórico, social, político e econômico da população, materializados nos preceitos constitucionais, em particular no que tange aos direitos individuais e coletivos, realizados na forma de políticas e serviços públicos".

Esta acepção está acolhida pelo Programa de Pós-Graduação em Desenvolvimento Sociedade e Cooperação Internacional (PPGDSCI), estando entre as finalidades de gerar conhecimento que viabilize a ação pública necessária, por coordenação do Estado, que se diferencia das demais instituições por realizar direitos na forma de serviços.

Nesse sentido, ao propor e implementar políticas públicas esta instituição social seria ao mesmo tempo guardiã e promotora destes direitos, papel distinto daquele exercido por outras instituições sociais nacionais e internacionais, que ao proporem serviços ou benefícios públicos não se comprometem com a realização dos direitos individuais e coletivos inscritos na Carta Magna. Em síntese, o Estado guarda em sua estrutura as organizações que operacionalizam esses direitos.

\section{Ato Administrativo Discricionário}

A menor porção da atuação estatal se concretiza no ato administrativo, espécie do gênero ato jurídico, mas que, uma vez praticado por pessoa determinada, Estado ou 
administração, como se queira configurar, adquire características específicas. Está assim descrito na lição de MEDAUAR (2015, p. 169):

Para atingir os fins a que se propõe e em virtude dos quais existe, o Estado desenvolve atividades múltiplas e ininterruptas, atuando por meio de seus agentes, os quais tomam decisões, expressas em atos que produzem efeitos jurídicos (por exemplo: reconhecem direitos, modificam direitos, extinguem direitos). Tais atos são igualmente atos jurídicos.

$[\ldots]$

$\mathrm{O}$ ato administrativo constitui, assim, um dos modos de expressão das decisões tomadas por órgãos e autoridades da Administração Pública, que produz efeitos jurídicos, em especial no sentido de reconhecer, modificar, extinguir direitos ou impor restrições e obrigações, com observância da legalidade.

DI PIETRO (2016, p. 235) comenta sobre a existência do regime jurídicoadministrativo em que se gesta o ato administrativo e adverte que esta concepção distingue este do regime de direito privado:

Nos países filiados ao sistema do common law (como Estados Unidos e Inglaterra), embora já exista o direito administrativo, nega-se a existência de um regime jurídico a que se sujeite a Administração, diverso do regime a que se submetem os particulares; o direito é comum (common law) para as suas espécies de sujeitos.

Foi, portanto, nos países filiados ao sistema europeu continental, em especial França, Itália e Alemanha, que teve origem e se desenvolveu a concepção de ato administrativo.

O'DONNELL (2011, p. 48) cita BOBBIO para descrever a recenticidade do direito público em relação ao privado. De certa maneira esta reflexão conduz a outra, quanto à necessidade de colocação frente ao coletivo, ao verificar que a tradição da defesa do interesse privado prepondera: 
É importante observar que estas formulações iniciais de agência estavam limitadas a relações na esfera privada - referiam-se a contratos, a transferência de propriedades, ao direito de família e a diversas transações comerciais. Estavam amparadas pelo direito romano que era "(U)m direito altamente individual. Promovia a liberdade de contrato sem reconhecimento da desigualdade do poder de negociação" (Stein, 1999, p. 122). Foram necessários vários séculos até que conceitos deste tipo de direito e as ideias de agência neles contidos fossem transferidos para a esfera política. Como expõe Bobbio (1989, p. 11-12):

O direito público como corpo sistemático de regras surgiu muito mais tarde que o direito privado; na verdade na etapa de formação do estado moderno... as duas categorias fundamentais do direito público europeu... foram derivadas do direito privado; o dominium, entendido como o poder patrimonial do monarca sobre o território do estado, e... o imperium que representa o poder de mando sobre os sujeitos.

Aliás, para a configuração da agência, O’DONNELL (2011, p. 57) firma a compreensão de que a sua origem provém das relações (jurídicas ou políticas) privadas, avaliando que a consequente aquisição de características coletivas, ao se exigir fosse albergada pelo Estado, se associa à constituição de conceitos equitativos no cenário político:

Como resultado desta longa e complexa trajetória histórica, a democracia contemporânea baseia-se na ideia da agência sancionada e apoiada legalmente. O governo resultante, o regime e o estado existem em referência e, em função de indivíduos que são agentes portadores de personalidade jurídica e de diversas liberdades e direitos; além disso, tal como institucionaliza a aposta inclusiva, esses indivíduos são cidadãos (dãs), fonte e justificação da autoridade e do poder de estados e governos. Insisto que esses direitos são originalmente transferências à esfera política dos direitos civis da agência que expus anteriormente. Neste sentido não é exagero afirmar que a legislação democrática contemporânea significou a constitucionalização dos direitos naturais; o agente que ficou reconhecido há muito tempo nas teorias morais e legais já comentadas, habita agora o núcleo das constituições democráticas modernas. Como disse Ferrajoli 
(1985, p. 859): “A grande inovação que deu origem ao estado de direito foi a positivação e constitucionalização destes direitos". Por sua vez, isto estabelece obrigações correlativas do estado de proteger esses direitos, tal como assinala este autor (ibid, p. 862): "A declaração constitucional dos direitos dos cidadãos determina a declaração constitucional das obrigações do estado".

O agente reconhecido na esfera pública, com a possibilidade de interferir, promove a atuação do Estado, que se manifesta na relação com o cidadão, com conduta de repercussão amplificada.

Pratica o Estado os atos de sua natureza pública, essencialmente, ainda que alguns possam ter conotação negocial, de cunho privado. Mas, como salientado anteriormente, a conceituação de Estado contém a acepção de povo, o real exercente do poder que, em perspectiva coletiva, influencia a composição do governo, o titular da condição de agência e ainda o destinatário das políticas públicas inscritas no ordenamento jurídico.

É em nome desse que se pode ou não efetivamente legitimar o poder, no momento eletivo, a título de marco temporal, e na confirmação paulatina, na implementação do programa de governo.

A carência de qualquer dos elementos constitutivos da percepção faz decair a imagem em construção. Pode subsistir uma imagem, mas será outra, não a projetada.

É MEDAUAR (2015, p. 170) quem justifica que o ato administrativo é a subclassificação do ato jurídico (termo genérico, apreendido na esfera privada, para a pública), praticado no interesse do Estado4: "Como todo ato jurídico, o ato administrativo forma-se pela conjugação de alguns elementos, os quais por sua vez, devem atender a preceitos legais para a produção de efeitos jurídicos válidos".

Com a ressalva de que os elementos configuradores do ato administrativo geram divergência na literatura jurídica nacional, MEDAUAR (2015, p. 170) passa a enumerá-los (terminologia e elenco, agente competente, objeto, forma motivo, fim e interesse público), assim como produziu DI PIETRO (2016, p. 238, grifo do autor) na transcrição seguinte:

\footnotetext{
${ }^{4} \mathrm{Na}$ literatura jurídica, a expressão estado é adotada sempre com a inicial maiúscula, assim como alguns outros vocábulos que alcançam uma conceituação própria nessa ciência. Porém, tratando-se de uma pesquisa com uma abordagem multidisciplinar, por consideração às diferenças gráficas para as demais concepções científicas, houve-se por empregam a modalidade mais geral.
} 
Para definir o ato administrativo, é necessário considerar os seguintes dados:

- $\quad$ ele constitui declaração do Estado ou de quem lhe faça as vezes; é preferível falar em declaração do que em manifestação, porque aquela compreende sempre uma exteriorização do pensamento, enquanto a manifestação não pode ser exteriorizada; o próprio silêncio pode significar manifestação de vontade e produzir efeito jurídico, em que corresponda a um ato administrativo; falando-se em Estado, abrangem-se tantos os órgãos do Poder Executivo como os dos demais Poderes, que também podem editar atos administrativo;

- $\quad$ sujeita-se a regime jurídico administrativo, pois a Administração aparece com todas as prerrogativas e restrições próprias do poder público; como isto, afastam-se os atos de direito privado praticados pelo Estado;

- produz efeitos jurídicos imediatos; com isso, distingue-se o ato administrativo da lei e afasta-se de seu conceito o regulamento que, quanto ao conteúdo, é ato normativo, mais semelhante à lei; e afastam-se também os atos não produtores de efeitos jurídicos diretos, como os atos materiais e os atos enunciativos;

- $\quad$ é sempre passível de controle judicial;

- $\quad$ sujeita-se à lei.

Prosseguindo, para demonstrar seu conceito, DI PIETRO (2016, p. 239, grifo do autor) conclui:

Com esses elementos, pode-se definir o ato administrativo como a declaração do Estado ou de quem o represente, que produz efeitos jurídicos imediatos, com observância da lei, sob regime jurídico de direito público e sujeita a controle pelo Poder Judiciário.

Alguns aspectos podem ser extraídos dessas anotações, especialmente quanto à manifestação de vontade do Estado, materializada pelo ato administrativo. Na caracterização 
de ato jurídico trazida pelo revogado Código Civil ${ }^{5}$, recorda DI PIETRO (2016), se consignavam a manifestação da vontade, a licitude e a produção de efeitos jurídicos imediatos, mesmos itens que caracterizam o ato administrativo, com a ressalva de que, quanto ao primeiro aspecto, a expressão volitiva não é livre, porque a administração "está obrigada a cumprir a vontade da lei”.

Vale dizer que a natureza do ato jurídico, quando praticado pela administração, requer o atendido de requisitos extraordinários em relação aos demais, provenientes de qualquer outra fonte. Traçada a vinculação do ato ao preceito normativo, seu aspecto volitivo não está aberto, mas fixado também na expressão consentânea com a forma do governo investido, os compromissos assumidos, o programa que o legitimou.

Em acréscimo, as três expressões seguintes merecem relevo nesta pesquisa: manifestação do Estado, manifestação de vontade, vontade do Estado.

GODOY (2012, p. 97), ancorado na lição de Rousseau, ensina que na vontade geral "busca-se caminho para a compreensão da formação da vontade na Administração num contexto histórico de afirmação das instituições democráticas".

A manifestação do Estado se operacionaliza com as práticas dos atos administrativos, menor fração de sua forma de atuar, sejam estes de natureza simples ou complexa; a expedição de um comando de trânsito ou a produção normativa de feição regulatória.

Nem sempre esta constatação fica bem clara para administração e administrados, momento em que discricionariedade pode implicar risco ao Estado democrático de direito, implicando risco para ambos flancos.

Insere-se na perspectiva desta pesquisa evidenciar este fenômeno, a fim de aproximar a efetiva conceituação e os limites da abordagem discricionária, ou quanto à vontade travestida na decisão administrativa.

A vontade do Estado deve atender a essa vontade geral decorrente do processo democrático, construção sujeita a forma específica e correspondentes controles. É desafiada por vontades particulares ou por vontades corporativas, conforme delineamento de GODOY (2012, p. 99, grifo do autor), que orienta ainda:

\footnotetext{
${ }^{5}$ art. 81, da Lei $n^{\circ} 3.071$, de $1^{\circ}$ de janeiro de 1916, revogado pela Lei ${ }^{\circ} 10.406$, de 10 de janeiro de 2002.
} 
Esta última, a vontade geral, resulta de decisão coletiva que tem por objetivo atender a necessidades também coletivas, abstraindo-se vontade pessoais, localizadas e setoriais. E porque a natureza dita apenas interesses e vontades pessoais, a sociedade civil deve centrar-se numa convenção, qualificadora da imaginária vontade geral, concentrada num soberano, cuja obediência seria a medida exata da liberdade.

A vontade geral é aquela que compartilhamos como cidadãos. Estreitando as diferenças entre fatos e fantasias. Rousseau indicou mecanismos para combate da natureza egoísta da sociedade, revelando encantador otimismo para com a natureza humana, exigindo reformas radicais como o objetivo de se alcançar a igualdade entre as pessoas.

E prossegue GODOY (2012, p. 100, grifo do autor), ao conectar os conceitos vontade e democracia, para explicar que:

[...] o sistema presidencialista, num contexto democrático, pode qualificar uma possível vontade geral, identificada como uma vontade de governo. Há necessidade de que se conte com mecanismos efetivos de controle, de monitoramento e da articulação das várias vontades que se revelam num mesmo Governo, numa sociedade pluralista e democrática. É necessária a fixação de um espaço facilitador de consenso, como condição prévia para o desdobramento das discussões.

O problema não estaria, necessariamente, na multiplicação de vontades. A discussão estaria na necessidade que se tenha um mecanismo eficiente para discussão e fixação de vontade convergente. Caso contrário, o que se tem, insiste-se, é a técnica do impasse, por intermédio da qual o Executivo não se movimenta.

Sobre estas expressões, há necessidade de reflexão com mais vagar, e a respeito disto se discorrerá mais adiante, eis que o cerne da questão neste ponto é investigar a atuação do Estado, como este se configura; é comentar o primeiro aspecto, manifestação do Estado, travestida no ato administrativo. 
Aqui concentra-se a ideia de que a prática do ato administrativo expressa a atuação do Estado, como dito acima, desde o movimento mais singelo, de recebimento de um expediente no setor de protocolo, mediante a emissão do recibo que identifica o servidor responsável, até o julgamento de recurso em face de decisão que houve por demitir servidor público, demonstrada a prática da conduta reprimível com tal sanção. Porém, a força motriz desses atos deve ter seu viés republicano, atento à vontade principal, guiado pelos preceitos públicos, revestido da consideração cênica democrática.

Naturalmente, é importante caracterizar completamente a manifestação do Estado, de maneira que, uma vez operada, seja passível de reconhecimento, afastando de outro conceito. O'DONNELL (2011, p. 143-144) adverte que a atuação estatal implica a consubstanciação de determinados requisitos:

A decisão estatal tomada por determinado indivíduo só é imputada como ato estatal porque certas regras definem que tal ato realizado por tal indivíduo, tendo cumprido certos requisitos prescritos legalmente, qualifica-se como uma decisão 'oficial' (i.e. estatal). Como disse Hosle (2004, p. 498):

'O estado existe como estrutura social e legal apenas na medida em que certas pessoas realizam certos atos - embora elas realizem estes atos com a consciência de que estão contribuindo para uma ordem que, de acordo com seu significado último, vai além de sua própria existência e está legalmente estruturada. As pessoas jurídicas não podem ser concebidas como ficções ou como entidades realmente independentes dos seres humanos que as sustentam - são esquemas de imputação e, como tais, podem atualizar-se através do comportamento concreto de indivíduos reais, por um lado, e por outro fazem com que seja possível avaliar de maneira precisa seu comportamento. $\mathrm{O}$ fato de o estado ter certos direitos significa que certas pessoas têm direitos equivalentes, não como pessoas privadas mas sim como pessoas que exercem certo cargo.'

O 'esquema da imputação' é a cadeia de autorizações outorgadas legalmente que criam a unidade real, embora subjacente e pouco visível, do estado. A dimensão jurídico/legal do estado lhe outorga sua unidade, é o fio que une suas partes. Por outro lado, contra interpretações 
excessivamente legalistas, esta dimensão não é todo o estado; é a parte que coloca diante de nós indivíduos que têm a vantagem de ter certa categoria de suas atividades definida legalmente como parte e emanação da autoridade do estado dando a origem a seus respectivos poderes.

\section{$[\ldots]$}

Em resumo, o estado inclui, em uma de suas dimensões constitutivas, uma cascata de autorizações sancionadas legalmente: isto é o que dá ao estado sua unidade empírica conceitual. Todo funcionário do estado é tal porque foi designado (ou, em alguns casos eleito(a)) para esse papel por meio de um procedimentos formalizado juridicamente; por sua vez, este procedimento outorgou-lhe o direito de realizar uma designação a outros indivíduos localizados em uma posição hierarquicamente inferior na estrutura burocrática do estado. Este indivíduo, por sua vez, deve seu próprio papel a um processo semelhante, naquilo que, muitas vezes, é uma longa cadeia de autorizações conferidas legalmente. Esta cadeia é contínua, independentemente do caráter unitário ou federal do estado, já que as autorizações conferidas nos estados federais pelas autoridades locais se originam da estrutura constitucional geral daquele estado. Além disso, devemos observar que esta cascata é uma característica única do estado moderno: é a manifestação de sua dimensão legal e a consequência das diversas expropriações que, [...] foram parte do surgimento do mesmo.

Há relevo em recordar a anterior referência já feita ao conceito de Estado, demonstrando que a manifestação expressa tem esta natureza diante da identificação da pessoa (jurídica) que o pratica.

Em síntese, o ato administrativo define-se como tal porque provém de uma atuação do Estado e este deve ser reconhecido para que também o ato assim seja definido. A expressão do Estado ocorre nas funções executiva, legislativa e jurisdicional, mas o objeto desta investigação centra-se na função administrativa predominante e comum, materializada como atividade meio dos Poderes Judiciário e Legislativo e como recorrente do Poder Executivo. Como sintetiza MEDAUAR (2015, p. 62): 
[...] permanece em cada conjunto orgânico um núcleo de atividades típicas que possibilita caracterizá-lo e diferenciá-lo dos demais conjuntos, sob o aspecto da atividade em si e do modo como é realizada.

Um programa de governo é detalhado em políticas públicas, que se materializam em ações condizentes com as metas que se estabelecem, desdobrando-se na prática de atos administrativo unitários ou complexos, simples ou compostos, mas em geral encadeados, como uma rede de conexões ou interligações.

É mediante a prática dos atos administrativos que se materializam as entregas atinentes às políticas públicas em seus desdobramentos, como por exemplo, a entrega do medicamento, a matrícula escolar, o serviço de limpeza urbana diário, entre outros.

Ao externar a vontade administrativa, é dever do administrador público em qualquer Poder a observância do princípio da legalidade (MEDAUAR, 2015, p. 62):

O sentido do princípio da legalidade não se exaure com o significado de habilitação legal. Este deve ser combinado com o primeiro significado, com o sentido de ser vedado à Administração editar atos ou tomar medidas contrárias às normas do ordenamento. A Administração, no desempenho de suas atividades, tem o dever de respeitar todas as normas do ordenamento.

A obrigação de atuar de acordo com as normas induz a administração a exercer o poder vinculado, porque a vinculação é legal. Em contra-face ao poder vinculado, vislumbrase o poder discricionário, como "faculdade conferida à autoridade administrativa diante certa circunstância, escolher uma entre várias soluções possíveis." (MEDAUAR, 2015, p. 135).

Destaque-se que atuar sob certa circunstância não implica deliberar livremente ou em contraposição ao contexto ou, como a imagem já trazida, à rede de interconexões dos atos administrativos, porque o desborde discricionário pode induzir a negação daquele contexto.

A literatura de direito administrativo tece considerações sobre a natureza da discricionariedade no uso corrente como a prática voluntariosa e arbitrária, o que deve ser dissociado da atual concepção administrativa, que se delineia pelo traço do Estado de direito, 
em que, forçosamente a totalidade da atuação do gestor público não está nem poderia, efetivamente, estar tratada em norma expressa, ainda que diante na concepção que o princípio da legalidade pressupõe a conduta de acordo com a norma e não integralmente detalhada na lei.

A discricionariedade constitui campo de razoável espectro, não obstante limites claramente definidos e a circulação em seu interior atende a critérios previstos de maneira a que ao Estado e ao cidadão não se gerem compromissos aquém ou além da capacidade de sua implementação (MEDAUAR, 2015, p. 137):

A autoridade, ao exercer o poder discricionário, deve atender ao interesse público referente à competência que lhe foi conferida, e, por isso, a escolha que realiza é finalística. Evidente que há diversos interesses no contexto social, o que leva à ponderação comparativa de todos ante aquele atinente a sua competência. Por isso, um setor da doutrina menciona a relevância do conhecimento fiel e completo dos fatos relacionados à decisão a ser tomada e da consideração de todos os interesses envolvidos, atribuindo a cada um o peso justo.

Contudo, ainda que aparentemente a norma legal expressa não indique o caminho a percorrer, está o administrador sob a égide de preceitos basilares, princípios de alçada constitucional, que também discorre sobre os direitos fundamentais, comuns aos cidadãos, aos que atendem à condição do elemento povo, componente da definição de Estado.

Com efeito, a discricionariedade da administração é, invariavelmente, relativa, porque condicionada a uma apresentação condizente com os princípios constitucionais que a regem e, ainda ao programa de governo alçado à condição estatal prevalente. A consonância entre estes dois parâmetros é um exercício intelectivo que condiciona o gestor à atuação efetiva.

A combinação em relevo tende a estabelecer a atuação estatal, ainda que discricionária, legítima. Aliás, é mais preciso afirmar que a atuação discricionária é sempre legítima e que o resvalo deste crivo leva a incorrer no arbítrio, este ilegítimo proceder administrativo, com o forte potencial de gerar o conflito (nascedouro da litigância intragovernamental), porque descuida do equilíbrio que integra a discricionariedade 
(legítima), descrita por FREITAS (2007, p. 20, grifo do autor), como o instrumento do direito fundamental à boa administração pública:

É que o estado da discricionariedade legítima, na perspectiva adotada, consagra e concretiza o direito fundamental à boa administração pública, que pode ser assim compreendido: trata-se do direito fundamental à administração pública eficiente e eficaz, proporcional cumpridora de seus deveres, com transparência, motivação, imparcialidade e respeito à moralidade, à participação social e à plena responsabilidade por suas condutas omissivas e comissivas. A tal direito corresponde o dever de a administração pública observar, nas relações administrativas, a cogência da totalidade dos princípios constitucionais que a regem.

Observado de maneira atenta, o direito fundamental à boa administração é um lídimo plexo de direitos encartados nessa síntese, ou seja, o somatório de direitos encartados nessa síntese, ou seja, o somatório de direitos subjetivos públicos. No conceito proposto abrigam-se, entre outros, os seguintes direitos:

(a) o direito à administração pública transparente, que implica evitar a opacidade (princípio da publicidade), salvo nos casos em que o sigilo se apresentar justificável, e ainda assim, não-definitivamente, com especial ênfase às informações inteligíveis sobre a execução orçamentária;

(b) o direito à administração pública dialógica, com as garantias do contraditório e da ampla defesa - é dizer, respeitadora do devido processo (inclusive com duração razoável), o que implica o dever de motivação consistente e proporcional;

(c) o direito à administração pública imparcial, isto é, aquela que não pratica a discriminação negativa de qualquer natureza;

(d) o direito à administração pública proba, o que veda condutas éticas não-universalizáveis;

(e) o direito à administração pública respeitadora da legalidade temperada e sem "absolutização" irrefletida das regras, de modo que toda e qualquer competência supõe habilitação legislativa; 
(f) o direito à administração pública eficiente e eficaz, além de econômica e teleologicamente responsável, redutora dos conflitos intertemporais, que só fazem aumentar os chamados custos de transação.

Tais direitos não excluem outros, pois se cuida de "standard mínimo. Por certo, tais direitos precisam ser tutelados em bloco, do desiderato de que a discricionariedade não conspire letalmente contra o aludido direito fundamental. Em outras palavras: as escolhas administrativas serão legítimas se-e somente se-forem sistematicamente eficazes, motivadas, proporcionais, transparentes, imparciais, respeitadoras da participação social, da moralidade e da plena responsabilidade.

Em suas conclusões na obra de referência, FREITAS (2007, p. 126) é contundente:

A clivagem entre atos vinculados e discricionários reside na maior ou menor intensidade de vinculação ao princípio da legalidade (por isso não se admite, por exemplo, revogar ato vinculado), mais que na suposta inexistência de liberdade do agente na consecução dos atos administrativos. O bom administrador público, nos atos discricionários, emite juízos decisórios de valor, no intuito de imprimir crescente concretização aos vetores constitucionais; ao passo que, ao praticar atos vinculados (reitere-se a impossibilidade da vinculação absoluta), emite juízos, mas o estritamente necessário à subordinação ao sistema.

Enfim, a atuação administrativa, via de regra, há de se adequar à vinculação legal, compreendida como de acordo com a lei, ainda que mediante regramento de mais reduzida hierarquia.

Como já é recorrente, o princípio da legalidade implica estar de acordo com a lei, mas não, necessariamente, estar previsto integral e expressamente na lei. Hipóteses há em que não se exige a previsão legal estrita. Pode o ato estar previsto em norma de inferior hierarquia, desde que esteja adequado ao que se define no padrão legal.

Por outro lado, em casos autorizados na sistemática administrativa e conforme com a legalidade, pode o gestor fazer escolhas, mas estas são concebidas em contexto delimitado pelos parâmetros da atuação que prestigie princípios, preceitos e conceitos. 
A própria Constituição Federal estabelece, em seu art. 37, princípios que delimitam as escolhas administrativas, ainda que sob a concepção discricionária.

A álea discricionária possibilita a flexibilidade administrativa, onde o ordenamento jurídico entendeu que mais se observaria os princípios regentes da administração se coubesse ao gestor público mais de uma alternativa para a sua tomada de decisão.

Exemplificando, na alta administração, as políticas públicas assim definidas emanaram de processo legítimo de assunção do poder estatal mediante o compromisso de seu atendimento, ficando a discricionariedade firmada no espectro das possibilidades que observe esta construção democrática. As escolhas hão de atentar à Carta política e, consequentemente, a esta composição republicana em que a seleção das condições para a atuação preserve a vontade impressa pelo cidadão.

Naturalmente, como processo de construção democrática envolve expressão de maioria e equilíbrio de forças frente ao efeito volitivo de uma minoria disposta a efetivar a transparência e a prestação de contas, não se pode conceber a singela hegemonia como o trilhar da gestão.

O campo de disputas no cenário democrático não se encerra com o atingimento do locus estatal pelo poder político majoritário. É este apenas um marco na cronologia de governo.

Infundindo o norte conceitual das atividades consultivas da Advocacia-Geral da União, no curso de sua gestão o então Consultor-Geral da União Ronaldo Jorge Araujo Vieira Junior, na qualidade de dirigente da Instituição e coordenador dos trabalhos de assessoramento e consultoria jurídica no âmbito da administração federal, edificou, em artigo publicado na Revista da AGU, relevantes parâmetros para o desempenho das atribuições nesta seara, especialmente mediante abordagem quanto à relação entre advocacia de Estado e políticas públicas.

Relevo deve ser dado ao cotejo entre o conteúdo declinado pelo autor e a vigência de seu exercício no cargo antes descrito. Portanto, não apenas declinava quanto a uma concepção, mas dava o norte das funções sob sua supervisão.

A conformação republicana dos direitos e garantias constitucionais implica uma composição administrativa ampla, contínua e multifacetada, assim descrita por VIEIRA JUNIOR (2009, p. 27): 
VI.2. Os Poderes e as Políticas Públicas

95. O Poder Executivo é o Poder legitimado constitucionalmente a tomar a iniciativa de formular e implementar políticas.

96. Possui competência privativa de encaminhar matérias orçamentárias que instrumentalizam as políticas públicas e os programas de governo.

97. Há, também, como visto, a necessidade de promover a densificação das políticas públicas que tenham sede constitucional.

98. As políticas públicas são, então, a materialização das promessas e propostas de campanha vitoriosas na eleição e que representam uma dada concepção de organização do Estado e da sociedade.

99. Trata-se de movimento legítimo e que representa a essência do regime democrático e republicano fundado em eleições livres e na alternância do poder.

100. Ao Poder Executivo também é atribuído o poder/dever de dispor sobre a organização e funcionamento da administração pública, quando não implicar em aumento de despesa, nem criação ou extinção de órgãos públicos, de modo a tornar efetivas as políticas públicas.

101. O Poder Legislativo, por seu turno, possui ampla possibilidade de manifestação e deliberação, ressalvados limites constitucionais significativos, como vedação de aumento de despesas em projetos de iniciativa exclusiva do Presidente da República.

102. Esses limites ao Poder Legislativo aplicam-se quando ocorrem as hipóteses constitucionais de iniciativa legislativa privativa do Presidente da República, como a criação de cargos, funções ou empregos públicos; a criação ou extinção de Ministérios e de órgãos e entidades da Administração Pública.

103. Atua, ainda, o Poder Legislativo no controle e fiscalização das políticas públicas com o auxílio do Tribunal de Contas da União.

104. O Poder Judiciário promove o controle de constitucionalidade e de legalidade dos componentes das políticas públicas.

105. Há, inclusive, a possibilidade eventual de controle de mérito, nos casos de legislação desarrazoada. Segundo o Supremo Tribunal Federal, o 
poder de legislar não é ilimitado, há que se preservar o mínimo intangível assegurador da dignidade do ser humano.

106. A possibilidade de controle do mérito ocorre, também, quando os Poderes Executivo e Legislativo demitem-se da obrigação de tornar efetivos direitos constitucionais.

107. A atuação do Poder Judiciário também tem sido considerada possível quando políticas públicas são previstas na própria Constituição, partindose da premissa de que a norma programática não pode ser vista como promessa constitucional inconsequente.

E conclui o ex-Consultor-Geral da União ${ }^{6}$, refletindo sobre os desafios a cargo da advocacia consultiva no Estado, no âmbito do Estado democrático de direito:

\section{CONCLUSÃO}

É uma agenda monumental a ser enfrentada, que impõe uma constante reflexão sobre os reais motivos da existência dos órgãos de assessoramento jurídico.

Tentou-se, neste artigo, ainda que de forma precária e tangencial, demonstrar que a verdadeira missão da advocacia pública consultiva é conferir segurança jurídica às políticas públicas do Governo, já que essas são a materialização das promessas de campanha, escolhidas pela população, pelo voto direto, no âmbito do Estado Democrático de Direito. Conferir segurança jurídica significa, tendo como fundamento o ordenamento jurídico-constitucional, apontar as melhores alternativas, ou as alternativas possíveis, que levarão à concretização dos direitos fundamentais assegurados constitucionalmente a todos os cidadãos brasileiros.

Mas há um ponto de relevo a ser tomado em conta: o exercício volitivo e quem o exerce, para qual finalidade, à medida em que este é um aspecto que impacta, como se observará adiante, com a avaliação dos aspectos que configuram a litigância intragovernamental.

${ }^{6}$ Ibid. 
O cenário de disputas não se última nessa assunção do poder e cabe ser exercitado no cotidiano administrativo. Exemplo deste empenho, são os registros a respeito das atividades desenvolvidas no âmbito da Consultoria-Geral da União, relatadas pelo também ex-Consultor-Geral da União Arnaldo Sampaio de Moraes Godoy (2014, p. 44).

\section{A Configuração da Litigância Intragovernamental}

O conceito litigância intragovernamental, prestigiado neste trabalho, tem origem dissertação precedente, da Mestra Meire Lúcia Gomes Monteiro Coelho, então Procuradora Federal (atualmente inativa e dedicada às atividades docentes junto à Universidade de Brasília) que, assim como esta autora, desenvolveu atividades funcionais junto à Câmara de Conciliação e Arbitragem da Administração Federal, departamento da Consultoria-Geral da União (CGU), Órgão de Direção Superior da AGU.

Sob a orientação da Professora Doutora Magda de Lima Lúcio, iniciou o vínculo burocracia/academia, investigando o fenômeno e as possibilidades de resolução dos conflitos administrativos, experiência que deu fundamento também para o artigo científico, que, assim como a mencionada dissertação, ensejam marcos teóricos de onde parte esta pesquisa.

O Estado enfrenta embates perante ao particular ou internamente, na sua estrutura, entre órgãos da Administração direta ou entre entidades da Administração indireta ou, ainda, entre estes e aqueles. Em que pese a Lei $n^{\circ} 13.140$ (BRASIL, 2015), que disciplina a autocomposição dos conflitos pela Administração, ser mais ampla do que este objeto de estudo, eis que contempla a relação jurídica também face ao particular, há que se considerar aqui apenas o litígio administrativo endógeno, avaliando os aspectos de sua contextualização, assim definido, como litigância intragovernamental, tal como vem sendo construído no campo Teórico sobre o qual se discorre nesta seção.

Observe-se que ainda pende de expedição o previsto decreto que regulamentará a descrita lei, de maneira a impulsionar a sua efetividade e remover a pedra que a mantém à condição análoga à de norma programática.

$\mathrm{Na}$ presente abordagem, consigna-se uma singela, pontual mas significativa diferença em relação à concepção da mencionada categoria impressa por GODOY (2012, p. 10 e 106, grifo do autor), considerando que a sua contextualização ficou assim delineada: 
Não se especula com a presunção de que a litigância intragovernamental decorreria de disputas, animosidades e visões distintas de vários Ministros, o que seria abstratamente. Possível no chamado presidencialismo de coalizão, dado que alianças partidárias trariam para dentro do Governo políticos com percepções distintas e conflitantes, em relação aos assuntos demandados pela Presidência.

$\mathrm{Na}$ possibilidade do presidencialismo de articulação institucional a preocupação não é com o relacionamento entre Presidente e os partidos aliados, o que é justamente o eixo problemático do presidencialismo de coalizão. A apreensão de um presidencialismo de articulação institucional se dá mais precisamente com o relacionamento entre o Presidente e todo o Executivo, cujas divergências necessitam de canal próprio para composição, no contexto da própria Administração. O trabalho pretende discutir o papel dessa animosidade que revela o Estado em suas contradições e querelas internas.

Em outras palavras, no presidencialismo de coalizão o problema está no relacionamento entre o Executivo e o Legislativo. No presidencialismo de articulação institucional o problema está no relacionamento entre o Executivo e o próprio Executivo.

\section{$[\ldots]$}

A divergência que se pretende mapear é a que se tem internamente no Executivo e não a que qualifica o pluralismo de uma sociedade democrática. [...] Preocupa-se aqui com a avaliação da litigância interna na Administração, o que revela necessidade de fixação de critérios de diretrizes, eficiência eficácia, efetividade, metas, método, tarefas. Por isso, utiliza-se de amostragem que pode revelar a intensidade como a Administração litiga internamente. É esse o núcleo do problema, que exige um referencial teórico para a compreensão dos dados coletados e apresentados.

Nesse sentido, a estrutura do trabalho entra-se na concepção de vontade corporativa, em oposição a uma vontade geral, como enunciado em Rousseau, bem como numa percepção de unidade governamental, como 
cogitado pelos autores dos Artigos Federalistas ${ }^{7}$. No núcleo, estuda-se o presidencialismo.

Como se observa, o cerne da apreciação em relevo, configurada no âmbito da Teoria Geral do Estado, tem como foco o presidencialismo, embora centrada também na litigância interna administração.

A presente investigação, de outra parte, na linha traçada na categoria cunhada por LÚCIO e COELHO (2010) objetiva analisar o surgimento da litigância com impacto na gestão administrativa e enquanto óbice à gestão das políticas públicas.

Há, também, um marco temporal, concernente ao momento da implementação das políticas públicas (HOWLETT, 2013, p. 16), quando podem ser percebidos óbices das mais diversas ordens para que se efetive o planejado.

Em tópico precedente, quando se apresentou a contextualização conceitual desta investigação, sinalizou-se que se trata de avaliar a ação do Estado, decorrência de uma manifestação de vontade popular que se investe no poder mediante a legítima determinação do cumprimento de uma agenda detalhada em programas e políticas públicas, para cuja execução o aparato da administração pública se faz indispensável, até por ser esta a sua função essencial. É este o mecanismo em que opera a gestão, servindo ao atendimento dos fins colimados pela agência.

Isto não é, contudo, o ponto final do processo, mas o de partida para o fenômeno que observamos, vale dizer, sobre como se comporta a administração pública no implemento das deliberações democráticas. Também convém ponderar se a colheita de tais deliberações se encerra com a investidura dos gestores em seus postos, ou sobre a possibilidade de que, no acompanhamento desse processo de efetivação a participação também se opera.

Não se trata, simplesmente de por em prática o que ficou planejado, projetado, mas instrumentalizar o que ficou definido ao conciliar as diversas perspectivas nada lineares, os processos decisórios não são estanques e muito menos os fatos.

\footnotetext{
${ }^{7}$ A obra, com esta denominação, aborda a clássica coletânea de artigos escritos pelos responsáveis pela construção da república estadunidense, James Madison, Alexander Hamilton e John Jay. Nas, palavras de Thomas Jefferson, o "melhor comentário jamais escrito sobre princípios de governo."
} 
O assunto não é recente nem a solução mágica, é construção permanente, ao mesmo tempo antiga e complexa. Para enfrentá-lo, uma reflexão de DAHL (1976, p. 5) bem exprime esta dinâmica e demonstra que o desafio é efetivo, se cogitada a variável tempo:

De fato, as instituições políticas se modificam. A democracia moderna simplesmente não equivale ao sistema político de Atenas ou da República romana. Por outro lado, até certo ponto o estudo da política é cumulativo. $\mathrm{Na}$ verdade, em certos setores o conhecimento acumulado cresce quase anualmente. Se alguém me perguntasse: "Como posso aprender a respeito do tipo de gente que participa da atividade política, e seus motivos?", meu conselho seria o de começar com os estudos mais recentes, e estudar o tema deste ponto para trás. Estou convencido de que a leitura de Aristóteles ou de Rousseau não o ajudaria muito.

De outra parte, na apreciação do objeto, é válido o alerta de SIMMEL (1917, p. 13):

Quando vemos um objeto tridimensional que esteja a dois, cinco, dez metros distante, temos uma imagem diferente a cada vez, e, a cada vez, uma imagem que estará 'correta' a seu modo e somente nesse modo, e é também no escopo desse modo que se cria margem para equívocos.

Sob o ponto de análise desta pesquisa entende-se que a categoria litigância intragovernamental traz à luz elementos importantes para identificar a existência de óbice à efetivação de medidas administrativas, pela ocorrência de uma força aparentemente equiparada, proveniente de outra fonte administrativa, igualmente legítima; configura-se numa atuação estatal que enfrenta o contraponto com outra ou outras, todas colimando objetivos de interesse administrativo díspares.

Esta circunstância impede o progresso da ação e atrai um desgaste para a função pública, desfocando a atuação e irrompendo a divergência, o conflito, de maneira que uma terceira iniciativa necessita ser adotada para que o obstáculo dissipado, a fim de haver a fluidez dos processos estatais. 
Indispensável comentar que a configuração do conflito é mais amplo que a detecção da litigância intragovernamental que abordamos, pois o pressuposto é que as medidas administrativas contrapostas gozam da comum condição de consequência da vontade estatal manifesta, abstraindo de interesses outros eventualmente advogados como públicos. O recorte é essencial para que se compreenda que este registro diz respeito ao panorama da litigância que impede a concretude dos fins públicos, consequentemente gerando prejuízos à realização da vontade estatal.

Interpreta-se que a vontade estatal não está configurada quando um dos geradores da litigância intragovernamental defende interesses outros que não os fins públicos, circunstância em que cuida do litígio genérico, contraposto em face do Estado.

Esta ressalva é relevante como recorte epistêmico, especialmente quando se considera que a litigância intragovernamental é conceito que enfrenta a sobreposição de duas vontades ínsitas no Estado e igualmente legítimas na perspectiva da materialização das políticas públicas.

O ponto de colisão, gerador da litigância intragovernamental, implica a confluência de atos administrativos voltados à satisfação de interesses da Administração ao materializar políticas públicas que decorrem da aprovação e da fixação de um programa de governo, alçado à condição de poder estatal.

Adiante será abordada a conformação da discricionariedade e a alocação desta, face a outros conceitos como democracia, república, gestão de políticas públicas e agência.

Para este momento, é relevante estabelecer o foco deste discurso, circunscrevendo-o à configuração da lide interna da Administração e em prol de atendimento das políticas públicas. Este limite restringe a unidade de pesquisa mas impacta fortemente nos elementos conceituais. Aproxima a satisfação do interesse público com a sua indisponibilidade.

De um lado, a litigância intragovernamental é óbice para a concretude das políticas públicas e, de outro, não há possibilidade de o gestor se deixar render, porque indisponível a missão (pública) que lhe é conferida.

Considerando que o fim do Estado é a satisfação do bem comum ${ }^{8}$ e a materialização dos direitos fundamentais consignados na sua Carta política, a litigância que impacta na

\footnotetext{
${ }^{8}$ No início do capítulo VII da Política, Aristóteles diz que "o bem em política é a justiça, ou seja, o interesse comum". (MILOVIC, 2017, p. 31)
} 
consecução desses objetivos. Também a litigância intragovernamental promove desgastes no mecanismo administrativo, na gestão, no orçamento, nas relações interpessoais e no atendimento dos fins do Estado, implicando cursos sociais, pelo não atendimento necessário das demandas.

Porém, tais efeitos apenas são percebidos quando a litigância é alçada à condição de extremo óbice. A gestão do risco da litigância intragovernamental implica circunferência mais ampla, porque interfere no gerenciamento das condições do conflito não denotado, que danifica o tecido estatal sem efeitos aparentes imediatos, mas com significativos danos estruturais, eis que a sua posterior e efetiva configuração pode expor um espectro de amplitude de difícil gerenciamento.

Hipóteses há em que esta resistência é configurada de uma forma sub-reptícia, mediante os empecilhos silenciosos mas de significativo impacto, que restringem a atuação efetiva. São entraves a título de exigência burocrática, obstáculos de formalidade dispensável ou mera protelação.

Identificar e reconhecer, para encaminhar, é tão relevante quanto resolver, à medida em que a fonte geradora do conflito também é o indicativo para esta última etapa, vale dizer, há uma estreita vinculação entre a causa e a solução do conflito.

A litigância pode ser observada em qualquer momento do ciclo das políticas públicas, com implicações diferentes para cada contexto, mas os efeitos são invariavelmente a procrastinação ou a inviabilização das políticas públicas.

Traz considerável impacto na gestão pública, ensejando a matéria abordagem de cunho inter ou multidisciplinar, porque a perspectiva meramente jurídica, política, sociológica ou econômica não responde, com exclusividade, a problemática e não encaminha a solução.

A forma de lidar com sua configuração da litigância intragovernamental ainda é aleatória. Denota uma expressão de vontade para além do contexto administrativo envolvido. Poderia se dizer que há traços de cultura, com impacto na gestão.

No universo jurídico, que assessora a tomada de decisão administrativa, salvo raras exceções, a tradição para o litígio ou para a terceirização da solução favorece este efeito que se amplifica no meio gerencial. A cultura do litígio pode se configurar na prática de determinados atos, ainda que supondo o questionamento, mas adiando a solução para quando 
e se houver a demanda; encaminhando soluções que resolvem o processo, mas não o efetivo problema; ou, ainda, adotando encaminhamentos mais geradores de demandas do que as previna, seja na esfera administrativa, seja judicial ${ }^{9}$. Nessas hipóteses, outro agente deve ser provocado para o encaminhamento da solução, o que nem sempre também significa encerrar o litígio. É o que FREITAS (2007) denomina a terceirização da solução.

Outro ponto relevante a ser consignado é que o encaminhamento da litigância intragovernamental costuma encontrar resistências porque se contempla e se teme o descuido para com a legalidade, olvidando-se de que não se trata de negociação de interesses públicos, mas a sua conciliação, a composição dos interesses públicos, mediante o cotejo e a interpretação das disposições já previstas. A inovação se circunscreve à solução encaminhada dentro de um cenário possível e previsível, que resguarda exatamente a máxima efetividade das políticas sob ameaça, dispostas que foram no arcabouço normativo.

Como acentua ÉMILIEN RUIZ em artigo Réformer l'État pour gouverner la societé, na obra organizada por LE GALÈS; VIZINAT (2014, p. 48), faz-se configurar uma nova racionalidade política, em que o Estado aprende, primeiro, a governar a si mesmo para governar os outro, reformar a administração para que esta governe a sociedade. A concepção de que a gestão está feita ou pronta é ilusória. É um processo a ser construído, aprimorado, é dinâmico, exige ser laborioso, mas as suas dificuldades também são suas prerrogativas, à medida em que há um ciclo cognitivo fundamental ao aprimoramento: aprender a fazer, realizando e observando.

A crença, segundo RUIZ $(2014)^{10}$, de que há um modelo impede explorar as possibilidades de construí-lo.

No mesmo sentido, alerta CASSIRER (1946, p. 357), que, ao explorar a face mítica do Estado, observa que temos "de aprender a obedecer às leis do mundo social antes de podermos abalançar-nos a governá-lo”.

Atos administrativos vinculados ou discricionários possuem áleas de configuração, sendo, naturalmente, mais ampla para os últimos, porém não sempre tão estreita, para os primeiros. É este um ponto relevante. Julgar o campo da legalidade muito estreito induz a uma concepção de amplitude de discricionariedade, o que não corresponde à realidade.

\footnotetext{
${ }^{9}$ Vide COSTA (2015).

${ }^{10}$ Ibid.
} 
Atentando para a afirmação de DE MASI, (2015, p. 27), de que "toda afirmação é suspeita se não for acompanhada pela devida citação das fontes", é indispensável que se esclareça não haver inovação neste comentário.

A teoria do direito administrativo nacional, ainda que na perspectiva de autores compreendidos mais tradicionais, como MEIRELLES (2016), BANDEIRA DE MELLO (2015), DI PIETRO (2016), MEDAUAR (2015), entre outros, sempre reconheceu que a legalidade está não adstrita à previsão em texto legal expresso, a desnecessidade de comando exclusivo em texto de lei ou negou a interpretação conforme a lei ou desta conforme a Constituição, hermenêutica esta consagrada também pela jurisprudência.

Da mesma forma, não há dúvidas quanto à vinculação da lei e da administração aos princípios constitucionais e a falta da lei, em sentido estrito, é suprida pela Constituição e seus fundamentos.

Em termos de configuração de litigância, há um especial fenômeno a observar na medida em que eclode um pensamento de que não há legalidade que ampare a solução do conflito e que apenas a seara discricionária encaminharia a solução, mas esta construção merece ser avaliada com reflexão, podendo gerar equívocos. Apreciando o conjunto do ordenamento jurídico, muitos encaminhamentos são viáveis mediante o processo de interpretação e adequação, antes de que se necessite ingressar no campo da discricionaridade. De outra parte, a falta de norma expressa e específica sobre determinados aspecto, exceto em exceções administrativas, como matéria financeira e, mais especificamente tributária, não exige a profusão normativa que se observa e que tende a ser uma solução imediata e aparentemente eficiente para dissipar dúvidas e questionamentos, mas que pode, ao revés, implica um fato gerador da litigância que se investiga.

A discricionariedade não é tudo que se atribui e é forçoso dizer que a cada dia mais pode se reforçar um mito, porque há uma capacidade maior de completude orgânica para a solução, no contexto valorativo expresso dos princípios constitucionais ou porque o campo da legalidade efetivamente não é estrito e comporta a construção necessária para a pacificação.

Vislumbrar de outra maneira potencializa a valorização do conflito sobre a configuração da solução. Então, prosseguindo nesta avaliação, o objetivo é demonstrar que a supremacia do conflito é preponderante sobre a possibilidade da sua solução. 
No âmbito da gestão de políticas públicas, foco deste trabalho, há possibilidade de atos administrativos vinculados ou discricionários, mas o cerne da investigação recai sobre estes, numa perspectiva de que mesmo na configuração de atos discricionários há necessidade de atendimento de parâmetros que o tornam não tão largo como em geral se denota. E mais, que a litigância intragovernamental vista na perspectiva discricionária, pode, efetivamente não se sobrepor.

Não incorrendo na ingenuidade de negar as controvérsias, o esforço intelectivo é para apontar que a visão ao avesso também pode ser uma perspectiva de valor cognitivo. Ou seja, vislumbrar que a controvérsia que fundamenta a litigância intragovernamental é realidade passível de encaminhamento é cogitar que a sua permanência apenas retarda o atendimento dos efetivos fins do Estado, consubstanciado na estrutura outorgada pela sociedade para a satisfação do bem comum.

O direito existe como parte do instrumento de materialização, tal como a seta da bússola; mas, como apenas uma parte e não o todo do instrumento, seu direcionamento depende da conformação que a este é dada. A seta aponta a posição do usuário e também a da bússola. Assim, o Estado disponibiliza o regramento social, pelo direito, e a este está submetido. Esta explicação vem delineada por KELSEN (1945, p. 169):

[...] o Estado, como ente metajurídico, como uma espécie de macrothropos onipotente, ou organismo social, pressupõe o direito e, ao mesmo tempo, sujeita-se a ele, como sujeito de direitos e deveres. É a famosa teoria dos dois rostos e da auto-obrigação do Estado, que apesar das notórias contradições que lhe são sempre imputadas defende com exemplar tenacidade contra todos os protestos.

$[\ldots]$

O Estado deve ser apresentado como uma pessoa diferente do direito para que o direito, então - esse direito produzido e a ele submetido -, possa justificar o Estado. E o direito só pode justificar o Estado se for contraposto como ordem essencialmente diferente do Estado, cuja natureza original, o poder, é por ele pressuposto como ordenamento correto e justo. 
O conteúdo do direito depende de como a sociedade se organiza e, assim, viabiliza a existência do Estado. Ao afirmar o direito na perspectiva do positivismo (jurídico) KELSEN (1945, p. 85) expressa que o "objetivo da Teoria Pura do Direito é livrar, desligar totalmente o conceito de norma jurídica do conceito de norma moral da qual se origina, e assegurar a legalidade do direito também perante a lei moral.”. Porque o conteúdo do que é valorado juridicamente está além do dizer dessa ciência. É apenas sobre o valor atribuído a um conteúdo que se instrumentaliza o aporte jurídico.

A esta expressão, há de se adicionar a lição de O’DONNELL (2011, p. 112/113), para quem o Estado não se afasta da observância e da implementação do direito que estabelece, mas atenta para o que deve estar nesse conteúdo:

[...] não existe algo como um estado neutro, orientado de maneira puramente técnica. Os estados condensam, processam e geram relações de poder que existem tanto na sociedade (a doméstica e a transnacionalizada) quanto em suas instituições. [...] proponho um novo direito, um direito que, segundo meus conhecimentos, não foi ainda reconhecido pela teoria política ou legal. Nós, como cidadãos e/ou membros da nação/povo, temos um direito público e irrenunciável ao estado, mas não a qualquer estado; temos direito a um estado que, obtendo notas razoavelmente satisfatórias em suas quatro dimensões ${ }^{11}$, converta-se em um coconstrutor e promotor de versões razoáveis de bem comum, assim como dos vários aspectos da

\footnotetext{
${ }^{11}$ Há uma nota de rodapé em O'Donnell (2001, p. 93) de fundamental importância conceitual, especialmente ao se considerar que esta pesquisa se insere numa avaliação multidisciplinar:

"Lutei contra a confusão terminológica provocada pelos vários significados de nação, povo e cidadania, todos termos discutíveis e com um forte caráter político e ideológico. No esforço para atenuar os problemas expositivos resultantes, utilizo a tosca expressão 'nação/povo/cidadania' nas frases em que o referente pode não ser totalmente claro, para indicar que estou falando sobre todos estes termos juntos; também em outros contextos onde me refiro aos três em conjunto, utilizo as palavras mais genéricas 'país' ou 'população'. Por outro lado, quando utilizo o termo 'nação' refiro-me a esta como na definição acima e, por conseguinte, também ao primeiro significado de 'povo'. Finalmente, 'sociedade' é um conceito sociológico que, embora possa se referir ao mesmo universo empírico que os primeiros termos (se é aplicado à população vinculada a um estado determinado) é mais neutro politicamente e oferece uma perspectiva analítica diferente; este será o termo predominante quando discuto a dimensão legal do estado."
} 
cidadania resultante da democracia. Este tipo de estado é âncora e promotor da cidadania. É o único lugar institucional em que os direitos podem ser inscritos (em seu sistema legal) e implementados (por burocracias relevantes). Os direitos não existem no ar ou apenas em discursos; existem, poder ser exigidos, e não podem ser facilmente revertidos, quando se convertem em parte efetiva e amplamente reconhecida da legalidade do estado, e quando suas burocracias orientam seu desempenho apoiando sua existência.

Ainda sob os auspícios de O’DONNELL (2011, p. 134) convém advertir que não se pode confundir o fim do Estado com as finalidades dos que ocupam o governo, no preenchimento enquanto poder político:

Em geral, os chefes oscilam entre seu interesse em ter poder total sobre seus subordinados e seu interesse em motivá-los adequadamente e [...] criar normas com controles sobre seu desempenho.

[...] (sobre as burocracias estatais). Seu crescimento em quase todos os países suscitou um tema imprevisto pelos primeiros teóricos do estado de direito e da democracia, e atualmente ignorado por vários dos teóricos contemporâneos. Refiro-me às inumeráveis regras que têm a forma e muitas das consequências da lei, emitidas pelas burocracias estatais. Este direito administrativo sanciona, define e às vezes dificulta direitos e obrigações. Isto significa que muitas burocracias estatais se transformaram na verdade em colegisladoras com o parlamento, assim como com o poder judiciário. Embora se suponha que as regras e decisões das primeiras encontram-se sujeitas em última instância a controles judiciais/constitucionais, existe evidência de que a efetivação desses controles por parte dos cidadãos(dãs) é muitas vezes difícil e cara. Este problema normalmente se agrava pela atração da burocracia pelo secreto e por projetar relações autoritárias interna e externamente.

No caso dos países da América Latina, a fragilidade do estado é expressa em uma frenética quase-legislação expedida por burocracias diversas e, às vezes, em conflito. Isto, somado as tendências autoritárias alimentadas pela grande distância social que separa essas burocracias dos marginalizados e 
excluídos, dá forma a uma das faces do estado - certamente muito desagradável.

Ainda assim, independentemente das diferenças entre os países, a colegislação e a coadjudicação burocrática são aspectos importantes da vida social e política; parece claro que isso está diretamente relacionado com a efetividade e extensão dos direitos de cidadania e, em consequência, com a qualidade da democracia. Mas as teorias da democracia que se concentram exclusivamente no regime, precisamente porque em virtude desse foco ignoram o estado, passam ao largo desta questão.

A compreensão do Estado forte, ou não, depende da apreensão dessa força manifesta na atuação necessária à satisfação do bem-estar, mas a sua ausência é percebida na falta da prestação das políticas públicas que perscrutam o ávido contexto social. Para determinados contextos, a abstenção do Estado gera a liberdade de agir e auto-tutela, demando que se configura no sentido inverso, para que possa haver a liberdade, como pontuou DAHL (1985, p. 22), referindo a preocupação de TOCQUEVILLE ${ }^{12}$ (1988, p. 38) com o equilíbrio entre a democracia e a liberdade.

Concebendo que o mister estatal viabiliza a prestação social inclusive na forma democracia delegativa e que há um escalonamento hierárquico para a observância desse dever O’DONNELL (2011, p. 134) especifica como se operacionaliza a estrutura executiva para a efetivação do bem-estar social:

A decisão tomada por determinado indivíduo só é imputada como ato estatal porque certas regras definem que tal ato realizado por tal indivíduo, tendo cumprido certos requisitos prescritos legalmente, qualifica-se como uma decisão 'oficial' (i.e. estatal). Como disse Hosle (2004, p. 498):

"O estado existe como estrutura social e legal apenas na medida em que certas pessoas realizam certos atos - embora elas realizem estes atos com a consciência de que estão contribuindo para uma ordem que, de acordo

12 "Instruir a democracia, reanimar, se possível, suas crenças, ordenar seus movimentos, substituir pouco a pouco sua inexperiência pela ciência dos assuntos públicos, e seus instintos cegos por seus verdadeiros; adaptar seu governo aos tempos e aos lugares; modificá-la segundo as circunstâncias e os homens: tais são os primeiros deveres que se impõem, em nossos dias, a quem dirige a sociedade.” (p. 38). 
com seu significado último, vai além de sua própria existência e está legalmente estruturada. As pessoas jurídicas não podem ser concebidas como ficções ou como entidades realmente existentes independentes dos seres humanos que a sustentam - são esquemas de imputação e, como tais, por um lado, e por outro fazem com que seja possível avaliar de maneira precisa seu comportamento. $\mathrm{O}$ fato de o estado ter certos direitos significa que certas pessoas têm direitos equivalente, não com o pessoas privadas mas sim como pessoas que exercem certo cargo."

O "esquema e imputação" é a cadeia de autorizações outorgadas legalmente que criam a unidade real, embora subjacente e pouco visível, do estado. A dimensão jurídico/legal do estado lhe outorga suas unidades, é o fio que une as partes. Por outro lado, contra interpretações excessivamente legalistas, esta dimensão não é todo o estado; é a parte que coloca diante de nós indivíduos que têm a vantagem de ter certa categoria de suas atividades definida legalmente como parte e emanação da autoridade do estado dando origem a seus respectivos poderes.

$[\ldots]$

Além disso, devemos observar que esta cascata de autorizações é uma característica única do estado moderno: é a manifestação de sua dimensão legal e a consequência das diversas expropriações que [...] foram parte do surgimento do mesmo.

O que promove a quebra no encadeamento natural que deveria ter a satisfação dos interesses públicos pela implementação das políticas públicas, veículo com que o Estado emprega seu mister de promoção do bem-estar social? O que tem condão de interromper este fluxo?

A litigância demanda tempo, orçamento, desgasta as relações gera impactos econômicos, prejudica a sociedade. Empiricamente é de se afirmar com segurança que o custo da solução resguarda a vantajosidade para a administração. Remover o obstáculo é o requisito para a gestão, mas este trabalho exige, ao mesmo tempo, o aproveitamento da divergência para a construção.

Não obstante, a agenda pública esteja condicionada à inexistência da controvérsia geradora da litigância intragovernamental e esta se configura mediante o estabelecimento de 
situações de competência positiva ou negativa vale dizer, pela identificação de que o problema compete ou não ao órgão ou entidade encaminhar; pela sobreposição geográfica de políticas públicas; pela tomada de decisão que extrapola os limites dos interesses exclusivos do órgão ou entidade prolator, passando a atingir o patrimônio, o interesse ou a competência de outro órgão ou entidade públicos, diante da forma de interpretação normativa incompatível.

As situações narradas são entraves à agenda pública e impactam de maneira desfavorável na concepção da burocracia estatal. Paralelamente a esta realidade, na concepção de WEBER (2015, p. 18-19), apresentada na introdução de uma coletânea de artigos seus, na obra "Escritos Políticos":

[...] "há uma estreita afinidade entre a democracia moderna e a burocracia", uma vez que as "demandas por ações tipicamente geradas em Estados democráticos poder ser apenas atendidas por uma administração burocrática em larga escala".

Como discorrido anteriormente, a estrutura do Estado, impactada pela litigância, sofre empecilho ao alcance de sua(s) finalidade(s). O impacto é ainda mais relevante quando se contempla que a satisfação do bem-estar social deve ser dimensionado na perspectiva teleológica de promover a dignidade da pessoa humana, expressão cunhada e justificada por SARLET (2015, p. 89-90) para explicar que o Estado deve ter a capacidade de proteger e dar meios de vida digna entre os seres e para cada ser:

Nesse contexto, não restam dúvidas de que todos os órgãos, funções e atividades estatais encontram-se vinculados ao princípio da dignidade da pessoa humana, impondo-se-lhes um dever de respeito e proteção, que se exprime tanto na obrigação por parte do Estado de abster-se de ingerências na esfera individual que sejam contrárias à dignidade pessoal, quanto no dever de protegê-la (a dignidade pessoal de todos os indivíduos) contra agressões oriundas de terceiros, seja qual for a procedência, vale dizer, inclusive contra agressões oriundas de outros particulares, especialmente mas não exclusivamente - dos assim denominados poderes sociais (ou 
poderes privados). Assim, percebe-se, desde logo, que o princípio da dignidade da pessoa humana não apenas impõe um dever de abstenção (respeito), mas também condutas positivas tendentes a efetivar e proteger a dignidade dos indivíduos, Por outro lado, ainda nessa linha de raciocínio, sustenta-se, com razão, que a concretização do programa normativo do princípio da dignidade da pessoa humana incumbe aos órgãos estatais, especialmente, contudo, aos legislador, encarregado de edificar uma ordem jurídica que atenda às exigências do princípio. Em outras palavras - aqui considerando a dignidade como tarefa -, o princípio da dignidade da pessoa humana impõe ao Estado, além do dever de respeito e proteção, a obrigação de promover as condições que viabilizem e removam toda sorte de obstáculos que estejam a impedir as pessoas de viverem com dignidade. Da dupla função de proteção e defesa segue também o dever de promover medidas de precaução procedimentais e organizacionais no sentido de evitar uma lesão da dignidade e dos direitos fundamentais ou, quando isto não ocorrer, com o intuito de reconhecer a fazer cessar (ainda que para efeitos simbólicos), ou, de acordo com as circunstâncias, minimizar os efeitos das violações, inclusive assegurando a reparação do dano.

A citação é extensa, mas o empenho em transcrevê-la compensa a possibilidade de demonstrar que a litigância retarda uma discussão de maior relevo e intensidade, que a lição abordada acima está postergada, desde 1988, data da Carta Política.

WEBER (2015, p. 136) ponderava, no artigo "Sufrágio e Democracia na Alemanha", que não existe espaço vazio de interesses, de maneira que a análise a ser produzida sobre a perpetuidade de entraves burocráticos deve contemplar que a falta de solução do conflito pode vir a ser uma forma de atender a interesses alheios à finalidade estatal. $\mathrm{O}$ espaço que se rende à litigância é campo que se nega à implementação das políticas públicas, que induzem à satisfação da efetiva finalidade do Estado. A qual interesse serve este fenômeno? No contexto de não acatamento do Estado aos seus efetivos fins, por certo, há resultados que não são os previstos seja na Constituição, seja na forma de prover os cargos eletivos na administração, seja na contemplação que tal Carta elencou com direitos e garantias.

Ainda citando WEBER (2015, p. 130, grifo do autor), vale a pena observar o que discorre sobre a força da manifestação eleitoral do cidadão em face da burocracia: 
Diante do domínio nivelador e inescapável da burocracia, que foi o primeiro a fazer surgir o conceito moderno de "cidadão do Estado", a cédula eleitoral é o único instrumento de poder capaz de proporcionar às pessoas subordinadas à burocracia um direito mínimo de participar das decisões relativas aos assuntos da comunidade em prol da qual são obrigadas a entregar a sua vida.

Releva aqui trazer a amplitude da proteção necessária, em cotejo com universo da litigância intragovernamental, em que se envereda mais uma vez aos auspícios de SARLET (2015, p. 92-93, grifo do autor):

A própria eficácia dos direitos fundamentais nas relações entre os particulares - ainda que em condição de tendencial igualdade (e, portanto, de igual liberdade) - tem encontrado importante fundamento no princípio de dignidade da pessoa humana, sustentando-se, nesse contexto, que - pelo menos no que diz com seu conteúdo em dignidade - os direitos fundamentais vinculam também diretamente os particulares nas relações entre si, sendo - na esfera deste conteúdo - irrenunciávies, já que, à evidência, e, como bem lembra Jörg Neuner, em termos de uma eficácia vinculante da dignidade, "não importa de quem é a bota que desferiu o chute no rosto do ofendido". Assim, percebe-se, na esteira do que já foi anunciado alhures, que o dever de proteção imposto - e aqui estamos a nos referir especialmente ao poder público - inclui até mesmo a proteção da pessoa entra si mesma, de tal sorte que o Estado se encontra autorizado e obrigado a intervir em face de atos de pessoas que, mesmo voluntariamente, atentem contra sua própria dignidade, o que decorre justamente do já referido cunho irrenunciável da dignidade pessoal. Vale frisar, ainda, que se dá dignidade - na condição de princípio fundamental - decorrem direitos subjetivos à sua proteção, respeito e promoção, seja pelo reconhecimento de direitos fundamentais específicos, seja de modo autônomo, igualmente haverá de se ter presente a circunstância de que a dignidade implica também, já por força de sua dimensão intersubjetiva, a existência de um dever geral de respeito, mas 
também (e de certa forma) até mesmo um dever das pessoas para consigo mesmas.

O que importa ter presente, a esta altura, é que a função da dignidade de como limite e tarefa guarda sintonia tanto com a dimensão objetiva do princípio da dignidade da pessoa humana, implicando um feixe de deveres de proteção estatais, abarcando medidas de natureza organizacional e procedimental, quanto, na dimensão subjetiva, o reconhecimento e garantia de um conjunto de direitos fundamentais de caráter defensivo (negativo) e prestacional (positivo). Mas, por maior que seja a conexão desse ponto com a problemática aqui abordada (dignidade como limite e tarefa) aqui já nos encontramos no domínio da relação da dignidade da pessoa humana com os direitos fundamentais [...].

A pendência da prestação estatal deixa violar a expectativa da agência frente ao Estado investido do poder democrático, segundo o entendimento também abordado por FERRAJOLI (2012, p. 23, grifo do autor), quando, ao destacar o constitucionalismo garantista, ressalta a relação entre democracia e positivismo jurídico:

Sob este aspecto, podemos falar de um nexo entre democracia e positivismo jurídico que se completa com a democracia constitucional. Este nexo entre democracia e positivismo geralmente é ignorado. Entretanto, devemos reconhecer que somente a rígida disciplina positiva da produção jurídica está em grau de democratizar tanto a sua forma quanto os seus conteúdos. O primeiro juspositivismo, aquele do Estado Legislativo de Direito, equivale à positivação do "ser" legal do direito, que permite a democratização das suas formas de produção, condicionando-lhe a validade formal ao seu caráter representativo, sobre o qual se funda a dimensão formal da democracia política. O segundo juspositivismo, aquele do Estado Constitucional de Direito, equivale à positivação do "dever ser" constitucional do próprio direito, que permite a democratização dos seus conteúdos, condicionando-lhe a validade substancial à sua coerência com aqueles direitos de todos, que são os direitos fundamentais, e sobre os quais se funda a dimensão substancial da democracia constitucional. Graças ao primeiro positivismo jurídico, foi confiado o "quem" e o "como" da 
produção normativa a sujeitos politicamente representativos dos governos. Graças ao segundo, foi vinculado o "quê" das normas produzidas à garantia dos seus interesses e necessidades vitais. O clássico e recorrente contraste entre razão e vontade, entre lei da razão e lei da vontade, entre direito natural e direito positivo, entre Antígona e Creonte, que atravessa toda a filosofia jurídica e política, da Antiguidade ao século XX, e entre governo das leis e o governo dos homens, foi assim resolvido pela atuais Constituições rígidas através da positivação da lei da razão, mesmo que historicamente determinada e contingente, na forma dos princípios e dos direitos fundamentais neles estipulados como limites e vínculos, à lei da vontade, que, na democracia, é a lei regido pelo princípio da maioria.

O anunciado acima não apregoa a carência de normas para efetivar os direitos fundamentais, antes descritos na transcrição de SARLET (2015), pois a pretensão com a recente referência é justamente anunciar que há texto constitucional a ser referendado pela prática estatal, não está por realizar, a legislação da razão que guarda a proporção hierárquica com o texto constitucional já existe, as normas pendem da sua efetivação.

De outra parte, a inércia em colmatar as falhas em curso nega o papel definido ao Estado, posterga o exercício dos direitos fundamentais e neste campo há que se acomodar, tanto a dimensão cidadã de quem voluntariamente dispensa determinadas iniciativas (políticas públicas) estatais, preferindo o exercício de sua liberdade de iniciativa, quanto os que verdadeiramente dependem de diversas ações do Estado inclusive para sobrevivência.

Não se concebe neste trilhar a existência dos comandos (FERRAJOLI (2012) para a administração (KELSEN (1934) e não se nega a necessidade da acepção burocrática (WEBER (2015), mas se instiga a efetivação dos programas e das políticas públicas (SARLET (2015), obstadas de forma claudicante pelo emaranhado formal em que o Estado (O’DONNELL (2011)) não aprendeu a se gerir (RUIZ (2014)) $)^{13}$ para administrar a sociedade.

13 Ibid. 
4. Cotejo da Litigância Intragovernamental, em Face dos Conceitos de Democracia, Agência, Estado, República, Discricionariedade e Gestão de Políticas Públicas

O sentido que se tem procurado atribuir à presente investigação é questionar o quanto do esforço do Estado é empregado para atingir esta condição, vislumbrada como decorrente do interesse e da vontade coletiva. Integra este empenho a observação sobre em que medida o Estado encara o atendimento de seus destinatários ou volta apenas a si mesmo, remunerando uma estrutura para prosseguir o que é.

Os conceitos constantes do tópico já foram enfrentados neste trabalho, com a contextualização dos autores que os investigam. Permanece, entretanto, a indagação: como se configuram tais elementos (do Estado) diante de uma realidade em que o cidadão precisa se comunicar com a administração que não se articula?

O tralhoto é um peixe de água doce conhecido como "quatro olhos". Seu nome científico é Anableps anableps e sua característica mais marcante é que seus olhos têm uma divisão em duas partes, uma aérea e outra aquática e, desta forma, pode nadar na superfície da água, enxergando acima e abaixo dela, porque sua conformação de íris propicia esta façanha. Falta esta habilidade, que ainda pode ser desenvolvida, aos estadistas.

A conformação do Estado não lhe possibilita apenas o olhar interno, mas a concomitância contínua, porque a delegação recebida para administrar pode ser aprimorada, como inspira BAUMAN (1999, p. 158-159, grifo do autor), ao demonstrar que, ao não desenvolver o seu mister o Estado chega a renunciar a si mesmo, deixando que atuem padrões que o negam e solapam:

[...] a sociedade civil torna segura a liberdade individual - na verdade, segura ao ponto de na vida cotidiana achar-se que está garantida e não ser mais notada, quanto mais colocada como uma questão. É provável que o Estado respeite essa liberdade e se abstenha de interferir nas opções dos súditos, quer esses súditos fiscalizem o risco de tal interferência ou dêem as costas ao problema. Isso é ótimo; menos atraentes, no entanto, são os dois extremos que esse esplêndido isolamento mútuo da política e da vida cotidiana promovido pela sociedade civil pode estimular e propiciar. Um produto mal acolhido da separação são os súditos não mais estimulados 
pela situação política ou pela política de Estado, que não esperam nem condenação nem redenção para descer do topo - e assim como não pensam nos dentes depois que passa a dor de dentes, não vêem razão para questionar o significado de bem comum, quanto mais discuti-lo, contestálo ou ativamente buscá-lo. Outro é que o Estado é encorajado assim a supor que, como não há interferências contra a liberdade, o conteúdo do bem comum foi exaurido e o Estado anda mais deve a seus súditos - nem tem responsabilidade pelos danos causados a todos os súditos pelo egoísmo, inépcia ou estreiteza com que alguns exercem sua liberdade. A sociedade civil, em outras palavras, tem seus esplendores e suas inclinações menos cativantes. Uns e outras são muito mais difíceis de separar do que o Estado e a sociedade se revelaram até aqui. A indiferença e apatia políticas dos cidadãos e a renúncia do Estado a sua obrigação de promover o bem comum são filhos desagradáveis mas legítimos da sociedade civil.

Para exemplificar a gravidade de sua assertiva, BAUMAN (1999, 158-159) transcreveu declaração conjunta consignada por sete intelectuais franceses no jornal Le Monde, no mesmo ano na edição original de sua obra - 1998:

Sete intelectuais franceses, dentre os quais Régis Debray, Max Gallo e Mona Ozouf, observaram recentemente (ver sua declaração conjunta com o comovente título "Republicanos, rejeitemos a nação de dois andares!", publicado no Le Monde de 20 de outubro de 1998), alguns perigosos indícios de uma progressiva deformação da democracia liberal "realmente existente", resultantes da crescente insegurança de uma ampla parcela da população, uma parcela cada vez maior.

Se a República, que outrora fez um pacto de paz e segurança com suas classes populares, mostra-se incapaz de garantir ambas as coisas e, pior ainda, dá a impressão de que toda atenção por alguma ordem pública é por sua própria natureza reacionária, então há uma grande tentação de apelarmos para a autodefesa. 
BAUMAN (2014) reforça o convite à participação da sociedade, que se manifesta numa democracia, através de expressão da vontade em processo eleitoral, mas que não acompanha o desempenho do então previsto. Para além da composição legislativa que descreve KELSEN (1934, p. 110) a seguir, apartando duas formas de participação popular, uma direta (eleição) e outra indireta (legislação), na composição do direito, a administração é investida no processo direto para a execução no mandamento legal:

Pensa-se, entretanto - quando, quase sempre, se trata do ordenamento jurídico personificado como 'vontade estatal'- apenas na manifestação geral das normas jurídicas que constituem esse ordenamento nas leis. A participação dos submetidos às normas na legislação é a marca da forma de Estado democrática, diversa da autocracia, que exclui todos os súditos de toda participação na formação da vontade estatal.

A legislação democrática pode-se desenvolver ou de modo imediato, através do 'povo', ou seja, pelos submetidos às normas, à qual corresponde - na denominada democracia direta - o direito subjetivo do indivíduo de participar na assembleia popular legislativa, com voz ativa e voto. Ou a legislação coloca o povo diante da imediatidade, o que significa que é ditada por um parlamento eleito pelo povo. Neste caso, o processo de formação da vontade estatal - ou seja, a criação geral do direito - é classificado em dois estágios: a eleição do parlamento e a votação das leis pelos parlamentares eleitos.

Em seguida, KELSEN (1934, p. 111) menciona a investidura judicial, associada à legislativa, na composição do arcabouço normativo pela qual se rege o Estado, mas que não é fim em si mesmo:

[...] um direito subjetivo dos eleitores - que formam um círculo maior ou menor: o denominado direito de voto; e um direito subjetivo dos relativamente poucos - eleitos: o direito a ser membro do parlamento, o direito de votar e ser votado. Esses são os direitos políticos, caracterizados por facultarem uma participação na formação da vontade estatal, o que torna também o direito subjetivo privado um direito político; isso também 
permite aos autorizados que participem na formação da vontade estatal. Esta se expressa na norma individual da sentença judicial não menos que na norma geral da lei. E quando o direito privado subjetivo pode ser unido ao direito político, sob o mesmo conceito de autorização, isso só acontece no caso de ambos terem função jurídica idêntica: a participação dos submetidos às normas na criação do direito, portanto a expressão da função de produção jurídica.

A denominada autorização 'política', no sentido mais restrito da palavra, permite a participação na produção da norma geral, e a autorização de direito privado permite a participação na produção da norma individual.

Advertindo sobre a missão, mas também sobre a possibilidade da negativa desta, O'DONNELL (2011, p. 68) repercute que:

[...] estado processa e condensa poderes que emergem da sociedade (em nível local, internacional e transnacional), e também gera seus próprios poderes. Como resultado o estado devolve à sociedade vários tipos de políticas públicas e, às vezes, também importantes omissões.

Rememora O'DONNELL (2011, p. 73) que democracia contém o vislumbre de bemestar, embora reconheça o escasso poder que na América Latina tem os governos eleitos democraticamente e, em geral, os Estados que contêm um regime democrático, para governar efetivamente sobre questões importantes e, mais, para avançar na democratização e no bem-estar de seus respectivos países.

Mediante uma visão geral de que a investidura no poder é vinculada a uma previsão de governo, a discricionariedade não é tão ampla como aparenta porque existe um iter de construção da estrutura de ação estatal na configuração democrática que limita ou previne que a discricionariedade se afaste de uma construção com nexo de causalidade ou que desborde ao arbítrio.

É de se questionar em que medida e a que interesses se vincula a ampliação de perspectivas para a discricionariedade. 
Mesmo a democracia, como conceito globalmente aceito como sendo o melhor regime dentre outros ${ }^{14}$, não é tão hegemônica em termos de vontade de todos, mas é o freio necessário, na ausência de outros. O preenchimento democrático do poder político deixa de ser vazio à medida em que o Estado assume as suas dimensões nessa expectativa de ser jurídica e politicamente investido. Afinam-se nesta avaliação os ensinamentos de KELSEN (1934, p. 187), e O'DONNELL (2011, p. 68-69, grifo do autor), este com as cinco dimensões do Estado, que assim descreve:

[...] o estado pode ser convenientemente diferenciado em pelos menos quatro dimensões. Uma, a mais óbvia, é o estado como conjunto de burocracias. Estas burocracias, geralmente organizações complexas, têm responsabilidades atribuídas legalmente para a proteção ou obtenção de algum aspecto do bem comum. Irei me referir a esta dimensão e ao grau em que se cumprem essas responsabilidades como a de eficácia do estado. O estado é também um sistema legal, uma trama de regras que permeiam e codeterminam inúmeras relações sociais, tanto na sociedade quanto dentro das burocracias estatais. Atualmente, especialmente nas democracias e como consequência dos processos que examinamos no capítulo anterior, existe uma forte conexão entre as burocracias do estado e o sistema legal: supõe-se que estas burocracias atuem de acordo com faculdades e responsabilidades que lhes são legalmente atribuídas pelas autoridades pertinentes - o estado contemporâneo se expressa normalmente na linguagem da lei. Irei me referir a este aspecto como o grau de efetividade do sistema legal do estado.

Juntos, presume-se que as burocracias e o sistema legal do estado geram, para os habitantes de seu território, o grande bem público da ordem geral e da previsibilidade das relações sociais. Ao fazê-lo o estado (mais precisamente os funcionários autorizados a decidir e atuar em seu nome) afirma privilegiar o bem comum e garantir a continuidade histórica da população do respectivo território. Esta proclamada contribuição nos leva

\footnotetext{
${ }^{14}$ Atribuir-se-ia a Churchill a afirmação de que a democracia é a pior forma de governo, exceto todas as outras ("Democracy is the worst form of government, except for all the others."), mas há controvérsias quanto a esta afirmação autoral, nada obstante o aforisma enseje interessante questionamento.
} 
a uma terceira dimensão do estado: a de ser, ou tentar ser, um foco de identidade coletiva. Tipicamente os funcionários do estado, especialmente os que ocupam posições em sua cúpula institucional, afirmam que seu estado é um estado-para-a-nação ou [...] um estado-para-o-povo, ou paraa-cidadania. Com estas afirmações, repetidas de inúmeras maneiras, a cúpula de estado (e os governos) convida ao reconhecimento generalizado de um nós que expressa uma identidade coletiva distintiva que, de acordo com o que se postula com frequência, deveria prevalecer sobre os interesses que emergem de várias clivagens sociais. Irei me referir a esta dimensão com grau de credibilidade do estado.

Ainda nos resta uma quarta dimensão. O estado é um filtro que tenta regular o grau de abertura e fechamento dos diversos espaços e fronteiras que mediam o interior e o exterior de seu território, seu mercado e sua população. Algumas destas fronteiras demarcam essa população e, sob um regime democrático, seu eleitorado. Outras são espaços delimitados de forma menos marcante; alguns deles são cuidadosamente protegidos, outros estão controlados com maior ou menor efetividade por vários tipos de políticas, outros ainda nunca tiveram barreiras e alguns as perderam, carcomidas pelos ventos da globalização. No entanto, todos os estados tentam, ou afirmam que tentam estabelecer vários filtros para o bem-estar de sua população e dos atores econômicos situados em seu território. Essa é a dimensão de filtragem do estado.

Existe ainda outro aspecto do estado que em seu significado não é, como nos casos anteriores, uma dimensão historicamente contingente e sim uma característica atribuída institucionalmente. Refiro-me ao fato de o estado se constituir como tal quando outros estados no sistema internacional, assim como, em épocas mais recentes, as Nações Unidas e outras organizações públicas internacionais o reconhecem, independentemente da valência tenha adquirido nas dimensões previamente mencionadas.

A dimensão do Estado aqui tão explorada tem como objetivo apontar para o papel que urge ser incorporado e é exatamente a falta desta vivência política que faz grassar a litigância intragovernamental, o óbice aos primados da boa administração. 
Até o quinto elemento de configuração do Estado, trazido acima por O’DONNELL (2011) e igualmente enaltecido por KELSEN (1934), implica especial interesse para esta avaliação, à proporção em que o reconhecimento internacional do Estado, por se constituir ordenamento jurídico estatal singular, é um ponto importante porque no caso em estudo neste trabalho, a consulta às comunidades quilombolas decorreu de atendimento de uma convenção internacional, homologada em território nacional e sobre esta o País chegou a ser questionado posteriormente.

Ainda se identifica uma conexão com KELSEN (1934) quando O'DONNELL (2011, p. 116) este destaca que a lei é "uma dimensão fundamental do Estado, proporciona a estrutura subjacente que sustenta as relações sociais de uma sociedade". Esta afirmação empodera não apenas para o exercício consagrado da coerção, mas para a concretude do desiderato do bem-estar, razão de ser do regramento legal.

A indisponibilidade dos elementos do Estado indica que o contexto legal é o instrumento para a gestão, de maneira que não é a sobreposição da vontade do homem, mas do arcabouço que deve servir de suporte à democracia, o que O'DONNELL (2011, p. 123124) assim prestigia:

Como disse Holmes (1995, p. 6), ‘As constituições não apenas limitam o poder e previnem a tirania, também constroem poder, orientam-no para fins socialmente desejáveis, evitam o caos social e a opressão privada ... uma constituição é um instrumento do governo. Estabelece regras que sustentam a democracia'.

$[\ldots]$

As preferências diferem com frequência, e às vezes ingressam na política como questões que, de alguma forma, têm de ser decididas. São o que Waldron denomina "as circunstâncias da política". "A existência (inevitável) da discordância e da necessidade, apesar da discordância, de criar um quadro comum que (se aplique) tanto a temas de direitos quanto a o que é normalmente considerada uma modesta agenda de política legislativa." Para esta necessidade social básica, a democracia proporciona dois ingredientes essenciais: um, eleições honestas que provêm uma maneira pacífica de decidir quem ocupará as posições autorizadas; e dois, políticas públicas baseadas em regras legais adequadamente sancionadas e 
na indisponibilidade dessas regras para os governantes. [...] Isto significa que a democracia fornece mecanismos para a tomada de decisões e (pelo menos em princípio) garantias de que preferências e interesses importantes de seus membros sejam considerados. Isto é conseqüência de uma característica única da democracia [...]: sua atribuição universalista e com amparo legal de agência a todos os cidadãos(dãs).

A teoria de O’DONNELL (2011) não dá azo à falta de resolutividade, ao indicá-la como imanente ao regime democrático. Antes havia apontado para a conformação da burocracia para o atendimento dos fins do Estado. Acima, indicou a potencialidade de amparo geral, do que não se pode furtar o ocupante do cargo público, ao se compreender que esta é a sua missão precípua.

A consideração de que o Estado não é um fim em si mesmo, mas que sua existência está fundada no implemento de determinadas condições e para um fim coletivo tem um registro final em O’DONNELL (2011, p. 126):

Há ainda outro aspecto que quero mencionar. O entrelaçamento do estado e da sociedade por meio da dimensão legal de um estado que abriga um regime democrático, é o fundamento da distinção entre a esfera pública e a privada. A distinção entre a esfera pública e privada foi criticada com base na evidência de que existem áreas cinzentas de interpenetração entre o estado e a sociedade. Isto é correto, mas nesses argumentos normalmente considera-se o "estado" como formado apenas por suas burocracias, esquecendo sua dimensão legal. [...] a esfera pública é formalmente ocupada por funcionários do estado, eleitos ou não, e diversamente povoada por atores e discursos que articulam questões de interesse geral. Como mencionei, esses funcionários têm direitos específicos, mas estes são legítimos só por serem necessários ao cumprimento das obrigações atribuídas a seus respectivos cargos. Aqui a lei imprime outra dimensão moral, além daquela da concepção do cidadão como agente. Esta segunda dimensão foi enfatizada pela tradição republicana, em sua exigência por devoção desinteressada dos governantes ao bem comum.

$[\ldots]$ 
$\mathrm{Na}$ democracia, a convicção que a origem e justificação da autoridade desses funcionários provêm da cidadania leva, com força especial, a expectativa de que essa autoridade deve ser utilizada exclusivamente para o bem desta (por mais que cada decisão de política pública envolva questões específicas e problemáticas). É claro, essa mesma convicção serve de base para as várias sanções legais que - supõe-se - acompanham as violações dessas obrigações por parte dos funcionários estatais.

Aproximando a doutrina de O’DONNELL (1988 e 2011), sob outro viés, com BAUMAN (1999, p. 162) e LATOUR (2012, p. 89), está a possibilidade de acompanhamento de tudo por todos, na forma que se lhes importa compor, ad hoc ou de forma permanente, mediante coletivos aleatoriamente compostos, mas para que a existência do coletivo estatal leve a um fim efetivo e interfira para o desenvolvimento humano, com a solução da litigância intragovernamental:

$\mathrm{Na}$ democracia, as discrepâncias percebidas possibilitam ações individuais e/ou coletivas de voz e de accountability horizontal, bem como “accountability social” por vários meios, que incluem meios legais, ONGs, movimentos sociais e diversas associações que trazem à luz pública essas discrepâncias. Este é um indício significativo da importância moral dos valores republicanos expressos nas regras legais as quais, com a exceção ocasional de governantes particularmente desonestos, eles e outros habitantes da esfera pública obstinadamente declaram sua adesão.

Estes aspectos estão na análise de um contexto administrativo em que se configurou litigância intragovernamental decorrentes da execução de políticas públicas 


\section{A CONFIGURAÇÃO DA LITIGÂNCIA INTRAGOVERNAMENTAL E O TRATAMENTO DISPENSADO: A POLÍTICA DE TITULAÇÃO DE COMUNIDADES QUILOMBOLAS E AS POLÍTICAS DE CUNHO AMBIENTAL, DE SEGURANÇA NACIONAL E DE NATUREZA AGRÁRIA. APLICABILIDADE DO DECRETO N 4.887, DE 20 DE NOVEMBRO DE 2003.}

\section{Relato do Caso}

O caso a ser estudado neste trabalho diz respeito a um procedimento em mediação em tese, desenvolvido no âmbito da Advocacia-Geral da União (AGU), com a participação da autora, na condição de advogada da União e secretariando as atividades efetivamente desenvolvidas pelo Consultor-Geral da União, assunto documentado no processo administrativo $\mathrm{n}^{\circ}$ 00400.004590/2007-11, atualmente guarnecido em arquivo intermediário, mas integralmente reproduzido em mídia para ser encartado como anexo a dissertação.

De acordo com CZARNIAWSKA-JOERGES (1997, p. 64) um estudo de caso é uma investigação empírica que: examina um fenômeno atual com seu contexto real; quando os limites entre o evento e o contexto não claramente evidenciados; e no qual múltiplas fontes de evidências são utilizadas. ${ }^{15}$

O registro sobre o procedimento a seguir tem como base o relatório final dos trabalhos desenvolvidos pelo grupo de trabalho então formado, fazendo-se questão de consignar os pormenores da vivência administrativa, a fim de que, como se observará adiante, tal proceder possa ser cotejado com os comentários consignados pelas entrevistas, que avaliam especialmente aspectos favoráveis e desfavoráveis para a ótica deste trabalho, que cogita a avaliação sobre o implemento de políticas públicas na confluência de conflito administrativos, incorporados nesta via de pesquisa sob a perspectiva conceitual de litigância intragovernamental.

A narrativa teve corpo em meados do ano de 2007, havendo as atividades do grupo tomado agenda da Consultoria-Geral da União por um ano e dois meses.

\footnotetext{
${ }^{15}$ No original: A case study is an empirical inquity that: investigates a contemporary phenomenon within its real-life context; when the boundaries between phenomenon and context are not clerarly evident; and in which multiple sources of evidence are used (YIN, 1984, p. 23).
} 
As políticas públicas referentes ao reconhecimento e à titulação de comunidades quilombolas e de comunidades indígenas estavam encontrando dificuldades para a sua implementação e o assunto foi objeto de identificação pela alta administração federal. Havia obstáculos à implementação dessas políticas públicas diante de confronto com outras, relativas à segurança nacional, à área ambiental e à de reforma agrária.

A AGU, diante da competência prevista no art. $131^{16}$, da Constituição Federal, dentre as quais se insere o assessoramento e a consultoria jurídica do Poder Executivo Federal, recebeu a demanda, originária da Presidência da República, para a solução da controvérsia administrativa, incumbência que o Advogado-Geral da União delegou ao Consultor-Geral da União, por pertinência, a quem incumbiu a tarefa de coordenar um Grupo de Trabalho, composto dos seguintes Órgãos e Entidades:

- Advocacia-Geral da União, contando com integrantes da Consultoria-Geral da União (CGU-AGU), Procuradoria Geral da União (PGU-AGU) (especialmente representada pelo Departamento de Patrimônio e Probidade (DPP-PGU-AGU)), Procuradoria Geral Federal (PGF-AGU) e Secretaria Geral de Contencioso (SGCTAGU)

- Presidência da República:

- Gabinete de Segurança Institucional (GSI) ${ }^{17}$

- Secretaria Especial de Direitos Humanos (SDH) ${ }^{18}$

- Secretaria Especial de Políticas de Promoção da Igualdade Racial (Seppir) (especialmente representada pela Subsecretaria de Políticas para Comunidades

\footnotetext{
${ }^{16}$ Art. 131. A Advocacia-Geral da União é a instituição que, diretamente ou através de órgão vinculado, representa a União, judicial e extrajudicialmente, cabendo-lhe, nos termos da lei complementar que dispuser sobre sua organização e funcionamento, as atividades de consultoria e assessoramento jurídico do Poder Executivo.

$\S 1^{\circ}$ - A Advocacia-Geral da União tem por chefe o Advogado-Geral da União, de livre nomeação pelo Presidente da República dentre cidadãos maiores de trinta e cinco anos, de notável saber jurídico e reputação ilibada.

$\S 2^{\circ}$ - O ingresso nas classes iniciais das carreiras da instituição de que trata este artigo far-se-á mediante concurso público de provas e títulos.

$\S 3^{\circ}$ - Na execução da dívida ativa de natureza tributária, a representação da União cabe à Procuradoria-Geral da Fazenda Nacional, observado o disposto em lei.

${ }^{17}$ O Gabinete de Segurança Institucional teve a sua constituição revista pela Lei n ${ }^{\circ} 13.266,5$ de abril de 2016.

18 A Secretaria de Direitos Humanos e a Secretaria Especial de Políticas de Promoção da Igualdade Racial também tiveram a constituição revista pela Lei $n^{\circ} 13.266,5$ de abril de 2016, e pela Medida Provisória $n^{\circ}$ 696, de 12 de maio de 2016, convertida na Lei n 13.341, de 29 de setembro de 2016.
} 
Tradicionais))

- Subchefia de Análise e Acompanhamento de Políticas Governamentais da Casa Civil (SAG)

- Subchefia de Assuntos Jurídicos da Casa Civil (SAJ)

- Ministério da Defesa (MD)

- Ministério do Desenvolvimento Agrário (MDA) ${ }^{19}$

- Instituto Nacional de Colonização e Reforma Agrária (Incra)

- Ministério da Justiça (MJ)

- Fundação Nacional do Índio (Funai)

- Ministério do Meio Ambiente (MMA) ${ }^{20}$

- Instituto Chico Mendes de Conservação da Biodiversidade (ICMBio)

- Instituto Brasileiro do Meio Ambiente e dos Recursos Naturais Renováveis (Ibama)

- Ministério do Planejamento, Orçamento e Gestão (MP)

- Secretaria de Patrimônio da União (SPU)

- Ministério da Cultura (MinC)

- Fundação Cultural Palmares (FCP)

- Instituto do Patrimônio Histórico e Artístico Nacional (Iphan)

A tarefa recebida pelo Grupo de Trabalho foi a identificação dos problemas existentes, causadores de controvérsias administrativa entre órgãos e entidades da administração federal, causadores de empecilhos ao implemento das políticas públicas traçadas em prol de remanescentes de comunidades de quilombos e de populações indígenas, visando à apresentação de sugestões para a solução da problemática.

Após a abertura dos trabalhos, em 25 de julho de 2007, com a coordenação do Advogado-Geral da União, as atividades foram delegadas ao Consultor-Geral da União, restando estabelecido o seguinte procedimento para os trabalhos: todos representantes de órgãos e entidades componentes do grupo de trabalho teriam oportunidade de uma primeira

\footnotetext{
${ }^{19}$ O Ministério de Desenvolvimento Agrário e o Ministério da Justiça também passaram por transformações com o advento da Medida Provisória ${ }^{\circ}$ 696, de 12 de maio de 2016, convertida na Lei n 13.341, de 29 de setembro de 2016.

${ }^{20}$ Em 14 de setembro de 2007, houve o engajamento no Grupo de Trabalho por parte do Serviço Florestal Brasileiro, resultado de desconcentração no Ministério do Meio Ambiente.
} 
manifestação verbal, em reunião, traçando as linhas gerais dos pontos divergentes, mediante a separação dos dois temas quilombola e indígena e, posteriormente, todos deveriam encaminhar as propostas detalhadamente, por escrito, por meio eletrônico, à ConsultoriaGeral da União (CGU-AGU), a fim de que um sub-grupo de trabalho, instituído entre a CGU-AGU e a Casa Civil (Subchefia de Análise e Acompanhamento de Políticas Governamentais (SAG) e Subchefia de Assuntos Jurídicos (SAJ)), promovesse a análise e consolidação das propostas, visando ao encaminhamento das soluções.

No dia 31 de julho de 2007, houve a primeira reunião acerca da questão indígena, adotando-se o mesmo procedimento antes descrito, mas esta parte dos trabalhos deixa de ser aqui relatada, porque não integra o objeto da pesquisa.

Dando sequência à exposição dos integrantes quanto à questão quilombola, ocorreu a segunda reunião em dia 2 de agosto de 2007, quando foram concluídas as abordagens gerais. Ficou estabelecido o prazo limite de 9 de agosto de 2007, para as contribuições escritas, por meio eletrônico.

A partir do encerramento das reuniões do grupo pleno, seguiram-se diversas reuniões de trabalho do sub-grupo de sistematização, para a análise e sistematização das propostas recebidas.

Houve o compartilhamento dos temas, com a instituição de um cronograma de trabalho, prevendo, inicialmente o encerramento da análise técnica quanto à questão quilombola, para o posterior estudo quanto à questão indígena.

\section{A Questão Quilombola}

O art. 68 do Ato das Disposições Constitucionais Transitórias prevê que aos "remanescentes das comunidades dos quilombos que estejam ocupando suas terras é reconhecida a propriedade definitiva, devendo o Estado lhes emitir os títulos respectivos.". Tal dispositivo foi regulamentado pelo Decreto $n^{\circ} 4.887$ (BRASIL, 2003), e este foi objeto de Ação Direta de Inconstitucionalidade (ADI) no 3.239, ajuizada em 25 de junho de 2004, pelo Partido Democratas, questionando, em síntese: a regulamentação do dispositivo constitucional por decreto, por invasão de competência legal; a criação de nova modalidade de desapropriação; o critério de fixação da auto-atribuição das comunidades quilombolas; e 
a possibilidade de que os dados para delimitação territorial tomassem como base referências da comunidade solicitante.

O inciso III do art. $2^{\circ}$ da Lei $n^{\circ} 7.668$ (BRASIL, 1998) fixara competência para a Fundação Cultural Palmares (FCP) realizar a identificação dos remanescentes das comunidades dos quilombos, proceder ao reconhecimento, à delimitação e à demarcação das terras por estes ocupadas e conferir-lhes a correspondente titulação.

Nada obstante tenha mantido a competência da FCP para a certificação das comunidades quilombolas, o Decreto $n^{\circ} 4.887$, (BRASIL, 2003), fixou, em seu art. $3^{\circ}$, a competência do Instituto Nacional de Colonização e Reforma Agrária (Incra), para a respectiva titulação na terra:

Art. $3^{\circ}$ Compete ao Ministério do Desenvolvimento Agrário, por meio do Instituto Nacional de Colonização e Reforma Agrária - INCRA, a identificação, reconhecimento, delimitação, demarcação e titulação das terras ocupadas pelos remanescentes das comunidades dos quilombos, sem prejuízo da competência concorrente dos Estados, do Distrito Federal e dos Municípios.

$\S 1^{\circ} \mathrm{O}$ INCRA deverá regulamentar os procedimentos administrativos para identificação, reconhecimento, delimitação, demarcação e titulação das terras ocupadas pelos remanescentes das comunidades dos quilombos, dentro de sessenta dias da publicação deste Decreto.

$\S 2^{\circ}$ Para os fins deste Decreto, o INCRA poderá estabelecer convênios, contratos, acordos e instrumentos similares com órgãos da administração pública federal, estadual, municipal, do Distrito Federal, organizações não-governamentais e entidades privadas, observada a legislação pertinente.

$\S 3^{\circ} \mathrm{O}$ procedimento administrativo será iniciado de ofício pelo INCRA ou por requerimento de qualquer interessado.

$\S 4^{\circ} \mathrm{A}$ autodefinição de que trata o $\S 1^{\circ}$ do art. $2^{\circ}$ deste Decreto será inscrita no Cadastro Geral junto à Fundação Cultural Palmares, que expedirá certidão respectiva na forma do regulamento. 
A controvérsia administrativa, nesta pesquisa entendida e denominada de litigância intragovernamental foi instaurada na alta administração por detecção de que pedidos de regularização fundiária de comunidades quilombolas (assim como as de comunidades indígenas) configurariam, especialmente, a sobreposição geográfica com áreas identificadas como de segurança nacional, no âmbito do Conselho de Defesa Nacional ${ }^{21}$ ou como de unidades de conservação, pelo Ministério do Meio Ambiente ${ }^{22}$.

A metodologia definida para as atividades do grupo de trabalho coordenado pela AGU, sob o comando do Consultor-Geral da União pressuponha que cada órgão antes identificado como seu componente encaminhasse as suas considerações sobre o conflito estabelecido, a fim de que pudessem ser avaliadas, pelo sub-grupo de consolidação, e, ato subsequente, as propostas de solução a seriam compartilhadas para a deliberação plenária.

Do trabalho do sub-grupo, que avaliou todas as análises promovidas pelos órgãos integrantes do grupo de trabalho, restou a conclusão quanto à conveniência de elaboração de diversos documentos, que promovessem o registro das sugestões e do seu cotejo com os atos normativos dispostos.

Desta forma, o sub-grupo levou ao grupo pleno a sugestão de alterar a Instrução Normativa (IN) Incra $n^{\circ} 20$ (BRASIL, 2005) mediante nova redação que encamparia as sugestões do conjunto, além da instituição de um documento, que consolidaria todas as medidas gerenciais enumeradas pelo sub-grupo de síntese, com fundamento das manifestações dos participantes.

O encaminhamento de maior relevo para o direcionamento dos trabalhos foi destacar os pontos de possível convergência entre as manifestações, buscando identificar aspectos em que a construção do consenso contemplasse uniformidade entre as medidas no âmbito da administração federal.

Por exemplo, o pronunciamento quanto à não alteração do Decreto $\mathrm{n}^{\circ} 4.887$, (BRASIL, 2003) guardou coerência com a defesa da administração estabelecida perante o Supremo Tribunal Federal (STF).

Encerrados os trabalhos preliminares do sub-grupo de síntese, houve uma reunião em 10 de setembro de 2007, para a apresentação dos resultados de seus trabalhos. Os

${ }^{21} 1^{\circ}$ do art. 91, da Constituição Federal e Decreto n ${ }^{\circ} 8.183$, de 11 de abril de 1991.

${ }^{22}$ Inciso VXI do art. 27 da Lei ${ }^{\circ} 10.683$, de 28 de maio de 1983, e Lei ${ }^{\circ}{ }^{9} .985$, de 18 de julho de 2000. 
documentos elaborados a seguir descritos, foram compartilhados com todo o conjunto, por meio eletrônico, na mesma data:

- quadro comparativo e sintético de todas as manifestações;

- redação do Decreto $n^{\circ} 4.887$ (BRASIL, 2003), com a inserção de todas as sugestões oferecidas, no sentido de sua alteração, mediante a utilização de cores de fontes diversas, uma para cada proponente;

- redação da IN Incra $n^{\circ} 20$ (BRASIL, 2005) com a inserção de todas as sugestões oferecidas, no sentido de sua alteração, mediante a utilização de cores de fontes diversas, uma para cada proponente;

- quadro comparativo entre a IN e o Decreto; e

- quadro comparativo da IN com a Portaria no 14 (BRASIL, 1996) do Ministério da Justiça, que trata da titulação para populações indígenas; e

- quadro sintético das propostas de medidas gerenciais.

Houve, na mesma oportunidade designação de uma reunião em 14 de setembro de 2007, interregno durante o qual os participantes analisaram a conclusão dos trabalhos do sub-grupo, visando ao encaminhamento de manifestações, que deveria ocorrer na nova reunião.

Realizada a primeira reunião de consolidação final, fez-se necessário o prosseguimento dos trabalhos por mais duas datas, 19 e 20 de setembro de 2007 , momento em que foi concluída a análise.

No dia seguinte, 21 de setembro de 2007, foi remetido a todos os colaboradores o novo texto de instrução normativa do Incra, a ser submetido aos titulares dos órgãos e entidades, para colheita de suas manifestações, visando à efetiva conclusão dos trabalhos do grupo, no tocante à questão quilombola. O mesmo procedimento de trabalho foi adotado quanto à questão indígena.

Em apertada síntese, o grupo de trabalho entendeu que para solucionar as divergência identificadas quanto à implementação das políticas públicas destinadas a comunidade quilombolas convinha manter inalterado o Decreto $\mathrm{n}^{\circ} 4.887$ (BRASIL, 2003), considerando o seu valor, decorrente do amplo debate que sua redação ensejou, por mais de dois anos, 
junto à Casa Civil da Presidência da República, bem assim a reflexão de que seu conteúdo, embora objeto de impugnação através de ADI, recebeu favorável crivo em parecer do Ministério Público Federal.

Desta forma, a alteração da IN Incra n 20 (BRASIL, 2005), mantendo a íntegra dos nortes estabelecidos no Decreto, especialmente quanto aos marcos conceituais, inalterados, teve como escopo a fixação de parâmetros para aperfeiçoamento do procedimento fixado para a titulação das remanescentes de comunidades de quilombos, ao mesmo tempo em que contemplou o resguardo aos diferentes interesses de Estado que guardam interface com a execução da política pública em relevo, cabendo referir que dizem respeito a aspectos de mesmo relevo constitucional, quais sejam questões de segurança nacional, de interesses indígenas, e de natureza ambiental. Com o estabelecimento de maior interação entre os órgãos e entidades, que passarão a atuar conjuntamente, ficariam reduzidas as possibilidades de conflitos administrativos obstarem a implementação das políticas públicas.

Por cautela, contudo, caso divergências houvesse, restou prevista a existência de instâncias administrativas, para eficiente solução, dependendo do cerne da controvérsia estabelecida: se políticas, com interferência da Casa Civil; se jurídica, por atuação da AGU.

No espectro de aperfeiçoamento do procedimento para a titulação quilombola, merece especial referência a instituição de um rito criterioso para a confecção do Relatório Técnico de Identificação e Delimitação (RTID), com a atribuição de diversos critérios, de natureza objetiva, aliado à ampliação das condições de divulgação do procedimento, do prazo para interposição de recursos e da possibilidade de resguardo dos direitos das comunidades, mediante a notificação da FCP, acerca das decisões a serem proferidas.

Antecipando-se à conclusão das atividades do grupo de trabalho, a FCP providenciou a revisão do ato normativo disciplinador do procedimento de certificação das comunidades auto-identificadas e publicou a Portaria $n^{\circ} 98$ (BRASIL, 2007).

A conclusão da parte técnica dos trabalhos do grupo, quanto à questão quilombola já antecipou a clara possibilidade de solução do problema trazido à solução.

Em 24 de setembro de 2007, das 14 h às 20 h e $40 \mathrm{~min}$, parte do sub-grupo de consolidação esteve presente à audiência pública, instalada no Auditório Nereu Ramos, na Câmara dos Deputados, com a presença de aproximadamente 600 (seiscentos) quilombolas de todo o País. Compuseram a mesa, além do Consultor-Geral da União, Ronaldo Jorge de 
Araujo Vieira Junior, a Subprocuradora-Geral da República Deborah Duprat, Coordenadora da $6^{\text {a }}$ Câmara do Ministério Público Federal (MPF), que convocou a audiência, o Deputado Domingos Dutra, do PT(MA), o Deputado Luiz Alberto, da Secretaria de Promoção da Igualdade do Estado da Bahia, o Presidente do Incra Rolf Hackbart, o Presidente da FCP, Zulu Araújo, a representante da Secretaria Especial de Políticas de Promoção da Igualdade Racial (Seppir), Givânia Silva, a Sra. Jô Brandão, integrante da Coordenação Nacional das Comunidades Negras Rurais Quilombola (Conaq), o representante do o Min. do Desenvolvimento Social e Combate à Fome (MDS) Aderval Costa Filho, o Secretário de Extrativismo e Desenvolvimento Rural Sustentável, do Ministério do Meio Ambiente (MMA), Egon Krakhecke, e a Assessora do Ministro do Desenvolvimento Agrário (MDA) Renata Leite.

Adotou-se como procedimento de trabalho a manifestação preliminar dos integrantes do movimento quilombola, para perguntas dirigidas aos componentes da mesa. Houve longa fila para o uso da palavra, de maneira que, exceto por alguns esclarecimentos, preliminares da mesa, a palavra esteve franqueada, por ordem de inscrição, para os quilombolas, do início dos trabalhos, até às $18 \mathrm{~h} 40 \mathrm{~min}$.

Esta conduta de possibilitar a manifestação dos integrantes do movimento quilombola se demonstrou essencial para que se conseguisse em todos os momentos o estabelecimento do diálogo com esta representação social e nas falas sempre se mencionou a necessidade de falar e de ser ouvido. Em alguns momentos o pronunciamento até foi centrado neste aspecto: falar porque precisava ser ouvido.

Este ponto tem relevo para o presente trabalho, à medida em que a literatura pesquisada tende a pontuar o requisito da expressão democrática na possibilidade da expressão social. Mas, assim como evidencia a teoria, a ânsia pela fala comporta a expectativa de que produza efeitos prático nas deliberações a serem produzidas.

Os quilombolas insurgiram-se de forma veemente contra a proposição, pelo Deputado Valdir Colatto, do PSDB (SC), do Projeto de Decreto Legislativo $\mathrm{n}^{\mathbf{o}}$ 044, (BRASIL, 2007), com o objetivo de promover a suspensão do Decreto $n^{\circ} 4.887$, (BRASIL, 2003).

Ainda que sempre se manifestassem em profunda insatisfação com as políticas públicas que lhes eram destinadas, a esta população quilombola em muito inquietava o risco 
de retrocessos às conquistas já contabilizadas, entre as quais listavam a publicação do decreto em relevo, responsável por regulamentar o ADCT.

Em síntese, o Presidente da FCP esclareceu que a alteração da Portaria regente da certificação quanto à auto-atribuição decorreu, em momento próximo e antecedente àquela audiência pública teria tido origem especialmente de recomendação do Ministério Público Federal, no Estado da Bahia, posterior à divulgação, em mídia nacional, através da Rede Globo de Televisão, sobre equívocos na emissão de certidão de auto-atribuição. Naquela oportunidade, a Portaria estava pronta para publicação, pendendo apenas da revisão de texto.

Diante dessa informação e em cotejo com as posições definidas pela coordenação da Sexta Câmara (Minorias) do Ministério Público Federal, alguns dos representantes quilombolas presentes à audiência pública propugnaram quanto à necessidade de uma posição uniforme por parte do MPF quanto ao trato de suas questões.

Foram divulgados, pelo movimento quilombola dois eventos ativistas, previstos para 5 de outubro, denominados "A gente não se vê por aqui", como protesto à matéria antes referida, e em 8 de novembro, encetando uma luta pela terra.

A Subprocuradora-Geral da República Deborah Duprat destacou que a AGU havia estabelecido o entendimento quanto à aplicação da Convenção OIT $n^{\circ} 169$, determinante ausculta das comunidades quilombolas em antecedência à implementação de políticas públicas que as consignassem como destinatárias e que o então dirigente máximo da AGU, Advogado-Geral da União Dias Toffoli, quando ocupando cargo junto à Casa Civil, recebera o MPF e acolhera as manifestações da Instituição, quanto às impropriedades jurídicas contidas no normativo precedente ao Decreto $\mathrm{n}^{\circ} 4.887$ (BRASIL, 2003) de maneira que o Poder Executivo Federal tenha vindo a encaminhar as medidas necessárias à edição deste.

A representante da Seppir Givânia Silva e o representante da FCP, Zulu Araújo, confirmando haver participado de reuniões do grupo de trabalho coordenado pela AGU, ratificaram a manifestação do Consultor-Geral da União, quanto ao esforço despendido, no sentido de que os trabalhos se encaminhassem visando à eliminação dos entraves administrativos configurados empecilhos à implementação das políticas públicas do Estado para a questão quilombola.

O então titular da FCP, Zulu Araújo, observou que a AGU seria uma significativa colaboração para o deslinde dos problemas enfrentados. O presidente do Incra, Rolf 
Hackbart, nada obstante comentando que não vinha participado do grupo de trabalho, declarou estar informado de seus encaminhamentos e de acordo com as suas deliberações, declarando, especialmente, ser necessária mesmo a revisão da IN Incra no 20 (BRASIL, 2005) da Autarquia e que já teria manifestado, em acordo com o respectivo Ministro, seu aval à iniciativa da AGU.

A representante do MDA Renata Leite, propôs que o Movimento agendasse uma reunião com o respectivo Ministro, sugerindo a elaboração de uma pauta preliminar.

A Sra. Jô Brandão solicitou que a consulta pública quanto à alteração da IN fosse encaminhada a todos os estados. A Suprocuradora-Geral do MPF Deborah Duprat propôs que o movimento quilombola pleiteasse uma audiência com o Ministro Cezar Peluso, Relator da $\operatorname{ADI~n} n^{\circ} 3.239$, ajuizada em face do Decreto $n^{\circ} 4.887$ (BRASIL, 2003).

Em 25 de setembro, houve o encaminhamento de mensagem eletrônica, a todos os integrantes do Grupo de Trabalho sobre Indígenas e Quilombolas, solicitando o encaminhamento das manifestações dos titulares das pastas respectivas até às 18 h de 27 de setembro de 2007.

Apresentaram manifestações, em resposta: Ministério da Justiça (MJ), Fundação Cultural Palmares, Ministério do Meio Ambiente (MMA), Instituto Brasileiro de Recursos Naturais Renováveis (IBAMA), Instituto Chico Mendes de Conservação da Biodiversidade (ICMBio), Serviço Florestal Brasileiro (SFB), Gabinete de Segurança Institucional (GSI), Instituto Nacional de Colonização e Reforma Agrária (Incra), Ministério do Desenvolvimento Agrário (MDA), Secretaria de Patrimônio da União (SPU), Fundação Nacional do Índio (Funai) e Secretaria Especial de Política de Promoção da Igualdade Racial (Seppir).

O sub-grupo de síntese, reunido em 4 de outubro de 2007, apreciou cada uma das manifestações de inovação do texto encaminhado, proferindo as deliberações consignadas em documento próprio, contendo o registro motivado de cada deliberação, dentre as quais a elaboração de um novo quadro de medidas gerenciais, contemplando apenas as questões remanescentes do trabalho desenvolvido pelo grupo.

Ao entender concluída esta fase dos trabalhos, relativamente à questão quilombola, o sub-grupo organizou a coleção de todos os documentos relacionados, para submissão ao Advogado-Geral da União. Restaram como instrumentos de trabalho constantes do processo: 
(1) o conjunto das propostas de solução, remetidas pelos órgãos e entidades; (2) cópias peças judiciais sobre demandas em curso, remetidas pela Procuradoria-Geral da União (PGUAGU); e (3) levantamento dos dados da Câmara de Conciliação e Arbitragem da Administração Federal (CCAF-CGU-AGU), sobre os processos em andamento tendo como tema as questões indígenas e quilombolas.

Para prosseguimento dos trabalhos, no tocante à questão indígena, foi convocado o sub-grupo de síntese para uma reunião em 9 de outubro de 2007, às 9 h, o que não se detalha neste trabalho, devido ao seu foco na questão quilombola.

As propostas consolidadas pelo sub-grupo, sobre os assuntos indígenas e quilombolas e os encaminhamentos do grupo de trabalho foram compartilhados entre os seus integrantes, para aprovação em cada ministério e autarquia, considerando que haveria reunião ministerial em que os temas seriam abordados. Estaria encerrada a parte técnica do trabalho de conciliação interinstitucional referente às abordagens administrativas quanto às questões controvertidas no tocante à implementação das políticas públicas em benefício de comunidades quilombolas e indígenas.

Referendados os resultados do grupo de trabalho internamente em todos os órgão e entidades representados, em 6 de novembro de 2007, o Advogado-Geral da União e o Consultor-Geral da União, em reunião no Palácio do Planalto, apresentaram ao Presidente da República e aos Ministros da Casa Civil, Justiça, Defesa, Desenvolvimento Agrário, Meio Ambiente, Planejamento, Seppir e GSI, os resultados do grupo de trabalho. No que respeita à questão quilombola: novo texto para IN Incra nº 20 (BRASIL, 2005), proposta de medidas gerenciais, quadro comparativo Decreto $n^{\circ} 4.883$ (BRASIL, 2003), IN Incra $n^{\circ} 20$ (BRASIL, 2005), quadro comparativo entre a Portaria FCP nº 06 (BRASIL, 2004) e a minuta para sua alteração $^{23}$. Relativamente à questão indígenas, novo texto para a Portaria $n^{\circ} 14$ (BRASIL, 1996), do Ministério da Justiça, e propostas gerenciais.

As autoridades indicadas aprovaram os resultados do grupo de trabalho, com algumas ressalvas pontuais, e anuíram, conforme propusera a Advocacia-Geral da União, com o encaminhamento dos instrumentos jurídicos à consulta pública prevista na Convenção

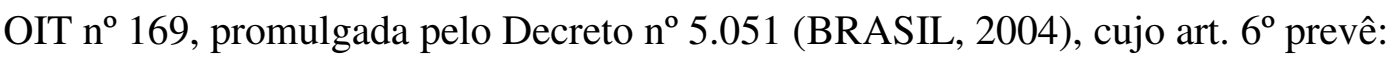

\footnotetext{
${ }^{23}$ Referência à proposta de alteração da Portaria FCP 6 (BRASIL, 2004), pela consequente Portaria FCP n 98 (BRASIL, 2007), editada no curso das atividades do grupo de trabalho.
} 
Artigo $6^{\circ}$

1 Ao aplicar as disposições da presente Convenção, os governos deverão:

a) consultar os povos interessados, mediante procedimentos apropriados e, particularmente, através de suas instituições representativas, cada vez que sejam previstas medidas legislativas ou administrativas suscetíveis de afetá-los diretamente;

b) estabelecer os meios através dos quais os povos interessados possam participar livremente, pelo menos na mesma medida que outros setores da população e em todos os níveis, na adoção de decisões em instituições efetivas ou organismos administrativos e de outra natureza responsáveis pelas políticas e programas que lhes sejam concernentes;

c) estabelecer os meios para o pleno desenvolvimento das instituições e iniciativas dos povos e, nos casos apropriados, fornecer os recursos necessários para esse fim.

2. As consultas realizadas na aplicação desta Convenção deverão ser efetuadas com boa fé e de maneira apropriada às circunstâncias, com o objetivo de se chegar a um acordo e conseguir o consentimento acerca das medidas propostas.

De imediato, as alterações apresentadas foram efetivadas. Foram expedidas, após deliberação coletiva no grupo de trabalho, correspondências a todos representantes de Comunidades Quilombolas cadastrados junto aos órgãos e entidades da administração federal representados no grupo de trabalho, tendo como anexo o texto final da minuta de norma apta a substituir a IN Incra $n^{\circ} 20$ (BRASIL, 2005), e os encaminhamentos foram integralmente comunicados ao MPF.

Diversas instituições, versadas na questão de interesses de minorias, inclusive a Coordenação Nacional de Articulação das Comunidades Negras Rurais Quilombolas (Conaq) insurgiram-se contra a consulta deflagrada pelo grupo de trabalho e seus representantes não compareceram às reuniões previstas para os dias 10 e 17 de dezembro de 2007, consoante convite formulado através do Ofício-circular nº5/2007-CGU/AGU, de 29 de novembro de 2007, encaminhado por sedex e por mensagem eletrônica. 
O Consultor-Geral da União persistiu no esforço para o estabelecimento de comunicação com o movimento quilombola e designou reunião com o grupo de trabalho, para 19 de dezembro de 2007. Indispensável observar a presença na reunião da Subprocuradora-Geral da República Deborah Duprat, então Coordenadora da Sexta Câmara de Coordenação e Revisão do MPF, responsável pela coordenação, integração e revisão da atuação judicial e extrajudicial na matéria populações indígenas e comunidades tradicionais, e que a integrante do Ministério Público Federal observou que o procedimento de consulta pública inaugurado pela AGU encontrava pertinência com a previsão contida na Convenção OIT n ${ }^{\circ} 169$, entendimento este firmado em evento nacional do Ministério Público Federal.

A Conaq obteve, na mencionada reunião, da coordenação do grupo de trabalho o prazo até 15 de janeiro de 2008, para apresentação de sua proposta de execução da consulta pública prevista pelo art. $6^{\circ}$, da Convenção OIT no 169 , limite prorrogado, a pedido, até 11 de fevereiro de 2008.

Em 15 de fevereiro de 2008, a Conaq apresentou a manifestação denominada "préproposta do movimento quilombola para o processo de consulta sobre as alterações da IN $n^{\circ}$ 20". O documento sugeria o seguinte procedimento de consulta pública, embora ressalve que os seus detalhes poderiam ser delineados na primeira reunião do novo grupo de trabalho a ser criado, acaso aceita tal manifestação:

- constituição de um grupo de trabalho para a coordenação do processo de consulta, composto por representantes de governo afetos à questão e representantes quilombolas;

- realização de um seminário nacional sobre os conflitos, entraves e perspectivas para a regularização fundiária das terras de quilombos, com a participação de organizações quilombolas, órgãos de governo, entidades parceiras e convidadas;

- reunião com a coordenação nacional ampliada e o grupo de trabalho, para a elaboração de um documento base (pré-proposta) para a consulta;

- reuniões ampliadas das coordenações nos estados para socializar a pré-proposta e fazer um debate inicial;

- realização de duas plenárias regionais: (1) norte/nordeste; (2) sul/sudeste/centro oeste; para debater a pré-proposta; 
- reunião de trabalho para sistematização dos trabalhos obtidos nas plenárias regionais;

- realização de duas audiências públicas nacionais: uma com as organizações quilombolas e o governo e outra mais ampla com quilombolas, parceiros e convidados.

Por determinação do Consultor-Geral da União, todos os Integrantes do grupo de trabalho, coordenado pela Consultoria-Geral da União, foram destinatários do texto em alusão, para manifestação. A FCP, através de sua Diretoria de Proteção do Patrimônio AfroBrasileiro, fez pronunciamento favorável à proposta da Conaq.

Nova reunião do grupo de trabalho foi convocada, para a deliberação quanto ao formato da consulta, quando a Seppir apresentou um novo modelo, proveniente de tratativa com o movimento quilombola e acolhido pelo grupo de trabalho: realização de dois seminários regionais, um sul/sudeste ( $1^{\circ}$ e 2/04/2008) e outro norte/nordeste/centro-oeste (3 e 4/04/2008), reuniões de sistematização, de 7 a 9/04/2008, para resumo das oitivas anteriores, e uma reunião de apresentação, em 10/04/2008, ambas em Brasília e com a participação de representantes do movimento quilombola.

Seguindo as deliberações, a Seppir, o MDA e o Incra promoveram reunião, em 24 de março de 2008, com o movimento quilombola, para traçar o planejamento da consulta pública $^{24}$.

Nova reunião do grupo de trabalho foi convocada para 27 de março de 2008, com o objetivo de avaliação dos resultados da reunião de 24 de março de 2008, considerando uma alteração de cronograma e a premência do tempo, já descrita em diversos documentos, devido à conclusão dos autos da ADI no 3.239 ao Sr. Ministro Relator, perante o STF. O grupo de trabalho aprovou a alteração de cronograma e fixou as diretrizes básicas da consulta pública, sendo relevante descrever o foco nos seguintes aspectos:

- Pressuposto do novo texto da IN, como documento base, artigo por artigo, contemplando o quadro comparativo do Decreto e os textos da IN, vigente e o proposto pelo GT, prevendo-se 30 minutos, em média, para cada dispositivo;

- Prevalência de foco deve ser o debate do texto, sem digressão em palestras, devido à premência do tempo;

\footnotetext{
${ }^{24}$ Anexo III - Memória da Reunião Preparatória para a Consulta à nova IN/INCRA
} 
- Considerando que são três dias de reuniões, com oito horas diárias e um total de 24 horas, estas devem ser bem aproveitadas para a finalidade prevista. Com a distribuição de tempo médio de 30 minutos para cada dispositivo, com um "excedente" de 8 (oito) horas que poderia ser destinado ao debate dos dispositivos mais polêmicos;

- Previsão de três hipóteses de resultados para a consulta pública: (1) manutenção dos dispositivos, (2) alteração total ou parcial dos dispositivos, quando se formar consenso GT - movimento quilombola e (3) apresentação das manifestações do movimento quilombola não admitidas pelo GT;

- Instituição de mais duas colunas no quadro comparativo, com a seguinte finalidade: quarta coluna - para registro na redação do texto do GT, com as sugestões do movimento quilombola, que forem admitidas, integral ou parcialmente, durante a reunião, e quinta coluna - para consignação das observações, sugestões, pleitos do movimento quilombola que o GT entendesse não adequadas para acréscimo ao texto trabalhado;

- Os trabalhos serão encaminhados na sequiência leitura dos dispositivos, com o oferecimento, na forma de solicitação, da palavra, para as manifestações do movimento quilombola, seguida dos pronunciamentos livres dos Integrantes do GT, para contraponto ou anuência, e concatenação das idéias, para registro na quarta ou na quinta coluna do quadro comparativo, conforme os entendimentos que se estabeleçam;

- Na medida do possível, solicitar aos representantes das comunidades que já tragam para a consulta pública as idéias centrais de suas impugnações, com o objetivo de facilitar os encaminhamentos, facilitando, sobremaneira, os debates e a sistematização;

- Concluída a leitura, discussão, análise e registros nas quarta e quinta colunas, haveria um texto pronto para o sub-grupo de sistematização, composto do GT e alguns representantes do movimento quilombola, conforme já deliberaram em reunião de 24 de março, com a Seppir.

- Finalmente, visando ao desenho da metodologia de trabalho a ser desenvolvida para a efetivação da consulta pública, quanto à divisão de tarefas entre os componentes 
do grupo de trabalho, houve uma reunião em 9 de abril de 2008, no auditório da Escola da AGU, encontro dividido em duas partes: uma interna, com os objetivos antes descritos e outra, contando com a participação dos integrantes do movimento quilombola, Srs. Damião Braga S. Santos e Oriel Rodrigues, para os quais houve a explanação do procedimento de trabalho que deveria ser adotada durante a consulta pública, deliberações cujo registro encontra-se convertido em ata constante destes autos.

Nos dias 15 a 17 de abril de 2008, no Centro de Treinamento Educacional da Confederação Nacional dos Trabalhadores na Indústria, em Luziânia (GO), houve o encontro entre os Integrantes do Movimento Quilombola e os componentes do grupo de trabalho.

As despesas decorrentes dos deslocamentos e estada dos Integrantes do movimento quilombola foram arcadas pelos órgãos e entidades integrantes do grupo de trabalho, assim como a locação do auditório para a consulta pública. A AGU promoveu o registro das reuniões em vídeo e em atas, além da coleta das assinaturas dos participantes.

O movimento quilombola obteve o deferimento de participação de doze especialistas, para o seu assessoramento, para as atividades da consulta pública, havendo a administração federal arcado com as despesas decorrentes, quanto aos técnicos de outras unidades da federação.

Na manhã do primeiro dia, houve uma reunião preliminar do grupo de trabalho, para estabelecimento dos últimos detalhes da apresentação que seria promovida naquela data de abertura dos trabalhos, enquanto os Integrantes do movimento quilombola promoviam reunião interna, exclusiva.

$\mathrm{Na}$ inauguração dos trabalhos, foi distribuído a todos os participantes da consulta pública o seguinte material: (1) texto, contendo a redação do art. 68, ADCT e o Decreto ${ }^{\circ}$ 5.051 (BRASIL, 2004), que promulgou a Convenção OIT nº 169, (2) quadro comparativo entre o Decreto, a IN vigente a IN proposta, e (3) a seguinte programação (Quadro 1):

Quadro 1 - Programação da Consulta Pública das comunidades quilombolas quanto à alteração da Instrução Normativa $n^{\circ} 20$, do INCRA.

CONSULTA PÚBLICA DAS COMUNIDADES QUILOMBOLAS QUANTO À ALTERAÇÃO DA INSTRUÇÃO NORMATIVA Nº 20, DO INCRA 


\begin{tabular}{|c|c|}
\hline \multicolumn{2}{|r|}{ PROGRAMAÇÃO } \\
\hline \multicolumn{2}{|r|}{15 de abril de 2008} \\
\hline $8 \mathrm{~h}$ às $10 \mathrm{~h}$ & $\begin{array}{l}\text { Reunião de ambientação entre os representantes das comunidades } \\
\text { quilombolas }\end{array}$ \\
\hline $10 \mathrm{~h}$ às $12 \mathrm{~h}$ & $\begin{array}{l}\text { Reunião de abertura dos trabalhos, com a participação de todos os } \\
\text { representantes das comunidades quilombolas, dos especialistas indicados } \\
\text { pelas comunidades e dos integrantes do grupo de trabalho administrativo. } \\
\text { Esclarecimentos sobre a metodologia de trabalho prevista para a consulta } \\
\text { pública }\end{array}$ \\
\hline 14 às $18 \mathrm{~h}$ & $\begin{array}{l}\text { Apresentação, pelo grupo de trabalho, dos pontos centrais de alteração da } \\
\text { IN no } 20 \text {, do Incra }\end{array}$ \\
\hline 20 às $22 \mathrm{~h}$ & Reunião interna entre os representantes das comunidades quilombolas \\
\hline \multicolumn{2}{|r|}{16 de abril de 2008} \\
\hline $8 \mathrm{~h}$ às $12 \mathrm{~h}$ & Reunião interna entre os representantes das comunidades quilombolas \\
\hline 14 às $18 \mathrm{~h}$ & $\begin{array}{l}\text { Início da leitura, artigo por artigo, análise, esclarecimento e levantamento } \\
\text { das sugestões quanto aos dispositivos da proposta de IN. }\end{array}$ \\
\hline \multicolumn{2}{|r|}{17 de abril de 2008} \\
\hline 8 às $12 \mathrm{~h}$ & $\begin{array}{l}\text { Prosseguimento da leitura, artigo por artigo, análise, esclarecimento e } \\
\text { levantamento das sugestões quanto aos dispositivos da proposta de IN. }\end{array}$ \\
\hline 14 às $18 \mathrm{~h}$ & $\begin{array}{l}\text { Prosseguimento e encerramento da leitura, artigo por artigo, análise, } \\
\text { esclarecimento e levantamento das sugestões quanto aos dispositivos da } \\
\text { proposta de IN. }\end{array}$ \\
\hline \multicolumn{2}{|r|}{ OBSERVAÇÕES: } \\
\hline \multicolumn{2}{|c|}{$\begin{array}{l}\text { - Concluída a primeira etapa do procedimento, o texto elaborado seria objeto de } \\
\text { análise e deliberação de uma comissão de sistematização, composta por Integrantes } \\
\text { do GT e por representantes das comunidades quilombolas, nos dias } 18,19 \text { e } 20 \text { de } \\
\text { abril de } 2007 \text {. } \\
\text { - A comissão de sistematização foi composta de } 6 \text { (seis) representantes da } \\
\text { administração e de } 6 \text { (seis) representantes das comunidades quilombolas, devendo } \\
\text { encaminhar a conclusão dos trabalhos, à administração, até } 22 \text { de abril de } 2008 \text {. }\end{array}$} \\
\hline
\end{tabular}


Quando compareceram os componentes do grupo de trabalho para as atividades da tarde de 16 de abril de 2008, os integrantes do movimento quilombola solicitaram uma alteração de cronograma, para permanecerem em reunião interna exclusiva, o que foi deferido, com a ressalva, aceita, de que os trabalhos no dia seguinte fossem coroados pela objetividade, considerando que toda a minuta de IN deveria ser lida, discutida e analisada.

No dia 17 de abril de 2008, os componentes do GT e os integrantes do movimento quilombola se debruçaram sobre a minuta de IN e os trabalhos foram encerrados às 19 h e 2 min, com a confecção de um quadro comparativo de três colunas, contendo: (1) a minuta do GT, (2) um texto de consenso entre o GT e as sugestões do movimento quilombola e (3) o registro de todas as sugestões do movimento quilombola que não foram aceitas pelo GT.

Ficou definido que uma comissão de sistematização paritária, com doze integrantes, desde logo indicados, faria, no período de 5 a 7 de abril de 2008, a revisão e adequação do texto da coluna intermediária de maneira a consigná-lo na forma normativa a ser encaminhada à deliberação do Sr. Presidente da República.

Na data aprazada, a AGU promoveu as medidas necessárias aos deslocamentos e custeio de permanência dos integrantes do movimento quilombola, restando realizados os trabalhos na comissão de sistematização no dia 5 de maio de 2008, com um texto apto para o encaminhamento previsto.

Foram juntadas aos autos do processo administrativo respectivo todas as correspondências recebidas pela AGU, sobre o tema em relevo no relatório, final para fins de documentação adequada.

Todas as reuniões realizadas desde 25 de julho de 2007 estão registradas em atas, constantes do respectivo processo.

Configuraram anexos do relatório das atividades do grupo de trabalho:

- o quadro comparativo entre o texto do GT, o texto de consenso entre o movimento quilombola e o GT e o texto exclusivo do movimento quilombola, cujo conteúdo não propiciou o estabelecimento de consenso;

- a nova redação para as propostas gerenciais; e

- o texto exclusivo para o normativo de consenso.

Constam como anexos desta pesquisa o relatório final do grupo de trabalho, publicado no Diário Oficial da União (Anexo III), a Instrução Normativa Incra $\mathrm{n}^{\circ} 57$ 
(BRASIL 2009) (Anexo IV) e a Convenção OIT n 169 (Anexo V), para uma visão ampla dos aspectos relatados nesta pesquisa.

\section{Fatos Subsequentes}

Como resultado final do grupo de trabalho, houve a publicação da IN Incra $n^{\circ} 49$ (BRASIL, 2008), posterior e expressamente revogada e substituída pela IN Incra $\mathrm{n}^{\circ} 57$ (BRASIL, 2009), editada ad referendum do Conselho Diretor da autarquia, pela Portaria Incra-P no 315 (BRASIL, 2009). A segunda norma foi editada sem realização de consulta pública e a Advocacia-Geral da União emitiu manifestação contrária a esta providência, exatamente diante da constatação quanto ao não atendimento da formalidade em relevo.

Posteriormente, em edição de julho a dezembro de 2015, foi publicado pelo Boletim Científico do Ministério Público Federal artigo de autoria da Procuradora Regional da República Maria Luiza Grabner, sobre o direito humano ao consentimento livre, prévio e informado como proteção dos conhecimentos tradicionais.

Em 18 de abril de 2012, a ADI no 3.239 foi colocada em julgamento do STF. Após o voto $^{25}$ do Relator, Ministro César Peluso, que concluía pela procedência da Ação, a Ministra Rosa Weber ${ }^{26}$ pediu vista dos atos, na mesma data, proferindo voto pela improcedência da Ação. O Ministro Dias Toffoli pediu vista dos autos, em 8 de abril de 2015, restituindo o

${ }^{25}$ Decisão: “Após o voto do Relator, Senhor Ministro Cezar Peluso (Presidente), julgando procedente a ação para declarar a inconstitucionalidade do Decreto $n^{\circ} 4.887 / 2003$, modulando os efeitos dessa declaração, nos termos do seu voto, pediu vista dos autos a Senhora Ministra Rosa Weber. Ausentes, justificadamente, os Senhores Ministros Celso de Mello, Joaquim Barbosa e Cármen Lúcia. Falaram: pelo requerente, o Dr. Carlos Bastide Horbach; pela Advocacia-Geral da União, o Ministro Luís Inácio Lucena Adams, AdvogadoGeral da União; pelos amici curiae Associação Brasileira de Celulose e Papel-BRACELPA; Sociedade Rural Brasileira; Conferência Nacional dos Bispos do Brasil-CNBB; Estado do Paraná; Associação dos Quilombos Unidos do Barro Preto e Indaiá, Associação de Moradores Quilombolas de Santana-Quilombo Santana e Coordenação das Comunidades Negras Rurais Quilombolas de Mato Grosso do Sul; Instituto de Advocacia Racial e Ambiental-IARA e Clube Palmares de Volta Redonda-CPVR, respectivamente, o Dr. Gastão Alves de Toledo; o Dr. Francisco de Godoy Bueno; o Dr. Torquato Jardim; o Dr. Carlos Frederico Maré de Souza Filho, Procurador do Estado; o Dr. Eduardo Fernandes de Araújo; e o Dr. Humberto Adami Santos Júnior, e, pelo Ministério Público Federal, a Vice-Procuradora-Geral da República, Dra. Deborah Macedo Duprat de Britto Pereira. Plenário, 18.04.2012." (Disponível em: $<$ http://www.stf.jus.br/portal/processo/verProcessoAndamento.asp?incidente=2227157>. Acesso em: 28/12/2016).

${ }^{26}$ Decisão: “Após o voto-vista da Ministra Rosa Weber, que conhecia da ação direta e a julgava improcedente, pediu vista dos autos o Ministro Dias Toffoli. Presidência do Ministro Ricardo Lewandowski. Plenário, 25/03/2015."

(Disponível

em: $<$ http://www.stf.jus.br/portal/processo/verProcessoAndamento.asp?incidente=2227157>. Acesso em: 28/12/2016). 
processo, em $1^{\circ}$ de julho de 2015, ao novo Relator, Ministro Ricardo Lewandowski, atual Presidente da Corte. Não se registra movimento processual posterior ao descrito.

Tem-se notícia, ainda sobre a instituição ${ }^{27}$, em meados de 2013, de grupo de trabalho interministerial na Administração federal, sob a coordenação do Ministério das Relações Exteriores (MRE) e da Secretaria-Geral da Presidência da República, para a regulamentação da Consulta Prévia prevista na Convenção OIT n 169 , mas as atividades ainda estariam inconclusas.

Houve a notícia, numa das entrevistas realizadas, de que haveria uma demanda perante a Corte Interamericana de Direitos Humanos em face do Estado Brasileiro, acerca da não implementação da previsão contida no Decreto $n^{\circ} 5.051$, (BRASIL, 2004), que promulgou em território nacional a Convenção OIT n 169, mas em pesquisa detalhada realizada no sítio eletrônico ${ }^{28}$ daquela Corte, sob todas as modalidades de procedimentos, não se logrou êxito na identificação do procedimento.

A litigância não é a vontade do Estado, não decorre da configuração republicana, ou da democracia, pois nestes tudo é conciliável. O entrave está na vontade que não é do Estado, está na potencial vontade humana justificada na aparente compreensão sobre burocracia, mas que não se soergue. Não há deslinde para a litigância intragovernamental sem se prestigiar o interesse público, a sociedade e a necessidade de desenvolvimento nacional.

O olhar retrospectivo a respeito da litigância intragovernamental conflagrada sinaliza para as perspectivas perdidas devido a sua existência e como interfere como obstáculo à efetivação democrática, à medida em que a satisfação das necessidades sociais travestidas em políticas públicas, ficam emperradas.

A ausculta de gestores e o do Ministério Público a respeito do caso concreto, em entrevistas realizadas, induz reflexões e sinaliza caminhos viáveis para uma atuação inovadora em que os problemas possam efetivamente ser convertidos em desafios e oportunidades de aprimoramento da gestão, como previsto na literatura que fundamenta o planejamento gerencial. Evidencia aspectos em que se há de ater para prevenir e encaminhar

\footnotetext{
27 Disponível em: <http://www.conectas.org/pt/acoes/empresas-e-direitos-humanos/noticia/3387-notapublica-sobre-regulamentacao-da-consulta-previa>. Acesso em: 28/12/2016.

28 Disponível em: <http://www.corteidh.or.cr/cf/Jurisprudencia2/index.cfm?lang=en>. Acesso em: 28/12/2016).
} 
tais obstáculos sem novos ônus à estrutura estatal, que merece ser preservada, visando a que atenda seu fim.

Sob o enfoque do Ministério Público, por exemplo, não se justifica que as políticas públicas não tenham a máxima efetividade e a litigância gere o descumprimento do dever estatal para com a sociedade.

Não é a disputa pela observância democrática a que se sobrepõe à gestão das políticas públicas e o vislumbre crítico deve estar em constante randomização no cenário administrativo, prevenindo que o desborde de contextos outros que desviam da finalidade em disputas por espaços não condizentes com a razão de Estado, do Estado democrático de direito.

Há um ponto de relevo nessa avaliação, quando ao protagonismo que necessita ser assumido pela gestão como meio de concretização do Estado, sob os auspícios do suporte jurídico, meio para esta instrumentalização.

Com o auxílio dos mecanismos técnico-jurídicos, podem gestores aviar as soluções possíveis e factíveis ao que deve ser o seu norte. Não há de ser a norma o empecilho para a satisfação das políticas públicas, uma vez que esta as viabilizou. Tampouco a profusão normativa meramente é o caminho para a gestão eficiente, eis que tal fenômeno até hoje eloqüente nesta Nação, sequer logrou prevenir entreves ao desenvolvimento.

Menos normatização e mais gestão pode ser um caminho a trilhar. 


\section{A LITIGÂNICA INTRAGOVERNAMENTAL COMO ENTRAVE À GESTÃo}

\section{A Avaliação dos Efeitos da Litigância}

A realização de entrevistas com uma parcela de integrantes do grupo de trabalho interministerial e informal, além do então Advogado-Geral da União e a SubprocuradoraGeral da República, Coordenadora da Sexta Câmara do Ministério Público Federal, teve como objetivo conhecer a percepção sobre os trabalhos desenvolvidos e a sua repercussão no efeito objeto da pesquisa, vale dizer, a interferência dos seus resultados para a gestão de políticas públicas.

Foi eleita uma representação simbólica dos polos que indicavam o antagonismo inercial e causal para a composição do grupo de trabalho, tendo sido contatos integrantes do Incra, MMA, Seppir, Casa Civil, GSI-PR, MDA, ICMBio e FCP. Devido ao decurso do tempo, nenhuma das pessoas contatadas desenvolve as mesmas atribuições ou ocupa os postos de trabalho que motivaram as suas indicações para as atividades, exceto o membro do MPF.

O lapso temporal foi desfavorável também para os contatos havidos e a recordação pormenorizada dos fatos, mas, de uma maneira geral, configurou-se uma boa acolhida ao pedido de entrevista e as surpresas previstas na lição de BAUER e $\operatorname{GASKELL}^{29}$ (2015, p. 70) puderam ser comprovadas.

\footnotetext{
${ }^{29}$ Quantas entrevistas são necessárias?

Sob muitos aspectos, esta questão prova a resposta, "que comprimento tem uma corda?", e na realidade, a resposta é: "depende". Depende da natureza do tópico, do número dos diferentes ambientes que forem considerados relevantes e, é claro, dos recursos disponíveis. Contudo, há algumas considerações gerais que guiam a decisão. Um ponto-chave que se deve ter em mente é que, permanecendo todas as coisas iguais, mais entrevista não melhoram necessariamente a qualidade, ou levam a uma compreensão mais detalhada. Há duas razões para esta afirmação. Primeiro, há um número limitado de interpelações, ou versões, da realidade. Embora as experiências possam parecer únicas ao indivíduo, as representações de tais experiências não surgem das mentes individuais; em alguma medida, elas são o resultado de processos sociais. Neste ponto, representações de um tema de interesse comum, ou de pessoas em um meio social específico são, em parte, compartilhadas. Isto pode ser visto em uma série de entrevistas. As primeiras são cheias de surpresas. As diferenças entre as narrativas são chocantes e, às vezes, ficamos imaginando se há ali algumas semelhanças. Contudo, temas comuns começam a aparecer, e progressivamente sente-se uma confiança crescente na compreensão emergente do fenômeno. A certa altura, o pesquisador se dá conta que não aparecerão novas surpresas ou percepções. Neste ponto de saturação do sentido, o pesquisador pode deixar seu tópico guia para conferir sua compreensão, e se a avaliação do fenômeno é corroborada, é um sinal de que é tempo de parar.
} 
O formulário, constante como Anexo I, objetivava a percepção dos gestores sobre a forma de tratamento da litigância intragovernamental, especialmente com a colheita de informações quanto aos seus aspectos favoráveis ou desfavoráveis ao encaminhamento pretendido, a satisfação das políticas públicas.

Como observado acima, as entrevistas realizadas com então Advogado-Geral da União, hoje Ministro do STF; a Subprocuradora-Geral da República, Coordenadora da Sexta Câmara do Ministério Público Federal; e o então Consultor-Geral da União sofreram alguma variação, considerando que o formulário adotado se destinava aos integrantes do grupo de trabalho. O Consultor-Geral da União assumiu a coordenação, o então Advogado-Geral da União e a Subprocuradora-Geral da República tinham participação e percepção diferentes, diante do também diverso grau de envolvimento com as atividades.

Para a análise das respostas percebidas, o critério utilizado diz respeito à possibilidade de interferência favorável ou desfavorável dos resultados do grupo de trabalho no tocante à gestão de políticas públicas, contemplando, especialmente, quando for factível, a variável referente à discricionariedade da atuação administrativa.

Para esta apreciação, não foi avaliada qualquer entrevista isoladamente, mas os pontos destacados, considerando que uma mesma entrevista pode ter apreendido percepções em um ou outro sentido. A íntegra das respostas consta como Anexo II deste trabalho. Na coletânea dos aspectos a seguir apresentados, não se promove o juízo de valor quanto às afirmações coligidas, exceto para enfatizar, em algum ponto, a sua relevância para a pesquisa em curso, que tem como pergunta central, para o estudo de caso, a sua contribuição para a gestão de políticas públicas.

No último tópico deste capítulo são tecidas as observações da pesquisadora quanto as respostas apreendidas pelos entrevistados.

\section{O Desafio para a Advocacia de Estado}

A atuação da AGU na coordenação do grupo de trabalho foi vislumbrado de forma diversificada pelos entrevistados: para alguns, cabia à AGU esta função e a desenvolveu com êxito; para outros não competia, havendo isto implicado a redução do empoderamento das áreas sociais do governo, embora tenha havido um resultado final favorável, diante da 
realização da consulta pública, porque a percepção externa do governo teria ganho determinado nível de confiabilidade, sobre o que se discorrerá mais à frente.

A percepção negativa da atuação da AGU na conciliação promovida decorre do entendimento de que não se tratava efetivamente de uma litigância por razões jurídicas, mas de contexto político, uma disputa do espaço na administração que o movimento social reivindicava, mas que estava obstado pela ação de uma área mais conservadora, voltada para a questão de segurança de Estado.

Percebe-se o privilégio, nesta compreensão do entrevistado, de que a rede dialógica a ser estabelecida deveria contemplar a satisfação da política pública mediante a ausculta social e a interação entre os componentes desta ala da administração, configurando a necessidade de se prestigiar os compromissos estabelecidos com a programação política originária da ocupação do governo. Como sinalizam O’DONNELL (2011 e 2000) e DAHL, cada um com sua abordagem, ao descrever os elementos para a percepção democrática, há necessidade de manifestação posterior ao processo eleitoral, o que se detecta mediante a possibilidade do pronunciamento e a eventual capacidade de interferir nos resultados. De acordo com esses autores, quanto mais se vislumbrem presentes estes elementos (participação e interferência), de forma conjugada, mais plausível a probabilidade de evidência democrática.

Mesmo com um nível de divergência considerável, teria havido, para um entrevistado, a possibilidade de composição administrativa mínima ente a área ambiental, capitaneada por MMA, ICMBio e IBAMA, o que não era possível com a representação da área de segurança e militar, como MD e GSI. Como a controvérsia, em parte da apreciação comentada, não era entendida como jurídica, a intervenção da AGU impedia que os efetivos antagonismos, de natureza política, ficassem mais evidentes.

Segundo um entrevistado, existia uma forte demanda política por espaços constituídos, mesmo no âmbito dos órgãos que deveriam atender as políticas públicas em favor das comunidades quilombolas: Seppir, FCP, MDA e Incra. E entre estes e MMA e GSI. Com estes haveria maior gargalo. Os órgãos que atendiam as políticas públicas para as comunidades quilombolas, apesar das dificuldades de sintonia, conseguiam alguma articulação para o enfrentamento com o MMA e com o GSI principalmente. Na vigência do grupo de trabalho, Seppir, FCP, MDA e Incra faziam ajustes prévios, para enfrentarem as 
disputas com as áreas de segurança e ambiental. Nada obstante, remanesceu a sensação de falta do protagonismo pretendido.

É expressivo observar que a tendência ou predisposição ao diálogo cambia sua perspectiva de acordo com o interlocutor previsto para o debate, com cenários diferenciados para a eventual autocomposição do conflito. Esse panorama implica que a abordagem, a possível construção para a litigância deve contemplar a multiplicidade de contextos, sem fórmulas prontas, numa plasticidade evidenciada por BAUMAN (2014).

Mesmo no Incra, como relato do entrevistado, havia muitas disputas sobre a questão do fluxo de trabalho para a regularização fundiária de comunidades quilombolas porque o Incra já possuía um fluxo de trabalho para a regularização fundiária em regra, que queria aplicar às comunidades, enquanto estas consideravam que o procedimento a ser aplicado era diferenciado. Para um entrevistado, de fato, a questão só teria sido pacificada em 2008, na contemporaneidade dos trabalhos do grupo coordenado pela AGU, quando um integrante de comunidade quilombola, antes na gestão da Seppir, assumiu a Diretoria de Regularização Fundiária para Comunidades Tradicionais, no Incra, implementando as políticas públicas na concepção destas, como dito, a partir de 2008. O Incra teria resistido muito em alterar seus procedimentos de trabalho para atender de forma diferenciada as comunidades quilombolas, o que teria ensejado muita articulação interna na administração e investimento de tempo.

A insatisfação com o fato de a AGU estar coordenando os trabalhos, segundo um entrevistado, decorreria também da constatação de que a atuação desta era muito diferente da concepção de alguns gestores, distanciando-se no discurso promovido para com as comunidades quilombolas. Segundo este mesmo entrevistado, a própria norma estabelecida pelo trabalho do grupo sinalizou que as controvérsias políticas deveriam ser resolvidas no âmbito da Casa Civil e apenas a jurídica pela AGU.

Este ponto é sensível para a pesquisa em curso, à medida em que, de uma parte, gestores têm o encargo e a competência normativa para a implementação de políticas públicas e, de outra, os responsáveis pelo trabalho jurídico, no caso da administração federal, a AGU e seus órgãos vinculados, devem assessorá-los, juridicamente, a fim de resguardar a observância dos princípios constitucionais, especialmente, nesta avaliação, a legalidade. O delineamento desses limites nem sempre resulta em tratativas exitosas e há o assunto gera impactos na efetivação do Estado. 
A atuação da AGU, por ser muito técnica, segundo um entrevistado, seria a causa dessa insatisfação, além do entendimento de que a AGU não conheceria a abordagem política do assunto, porque não era a sua área de competência. A coordenação dos trabalhos pela AGU exigiu, segundo o entrevistado, que Seppir, FCP, MDA e Incra tentassem construir um consenso interno entre as áreas técnica e jurídica, para auxiliar nos encaminhamentos que se buscava dar no grupo, a fim de instituir um prévio alinhamento e dar mais agilidade às reuniões.

De acordo com um entrevistado a participação da AGU no processo acarretaria um longo período de indefinição, o que teria sido visto como outro aspecto negativo para a política pública, gerando, consequentemente, muito desgaste social.

Há abordagens diferentes para o diagnóstico do problema entre os entrevistados, eis que para alguns havia consenso na área social e, para outros, isto não existia e esta percepção diferenciada naturalmente interfere na avaliação dos resultados obtidos assim como tem, impacto, numa perspectiva de futuro, na construção de cenários possíveis para implementar a autocomposição administrativa.

Para mais um entrevistado, o Incra não atendia adequadamente, antes da constituição do grupo, as demandas das comunidades quilombolas porque as incluía na concepção comum da autarquia, do atendimento de política pública para assentamento agrário, enquanto o correto seria o tratamento diferenciado por ser indispensável o tratamento de quilombolas como comunidades tradicionais, com previsão constitucional.

Para outro esterevistado, havia equívoco do Incra, para a titulação de comunidades quilombolas, ao estar adotando os procedimentos simétricos aos da Funai, aplicável este apenas a comunidades indígenas, de maneira que estabelecia critérios de demarcação que divergiam da previsão constitucional, conduta vista como provável a inviabilizar a própria efetivação do Decreto específico para estas populações (quilombolas). Nesta concepção, a assim descrita postura exacerbada do Incra mais prejudicaria do que viabilizaria o atendimento das políticas públicas em apreço.

Nos dois contextos expressos, havia insatisfação com a forma de execução das políticas públicas e a previsão de que a AGU atuaria na solução das controvérsias jurídicas, uma das feições de litigância intragovernamental, não se demonstrou decisão bem acolhida na área social do governo, que concebia toda a divergência como de natureza política. 
Convém observar a este respeito que, na norma criada pelo grupo de trabalho constituído, foi definida a previsão de competência da AGU para o encaminhamento das controvérsias de natureza jurídica, quedando à Casa Civil a condução dos trabalhos quando detectada a divergência de cunho político.

No momento em que o grupo de trabalho desenvolvida as suas atividades ainda não havia esta construção, que decorreu de suas reflexoes, mas é relevante, cientificamente, observar que esta rejeição à participação da AGU nos procedimentos porque aponta, em certa medida, um esforço que mais tarde se demonstrará necessário para a construção de soluções dialógicas na administração pública.

Como proposto por LÚCIO e RODRIGUES (2016), a expectativa é a de que a administração se encaminhe para a autocomposição de suas disputas, equilibrando para que a solução não se consolide como um autoritarismo burocrático (O’DONNELL, 1973), em que a estrutura estatal venha a ser utilizada para olvidar a constituição democrática, perpassando seus princípios com obstáculos construídos como forma de inviabilizar o entendimento oposto e sem conexão com os interesses públicos, ainda eventualmente possa denotar interesse da administração (WEBER, 2015).

O desafio da perenidade democrática é a preservação da possibilidade de participação e de intervenção não apenas na definição da força política investida no poder, mas ao longo do processo, convertendo o antagonismo em elemento que aprimore a gestão (O’DONNELL, 2011 e HALPERN, 2014, p. 293).

Este aspecto é de especial relevo nesta pesquisa, porque o estudo de caso deixa bem evidente que a litigância intragovernamental é um percurso de duas vias - a disputa que obstaculiza a execução da política pública pode ter uma natureza eminentemente jurídica, assim como pode decorrer de um enfrentamento de viés político. Essa imbricada configuração enseja o discernimento necessário do trabalho técnico a ser promovido, a fim de que os papeis não se sobreponham, fator deletério para a erradicação do problema e, consequentemente, para a gestão das políticas públicas.

Alguns dos entrevistados recordaram que a litigância intragovernamental não se cingia à querela interna no Poder Executivo, ao se considerar que, para além do ajuizamento de ADI, pelo Partido Democratas, diante da publicação do Decreto pelo governo provido por integrantes do Partido dos Trabalhadores, tramitava no Congresso Nacional (Câmara dos 
Deputados) proposta de Decreto Legislativo para a suspensão dos efeitos do Decreto $\mathrm{n}^{\circ} 4.887$ (BRASIL, 2003).

Mais uma percepção de tom burocrático esteve vinculada ao entendimento de que a previsão de competência do Incra para a regularização fundiária de comunidades quilombolas, antes cabível à FCP, teria tido, para um dos entrevistados, o discreto intuito de fortalecimento na autarquia fundiária, justificando ou ratificando a sua razão de existir, sem que isto implicasse, efetivamente, a solução das questões conflituosas.

Para o Ministério Público, embora, preliminarmente, tenha se colocado de acordo com a consulta realizada pela AGU, por perceber no Consultor-Geral da União a expertise para respeitar e lidar com movimentos sociais, diante da configuração de bons propósitos, alterou, parcialmente, em seguida, o entendimento, por vislumbrar que o processo de consulta se realizou de uma maneira forçada, ainda que válida por ter sido a primeira iniciativa a levar a cabo o procedimento de consulta previsto na Convenção OIT n ${ }^{\circ} 169$.

As máculas identificadas no procedimento, pelo Ministério Público, por seu integrante entrevistado, estariam vinculadas à ausência de dois requisitos indispensáveis: a boa-fé do consulente e a ativa participação dos consultados. Embora se reconheça ter havido um esforço de credibilidade e de intervenção ativa das comunidades, o procedimento ainda teria deixado a desejar.

Houve menção, pelo Ministério Público, de que a vantagem da consulta pública realizada foi mais simbólica e formal, sem tenha havido o convencimento das comunidades. As propostas apresentadas não teriam encontrado o amparo devido ou sequer sido efetivamente examinadas como mereciam, de maneira que isto teria esvaziado a utilidade do procedimento.

Destacou, ainda o entrevistado do Ministério Público Federal, a ressalva ao grupo de sistematização, porque as comunidades quilombolas fizeram várias observações que não foram consideradas ao final, no texto publicado. O grupo de sistematização teria se circunscrito em anotar as divergências, sem apreciar ou acolher, quando deveria ter dado respostas às comunidades. O mecanismo, segundo a entrevista, tal como adotado, praticamente, é como se não tivesse havido a consideração pelo que as comunidades pleitearam. 
A consulta apresentaria um impacto positivo, ainda que com a limitação de que a composição administrativa não é providência de cunho negocial ou disponível, eis que é dever do Estado a máxima efetivação dos direitos dessas comunidades, conformando a interpretação normativa para atender os ditames da Constituição, sem escolhas. A previsão de solução das controvérsias jurídicas pela AGU, segundo o Ministério Público, como resultado da norma publicada (nova Instrução Normativa do Incra) teria sido um equívoco porque não se podem ceder direitos em apreço.

Sobre especificamente a Instrução Normativa editada, teria havido excesso de burocracia, inviabilizadora da regularização fundiária de comunidades quilombolas, ao se prever a oitiva de muitos órgãos, tornando o procedimento custoso, lento, burocrático e difícil. Os antropólogos do governo também teriam reclamado da burocratização do Relatório Técnico de Identificação e Delimitação (RTID), trabalho técnico que embasa a regularização fundiária elevada a efeito pelo Incra, na opinião do integrante do Ministério Público entrevistado.

A Corte Interamericana de Direitos Humanos teria expedido documento criticando a consulta pública realizada diante da constatação de que não teriam sido atendidos os seus parâmetros mínimos e porque teria gerado um processo de regularização socialmente oneroso e carente de vontade política.

\section{As Possibilidades de Contribuição da Advocacia de Estado: Resultados Percebidos como Favoráveis à Gestão de Políticas Públicas}

Para alguns entrevistados, os resultados do grupo de trabalho, assim como diversas outras medidas gerenciais da AGU, teriam comprovado o privilégio da construção da cultura da conciliação, que implica a administração ser parte não apenas do problema, mas de sua solução e que a AGU teria de fato tomado uma posição, uma decisão neste sentido, de ser parte da solução do problema.

Em determinados assuntos, a disputa da Seppir, FCP, MDA e Incra com o MMA era aplacada, para a defesa de interesses comuns, quando se fazia uma composição de forças, a depender do assunto, e as atividades do grupo ajudaram a institucionalizar isto, ou seja, a possibilidade de articulação administrativa. 
Com as atividades do grupo de trabalho, a AGU teria possibilitado que se fizesse a primeira consulta pública a comunidades tradicionais para fins de alteração de um ato normativo, conforme previsto no artigo $6^{\circ}$, item 1, letra "a", da Convenção OIT n ${ }^{\circ} 169$, incorporada ao ordenamento jurídico brasileiro pelo Decreto ${ }^{\circ} 5.051$ (BRASIL, 2004). Que esse papel da AGU, segundo alguns entrevistados, como mediadora e organizadora da consulta pública, foi essencial e histórico. Esta forma de atuação está contemplada na doutrina de BOBBIO (1984), em que se investiga a análise e utilização da estrutura burocrática para a composição democrática.

Em grande medida, havia um ambiente no governo favorável à determinação de se buscar uma resolução consensuada, embora a litigância intragovernamental estivesse definida e identificados os polos em atrito.

A nova Instrução Normativa do Incra, regulamentando o procedimento para identificação, reconhecimento, delimitação, demarcação, desintrusão, titulação e registro das terras ocupadas por remanescentes das comunidades dos quilombos, além de diferenciar a titulação de terras ocupadas por remanescentes de quilombos do direito das terras tradicionalmente ocupadas por indígenas, estabeleceu mecanismos de solução de conflitos em relação a particulares, e quanto a outros órgãos e entidades públicas.

O grupo de trabalho, ao fazer tecer uma minuta de instrução normativa acerca dos procedimentos de titulação de terras ocupadas por remanescentes de quilombos, buscou contemplar, para alguns entrevistados, todas as dificuldades e conflitos então existentes, porque esteve na metodologia do grupo de trabalho a ampla identificação dos problemas, e não apenas a solução da litigância intragovernamental central.

Foi destaque que o procedimento tenha sido democrático, com a participação de todos os interessados e com a harmonização, na medida do possível, de todos os aspectos jurídicos em conflitos.

Houve a menção, pela metade dos entrevistados, de que os trabalhos desenvolvidos significaram momento histórico, em que se reconheceu a importância de todos os órgãos envolvidos, cada contribuindo com a sua área de atuação, e a necessidade de se compatibilizar direitos igualmente reconhecidos como relevante pela Constituição Federal.

Destacou-se, ainda, que, no momento da consulta pública, mesmo quando se entendia que alguma demanda ou posicionamento dos representantes das comunidades remanescentes 
de quilombos não podia ser atendido, se expunham as razões do seu não acolhimento, aproveitando a oportunidade da consulta pública para o exercício da verdadeira dialética democrática. Devido a esse esforço, teria sido possível a compreensão dos encaminhamentos mesmo que mediante o não atendimento das demandas dos representantes sociais. Sob esta ótica entrevistada, a administração, no procedimento de consulta, não teria se colocado em posição hegemônica, mas de prestígio ao instituto da consulta, previsto em norma de abrangência internacional.

Neste ponto é relevante recordar a concepção de O'DONNELL (2011) e DAHL (1976), quanto à capacidade da agencia de participar e de interferir, elementos que consubstanciam a configuração do processo democrático.

A consulta teria implicado conduta administrativa inédita, firme, organizada e corajosa, segundo um entrevistado, marcando "a AGU como o espaço institucional apto na Administração Pública para a gestão e solução de conflitos.

Observou-se ainda, para um entrevistado, que os trabalhos em exame serviram para "fortalecer o entendimento acerca da constitucionalidade do Decreto ${ }^{\circ} 4.887$ (BRASIL, 2003) e para o reconhecimento quanto à aplicação da Convenção OIT nº 169 às comunidades quilombolas, mediante um espaço franco de diálogo interinstitucional, no qual os conflitos tornaram-se visíveis e as possíveis soluções foram partilhadas”.

Consequentemente, ficou indicado ser necessário que os representantes das organizações envolvidas devam deter prévio conhecimento quanto ao tema a ser discutido nos procedimentos de solução da litigância intragovernamental, a fim de que estejam empoderados para a representação a ser exercida. Também teria sido indicado que as sucessivas mudanças de titulares dos órgãos e entidades públicas são elementos dificultadores dos trabalhos de conciliação, à medida em que se interfere na memória administrativa.

A “consulta pública realizada foi pioneira não apenas em razão de seu ineditismo, mas também ao reconhecer de maneira expressa a aplicação da Convenção OIT no 169 às comunidades quilombolas", de acordo com um entrevistado, uma vez que em momento pretérito esta prerrogativa se lhes havia sido negada. A consulta teria sido um espaço de reconhecimento do outro, de respeito aos interesses daqueles a quem as políticas públicas em questão estão direcionadas. 
Outro aspecto importante das atividades do grupo de trabalho teria sido a construção de uma metodologia de consulta, o que gerou a sua reprodução em subsequentes iniciativas no âmbito do MDA. Embora não tenha havido nenhum outro procedimento de mesma envergadura, a construção dialógica foi relevante inclusive para o prosseguimento das políticas públicas, porque as comunidades adquiriram "considerável confiança na atuação com a Administração", mediante a construção de um ambiente favorável à boa-fé e ao diálogo. O "processo de consulta aliviou as tensões" e teria dado margem para a credibilidade na atuação, por exemplo, por parte do MDA. Este fenômeno teria sido útil para suplantar as críticas iniciais que as comunidades quilombolas faziam, no sentido de que "o Incra estava terceirizando a sua competência para a AGU”, relata um entrevistado.

O ganho de credibilidade possibilitou espaço para institucionalizar no Incra a Coordenação de Regularização Fundiária de Comunidades Tradicionais, medida favorável para as comunidades quilombolas aceitarem a atuação institucional da autarquia, que sucedeu a FCP nessa competência.

Nada obstante a consulta pública com aquele formato atribuído pelo grupo de trabalho não mais tenha se reproduzido, teria sido "marco muito importante porque as comunidades e o MPF participaram da construção da sua metodologia, atribuindo-lhe ainda mais legitimidade".

A consulta foi uma inovação e a sua realização firmou um paradigma, para outro entrevistado. Até aquele momento na OIT ainda não se teria chegado a uma conclusão clara quanto à natureza da consulta prevista em sua Convenção, se teria natureza deliberativa ou apenas de ausculta.

Houve uma tentativa de implementar a consulta pública quanto à controvérsia no município de Alcântara, no estado do Maranhão, onde a litigância se configuraria na disputa entre comunidades quilombolas, o setor ambiental e a área militar e de defesa e segurança nacional, diante da construção de uma estação aeroespacial, mas o procedimento não teria logrado em nada ser semelhante ao que ficou consignado no grupo de trabalho em estudo, porque falhara a tentativa de consulta.

As atividades empreendidas pela AGU teriam aberto oportunidade de diálogo e posto luz na discussão das políticas públicas em relevo, com peso na implementação de direito constitucionalmente previsto, além de implicar que o assunto quilombola fosse acolhido na 
pauta da Administração e que a consulta, fundada na convenção internacional, pudesse ser internalizada no serviço público nacional.

Consignou-se mesmo um reforço que a consulta foi histórica e que firmou uma metodologia que fez relevo administrativo. $\mathrm{O}$ fato de que o modelo não tenha sido repetido, segundo um entrevistado, não o decresce, ao contrário, enseja a sua reprodução.

Antes da realização da consulta pela $\mathrm{AGU}$, o assunto foi objeto de uma prévia avaliação por parte dos integrantes da Sexta Câmara do Ministério Público Federal ${ }^{30}$, com a competência para a defesa de grupos que têm em comum um modo de vida tradicional distinto da sociedade nacional majoritária, como indígenas, quilombolas, comunidades extrativistas e comunidades ribeirinhas e ciganos. Como relatou o integrante do Ministério Público, fora deliberado, por maioria, quanto à possibilidade de realização da consulta pública como proposta da AGU. Diante disto, houve um estímulo a que as comunidades acatassem o procedimento oferecido pela AGU de realizar a consulta quanto à alteração da IN do Incra.

Identificaram-se, ainda, os seguintes aspectos de relevo para a memória institucional administrativa: a formalidade do procedimento, documentado integralmente em processo administrativo autuado, mediante registro e compartilhamento da documentação gerada, o que implica reverter o óbice burocrático em favor da consecução democrática (BOBBIO, 1984); a construção laboriosa e paciente do consenso, a partir do absoluto dissenso inaugural, mediante procedimento dialógico e respeitoso (O'DONNELL, 2011); estabelecimento conjunto dos critérios preliminares, concomitantes e de encerramento das diversas fases do trabalho; planejamento, modelagem e formalização da primeira consulta pública de que se tem notícia, dando efetividade ao Decreto $n^{\circ} 5.051$ (BRASIL, 2004); a construção de trabalho conjunto e respeito a todas as participações, de maneira a que todos os encaminhamentos fossem discutidos e nenhum prevalecente por imposição ou por argumento de autoridade (conceito de poliarquia, de DAHL (1997)); os procedimentos burocráticos precisos garantiram a segurança e a credibilidade dos trabalhos.

Este ponto acerca do exato aproveitamento da estrutura burocrática em prol de resultado confiável é relevante porque o estudo da litigância intragovernamental não pode

\footnotetext{
${ }^{30}$ Disponível em: <http://www.mpf.mp.br/conheca-o-mpf/atuacao/camaras-de-coordenacao-e-revisao/6acamara>. Acesso em: 28/12/2016.
} 
se afastar de uma avaliação quanto à relevância da burocracia e do quanto sua aplicação equilibrada beneficia o atingimento dos fins estatais, enquanto o apego dos gestores ao conflito seria uma forma de tergiversá-la, em prol da manutenção de posições de baixa envergadura pública e à custa da ineficiência.

Com a consulta realizada, o Brasil teria cambiado a sua posição jurídica junto à OIT, pois, antes indagado a que comunidades entendia aplicável a Convenção promulgada, havia encaminhado a resposta de que apenas seriam suas destinatárias as comunidades indígenas. Desta forma, para um entrevistado que fez este relato, a consulta realizada ampliou as possibilidades do procedimento, afirmando as comunidades quilombolas como sujeitos dos direitos previstos na Convenção OIT.

Uma das respostas pontuou o entendimento de que os debates realizados no âmbito da consulta foram longos e produtivos, para aquele momento, e definiu o procedimento como a experiência mais ética que o governo já adotou, embora hoje os parâmetros da Corte Interamericana de Direitos Humanos sobre consulta pública tenham sido alargados.

O fato de que o governo tenha instituído um grupo de trabalho para disciplinar a Convenção OIT, ainda sem conclusão aponta para a prerrogativa histórica daquele momento, para um dos entrevistados, embora em seguida a IN tenha sido modificada sem que o Incra tenha adotado o mesmo procedimento de consulta existente para a elaboração do texto originário.

Tratando de consulta que prestigiou o atendimento de população classificada pelo Ministério Público como minoritária, permite-se a ilação de que o procedimento democrático é impactante para a inserção social e para o desenvolvimento, assim como, na lição de DAHL (1985), este elemento (desenvolvimento) é determinante, embora a ressalva do autor, de não expressamente definitivo, para a construção de uma sociedade plúrima e democrática.

\section{A contribuição para o Estado}

O grupo de trabalho coordenado pela AGU tinha como atribuição encaminhar identificar os problemas administrativos causais da litigância intragovernamental, analisálos e encaminhar a solução, para evitar que a políticas públicas, especialmente, como no caso concreto, de feição constitucional, não deixassem de ser efetivadas. 
Os relatos do estudo de caso, especialmente quanto à audiência pública realizada na Câmara dos Deputados, a ausências das comunidades quilombolas na primeira tentativa de realização da consulta pública e a maciça participação das comunidades na consulta pública efetivamente realizada, a existência de um projeto de decreto legislativo e de uma Ação direta de inconstitucionalidade são sintomas para a contextualização do nível de tensão social gerada, diante da demanda do corpo social, em face da sua regularização fundiária. O’DONNELL (2011, p. 137) pontua como, neste ambiente, a categoria Estado ganha relevo, podendo ser a causa ou a solução dos conflitos:

[...] um estado forte está entrelaçado densamente com a sociedade por meio da efetividade de sua legalidade e da eficácia de burocracias que operam regularmente para apoiar e executar essa legalidade. Este tipo de estado gera e garante o bem público de uma ordem social razoavelmente previsível, tanto por sua reprodução habitualmente pressuposta quanto pela expectativa de cumprimento dos direitos e obrigações que sanciona. Um estado assim tem um poder infraestrutural significativo, no sentido de que tende a ter elevado grau de satisfação em suas quatro dimensões; consequentemente suas políticas, bem como sua própria existência costumam ser normal e amplamente aceitas. É claro, esta é uma descrição típico-ideal, mas quanto mais se movimentam nessa direção os casos reais, tanto a sociedade quanto o estado se tornam mais fortes. Por outro lado, quando sistemas de poder privatizado governam realmente e/ou quando prevalece a incerteza generalizada sobre as relações sociais e políticas, tanto o estado - sem prejuízo do tamanho de seu aparato - quanto a sociedade se fragilizam.

[...] sempre que suas quatro dimensões funcionam razoavelmente bem, o estado proporciona bens públicos muito valiosos; além disso, se está atrelado a um regime democrático, o estado sanciona e apóia liberdades e direitos universalmente igualitários da cidadania social e cultural. Por outro lado, tanto por meio de seu sistema legal quanto pelas tentações autoritárias de suas burocracias (incluindo atualmente fortes componentes tecnocráticos) o estado condensa diversas relações sociais intrínsecas - e poderosamente - desiguais. Esta é uma antinomia básica, constitutiva da 
vida social. No nível da lei, ela se expressa por suas tensões inerentes entre diversos valores. Uma destas tensões, entre a estabilidade e a possibilidade de questionamentos da lei, já foi mencionada. Outra tensão por Aristóteles e implícita em minha discussão [...] dos processos de transformação legal é entre, por um lado, seus aspectos de igualdade formal e universalista e, por outro lado, de justiça substantiva e equidade. Estas antinomias só podem manifestar-se plenamente, e mobilizar-se politicamente, sob os direitos da democracia, mesmo que seja uma democracia limitada que só reconheça direitos políticos e poucos direitos civis, sociais e culturais. Essas antinomias podem ser lamentadas por uma mente linear ou fortemente conservadora, mas deveriam ser celebradas; na medida em que se expressam tensões que constituem inerentemente tanto a sociedade quanto o estado, podem ser mobilizadas por Ações individuais e coletivas que promovem um horizonte sempre aberto de esperanças e possibilidades na dinâmica social.

Temos ainda de considerar que [...] o estado é uma experiência vívida; suas muitas faces são um componente fundamental da realidade social e do próprio estado.

Para o enfrentamento dos desafios gerenciais, a administração se depara com o dilema de manter a forma já estabelecida em sua tradição burocrática, de gerenciamento dos processos de maneira meramente formal, ou aliar a isto novas formas de leitura, abordagem e deliberação. Nem sempre o novo caminho sinaliza o procedimento mais rápido a ser atingido, mas, muitas vezes, a falta de solução permanente em cotejo com uma solução mais delongada justifica o trabalho mais árduo, porém mais efetivo.

Por exemplo, o esforço pela condução democrática gera a necessidade de empenho e resiliência. Alguns ensinamentos indicam o efeito considerável da amplitude de visão e a postura participativa. A seguir, na expressão de DAHL; LINDBLOM (1953, p. 35) e de outros autores, alguns pontos podem ser percebidos quando o foco teleológico está delineado:

Seria difícil sugerir um conjunto de fins que não requeira um enorme volume de cooperação e interação humanas. Odeie ou ame o homem outras 
pessoas, deseje ampliar-lhes a liberdade ou escravizá-las, queira hierarquia ou igualdade, jogos de futebol ou campo de concentração, ele não terá sucesso em seus objetivos sem a cooperação (ou interação) de outras pessoas. O democrata, o tirano, o conspirador, o criminoso, o liberal, o socialista, o comunista, o chefe político, o empresário, o líder de clube, o professor, o Politiburo ${ }^{31}$, o Presidente dos Estados Unidos, o Papa - todos sem exceção, precisam da cooperação de numerosas outras pessoas para realizar seus fins. A necessidade de cooperação de numerosas outras pessoas para realizar seus fins. A necessidade de cooperação para realizálos constitui um fator básico da existência humana.

Muitos fins são impossíveis a menos que a cooperação (ou interação) seja relativamente estável, persistente e repetitiva. Nos casos em que a cooperação (interação) entre os seres humanos é relativamente estável, persistente e repetitiva, esta rede de relações interpessoais denomina-se de organização social [...]. Dizer que numerosos fins exigem cooperação ou interação estável, persistente e repetitiva entre seres humanos, por conseguinte, equivale a dizer que alguns fins requerem organizações social (sic), ou também que a liberdade exige organização social.

Nem sempre há conflito entre liberdade individual e doutrinação social. Nenhuma pessoa inteligente pode por seriamente em dúvida a necessidade de habituação ou treinamento social de realizações 'físicas'. É perfeitamente claro que cooperação estável, persistente e repetitiva entre indivíduos requer hábitos. Não obstante, a mesma pessoa que aceita a necessidade de habituação, amiúde, rejeita a necessidade de doutrinação social ou treinamento de reações do reino das atividades, ideias, crenças, normas, códigos ou sistemas éticos.

PUTNAM (1993, p. 180), responsável por pesquisa em diversas regiões italianas, ao longo de cerca de vinte anos, investigou "padrões e sistemas dinâmicos de engajamento

${ }^{31}$ Politburo, in Russian and Soviet history, the supreme policy-making body of the Communist Party of the Soviet Union. The Politburo until July 1990 exercised supreme control over the Soviet government; in 1990 the Politburo was enlarged and was separated to a certain degree from control over the Soviet government. With the breakup of the Soviet Union in 1991 and the subsequent banning of the Communist Party in Russia (1991), the Politburo also was effectively dissolved. The first Politburo was created in Russia by the Bolshevik Party Central Committee in late October 1917. Disponível em: <https://global.britannica.com/topic/Politburo>. Acesso em: 29/12/2016. 
cívico", identificando uma "forte relação entre desempenho institucional e comunidade cívica". No sexto capítulo de sua obra, em que documenta os resultados de seu trabalho, logrou concluir o apreço pela confiança e pela cooperação no ambiente investigado:

A confiança promove a cooperação. Quanto mais elevado o nível de confiança numa comunidade, maior a probabilidade de haver cooperação. E a própria cooperação gera confiança. A progressiva acumulação de capital social é uma das principais responsáveis pelos círculos virtuosos na Itália cívica.

A confiança necessária para fomentar a cooperação não é uma confiança cega. A confiança implica uma previsão do comportamento de um ator independente: "Você não confia em que uma pessoa (ou uma entidade) fará alguma coisa simplesmente porque ela disse que irá fazer. Você só confia porque, conhecendo a disposição dela, as alternativas de que dispõe e suas conseqüências, a capacidade dela e tudo o mais, você espera que ela preferirá agir assim". Em comunidades pequena e coesas, tal previsão pode basear-se no que Bernard Williams denomina "confiança irrestrita", ou seja, a que resulta do convívio íntimo com aquela pessoa. Em contextos mais amplos e complexos, porém, é preciso haver uma forma de confiança mais impessoal ou indireta. Como será que a confiança pessoal se transforma em confiança social?

O comentário sobre a confiança como decorrência do grupo de trabalho avaliado nesta pesquisa também se fez presente na entrevista da então Assessora Especial do Ministro do Desenvolvimento Agrário. De um ambiente de admitida desconfiança institucional e de incômodo, diante da atuação da AGU no caso, passou-se a uma situação em que a confiança no trabalho desta rendeu, na avaliação da entrevistada, consequências permanentes e favoráveis posteriores para o relacionamento do governo com as comunidades quilombolas.

Outro ponto sublinhado nas entrevistas, constante na expressão dos então AdvogadoGeral e Consultor-Geral da União, teria sido a capacidade técnica revestida em dois fenômenos observados quando se comparam os desdobramentos logrados: o cuidado com a produção documental, a fim que todos os expedientes, todas as reuniões e as decisões fossem objeto de registro e de instrução do processo, especialmente as comunicações prévias sobre 
o texto da norma que seria objeto de consulta, fato de impacto na presunção de boa-fé da consulta; e a técnica de abordagem e tratamento das informações e dos argumentos trazidos ao debate, de maneira a que o resultado tenha se consubstanciado na deliberação pelo completo consenso.

Quanto à capacidade técnica para a conciliação realizada, convém observar, como registro histórico, que as atividades do grupo de trabalho constantes do estudo de caso, ocorriam concomitantemente aos trabalhos de institucionalização da Câmara de Conciliação e Arbitragem da Administração Federal (CCAF), departamento da Consultoria-Geral da União que passou a figurar na estrutura organizacional com a edição do Ato Regimental AGU n ${ }^{\circ} 5^{32}$, de 27 de setembro de 2007.

Embora já houvesse atividades de conciliação da AGU desde a edição da Medida Provisória $n^{\mathrm{o}} 2.180-35^{33}$, de 24 de agosto de 2001, a consolidação da atividade conciliatória ocorreu com a institucionalização declinada, inclusive com a definição dos seus procedimentos, objeto da Portaria AGU n ${ }^{\circ} 1.281^{34}$, de 27 de setembro de 2007, que revogou a Portaria $\mathrm{n}^{\circ} 118$, de $1^{\circ}$ de fevereiro de 2007 , esta que ainda tratava da conciliação ad hoc, por força da Medida Provisória. Tal cronologia consta no artigo "Políticas de acesso à justiça: mediação”, de LÚCIO; RODRIGUES (2016, p. 312, grifo do autor), onde se colhe:

\begin{abstract}
Não foi ao acaso a previsão de solução extrajudicial de conflitos administrativo se operar no âmbito da vertente consultiva da AGU, porque assim está configurada a possibilidade efetiva de prevenção da judicialização, sem o prejuízo de que a litigância governamental já ajuizada possa ser revertida. Implica dizer que todas as demandas entre órgãos (Administração Direta) ou entidades (Administração Indireta) federais, desde a edição da mencionada Medida Provisória, são passíveis de ser solucionadas pela AGU.
\end{abstract}

\footnotetext{
${ }^{32}$ Disponível em: <http://www.agu.gov.br/page/content/detail/id_conteudo/82296>. Acesso em: 30/12/2016.

${ }^{33}$ Disponível em: <https://www.planalto.gov.br/ccivil_03/mpv/2180-35.htm>. Acesso em: 30/12/2016.

${ }^{34}$ Disponível em: <http://www.agu.gov.br/atos/detalhe/24515>. Acesso em: 30/12/2016.
} 
Promoveu-se na AGU a eleição da terminologia para estabelecimento de conciliação e arbitragem na AGU: Câmara de Conciliação e Arbitragem da Administração Federal.

Por conciliação restou, convencionada na AGU, a possibilidade de a litigância intragovernamental, judicializada ou não, ser solucionada por procedimento de autocomposição administrativa. A arbitragem foi destinada às situações em que, tramitado o procedimento, estariam esgotadas as possibilidades de consenso, ocasionando a decisão por emissão de manifestação jurídica, via de regra, editada sob a forma de parecer, em que o resultado seria atribuído unilateralmente pelo membro da AGU responsável pelo processo.

O ambiente institucional naquele contexto era favorável à inauguração de procedimentos de conciliação e havia credibilidade institucional e o entendimento corrente já naquele momento de que a conciliação de interesses públicos não estava voltada a sua negociação, mas ao esforço pelo diálogo e pelo consenso, a fim de, exatamente, evitar que a litigância intragovernamental (âmbito da Administração Federal) não figurasse um óbice à implementação das políticas públicas; para que não obstaculizasse a gestão, impedindo, muito especialmente, a satisfação do direito fundamental à boa administração (FREITAS, 2007).

Nesse contexto, não se cogita de discricionariedade, efetivamente diante das seguintes constatações: (1) não existe a possibilidade de a litigância perdurar, porque está se discutindo direito indisponível que ultrapassa a seara do direito administrativo para intervir no cumprimento do comando constitucional; (2) medidas devem ser tomadas para a execução das políticas públicas, missão de gestores e seus advogados; (3) as regras existem e não há álea para voluntarismo; o poder na administração é dever para o gestor, dever de efetivar as políticas públicas.

Como se constatará adiante, no caso estudado, um fenômeno imperativo também se operou, tal como observado na pesquisa descrita por CZARNIAWSKA-JOERGES (1997): ingerência de autoridade que logra uma atuação forte e mediante conquista de respeito e credibilidade, o que ficou apontado na figura do então Consultor-Geral da União. 
O atendimento a requisitos formais para a instrução do processo, não é exclusivo, mas é a seara de atuação do jurista e sua contribuição para a administração está vocacionada a instrumentalização em forma e conteúdo dos procedimentos, um componente na estrutura burocrática.

Apesar da formação jurídica, curiosamente, WEBER (2015, p. 135) admitiu que os componentes da administração "odeiam" os advogados, que os classificam como intermediários "incômodos e querelantes".

Esse relacionamento ainda merece aprimoramento, porque a falta de compreensão recíproca das possibilidades de atuação conjunta e exitosa onera o Estado e impede o cumprimento de sua missão.

A mudança dos paradigmas jurídicos desafia os advogados a outra forma de abordagem na administração. WEBER (2015), o cientista consagrado pelo tratamento da burocracia, teve formação jurídica, mas os currículos jurídicos ainda precisam ser atualizados para a composição acadêmica sobre gestão (burocracia) e resolução pacífica de conflitos, com complemento que não servirá apenas ao ingresso da advocacia de Estado, mas na gestão de bancas privadas.

DAHL; LINDBLOM (1953, p. 229-230), não obstante critiquem a abordagem seminal de WEBER (2015) sobre burocracia, admitem que todos os demais que tentaram tratar sobre o tema "devem-lhe alguma coisa" e discorrem sobre o assunto:

A burocracia é a moderna organização onipresente dentro da qual mais comumente desenvolveram-se os processos hierárquicos; é também um dos mais usados e importantes processos sociais operantes das sociedades modernas. A maioria das vantagens e desvantagens da hierarquia pode ser descoberta mediante exame das organizações burocráticas.

Naturalmente, a palavra "burocracia" em si é ambígua. Por burocracia numerosas pessoas entendem uma organização assinalada por certas características geralmente consideradas indesejáveis, principalmente a tramitação difícil de papeis, a transferência de responsabilidades para outrem, inflexibilidade excessiva, impessoalidade, e excesso de centralização. Por outro lado, crescente número de sociólogos, cientistas políticos e especialistas em administração entendem por burocracia uma 
organização marcada por certos aspectos estruturais que não se pode facilmente chamar de desejáveis ou indesejáveis per si.

Em verdade, ambos os grupos parecem geralmente interessados no mesmo tipo de processo hierárquico. [...] as organizações possuidoras de características estruturais que as distinguem das "burocracias" para os sociólogos e cientistas políticos, tendem também produzir as características (tramitação difícil, transferência de responsabilidades, inflexibilidade, impessoalidade e excesso de concentração) que tantas pessoas combatem quando a ela se referem.

Iniciando com a ressalva à modernidade, porque a obra é de 1953, o que se observa nos comentários é que a realidade administrativa descrita não mudou substancialmente.

E talvez não seja mesmo o caso de suplantar no sentido de substituir, mas de, efetivamente, evoluir e, primordialmente, simplificar. A literatura sobre gestão aplicável à iniciativa privada e parte da adaptação desta à esfera pública sinaliza esta perspectiva de modernização, com modelos de gestão em controle horizontal entre outras inovações.

Processos administrativos estão sendo convertidos em eletrônicos, a forma de comunicação atualizada para o meio digital, mas a essência das organizações, aqui descrevendo fortemente as públicas, ainda ensejam uma codificação burocrática, com o crivo inteligente.

$\mathrm{O}$ atendimento a determinado e ponderado formalismo, os registros das atividades desenvolvidas, como se percebeu no caso sob estudo, colaboram para a formação da memória administrativa, previnem o retrabalho e possibilitam, por exemplo, que um assunto deste jaez agora possa ser convertido em pesquisa acadêmica, esta que tem a pretensão de firmar efeito colaborativo em devolutiva para a gestão pública.

Não é despiciendo anotar que o emprego da burocracia aqui mais focado no formalismo obtemperado, cuida de não incorrer nos equívocos, por exemplo, apontados por O’DONNELL (1967, p. 323), em que a narrativa se referia ao esforço despendido para manutenção de estrutura de interesse social específico, viesada e bem identificada, sem a relevância ampla e pública.

De todas as entrevistas realizadas, a única que ficou, além do registro escrito, gravada em áudio, por expressa deliberação da entrevistada, foi a realizada com a integrante do 
Ministério Público Federal. Sobre a consulta pública, comentou (intervalo entre os minutos 7 e 9):

[...] eu reconheço os bons propósitos do Ronaldo, eu acho que ele teve um papel fundamental nisso. O Ronaldo vinha do movimento negro, conhecia algumas demandas do movimento negro urbano, não conhecia esse contexto de consulta [...].

$[\ldots]$

foi a primeira iniciativa de fato de levar a cabo uma consulta com responsabilidade e norteada pela boa-fé, que é aquilo que a Convenção $169 \operatorname{diz}[\ldots]$

[...] eu considerei importante a participação deles, das comunidades quilombolas, nesse processo porque o governo brasileiro tinha sido questionado pela OIT sobre quem eram os sujeitos de direito da Convenção 169 da OIT, se lembra que fala povos indígenas e povos tribais e o Brasil respondeu que só tinha povos indígenas. Como o governo estava fazendo aquela consulta pública às comunidades quilombolas e apenas a elas, porque o Decreto e a Instrução Normativa só dizia respeito e elas e não aos povos indígenas, eu achei que era uma oportunidade importante de afirmar que as comunidades quilombolas era sujeitos de direito da Convenção 169, não obstante o processo apresentasse falhas.

Eu ainda hoje falo em público que foi, talvez, a experiência mais ética do governo nesse processo de consulta. Ela está longe de ser assim, de seguir os parâmetros que depois a Corte Interamericana de Direitos Humanos disse que ela deveria ser, ela tem que ser culturalmente situada, então aquilo deveria ter sido transposto para uma linguagem mais adequada, mas, de qualquer, maneira, eu sou testemunha de que, enfim, o debate foi longo, foi produtivo [...].

Embora, em dado momento, a entrevistada faça ressalvas a aspectos formais que entendeu como essenciais e não contemplados pelo governo no caso concreto, como quanto à necessidade de as comunidades consultadas terem o conhecimento prévio, para o efetivo desempenho da capacidade de se manifestar a respeito do objeto consultado, a expressão 
transcrita demonstra três aspectos relevantes para a confiança estabelecida pela entrevistada no procedimento: credibilidade do agente público responsável, configuração da responsabilidade com que se desenvolvia o trabalho e efetividade da boa-fé com que se desenvolveram os trabalhos.

NORTH $^{35}$ (1990, p. 12) complementa a imagem, dispondo sobre a cooperação e advertindo sobre outros requisitos para a configuração da confiança (tradução da autora): o procedimento é sedimentado, ou seja, se reproduz; as pessoas possuem informações sobre o desempenho das demais; quando o grupo é delimitado, reduzido. Da mesma forma, a ausência desses elementos, propiciaria, por efeito inverso, a ausência de confiança.

35 To apply this approach briefly and in an oversimplied fashion, wealthmaximizing individuals will usually find it worthwhile to cooperate with others players when the play is repeated, when they possess complete informations about the other players' past performances, and when there are small numbers of players. $[\ldots]$.

Cooperation is difficult to sustain when the game is not repeated (or there is an end game), when information on the other players is lacking, and when there are large numbers of players. 


\section{NOVA ABORDAGEM PARA A LITIGÂNCIA: SEU APROVEITAMENTO PARA APRIMORAR O ESTADO}

Se nos dizem, repetidamente, que somos todos iguais enquanto membros desta nação, como é possível, ou aceitável, que alguns sofram severas privações $e$ desigualdades?

O’DONNELL (2011, p. 106)

\section{A identificação da Litigância Intragovernamental como oportunidade}

A observação da litigância intragovernamental, que se detecta no cenário da administração pública, aponta para possibilidades de aprimoramento da gestão, à medida em que a divergência pode ser vencida e não contemplada como obstáculo. A perspectiva exige a abertura de novos paradigmas ou simplesmente para não se cogitar imediatamente da instituição destes.

Como estímulo à mudança da trajetória, convém trazer GALBRAITH (1996, p. 156), ao rememorar que o "conflito, como todos sabem, é uma infecção que pode se alastrar."

A oportunidade indicaria exatamente o desafio plasmado em cogitar o novo. Este pensamento crítico não exige tanto esforço de vislumbre, porque, como vem sendo pontuado, as disposições no ordenamento jurídico, escalonado na forma do positivismo jurídico, como aqui se adota, ou sob qualquer outra perspectiva que se busque, apontam que a indefinição na prestação dos serviços públicos, em forma de políticas públicas, é hipótese inviável ou não-assunto.

Tomando em apreço o alerta de BORDIEU (2015, p. 25), adiante, para não desequilibrar investigação científica e empirismo, há que se cogitar que a realidade administrativa anuncia que a opção pela inércia de fato não existe, porque até mesmo esta já implicaria uma decisão, negativa de prestação do serviço público:

Em resumo, a invenção nunca se reduz a uma simples leitura do real, por mais desconcertante que seja, já que pressupõe sempre uma ruptura com o mesmo e com as configurações que ele propõe à percepção. Por insistir 
demais no papel do acaso na descoberta científica, como faz Robert K. Merton na análise da serendipity, expomo-nos a despertar as representações mais ingênuas da invenção, resumidas no paradigma da maçã de Newton: a apreensão de um fato inesperado pressupõe, pelo menos, a decisão de prestar uma atenção metodológica ao inesperado e sua virtude heurística depende da pertinência e coerência do sistema de indagações que ele coloca em questão. Sabe-se que o ato da invenção que conduz à solução de um problema sensório-motor ou abstrato deve quebrar as relações mais aparentes, por serem as mais familiares, para fazer surgir o novo sistema de relações entre os elementos. Em sociologia como alhures, "uma pesquisa séria leva a reunir o que o vulgo separa ou a distinguir o que o vulgo confunde."

No conceito de serendipidade compreende-se exatamente estar disposto a se deparar com novos achados diante de uma determinada busca, é expandir a oportunidade de novos resultados que não são completamente indesejados, mas podem ser imprevisíveis e afins ou pelo menos interessantes para o que se perquire. A composição administrativa como fruto do empenho de não permitir a propagação indeterminada do conflito gerador da litigância intragovernamental tem o potencial de abrir novas frentes para a questão gerencial.

Cumulativamente a este processo, existe a outra possibilidade em observar as falhas e trilhar sobre seus resultados, aproveitando, recompondo e construindo, como LATOUR (2012, p. 143) desafia os "estudiosos da ANT"36", a fim de encaminhar algo a edificação de um novo padrão. Agregando a isto, na lição de LÚCIO et al. (2014), seria viabilizar um novo instrumento, tendo-se em conta a definição e a distinção necessária entre instrumento, técnica e ferramenta: "o instrumento é um tipo de instituição social, a técnica é um dispositivo concreto de operacionalização do instrumento e a ferramenta é um microdispositivo no interior de uma técnica."

Conciliar os interesses é, como menciona LATOUR (1994 e 2012), ser, simultaneamente, "parte do problema e da sua solução, é conseguir ver por cima e por dentro".

\footnotetext{
${ }^{36}$ Em inglês Actor-Network-Theory (ANT), Teoria do Ator Rede, acrônimo que significa formiga, em inglês, espécie que com o autor se compararia, por ser míope, viciado em trabalho e farejador de trilhas, segundo explicam, na apresentação da obra os tradutores de Reagregando o Social.
} 
Na obra "O Futuro da Democracia (uma defesa das regras do jogo)", BOBBIO (1984) pondera acerca da prevalência sobre o governo de leis ou o governo de homens e sugere, arrimado em WEBER (2015), que não é indispensável decidir por um ângulo ou pelo outro, mas sopesá-los, identificar os aspectos geradores da litigância para construir um modelo novo ${ }^{37}$. Assim, os mesmos atores podem estar em posições diferentes e trazer apreciações que auxiliam na composição, percebendo-se que a abrangência democrática pode não estar apenas no ponto de partida, mas na possibilidade de prosseguir a participação com o fornecimento dos meios que encaminhem as deliberações, como no exemplo da consulta pública.

Com efeito, a escolha dos poderes executivo e legislativo mediante processo eleitoral é parte significativa do processo democrático, mas não o consubstancia em integralidade. Aliado a isto, o procedimento para pautar a agenda pública, mediante o detalhamento dos programas e políticas públicas implica conciliar uma perspectiva majoritária com as diversas nuances da implementação. É neste mister, como se vem discorrendo, que a litigância intragovernamental emerge para ser dirimida, mediante um procedimento conciliatório.

Esta leitura na administração, lidando com interesses indisponíveis, precisa ser esclarecida, se associa a uma espécie de composição que não gera renúncia, mas construção conjunta a fim de que prevaleçam os fins colimados, mediante a preservação do núcleo essencial do direito, exegese já sedimentada na jurisprudência do STF, como o procedimento razoável a ser adotado.

O’DONNELL (2011, p. 116), pautando o seu entendimento em Aristóteles, ratifica que o governo não é neutro ${ }^{38}$, deve ser guiado pela lei, concepção como produto dialógico, democrático, com a força necessária para impregnar a vontade de Estado:

\footnotetext{
${ }^{37}$ Segundo LÚCIO et al. (2015) trata-se de construir novas tecnologias, "a partir das redes de atores envolvidos, ou seja, das relações que estes estabelecem na constituição das redes e das tecnologias. Portanto, política e tecnologia não constituem uma dicotomia ou domínios separados, as escolhas tecnológicas também são escolhas políticas" (Callon; Lascoumes; Barthe, 2001).

${ }^{38}$ Conforme O’DONNELL (2001, p. 112/113):

(...) não existem um estado como algo neutro, orientado de uma maneira puramente técnica. Os estados condensam, processam e geram relações de poder que existem tanto na sociedade (a doméstica e transnacionalizada) quanto em suas instituições. (...) proponho um novo direito, um direito que, segundo meus conhecimentos, não foi ainda reconhecido pela teoria política ou legal. Nós, como cidadãos e /ou membros da nação/povo, temos um direito público e um estado que, obtendo notas razoavelmente satisfatórias em suas quatro dimensões $(*)$, converta-se em um coconstrutor e promotor de versões razoáveis do bem comum, assim como dos vários aspectos da cidadania resultante da democracia. Este tipo de estado é âncora e promotor da cidadania. É oi único lugar institucional em que os direitos podem ser inscritos (em
} 
A lei é uma dimensão fundamental do estado, proporciona a estrutura subjacente que sustenta as relações de uma sociedade.

$[\ldots]$

A ideia básica vem da Grécia clássica, especialmente de Aristóteles, que defendeu a conhecida fórmula de que as entidades políticas devem ser governadas por leis, não por homens.

Com a prevalência de uma outra concepção, é relevante que o Estado seja um espaço em que se viabilize a construção conjunta dos instrumentos e das tecnologias, o que pode trazer diversidade, ampliando ainda mais esta concepção democrática, como no dizer de LATOUR (2012, p. 23), ao referir que:

[...] "precisamos reformular nossas concepções daquilo que estava associado, pois a definição anterior se tornou praticamente irrelevante. Já não sabemos muito bem o que o termo "nós" significa; é como se estivéssemos atados por "laços" que não lembram em nada os vínculos sociais."

Sob outro enfoque, mas ainda abordando o foco da apreciação de BOBBIO (1984), O’DONNELL (2011, p. 132-133) acrescenta que não se há de falar em império da lei, simplesmente, mas de como se gere o Estado, composto de agentes públicos que devem se desicumbir, exitosamente, do seus munus:

O fato é que não existe literalmente algo como 'o império das leis'. O que existe na realidade são decisões tomadas por funcionários legalmente autorizados que se deparam com situações muitas vezes suscetíveis de diferentes interpretações legais e/ou fáticas, ou juízes que não desejam

seu sistema legal) e implementados (por burocracias relevantes). Os direitos não existem no ar ou apenas em discursos; existem, podem ser exigidos, e não podem ser facilmente revertidos, quando se convertem em parte efetiva e amplamente reconhecida da legalidade do estado, e quando suas burocracias orientam seu desempenho apoiando sua existência."

(*) São as quatro dimensões referidas: (1 conjunto de burocracias; (2) sistema legal; (3) foco da identidade coletiva; e (4) filtro para o bem-estar. Uma quinta dimensão poderia ser considerada para (5) estado como figura internacional. 
aplicar de maneira consistente ou equitativa a lei existente, e/ou são socialmente parciais, e/ou têm concepções legais que estão distantes dos princípios ou valores democráticos básicos. Por isso as lutas políticas são travadas frequentemente no terreno do que deveria ser a lei que vai ser escrita, ou do que deveria ser a interpretação de uma lei já dada. A lei, exatamente como o resto do estado de que é parte, está impregnada de relações de poder, e de interesses, valores e ideologias que são o prisma por meio do qual ela é escrita e aplicada. Existem variações significativas entre os países sobre o grau de como a lei é aplicada de modo que concorde com a democracia e a agência. [...] em alguns países, por meio da implantação extensiva de direitos civis, assim como de diferentes mas eficazes conjuntos de direitos sociais (também alguns culturais), o nível democrático da lei, e com esta do estado como um todo, registrou avanços importantes; isto proporcionou a muitos, embora não a todos, um mínimo de poderes legalmente sustentados que possibilitam a agência.

Por outro lado, uma vez sancionadas, quando as relações de poder originais já desapareceram, as regras legais assim como as instituições estatais têm seus próprios efeitos contínuos: por meio da extensão ou restrição do alcance que se propôs a princípio, ela originam relações sociais imprevistas por aqueles que legislaram inicialmente. Estes 'resíduos institucionais' são também campo de lutas políticas na medida em que se reconfiguram as relações sociais e intraestatais de forma que as questões estáticas ou formalistas da lei são incapazes de captar.

No estudo de caso trazido à lume, a necessidade de encaminhamento para a litigância demonstrou a necessidade de estabelecimento do mecanismo de consulta pública, que ainda não havia sido inaugurado.

Não havia procedimento estabelecido, mas a necessidade gerou a sua construção. Apenas anos depois deflagrou-se iniciativa para regulamentar o Decreto homologatório da Convenção internacional. Deixar de conciliar a litigância porque não havia regulamento ou deixar de fazer a consulta porque não estava disciplinada por certo atingiria o cerne da solução entabulada, que não seria aceita ou aviada sem o atendimento da consulta. 
Com o já apontado, não é a gestão normativa que se busca, mas a gestão em que normas podem ser instrumento, mas não os únicos.

Refiro aqui a expressão de saudosa mestra, de quem, na graduação, tive ensinamentos de introdução ao estudo do direito e de filosofia do direito, Prof. Manuela Pires Lourenço Torquato: muitas leis, pouca justiça!

Finalmente, a consulta implementada, em que pesem as críticas mais fortes, foi avaliada como interessante marco administrativo e social. Como ressalvado na referência de CZARNIAWSKA-JOERGES (1997), a avaliação do estudo de caso aprecia o seu contexto no momento, ainda que depois pode ser sido modificado, ampliado ou restringido.

\section{Prevenir ou utilizar o conflito como instrumento de aprimoramento da gestão?}

Ainda é CZARNIAWSKA-JOERGES (1997, p. 55) que observa que os homens estão sempre estruturando seus mundos e não estão sozinhos nesse desafio. Ao consubstanciar a possibilidade de conciliar a respeito dos atos administrativos que provocam a litigância intragovernamental e cuja configuração é previsível, passa a ser relevante, na perspectiva gerencial, observar, predizer e encaminhar.

À administração cabe o desafio, descrito por RUIZ ${ }^{39}$ (2014), reforçado em O’DONNELL (2011) ou em SARLET (2015), de o Estado se aprimorar para superar os seus próprios problemas, os entraves para a implementação das políticas públicas. Como é pensamento corrente na área de gestão, deve-se procurar mudar o proceder quando se almeja resultado melhor. Prosseguir na mesma conduta não deve ensejar a expectativa de resultados novos ou auspiciosos.

Com LÚCIO e COELHO (2010, p. 13) ficara vaticinado que:

[...] a mediação como instrumento de gestão contribui para ações de unificação do Estado brasileiro fortalecendo o paradigma da pacificação ao fixar este como uma missão comum a todos os órgãos, independentemente do lugar que ocupam na estrutura administrativa. Esse paradigma tende a

\footnotetext{
${ }^{39}$ Ibid
} 
fortalecer o atendimento ao cidadão, finalidade última do Estado brasileiro, como a ação prioritária dos órgãos públicos.

Ainda, com LÚCIO; RODRIGUES (2016, p. 321) estão colecionadas as iniciativas já adotadas, com um relato histórico, que indica a irreversibilidade do procedimento autocompositivo, anunciado que a nova legislação assegura a perenização da memória institucional que a AGU logrou disseminar.

Não implica o exposto que o trabalho se consolida com estas iniciativas; ao contrário, a estrutura administrativa da AGU não abarca a solução individualizada dos problemas, a Lei $n^{\circ}$ 13.140, (BRASIL, 2015) prevê expressamente que, a partir da experiência acumulada na AGU, a administração federal deve estar habilitada para o procedimento de solução da litigância intragovernamental, via autocomposição, mecanismo que também pode ser ampliado para as demandas externas à administração federal, seja em face de estados, municípios ou de particulares. Como ensina O'DONNELL, quando se detecta a situação em que é necessário agir, o caminho é um só: (2011, p. 115), "se necessário, uma autoridade fará com que a norma legal em questão seja cumprida."

A proposta contempla que a cultura autocompositiva se expanda na administração federal sob a capacitação técnica da AGU, consoante previsão legal em relevo, a fim de que haja efetivamente uma gestão da política pública de acesso à justiça, em amplo sentido, assim compreendida a possibilidade de resolução da litigância intragovernamental.

Sem exclusividade, mas fazendo valer seu protagonismo, já consolidado em texto legal e também sede acadêmica ${ }^{40}$, a AGU tem os meios potenciais para, em amparo à gestão finalística de cada seara administrativa, emprestar sua expertise para empoderamento dos gestores, na composição, mediante assessoramento com instrumentos, técnicas e ferramentas (LÚCIO et al., 2014), aprimorando e imprimindo salto qualitativo na gestão pública.

\section{Gerenciamento e Impacto de uma Nova Abordagem da Litigância}

Há algum tempo a visão de GALBRAITH (1996, p. 125, grifo nosso) se voltava ao papel do Estado na constituição de uma sociedade justa. Na obra com este título o autor

${ }^{40}$ Vide COELHO, 2012. 
explora com simplicidade e muito diretamente os aspectos em que se deve ater a boa administração, para o implemento desse ideário humano e universal:

O caso do órgão público é mais difícil. Aqui nem o compromisso institucional com a política estabelecida, nem a proliferação de pessoal possui os remédios embutidos existentes na organização privada. Pelo contrário, depende-se de uma gerencia eficaz e informada e de uma propensão em efetuar mudanças quando necessárias. Normalmente, qualquer ataque aos burocratas e à burocracia no setor público encobre a oposição ao serviço específico prestado, à lei específica cujo cumprimento está sendo exigido ou ao custo disso. Mas os problemas inerentes à síndrome burocrática existem no órgão público, assim como em qualquer grande organização. Sua solução está nas mãos de uma liderança vigilante nos poderes executivo e legislativo, e a solução é essencial para o funcionamento eficaz da sociedade justa.

Centrando no escopo deste trabalho, é de se destacar que GALBRAITH (1996) consigna acima o alerta do dever que cumpre ao poder executivo, compromisso que perpassa por encontrar as soluções e aviar os meios de sua efetivação, sem demérito do processo cognitivo que a litigância intragovernamental disponibiliza.

É em decorrência da necessidade que o Estado deve avançar para o desenvolvimento - categoria prestigiada neste Programa de Pós-Graduação (PIKETTY, 2013 e 2014).

O'DONNELL (2011, p. 73 e 129), inclusive observa que um "sistema legal razoavelmente efetivo realiza a grande contribuição de amparar e estabilizar a ordem social”, executa as políticas públicas e consolida a democracia:

[...] em que medida (e em que períodos e áreas de política pública) os insumos originários do regime pesam sobre outras influências? Qual é, em cada caso e em cada momento, a "seletividade estratégica" das instituições do estado em que áreas de política ela é mais pronunciada? Até que ponto a autoridade que se costuma invocar no sentido de representar as aspirações expressas por meio do regime democrático corresponde à realidade? Em que circunstâncias seriam admissíveis políticas públicas que se desviem 
dessas aspirações e/ou das promessas feitas durante o processo eleitoral? Estas perguntas não podem ser respondidas no nível de generalidade em que me encontro. Mas podemos conjeturar que só em casos negativos bastante extremos é Possível respondê-las com aproximação suficiente. Estes casos, infelizmente, não faltaram na experiência recente da democracia em boa parte da América Latina. Em muitos casos os insumos do regime foram débeis e descontínuos, atados a interesses às vezes difíceis de vincular com algum aspecto do bem comum. Estas circunstâncias não contribuíram para a eficácia, efetividade e credibilidade destes estados e de seus governos; além disso, estas circunstâncias ocasionalmente evidenciaram um estado que, em alguns países, renunciou quase por completo a operar como um filtro razoavelmente eficaz e benéfico.

As reflexões precedentes servem como um primeiro indício de uma importante preocupação deste livro: o escasso poder que na América Latina que os governos eleitos democraticamente e, em geral, os estados que contêm um regime democráticos, para governar efetivamente sobre questões importantes e, mais, para avançar na democratização e no bemestar de seus respectivos países.

Em outro apontamento O'DONNELL (2011, p. 136) elucida e reforça que o Estado deve estar preparado para sua missão, evitando incorrer no drama de Sísifo, o que se perfaz com a realização do necessário planejamento, voltando-se para efetivar o bem-estar social:

Nos tempos modernos, as lutas pela democracia e sua expansão foram em grande medida conflitos para que os direitos dos setores e das classes subordinadas fossem inscritos na lei e colocados em prática por burocracias estatais adequadas. A democracia e seus direitos fornecem o principal caminho pelo qual é possível obter alguns resultados de igualdade contra as tendências da desigualdade da burocracia e do capitalismo, bem como as discriminações de gênero, e outros cancros sociais. Os esforços igualadores são árduos e suas conquistas nunca estão garantidas em sua contínua efetividade. No entanto, isto não é tão desesperador quanto a história de Sísifo empurrando a rocha repetidamente da base da montanha; algumas áreas de igualação podem ser (e têm sido) conquistadas e 
expandidas, e até mesmo em períodos desfavoráveis podem ser defendidas, especialmente se são apoiadas pelos direitos da democracia política.

A propósito, isso nos ajuda a aproximar-nos de uma definição do estado forte. Se aceitarmos que é errôneo reduzir o estado a suas burocracias e portanto tender a ver suas relações com a sociedade como de soma zero, notamos que, para além do tamanho de suas burocracias, um estado forte está entrelaçado densamente com a sociedade por meio da efetividade de sua legalidade e da eficácia de burocracias que operam regularmente para apoiar e executar essa legalidade. Este tipo de estado gera e garante o bem público de uma ordem social razoavelmente previsível, tanto por sua reprodução habitualmente pressuposta quanto pela expectativa de cumprimento dos direitos e obrigações que sanciona. Um estado assim tem um poder infraestrutural significativo, no sentido de que tende a ter elevado grau de satisfação em suas quatro dimensões; consequentemente suas políticas, bem como sua própria existência costumam ser normal e amplamente aceitas. É claro, esta é uma descrição típico-ideal, mas quanto mais se movimentam nessa direção os casos reais, tanto a sociedade quanto o estado se tornam mais fortes. Por outro lado, quando sistemas de poder privatizado governam realmente e/ou quando prevalece a incerteza generalizada sobre as relações sociais e políticas, tanto o estado - sem prejuízo do tamanho de seu aparato - quanto a sociedade se fragiliza.

Para tanto, é auspicioso que possa se valer da produção interna - narrativa - e do aporte científico especializado, como instruído por CZARNIAWSKA-JOERGES (1997, p. 21), ou seja, "rotina e mudança, narrativa e ciência".

Assim como GALBRAITH (1996), partindo de uma comparação com o modelo gerencial privado, CZARNIAWSKA-JOERGES (1997) faz um apontamento de que é raro, num empreendimento privado, que um colaborador anuncie em público "nós não vamos administrar isto" 41 , pois é senso comum que o problema seja encaminhado, mesmo que o empreendimento esteja em situação ruim, mas que, infelizmente, esta realidade nem sempre é real no serviço público.

${ }^{41}$ Conforme CZARNIAWSKA-JOERGES (1997, p. 114): “We're not going do manage this." 
Naturalmente é de apontar, sobre a comparação com a iniciativa privada, que nem tudo se circunscreve à adaptação de instrumentos externos à Administração, mas pela concretude de planejamento sociotécnico (LÚCIO et al. (2014)), em que se contemple que os fins do Estado são bem diversos no contexto negocial, eis que neste o resultado ou a entrega é a execução de políticas públicas.

Em geral, a vontade do gestor fica delimitada à observância da concepção que abarca o ordenamento jurídico. Porém, além da Constituição Federal e do escalonamento hierárquico a partir desta, como discorrido pelo positivismo jurídico de KELSEN (1934), esta acepção deve estar cotejada com o entendimento de O’DONNELL (2011, p. 116/117), para quem o dever de fazer valer a norma não pode gerar o impedimentos mesmo de lhe dar efetividade. Atender a Constituição é buscar a efetividade da gestão que regulamenta e não encontrar justificativas para deixar de prestar o serviço do Estado:

A ideia de que o governo deve ser sub lege, sujeito a regras legais previamente promulgadas, mais tarde encontrou expressão formalmente elaborada no Rechssttaat prussiano. Esta concepção não é necessariamente democrática; é possível aplicá-la, como ocorreu na Prússia, em regimes autoritários institucionalizados e/ou naqueles que, como no antigo regime britânico, excluem ou restringem severamente a cidadania política; veremos que na democracia o estado de direito tem características adicionais.

[...] o sistema legal é um ordenamento hierárquico que tenta, embora nunca consiga totalmente, "fechar" por meio de sua plenitude ou compleição; decidir que as relações entre regras legais são determinadas legalmente supõe que os governantes devem se sujeitar a essas regras como todos os demais e não há momento no qual a vontade de um determinado ator, estatal ou privado, possa cancelar ou suspender de modo legítimo as regras que regem seu desempenho. Supõe-se, então, que ninguém, inclusive os mais altos funcionários do estado, é de legibus solutus.

Para o desenvolvimento do trabalho de reconstrução do modelo administrativo encetando a composição administrativa em apreço, o processo de tomada de decisão deve 
passar por novo direcionamento, que reverta padrões precedentes e se disponha ao desafio da inovação.

FREITAS (2015) denomina de processo de desenviesamento, atitude em que a forma de pensar, interpretar e deliberar deve passar por reavaliação do agente, no caso agente público, a fim de que se evite a mera reprodução dos meios de tomada de decisão antecedentes e que se abram possibilidades novas, observando, especialmente, os movimentos de interpretação a serem diferenciados. No parágrafo em que sucedem os modelos possíveis dos vieses, descreve:

Os desvios cognitivos estão presentes em toda atividade cerebral, sem que a interpretação jurídica represente exceção, por maior força que se queira destinar para os comandos externos que determinam a imparcialidade. É o que acontece com a heurística do afeto, consoante a qual as aversões e preferências, ao sabor de saltos infundados, culminam em julgamentos distorcidos. Daí segue a relevância de arrolar os principais vieses (biases) que comprometem a isenção e o balanceamento da interpretação jurídica, selecionados entre os mais frequentes.

A atitude do agente público frente à litigância intragovernamental deve conceber novo formato interpretativo, conciliação do que lhe é indisponível, dever de agir, performance de acordo com o ordenamento jurídico, porque é esta a conformação que a sociedade espera encontrar e na qual eventualmente pode ser chamada a participar.

Na compreensão de LE GALÉS; VEZINAT ${ }^{42}$ (2014, p. 16-17), a definição da autoridade política do Estado se exerce a partir de três elementos: a capacidade de tomar decisões que podem ser impostas à coletividade, de executá-las pelos meios apropriados e de lhes dar uma justificação normativa como poder de legitimação que conduz os sujeitos, à medida do possível, a sua observância. Tanto na França quanto em outros países europeus, na descrição de LE GALÉS; VEZINAT (2014), o desenvolvimento do Estado é associado a

\footnotetext{
${ }^{42}$ On peut definir l'autorité politique exercée par l'Etat à partir de trois elements: la capacité à pendre des décisions qui s'imposent à la collectivité, à lês mettre en œuvre par des moyens appropriés, à leur donner une justification normative (pouvoir de legitimation) qui amene autant que possible les sujets de l'autorité à s'y plier. Dans le cas français, comme dans le cas des autres pays européens, le renforcement de l'Etat est allé de pair avec une nationalisation de l'autorité politique, une quasi-monopolisation de cette autorité et l'institutionnalisation du príncipe démocratique et de la primauté du droit.
} 
uma nacionalização da autoridade política, um quase monopólio da institucionalização do princípio democrático e da primazia do direito. Embora mediante referência específica à situação europeia, expressa que as crises são sintomáticas de uma situação de tensão social e que há um desafio ao Estado administrá-las, interagindo com diversos atores e pondo em exercício as capacidades antes alinhadas. Na nossa realidade, perceber que a litigância intragovernamental é uma oportunidade a mais ao Estado de exercer seu papel e gerenciar as questões que a fomentam é aprender a compor a partir dos problemas que se detectam.

A ideia central é converter a dificuldade em instrumento de gestão que, sem ignorar, afastar ou negar as causas da litigância, investigue e aproveite a sua origem para viabilizar o encaminhamento. As tensões sociais não são os problemas, aprender a lidar com elas á a necessidade da democracia, cuja efetivação não se implementa com o preenchimento dos cargos. Na teoria de HAM e MICHAEL (1993, p. 228), é exercer o equilíbrio entre "frouxos apertados":

Finalmente, ao notar que a discricionariedade tem sido encarada como um problema, deveríamos reconhecer que uma variedade de estratégias de controle organizacional tem sido desenvolvida para se lidar com ele. A abordagem tradicional tem sido tentar controlar a discricionariedade mediante regras e procedimentos mais rígidos (conforme discutido no Capítulo 7). Mais recentemente, a identificação da natureza onipresente do fenômeno trouxe tentativas de estruturá-lo mediante controles de orçamento e sistemas, que têm sido descritos como "frouxo-apertados" (Elcock, 1991, p. 41), para implicar uma combinação de procedimentos rígidos com a delegação deliberada de áreas de discricionariedade.

Há que se identificar as margens de discricionariedade possível, numa reflexão compatibilizada com a compreensão de que não há a opção não resolver ou a alternativa prolongar a litigância. BAUMAN (1999) acentua que a liquidez favorecer a que se dê a flexibilidade da escolha e a possibilidade de que não seja um formato rígido, uma composição estreita, mas a resposta construtiva. Desprezar a contraposição é incrementar sua força, enquanto poderia ser bem usada para aprimorar a gestão, como recorda O’DONNELL (1988, p. 44): 
[...] o exercício democrático é laborioso, detalhado, persistente, porque "em nenhum caso conhecido parece ter havido uma maioria de democratas antes de ser implantada a democracia política (inclusive, como mostram alguns estudos sobre os Estados Unidos, nem sequer hoje, nesta democracia claramente consolidada, existe uma maioria de democratas no sentido acima definido)".

CZARNIAWSKA-JOERGES (1997) explora aspectos que podemos eleger como pontos significativos para lidar com a litigância intragovernamental: (1) viabilidade de contemplar as palavras como híbridos, como na descrição de LATOUR (2012); (2) os paradoxos são possibilidade de superação administrativa, mas, se não adequadamente tratados, não apenas paralisam a ação, mas a inabilitam e irritam, não porque vão de encontro à essência das coisas, mas porque arruínam a ordem convencional da superfície que é a nossa vida; (3) vislumbre de que há que se superar os obstáculos, e não as pessoas, pois com estas se objetiva o diálogo; (4) conhecer e laborar na perspectiva de que há a resistência para mudar; (5) existe a necessidade de enfrentar e superar o discurso meramente retórico e desgastado; (6) aproveitar a circunstância em que emerge a autoridade fashion, categoria simétrica à autoridade carismática (ABERS e KECK, 2013, p. 2), apontando que a conduta individual de alguns servidores do Estado influencia fortemente resultados; (7) observar o risco de ficar cego pelas próprias posições, fechando as possibilidade de inovar e integrar; (8) para o êxito na superação da litigância intragovernamental, é indispensável aguçado relacionamento dialógico; (9) pode se cogitar que se muda o contexto mudando comportamento; (10) projetar a possibilidade de que o mundo da prática seja capaz de conquistar o mundo da norma; (11) a gestão deve criar oportunidades aos que não são ouvidos; (12) vislumbrar a interpretação como objeto de pesquisa, de recontextualização e não como contraste para explanação; (12) dar espaço para o enfretamento entre práticos e teóricos; e (13) procurar manter o olhar interno, mas também propiciar o olhar por cima, em que se aproxima da concepção de LATOUR (2012).

O agir é premente, ainda se vislumbrado pela ótica do prestar contas, que é fundamental, não apenas nas instâncias públicas em sentido estrito, mas no seu mais amplo espectro, para com a sociedade, o que O’DONNELL (2011, p. 128) enfatiza, com a 
accountability horizontal e a social, exercida "por vários meios, que incluem meios legais, ONGs, movimentos sociais e diversas associações", que auxiliam na missão de fazer valer o esforço pelo republicano e o democrático.

CHOMSKY (1970, p. 71) recorda que o verdadeiro conteúdo dos direitos formais (revestidos em prestação pelo Estado), "é determinado pela disposição do povo de defendêlos".

BAUMAN (2010, p. 106) acrescenta a esta pesquisa, com ensinamentos sobre o desafio de que somente "juntos poderemos travar essa luta contra os 'males sociais' - ou a perderemos." $" 43$

${ }^{43}$ Vigésima primeira carta, denominada "Saúde de desigualdade". 


\section{CONSIDERAÇÕES FINAIS}

Dois desafios novos estão colocados aos advogados públicos: gestão e conciliação. É certo que parte desses conhecimentos não foram exigência em seu processo seletivo e, portanto, não compunham as bases de sua formação, mas são os requisitos para o desenvolvimento de uma performance atual, típicas dos que se destinam a servir ao público, seja na concepção de sociedade, seja na concepção do Estado.

No âmbito da gestão, juntamente com os administradores, tais desafios se materializam, ainda, com o controle externo, incluso nessa concepção o controle social, exercido em posição mais preponderante pelos meios de comunicação.

A expressão conciliação poderia até ser melhor contextualizada como conjugação, porque é ao que efetivamente se dispõe a administração, seja sob a égide do art. $3^{\text {o44 }}$ da Carta Política, seja para o atendimento das disposições da recente Lei $n^{\circ} 13.140$ (BRASIL, 2015) ou ainda alguns outros normativos de hierarquia normativa subjacente, que estabeleceram ao longo do tempo a necessidade de que os problemas internos da administração sejam encaminhados por gestores e seus assessores jurídicos ou sob as demais esferas técnicas.

Essa disposição sequer desprestigia e muito menos descumpre a previsão constitucional do acesso ao Judiciário, mas possibilita que a litigância intragovernamental seja dissipada na esfera apropriada para tanto, o setor interna corporis da administração, em qualquer dos Poderes da República.

Além de esta iniciativa viabilizar a desobstrução da estrutura administrativa da protelação de controvérsias que a oneram em termos burocráticos e financeiros ${ }^{45}$, viabilizando a implementação de políticas públicas obstadas, abre a possibilidade de oferta de outra política pública, por via transversa, mas não de menor importância, que é o acesso à justiça, em largo sentido, para provimento de efetivos interesses e necessidade social, do

\footnotetext{
${ }^{44}$ Art. $3^{\circ}$ Constituem objetivos fundamentais da República Federativa do Brasil:

I - construir uma sociedade livre, justa e solidária;

II - garantir o desenvolvimento nacional;

III - erradicar a pobreza e a marginalização e reduzir as desigualdades sociais e regionais;

IV - promover o bem de todos, sem preconceitos de origem, raça, sexo, cor, idade e quaisquer outras formas de discriminação.

Disponível em: <http://www.planalto.gov.br/ccivil_03/constituicao/constituicaocompilado.htm>. Acesso em: 30/12/2016).

${ }^{45} \mathrm{Na}$ acepção de financeiro compreende-se, neste contexto, a área administrativa compatível com o regimento orçamentário, égide de receitas e despesas públicas.
} 
cidadão, que perece mediante o insondável nível de demandas entre órgãos e entidades públicas que perfilam os escaninhos judiciais.

Nesse trilhar sequer consta, ainda, por necessidade de definição epistêmica, a abordagem das demandas do cidadão em face do poder público, também traçadas pela Lei n 13.140 (BRASIL, 2015) com o encaminhamento para a sua solução por mediação.

Estamos ainda buscando a melhor construção para que o Estado resolva, encaminhe e discipline os seus obstáculos internos para a satisfação da demanda do Estado democrático de direito, em que direitos e garantias possam ser ofertados ao cidadão, mediante uma atuação estatal eficiente e efetiva.

Não se trata de negociar com os direitos expostos no ordenamento jurídico, mas dirimir os obstáculos para a sua implementação, na conjugação das forças e dos interesses internos da administração, em prol dos interesses públicos. É trabalho para toda a administração, advogados e gestores.

Tampouco se trata de tomar a litigância como empecilho, mas como desafio a ser superado e extrair do seu âmago o aprimoramento da gestão, com a oferta do melhor suporte jurídico para a segurança do gestor que deve tomar a decisão.

Paralelamente, uma nova inteligência administrativa está disponível, mediante o planejamento sociotécnico, infundindo instrumentos de gestão dialógicos que viabilizem o encaminhamento conjugado da problemática burocrática, dando-lhe feição e dinamismos travestidos de inovação.

A litigância intragovernamental é um fato administrativo que pode ser laborado e convertido, de preliminar óbice à implementação de políticas públicas, diante das resistências que se manifestam de forma imbricada na estrutura administrativa, descuidando da satisfação das finalidades precípuas do Estado democrático de direito, para uma oportunidade de extensão do processo dialógico, mediante a conjugação de entendimentos, esforços e recursos para o atendimento do princípio da boa administração pública, que, em última instância, operacionaliza a dignidade e os direitos fundamentais da pessoa humana.

É um novo encaminhamento da discricionariedade, que não se reveste na opção de não atender ou de delonga no atendimento, mas na articulação necessária a que o processo de accountability não se conduza apenas e meramente ex post, eis que a sua legitimação e confiabilidade possam ser detectadas em concomitância. 
Há que se observar em que medida, efetivamente, os conflitos se geram da vontade do Estado e atendem aos preceitos democráticos ou são disputas por espaço de poder que maculam a satisfação do bem comum que os fins republicanos inscritos na Constituição Federal têm o escopo de resguardar mediante uma construção estatal complexas e autocooordenada. 


\section{BIBLIOGRAFIA}

ABERS, R. N.; KECK, M. E. Practical Authority: Agency and Institutional Change in Brazilian Ware politics. Oxford and New York: Oxford University Press, 2013.

BANDEIRA DE MELLO, Celso Antônio. Curso de Direito Administrativo. 40. ed. - São Paulo: Saraiva, 2016.

BAUMAN, Z. Para que serve a Sociologia? Diálogos com Michel Hviid Jacobsen e Keith Tester. Tradução Carlos Alberto Medeiros, 1. ed. - Rio de Janeiro: Zahar, 2014.

Zahar ed., 1999.

Em busca da política. Tradução Marcus Penchel. - Rio de Janeiro: Jorge

44 Cartas do mundo líquido moderno. Tradução Vera Pereira. - Rio de Janeiro: Zahar, 2010.

BAUER, M.W.; GASKELL G. Pesquisa Qualitativa com Texto, Imagem e Som: um Manual Prático. Tradução Pedrinho A. Guareschi. 13. ed. Petrópolis, - Rio de Janeiro: Vozes, 2015. 516 p.

BRASIL. Lei $\mathrm{n}^{\mathrm{o}}$ 13.140, de 26 de junho de 2015. Disponível em: <http://www.planalto.gov.br/ccivil_03/leis/LCP/Lcp73.htm>. Acesso em: 20 de dezembro de 2016.

. Lei $\mathrm{n}^{\mathrm{o}} 13.140$, de 26 de junho de 2015. Disponível em: <http://www.planalto.gov.br/ccivil_03/_Ato2015-2018/2015/Lei/L13140.htm>. Acesso em: 20 de dezembro de 2016.

Lei $\mathrm{n}^{\mathrm{o}}$ 3.071, de $1^{\mathrm{o}}$ de janeiro de 1906. Disponível em: $<$ https://www.planalto.gov.br/ccivil_03/Leis/L3071.htm>. Acesso em: 20 de dezembro de 2016.

<https://www.planalto.gov.br/ccivil_03/Leis/2002/L10406.htm\#art2045>. Acesso em: 20 de dezembro de 2016. 
Lei $\mathrm{n}^{\mathrm{o}}$ 13.341, de 29 de setembro de 2016. Disponível em: $<$ http://www.planalto.gov.br/ccivil_03/_Ato2015-2018/2016/Lei/L13341.htm>. Acesso em: 20 de dezembro de 2016.

Lei $\mathrm{n}^{\mathrm{o}} 11.516$, de 28 de agosto de 2007. Disponível em: <http://www.planalto.gov.br/ccivil_03/_ato2007-2010/2007/lei/111516.htm>. Acesso em: 20 de dezembro de 2016.

Lei $\mathrm{n}^{\mathrm{o}}$ 10.685, de 10 de abril de 2004. Disponível em: $<$ http://www.planalto.gov.br/ccivil_03/_Ato2004-2006/2004/Lei/L10.865.htm>. Acesso em: 20 de dezembro de 2016.

Lei $\mathrm{n}^{\mathrm{o}}$ 9.985, de 18 de julho de 2000. Disponível em: <http://www.planalto.gov.br/ccivil_03/LEIS/L9985.htm>. Acesso em: 20 de dezembro de 2016.

Lei $\mathrm{n}^{\mathrm{o}}$ 7.668, de 22 de agosto de 1988. Disponível em: $<$ https://www.planalto.gov.br/ccivil_03/LEIS/L7668.htm>. Acesso em: 20 de dezembro de 2016.

Decreto $\mathrm{n}^{\mathrm{o}}$ 4.887, de 20 de novembro de 2003. Disponível em: $<$ http://www.planalto.gov.br/ccivil_03/decreto/2003/D4887.htm>. Acesso em: 20 de dezembro de 2016.

Decreto $\mathrm{n}^{\mathrm{o}}$ 8.183, de 17 de janeiro de 2014. Disponível em: <http://www.planalto.gov.br/ccivil_03/_Ato2011-2014/2014/Decreto/D8183.htm>. Acesso em: 20 de dezembro de 2016.

Decreto Legislativo n ${ }^{\circ} 044$ (Câmara dos Deputados), de 5 de novembro de 2008. Disponível em: <http://www.camara.gov.br/sileg/integras/460993.pdf>. Acesso em: 20 de dezembro de 2016. 
Instrução Normativa $n^{\circ}$ 20, de 20 de dezembro de 2005 (Instituto Nacional de

Colonização e Reforma Agrária (Incra)). Disponível em: https://www.legisweb.com.br/legislacao/?id=76177. Acesso em: 20 de dezembro de 2016.

Instrução Normativa ${ }^{\circ}$ 49, de 29 de setembro de 2008 (Instituto Nacional de Colonização e Reforma Agrária (Incra)). Disponível em: http://www.incra.gov.br/sites/default/files/uploads/institucionall/legislacao--/atosinternos/instrucoes/in49_290908.pdf. Acesso em: 20 de dezembro de 2016.

Instrução Normativa $n^{\circ}$ 57, de 20 de outubro de 2009 (Instituto Nacional de Colonização e Reforma Agrária (Incra)), aprovada ad referendum, pela Portaria Incra-P $\mathbf{n}^{\mathrm{o}}$ 315, de 20 de outubro de 2009. Disponível em: http://www.palmares.gov.br/wpcontent/uploads/2010/11/legis12.pdf. Acesso em: 20 de dezembro de 2016.

Portaria $\mathrm{n}^{\circ} 14$ (Ministério da Justiça), de 9 de janeiro de 1996. Disponível em: http://www.funai.gov.br/arquivos/conteudo/dpt/pdf/portaria14funai.pdf. Acesso em: 20 de dezembro de 2016.

Portaria n ${ }^{\circ} 6$ (Fundação Cultural Palmares), de $1^{\circ}$ de março de 2004. Disponível em:

http://www.cpisp.org.br/htm/leis/page.aspx?LeiID=141. Acesso em: 20 de dezembro de 2016

Portaria $n^{\circ} 98$ (Fundação Cultural Palmares), de 26 de novembro de 2007. Disponível em: http://www.palmares.gov.br/wp-content/uploads/2010/11/legis21.pdf. Acesso em: 20 de dezembro de 2016.

Convenção no 169 (Organização Internacional do Trabalho), de 26 de junho de 1989. Portaria $n^{\circ} 98$ (Fundação Cultural Palmares), de 26 de novembro de 2007. Disponível em: http://www.palmares.gov.br/wp-content/uploads/2010/11/legis21.pdf. Acesso em: 20 de dezembro de 2016.

BECKER, Howard. Segredos e Truques da Pesquisa. Tradução Maria Luiza X. de A. Borges. Revisão técnica Karina Kuschnir. - Rio de Janeiro: Zahar, 1998.

BOBBIO, N. O futuro da democracia; uma defesa das regras do jogo, Tradução de Marco Aurélio Nogueira. — Rio de Janeiro: Paz e Terra, 1984. 171 p. 
BOURDIEU, P. Ofício do Sociólogo - Metodologia da Pesquisa na Sociologia. Pierre Bourdieu, Jean-Claude Chamboredon e Jean-Claude Passeron. Tradução Guilherme João de Freitas Teixeira. - 8. ed. - Rio de Janeiro: Editora Vozes, 1999. 328 p.

CASSIRER, E. O mito do estado. Tradução de Daniel Augusto Gonçalves. - Lisboa: Publicações Europa-América, 1946.

CHOMSKY, Noam. Razões de estado. Tradução Vera Ribeiro. - Rio de Janeiro: Record, 1970.

CZARNIAWSKA-JOERGES, B. Narrating the Organization: Dramas of Institutional Identity. Chicago: The University of Chicago, 1997. 233p.

COSTA, B. A. Controle Judicial de Políticas Públicas e o Processo Constitucional: gestão processual, negociação e soluções. - Curitiba: Juruá, 2015. 148 p.

DAHL, R. A.; LINDBLOM, C. Política, Economia e Bem Estar Social (Planejamento e Sistemas Político Econômicos reduzidos a processos sociais básicos). Tradução de Ruy Jungman. Harper \& Row, Publishers Inc. - Rio de Janeiro: Editora Lidador, 1971. 519 p.

DAHL, R. A. Análise Política Moderna. Tradução de Sérgio Bath. - Brasília, 2. ed. Editora Universidade de Brasília, 1976.

A Moderna Análise Política. - Rio de Janeiro: Editora Lidador, 1956.

. Um prefácio à democracia econômica. Tradução de Ruy Jungman. Rio de Janeiro: Jorge Zahar Editor, 1985. 156 p. Paulo, 1997.

Poliarquia, Participação e Oposição.Tradução Célio Mauro Paciornick, - São

DALLARI. D. A. Elementos de teoria geral do estado, 2. ed. atual. - São Paulo: Saraiva, 1998. 307 p.

DE MASI, Domenico. O Futuro chegou. Modelos de vida para uma sociedade desorientada. Tradução Marcelo Costa Sievers. 1. ed. Rio de Janeiro: Casa da Palavra, 2014 
DI PIETRO, M. S. Z. Direito administrativo. 29. ed. rev. atual. e ampl. - Rio de Janeiro: Forense, 2016. 1088 p.

ECO, U. Como fazer uma tese. Tradução Gilson César Cardoso de Souza, 25. ed. (Coleção Estudos; 85/dirigido por J. Guinsburg). - São Paulo: Perspectiva, 2014. 174 p.

FERRAJOLI. L. Garantismo, hermenêutica e (neo) constitucionalismo - um debate com Luigi Ferrajoli. Luigi Ferrejoli, Lenio Luiz Strech e André Karam Trindade (organizadores). Porto Alegre: Livraria do Advogado, 2012. 260 p.

FEYERABEND. P. K. Contra o método. Tradução Cézar Augusto Mortari. 2. ed. - São Paulo: Editora Unesp, 2003.

FREITAS, J. Discricionariedade administrativa e o direito fundamental à boa administração pública. - São Paulo: Malheiros Editores, 2007.

A hermenêutica jurídica e a ciência do cérebro: como lidar com os automatismos mentais. Revista da Ajuris, v. 40, n. 130, julho 2013, p. 223. Disponível em http://www.ajuris.org.br/OJS2/index.php/REVAJURIS/article/view/297. Acesso em 28/12/2016.

GALBRAITH, J. K. A Sociedade Justa, uma perspectiva humana. Tradução de Ivo Korytowski. - Rio de Janeiro: Campus, 1996. 175 p.

GODOY, A. S. M. Domesticando o leviatã: litigância intra-governamental e presidencialismo de articulação institucional. São Paulo: Universidade de São Paulo, 2012. 380 p.

.A Consultoria-Geral da União. Revista da AGU, ano XII, n. 40, p. 4360, jul/set.- Brasília: AGU, 2014. Disponível em: $<$ http://seer.agu.gov.br/index.php/AGU/article/view/419/412>. Acesso em 18 de outubro de 2016.

HALPERN, C.; LASCOUMES, P; LE GALÈS, P. L'instrumentation de l'action publique: controverses, résistances, effects. Paris: Presses de Sciences P, 2014. 520 p. 
HAM, C.; MICHAEL, J. The policy process in the modern capitalist state, 2. ed. Londres: Harvester Wheatsheaf, 1993. 210 p.

HOWLETT, M. Política pública: seus ciclos e subsistemas: uma abordagem integradora./ Michael Howlett, M. Ramesh, Anthony Perl. Tradução técnica Francisco G. Heidermann. - Rio de Janeiro: Elsevier, 2013. 164p.

KELSEN, H. Teoria Pura do Direito. Versão condensada pelo próprio autor. Tradução J. Cretella Jr. e Agnes Cretella. 9. ed. revista. São Paulo: Editora Revista dos Tribunais, 1934. $205 \mathrm{p}$.

KELSEN, H. Teoria Geral do Direito e do Estado. Tradução Luís Carlos Borges. 3. ed. São Paulo: Martins Fontes, 1945. 335 p.

KUHN, T. A estrutura das revoluções científicas. São Paulo: Editora Perspectiva, 1998.

LATOUR, B. Jamais fomos modernos. Tradução Carlos Irineu da Costa. -São Paulo: Editora 34, 1994.

Reagregando o social, uma introdução à teoria do ator-rede. Tradução Gilson César Cardoso de Sousa - Salvador: Edufba, 2012.

LE GALÈS, P.; VEZINAT, N.; RECOMPOSÉ, L. La Vie des idées. Paris: Presses universitaires de France, 2014. 112 p.

LÚCIO, M: DAROIT, D.: BESSA, L. F. M.; ABREU, A. L.. Sentidos e Significados de se Planejar Estrategicamente nas Organizações Públicas - Planejamento Estratégico Sociotécnico (PLANES): análise de uma experiência. Salvador: Revista NAU Social - v.5, n.9, p. 151-160 Novembro 2014 / Abril 2015.

LÚCIO, M.; COELHO, M. L. M. M. A Advocacia Pública Federal nas Metas do Centenário - A Mediação como instrumento de gestão. Debates em Direito Público, Revista de Direito dos Advogados da União. - Brasília, 2010.

LÚCIO, M.; RODRIGUES, S. M. L. R. Políticas de acesso à justiça: mediação. Revista O Social em Questão, Ano XIX, nº 36, Rio de Janeiro: PUC, 2016. 
MEDAUAR. O. Direito administrativo moderno. 19. ed. rev. e atual. - São Paulo: Editora Revista dos Tribunais, 2015. 507 p.

MEIRELLES, Hely Lopes. Direito Administrativo Brasileiro. 42. ed. - São Paulo, Malheiros, 2016.

MILOVIC, Miroslav. Política e metafísica. São Paulo: Editora Max Limonard, 2017.

NORTH, D. C. Institutions, institutional change and economic performance - Political economy of institutions and decisions. New York: Cambridge University Press, 1990.

O'DONNELL, G. Democracia, agência e estado: teoria com intenção comparativa. Tradução Vera Josvelyne. - São Paulo: Paz e Terra, 2010. 314 p.

Análise do autoritarismo burocrático. Tradução Cláudia Schilling. - Rio de Janeiro: 1. ed. Buenos Aires: Prometeo Libros, 1973.

O’DONNELL, Guillermo \& REIS, Fábio Wanderley. A democracia no Brasil - dilemas e perspectivas. - São Paulo: Vértice, ed. Revista dos Tribunais, 1988.

O’DONNELL, G. Democracia delegativa. 1 ed. - Buenos Aires: Prometeo Libros, 2011.

PIKETTY, Thomas. Capital no século XXI. Tradução Mônica Baumgarten de Bolle. - 1. ed. - Rio de Janeiro: Intrínseca, 2014.

A economia da desigualdade. Tradução André Telles. - 1. ed. - Rio de Janeiro: Intrínseca, 2015.

PUTNAM, R. D. Comunidade e democracia: a experiência da Itália moderna. Tradução Luiz Alberto Monjardim. 3 ed. Rio de Janeiro: Editora FGV, 1993.

SARLET, I. W. Dignidade (da pessoa) humana e direitos fundamentais na Constituição federal de 1988. 10. Ed. Rev. atual. e ampl. - Porto Alegre: Livraria do Advogado Editora, 2015. $200 \mathrm{p}$.

SILVA, J. A. Curso de Direito Constitucional Positivo. 39. ed. rev. Atual. Até a Emenda Constitucional n. 90, de 15.9.2015. - São Paulo: Malheiros, 2016. 936 p. 
SIMMEL, G. Ensaios sobre teoria da história. Tradução Estela dos Santos Abreu. Rio de Janeiro: Contraponto, 1917. 107p.

TOCQUEVILLE, A. Igualdade Social e Liberdade Política: uma introdução à obra de Alexis de Tocqueville. Tradução Cícero Araújo. São Paulo: Editora Nerman,1988.

VIEIRA JUNIOR, R. J. A. A Advocacia Pública Consultiva Federal e a Sustentabilidade Jurídico-Constitucional das Políticas Públicas: Dimensões, Obstáculos e Oportunidades na atuação da Advocacia-Geral da União. Revista da AGU. Ano VIII, Número 19, Brasília (DF), jan/mar. 2009.

WEBER, M. Escritos políticos. Tradução Régis Barbosa e Karen Elsabe Barbosa.- 1. ed. São Paulo: Folha de São Paulo, 2015.

WU, Xun; RAMESH, M.; HOWLETT, M.; FRITZEN, S. Guia de políticas públicas: gerenciando processo. Tradução Ricardo Avelar de Souza. - Brasília, 2014. 


\section{ANEXO I - FORMULÁRIO DE ENTREVISTA}

Senhor(a) Entrevistado(a),

Esta solicitação de entrevista objetiva a registrar, como pesquisa acadêmica, a experiência acumulada na Administração Pública, por trabalho desenvolvido pela pesquisadora junto à Advocacia-Geral da União, assunto documentado nos autos do processo administrativo $\mathrm{n}^{\circ}$ 00400.004590/2007-11.

Sou advogada da União e mestranda do programa de Pós-Graduação em Desenvolvimento, Sociedade e Cooperação Internacional da Universidade de Brasília e o resultado da pesquisa instruirá a sua dissertação, com o tema "Discricionariedade e litigância intragovernamental na gestão de políticas públicas."

Antecipadamente, agradeço pela atenção dispensada a esta solicitação.

\section{Sávia Rodrigues}

Brasília, 31 de outubro de 2016

\section{ENTREVISTADO:}

\section{ÓRGÃO OU ENTIDADE:}

1. O(A) senhor(a) recorda o momento da determinação do Presidente da República para que a AGU deflagrasse um processo de conciliação, em tese, para a solução dos diversos conflitos envolvendo a regularização fundiária de comunidades indígenas e quilombolas em $2007 ?$

2. Sob o seu ponto de vista, quais eram os problemas mais graves que ensejaram a constituição do grupo de trabalho?

3. Como era o ambiente institucional na sua área de atuação?

4. Na sua percepção, havia algum conflito de políticas públicas? Em caso de considerar que havia conflito de políticas públicas, qual seriam as razões desse conflito?

5. Como o(a) senhor(a) avalia as atividades da AGU na coordenação do grupo de trabalho? 
6. Internamente na sua instituição, havia algum grau de conciliação interna quanto ao assunto que o grupo de trabalho encaminhava?

7. Na sua opinião, os resultados do grupo de trabalho trouxeram alguma contribuição para a implementação das políticas públicas destacadas?

8. Em caso de entendimento de que o grupo de trabalho não trouxe resultados, na sua opinião, quais seriam as causas desse insucesso?

9. Em caso de resposta afirmativa quanto à existência de contribuições do grupo de trabalho para a implementação de políticas públicas, na sua opinião, quais seriam as razões desse êxito?

10. Na sua opinião, o que chamou a atenção no grupo de trabalho, em que medida o trabalho jurídico realizado pelo grupo de trabalho teve relevo para a construção das soluções em prol da conciliação de conflitos administrativos?

11. $\mathrm{O}$ (A) senhor(a) poderia levantar outros aspectos que julga importantes para solução de conflitos administrativos?

12. Que avaliação o(a) senhor(a) faz da consulta pública às comunidades quilombolas levada a efeito do grupo de trabalho?

13. $\mathrm{O}(\mathrm{A})$ senhor(a) quer destacar algum outro aspecto desse trabalho? 


\section{ANEXO II - ENTREVISTAS REALIZADAS}

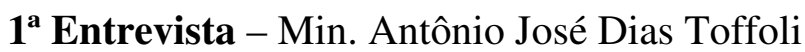

Ministro do Supremo Tribunal Federal, ex-Advogado-Geral da União.

No exercício da legalidade estrita, na condição de Advogado-Geral da União percebeu a possibilidade de a Instituição arbitrar a configuração de efetivos conflitos administrativos, em que havia uma demora na solução. Tradicionalmente, a AGU tinha competência para arbitrar, segundo observava na sua experiência junto à SAJ - Casa Civil.

Em que pese a previsão legal, a AGU atuava ad hoc e a decisão foi institucionalizar a atividade de conciliação e arbitragem, num primeiro momento apenas entre os órgãos federais e, em seguida, com estados e municípios, para estes últimos, naturalmente, sem a possibilidade de arbitrar.

Relatou haver solicitado um levantamento sobre processos em andamento no STF, o que totalizou aproximadamente 147 ações de estados em face da União, o que atualmente não mais existe. No STJ foram detectados cerca de 400 processos com as mesmas partes.

Solucionar as divergências administrativas no Judiciário seria desperdiçar a possibilidade de atuação da AGU. Decidiu por institucionalizar a CCAF, para que assumisse paulatinamente os processos existentes na administração e as demandas em curso no Judiciário, a começar pelo STF. Os precedentes da CCAF foram estimulando a credibilidade progressiva por crédito na cultura da conciliação, com a desjudicialização dos conflitos.

Referiu como exemplo de arbitragem na CCAF a distribuição de royalties entre estados, envolvendo matéria judicializada entre União, Petrobras, ANP e Estado do Rio de Janeiro, com celeridade e economia de recursos públicos.

A expansão da CCAF trouxe favorável repercussão no Judiciário, com celeridade, otimização do tempo e de recursos públicos.

A cultura da conciliação deve ser iniciada desde o curso jurídico, onde ainda impera a cultura do litígio, derrotar o inimigo e vê-lo humilhado. É necessário mudar a cultura do advogado para o litígio, para a disputa, para levar a solução dos problemas sempre ao Judiciário, mediante a terceirização dos problemas.

Alternativamente, a cultura da conciliação implica ser parte da solução e a AGU tomou a decisão neste sentido, de ser parte da solução do problema. 
Quanto à questão quilombola do estudo de caso da pesquisa, as divergências decorreram de um Parecer da lavra do Consultor-Geral da União, Dr. Lauro Volkmer de Castilho, que aproximara o processo de regularização fundiária de comunidades quilombolas ao procedimento previsto para comunidades indígenas. Uma questão relevante foi a utilização do verbo do dispositivo constitucional no tempo presente.

O Incra vinha adotando os procedimentos da Funai para a titulação de comunidades quilombolas, estabelecendo critérios de demarcação que divergiam da previsão constitucional, podendo inviabilizar a própria efetivação do decreto. A interpretação a ser dada exige uma diferença de demarcação e a situação era conflito não apenas no poder Executivo, mas no próprio Parlamento, tanto que o assunto veio a ser objeto de uma ADI em face do Decreto $n^{\circ} 4.887$, de 2003.

A própria Seppir acolheria o entendimento de que o procedimento adotado pelo Incra não atendia as necessidades das comunidades quilombolas, interferindo na consecução de suas políticas públicas.

O Incra tinha uma postura mais radical e, de certa forma, seria este um elemento referente a estrutura burocrática para justificar competência e promover a eternização de competências, que apontariam para a perenização da autarquia, sem a solução de questões conflitantes.

O Ministro referiu um exemplo de evento na Itália. Estado Unitário, conta com 275 senadores, tendo sido suscitada uma proposta de redução para 100 senadores, com a supressão de uma instância administrativa de hierarquia burocrática, de uma estrutura de quatro. $\mathrm{O}$ assunto foi aprovado pela administração, mas não passou numa consulta popular porque este enxugamento da máquina administrativa implicaria desemprego.

Este assunto chamou especialmente a atenção pela associação, no caso brasileiro, com a Secretaria de Reforma do Judiciário, com o que concordou. 


\section{2 a Entrevista - Deborah Duprat}

Subprocuradora-Geral da República

Após uma curta exposição sobre os motivos da entrevista, a Subprocuradora-Geral da República Deborah comentou que se pôs de acordo com a consulta realizada pela AGU, por perceber no ex-Consultor-Geral da União Ronaldo Vieira Jr., uma pessoa com experiência em lidar com movimentos sociais, a configuração de bons propósitos. Contudo, entende que o processo de consulta se realizou de uma maneira forçada, ainda que válida por ter sido a primeira iniciativa a levar a cabo o procedimento de consulta previsto na Convenção OIT $n^{\circ}$ 169. Comentou que o procedimento exige um requisito indispensável, que é a boa-fé, e que a ativa participação dos consultados é muito importante.

Explicou que, antes do procedimento em relevo, o Brasil havia sido indagado, pela OIT, sobre quais as populações de seu território estariam abrangidas pela sua Convenção OIT n 169 e a resposta havia sido que apenas as comunidades indígenas. Desta forma, a consulta realizada ampliou as possibilidades da consulta, afirmando as comunidades quilombolas como sujeitos dos direitos previstos na Convenção OIT.

A Subprocuradora-Geral da República Deborah comentou que a consulta foi a experiência mais ética que o governo já adotou, embora hoje os parâmetros da Corte Interamericana de Direito Humanos prevejam procedimentos para a consulta de uma forma mais ampla que a realizada, entende que os debates produzidos foram longos e produtivos, para aquele momento.

Comentou ter ressalva ao grupo de sistematização, porque as comunidades quilombolas fizeram várias observações que não foram consideradas ao final, no texto publicado. Pela sua recordação o grupo de sistematização se circunscreveu em anotar as divergências, sem apreciar ou acolher, quando deveria ter dado uma resposta às comunidades. Praticamente, é como se não tivesse havido a consideração pelo que as comunidades pleitearam.

A vantagem da consulta foi mais simbólica e formal, sem o convencimento das comunidades.

À consulta coube um impacto positivo, ainda que limitado. 
Sobre a discricionariedade, que comentei quando expressei sobre o tema do meu trabalho, Subprocuradora-Geral da República Deborah observou que não existe mais discricionariedade, mas pluralismo e interesse público, máxima efetivação de todos os direitos.

Entende que o papel da AGU não seria de realizar a conciliação, porque os assuntos em relevo não ensejam uma negociação, não são um processo negocial, mas de conformação constitucional. É um trabalho jurídico e não gerencial, de conformar a interpretação normativa para atender os ditames da Constituição, sem escolhas. Disse que há um equívoco da AGU em cem por cento dos casos, ao procurar promover conciliação, porque não se podem ceder direitos que não lhe pertencem. Que a AGU deve procurar a máxima efetividade dos direitos fundamentais, no plano jurídico, não negocial.

Sobre a Instrução Normativa, resultado das atividades do GT, entende que instituiu excesso de burocracia que inviabiliza a regularização fundiária de comunidades quilombolas. Ao prever a oitiva de muitos órgãos, tornou o procedimento custoso, burocrático e difícil.

Os processos lentos geram a inércia a falta de vontade política.

Destacou que o ponto positivo foi a apropriação da consulta da Convenção OIT no 169 pelas comunidades quilombolas.

Narrou que o governo instituiu um grupo de trabalho para disciplinar a Convenção OIT, mas os trabalhos não vingaram.

Sabe que a IN foi modificada muitas vezes, sem o procedimento de consulta.

Relatou que os antropólogos também reclamaram sobre a burocratização do Relatório Técnico de Identificação e Delimitação (RTID).

Chamou a atenção para os entendimentos expedidos pela Corte Interamericana de Direitos Humanos, que não aceita a consulta realizada como tendo atendidos os seus parâmetros mínimos, porque gerou um processo de regularização custoso e burocrático, carente de vontade política. 
$3^{\text {a }}$ Entrevista - Ronaldo Jorge Araujo Vieira Junior

Consultor Legislativo do Senado Federal, ex-Consultor-Geral da União

Pedi que ressaltasse os pontos fortes e pontos fracos do trabalho desenvolvido pelo GT Quilombolas e Indígenas.

A demanda realizada pelo Presidente da República ao Advogado-Geral vinha ao encontro de uma determinação interna de institucionalização dos trabalhos de conciliação na AGU.

Havia testemunhado a construção política delicada para a edição do Decreto $n^{\circ} 4.887$, de 2003, e reconhecia que havia dois grandes pontos de divergência para a questão da titulação das comunidades indígenas e quilombolas, junto ao Gabinete de Segurança Institucional e Ministério da Defesa em face de outro bloco administrativo composto por Incra, FCP, Seppir. Existia, ainda, a questão ambiental, com a criação de unidades de conservação em área de sobreposição geográfica com demandas por titulação dessas comunidades.

O ponto mais delicado da divergência ocorreu com a publicação de matéria jornalística, questionando os procedimentos administrativos de reconhecimento de comunidades quilombolas, pela FCP. A reportagem abordou uma comunidade na Bahia.

No contexto dos trabalhos, iniciados em 27 de julho de 2007, veio a ser criado o Instituto Chico Mendes de Conservação da Biodiversidade, pela Lei n ${ }^{\circ} 11.516$ (BRASIL, 2007).

O ambiente de criação do grupo de trabalho informal e interministerial era de muita desconfiança e resistência de todos os lados. Os integrantes tinham as suas posições bem definidas e contrapostas.

Um dos esforços mais delicados foi procurar um encaminhamento de consenso.

Os levantamentos de posições as mais diversas e a composição de um encaminhamento que não interferisse da higidez de um decreto defendido no STF pela AGU tem repercussão ainda hoje, quando se postula a inserção na titulação quilombola nas regras do estatuto da igualdade racial e mais uma vez, por coerência, se recomenda a sua não adoção, por gerar divergência com a posição jurídica adotada de defesa do Decreto autônomo nos autos da ADI $n^{\circ} 3.239$. 
Um marco relevante foi a aprovação, em reunião de Ministros de Estado com o Presidente da República da consulta às comunidades quilombolas.

A definição do procedimento contou com a participação do MPF e de representação das comunidades, em reunião no auditório da Escola da AGU.

A Subprocuradora-Geral da República Deborah Duprat mencionou que o procedimento de consulta havia passado por avaliação de integrantes da Sexta Câmaras, que havia deliberado, por maioria, quanto à possibilidade da proposta da AGU. Ressaltou a sua divergência, mas seu acatamento da decisão, estimulando a que as comunidades aceitassem a proposta da AGU de realizar a consulta quanto à alteração da Instrução Normativa do Incra. Sua participação no procedimento foi relevante para dar credibilidade aos trabalhos e a legitimá-lo. Compareceu às reuniões de consulta em Luziânia e, ao final dos trabalhos, reconheceu que as atividades desenvolvidas foram relevantes e fizeram marco.

Mencionou a primeira tentativa sem êxito de fazer a consulta, em dezembro de 2007, só tendo sido possível a consulta em abril de 2008.

Diante de questionamentos de comunidades quilombolas de que não tinha havido transparência, foi relevante a composição formal de todo o trabalho, com a construção formal de processo, com emissão de correspondências com aviso de recebimento, com a completa cronologia e organização dos trabalhos, registros das reuniões, registros fotográficos e filmagens.

Além da relevância da consulta, os trabalhos de sistematização, em grupo de formação paritária, governo e quilombolas também importou para a credibilidade dos trabalhos.

Pontos relevantes favoráveis:

Formalidade do procedimento

Construção laboriosa do consenso

Definição dos critérios preliminares do trabalho

Realização da consulta

Construção de trabalho conjunto e respeito a todas as participações 
$4{ }^{\text {a }}$ Entrevista - Fernando Luiz Albuquerque Faria

Advogado da União, atualmente, lotado e em exercício na Consultoria-Geral da União da Advocacia-Geral da União, especificamente no Departamento de Análise de Atos Normativos, porém, à época, dos fatos de que tratam o Despacho do Excelentíssimo Advogado-Geral da União datado de 22 de agosto de 2008, encontrava-se lotado e em exercício na Subchefia para Assuntos Jurídicos da Casa Civil da Presidência da República.

Sim, recordo desse momento. Era um momento de muitos questionamentos acerca do alcance do disposto no art. 68 do ADCT e no Decreto $n^{\circ} 4.887$, de 2003, e dúvidas acerca dos limites de atuação dos órgãos responsáveis pela identificação, reconhecimento, demarcação e titulação de terras ocupadas por remanescentes de comunidades dos quilombos.

Dúvidas acerca dos limites de atuação dos órgãos responsáveis pela identificação, reconhecimento, demarcação e titulação de terras ocupadas por remanescentes das comunidades dos quilombos, mormente do INCRA e acerca dos limites na elaboração por esta Autarquia de Relatório de Identificação e Delimitação (RTID). Além disso, havia questionamentos acerca da equiparação do direito de reconhecimento da propriedade definitiva das terras ocupadas por remanescentes das comunidades dos quilombos (ADCT, art. 68) com o direito às terras tradicionalmente ocupadas pelos índios $\left(\mathrm{CF} / 88, \S 1^{\circ}\right.$ do art. 231), e também havia conflitos decorrentes de sobreposição das terras ocupadas por quilombolas com algumas áreas afetadas pelo Poder Público e com título de domínio particular.

O ambiente institucional da Casa Civil da Presidência da República era de busca de uma solução consensuada, no qual se deveria buscar uma solução que, ao mesmo tempo, pudesse resguardar a política pública social de titulação de terras ocupadas por comunidades remanescentes de quilombos e resolver os conflitos de sobreposição de utilização de tais terras.

Sim, havia diversos conflitos, tendo em vista a sobreposição de terras delimitadas pelo Incra com áreas ocupadas ou tituladas a particulares ou afetadas pelo Poder Público para outras finalidades (criação de unidades de conservação ambiental, utilização por organizações militares e demarcação de terras indígenas). Além disso, havia 
questionamentos acerca dos procedimentos utilizados pelo Incra na identificação e delimitação das terras ocupadas por remanescentes quilombolas, mormente sua equiparação ao direito das terras tradicionalmente ocupadas por indígenas.

Foi a AGU que possibilitou que se fizesse a primeira consulta pública a comunidades tradicionais para fins de alteração de ato normativo, conforme previsto no artigo $6^{\circ}$, item 1 , letra "a", da Convenção OIT n ${ }^{\circ} 169$, incorporada ao ordenamento jurídico brasileiro pelo Decreto ${ }^{\circ} 5.051$ (BRASIL, 2004).

Assim, a atuação da AGU como mediadora e organizadora da consulta pública foi essencial e histórico.

Sim, havia, conforme já respondido anteriormente, uma determinação de se buscar uma resolução consensuada.

Sim, eis que a mencionada Consulta Pública com a participação de representantes de Comunidades Remanescentes de Quilombos de diversas localidades do Brasil e as atividades do grupo de trabalho composto por diversos órgãos da Administração Pública federal resultaram na propositura de uma nova instrução normativa para o Incra regulamentando o procedimento para identificação, reconhecimento, delimitação, demarcação, desintrusão, titulação e registro das terras ocupadas por remanescentes das comunidades dos quilombos, e tal proposta normativa resultou na expedição da $\mathrm{IN} \mathrm{n}^{\circ}$ 57, de 20 de outubro de 2009, que, além de, diferenciar a titulação de terras ocupadas por remanescentes de quilombos do direito das terras tradicionalmente ocupadas por indígenas, estabeleceu mecanismos de solução de conflitos sejam em relação a particulares, sejam em relação a outros órgãos e entidades públicas. 
5 a Entrevista - Marcela Albuquerque Maciel

Procuradora Federal, ex-Consultora Jurídica junto ao Ministério do Desenvolvimento Agrário

Não diretamente. Mas esse foi o fundamento apresentado para a criação do Grupo de Trabalho (a determinação foi em momento próximo ao do estabelecimento do Grupo).

Divergência entre órgãos e entidades da Administração Pública Federal, do qual destaca (em razão da sua atuação à época) o conflito entre o GSI e o Incra (MDA).

O Incra e o MDA tinham posicionamento firme e consensual acerca da constitucionalidade, interpretação e aplicação do Decreto n ${ }^{\circ} 4887$, de 2003 , nos termos em que atuava o Incra.

Acredita que no caso específico do GT o conflito foi mais de institucionalidades do que de políticas públicas em si.

Inédita, firme, organizada e corajosa, marcando a AGU como o espaço institucional dentro da Administração Pública para a gestão e solução de conflitos.

Sim. Fortaleceu o entendimento acerca da constitucionalidade do Decreto $n^{\circ} 4.887$, de 2003. Houve o reconhecimento da aplicação da Convenção OIT n ${ }^{\circ} 169$ às comunidades quilombolas (do qual o ponto de destaque foi a realização da Consulta Pública).

Foi um espaço franco de diálogo interinstitucional, no qual os conflitos foram visibilizados e possíveis soluções partilhadas.

O reconhecimento da constitucionalidade do Decreto $\mathrm{n}^{\circ} 4.887$, de 2003, e da aplicação da Convenção OIT $\mathrm{n}^{\circ} 169$ às comunidades quilombolas (duas construções jurídicas) foi ponto de partida essencial para a construção de soluções em prol da conciliação dos conflitos administrativos.

Importa que os representantes das instituições envolvidas detenham conhecimento do tema e estejam empoderados de alguma forma para representar o órgão/entidade. Trocas frequentes de representantes costumam dificultar os trabalhos de conciliação.

A consulta pública realizada foi pioneira não só em razão de seu ineditismo, mas também ao reconhecer de maneira expressa a aplicação da Convenção OIT n ${ }^{\circ} 169$ às comunidades quilombolas. Foi um espaço de reconhecimento do outro. De respeito aos interesses daqueles a quem as políticas públicas em questão estão direcionadas. 


\author{
$6{ }^{\text {a }}$ Entrevista - Renata Leite \\ Ex-Assessora Especial Min. do Desenvolvimento Agrário
}

Havia uma demanda precedente, desde 2003, período de elaboração do Decreto $n^{\circ}$ 4.887, de 2003. A Casa Civil impediu o Incra de regulamentar a regularização fundiária das comunidades quilombolas. O Decreto foi questionado pelo GSI. Causava insatisfação que as comunidades tivessem que se adequar ao ritmo de regularização fundiária do Incra. Havia entraves na aplicação do Decreto pela FCP, o que acabou gerando a sua perda de competência para a regularização. Registrava-se uma disputa interna no Poder Executivo, por competência e poder entre os órgãos. A FCP tentava manter a sua competência, mas tinha havido problemas inclusive judiciais.

Existia uma forte demanda política por espaços constituídos, mesmo no âmbito dos órgãos que deveriam atender as políticas em favor das comunidades quilombolas: Seppir, FCP, MDA e Incra. E entre estes e MMA e GSI. Com estes havia o maior gargalo. Os órgãos que atendiam as políticas paras as comunidades quilombolas, apesar das dificuldades de sintonia, conseguia alguma articulação para o enfrentamento com o MMA e com o GSI principalmente. Na vigência do grupo de trabalho, Seppir, FCP, MDA e Incra faziam ajustes prévios, para enfrentarem as disputas com as áreas de segurança e ambiental.

Mesmo no Incra havia muitas disputas sobre a questão do fluxo de trabalho para a regularização fundiária de comunidades quilombolas porque o Incra já possuía um fluxo de trabalho para a regularização fundiária em regra, que queria aplicar às comunidades, enquanto estas consideravam que o procedimento a ser aplicado era diferenciado. De fato, a questão só foi pacificada quando uma integrante de comunidades quilombolas, Dra. Givânia Silva, antes gestora na Seppir, assumiu a Diretoria de Reg. Fundiária para Com. Tradicionais, no Incra, implementando as políticas na concepção destas, em 2008. O Incra não queria alterar seus procedimentos de trabalho para atender de forma diferenciada as comunidades quilombolas.

Em determinados assuntos, a disputa da Seppir, FCP, MDA e Incra com o MMA era aplacada, para a defesa de interesses comuns, quando se fazia uma composição de forças, a depender do assunto. 
A fala dos representantes no grupo de trabalho destoava muito. A atuação da AGU era muito diferente dos gestores. Havia uma insatisfação com o fato de a AGU estar coordenando os trabalhos.

A insatisfação de estar a AGU na coordenação do GT decorria do fato de ser a controvérsia mais política do que jurídica. A própria norma estabelecida pelo trabalho do grupo sinalizou que as controvérsias políticas deveriam ser resolvidaS no âmbito da Casa Civil e apenas a jurídica pela AGU. A atuação da AGU tendia ser muito técnica e isto provocava insatisfação. A AGU não conhecia a abordagem política do assunto, até porque não é a sua área. A Seppir, FCP, MDA e Incra tentaram construir um consenso interno entre as áreas técnica e jurídica, para auxiliar nos encaminhamentos que se buscava dar no GT.

No MDA ocorria um consenso entre as áreas técnica e jurídica, o que se estendia ao Incra. Procuravam discutir previamente os assuntos e estabelecer um alinhamento para mais agilidade nas reuniões.

O aspecto mais relevante das atividades do GT foi a construção de uma metodologia de consulta, o que sucedeu em outros procedimentos no MDA. Embora não tenha havido nenhum outro procedimento de mesma envergadura, a construção do diálogo foi relevante inclusive para o prosseguimento das políticas, porque as comunidades adquiriram certa confiança na atuação com a Administração, houve a construção de um ambiente favorável à confiança e ao diálogo. O processo de consulta aliviou as tensões e deu margem para a credibilidade na atuação do MDA, onde atuava a entrevistada.

O longo transcurso dos trabalhos foi um aspecto negativo, acrescido da longa indefinição dos encaminhamentos que a política enfrentaria. Ainda hoje, submeter os assuntos à AGU gera muito tempo de indefinição e muito desgaste.

O ganho de credibilidade possibilitou espaço para institucionalizar a Coordenação no Incra, como comentado acima, e foi favorável para as comunidades quilombolas aceitarem a atuação institucional.

As comunidades quilombolas faziam uma crítica, de que o Incra estava terceirizando a sua competência para a AGU.

Não teve relevo, dada a natureza política e não jurídica do problema que deveria ser resolvido. Não havia dúvidas jurídicas a serem sanadas e as que havia corriqueiramente eram resolvidas pela Procuradoria Federal Especializada junto ao Incra. 
A perspectiva de que a coordenação do GT ficasse com a AGU era ruim, porque a Seppir, o Incra, a FCP e o MDA perdiam a governabilidade. A perspectiva era de que o governo federal não sabia como tratar adequadamente as políticas quilombolas, não possuía dados, não tinha como mensurar ou planejar e não tinha condições de tratar adequadamente a política. Nos estados de São Paulo e Pará havia mais experiência no assunto.

Era necessário conhecer efetivamente as demandas, saber sobre os problemas enfrentados pelas comunidades. Era um direito novo tratado de forma antiga, o que trazia muitas dificuldades. Tudo isto só trazia mais antagonismo e menos consenso.

A consulta com aquele formato do GT não mais se repetiu. Foi muito importante que as comunidades e o MPF tenham participado da construção da metodologia da consulta, deu mais legitimidade. A consulta foi uma inovação e a sua realização firmou um paradigma.

Nem na OIT chegou a ficar clara a natureza da consulta prevista em sua Convenção, se teria natureza deliberativa ou apenas de audição.

Houve um esforço de consulta em Alcântara (MA), mas nada semelhante ao que ficou consignado no GT.

$\mathrm{O}$ assunto quilombola foi acolhido como pauta da Administração, assim como a consulta, que ficou internalizada no serviço público.

Reforço que a consulta foi histórica e que firmou uma metodologia que fez relevo administrativo. 


\section{ANEXO III - Memória da Reunião Preparatória para a Consulta à nova IN (INCRA)}

Data: 24 de março de 2008

Local: Sala de Reuniões da Seppir

Horário: 17 às 19h30

Participantes:

José Lima - Conaq (SC)

Oriel Rodrigues - Conaq (SP)

Ronaldo dos Santos - Conaq (RJ)

Jhonny Martins - Conaq (MS)

Damião Braga - Acquilerj / Conaq (RJ)

Bernadete Lopes - FCP/MinC

Renata Leite - MDA

Paula Melo - MDA

Rui Leandro - Incra

Sandra Cabral - Seppir

Giovanni Harvey - Seppir

Bárbara Souza - Seppir

\section{Objetivo da Reunião:}

Consolidar a proposta de realização da Consulta Pública à nova Instrução Normativa do Incra; Dialogar com lideranças quilombolas a proposta da Consulta, tendo como base a proposta constituída pelo GT; avaliar a conjuntura atual, riscos, perdas e avanços; Discutir o formato de execução da consulta, visando facilitar a participação das comunidades quilombolas.

Principais pontos abordados na reunião:

- Deu-se início à reunião com a apresentação dos presentes.

- Posteriormente, foi apresentado o histórico dos trabalhos do Grupo Interministerial, coordenado pela AGU, que teve como papel elaborar uma proposta para Nova Instrução Normativa do Incra, a partir de demanda feita pelo gabinete do Presidente da República. Essa demanda surge como estratégia para fazer contraponto às argumentações presentes na Adin impetrada pelo antigo PFL (hoje Democratas) no Supremo Tribunal Federal com vistas a tornar inconstitucional do Decreto 4.887, de 2003.

- Relatou-se todo o processo de construção da Consulta Pública à Nova IN - INCRA elaborada pelo GT, cujos marcos são:

- A primeira proposta de Consulta foi agendada para duas etapas: $1^{\mathrm{a}}$ etapa, prevista para o dia 10/12/07, teria como objetivo a apresentação da Nova IN - INCRA; $2^{\mathrm{a}}$ etapa, prevista para o dia 17/12/07, seria voltada para a discussão do conteúdo com as representações quilombolas de todo país para finalizar uma proposta única ao texto da nova IN - INCRA; - Uma vez não compreendendo o processo como adequado à realização da Consulta, as representações quilombolas não se fizeram presentes à primeira proposta de Consulta $\mathrm{e}$ iniciaram um processo de diálogo para construção de nova proposta.

- No dia 19/12, em reunião de caráter informal entre algumas lideranças quilombolas e parte dos ministérios que compõem o GT, ficou decidido que a CONAQ encaminharia proposta de consulta para análise do GT, até o dia 15/01/08. Em razão dos recessos de fim 
de ano, a Conaq solicitou prorrogação de prazo, entregando a versão final de sua proposta à AGU no dia 15/02/08.

- O processo de manifestações por parte dos diversos órgãos que compõem o GT e a construção de uma proposta por parte do Governo, em diálogo com o colocado pela Conaq, foi finalizado com a presente reunião, realizada em 24/03/08, cuja proposta foi apresentada ao Movimento Quilombola.

- A proposta apresentada pelo governo ao movimento quilombola segue abaixo sistematizada:

\begin{tabular}{|c|c|c|c|}
\hline \multicolumn{4}{|c|}{$\begin{array}{c}\text { SEMINÁRIO SUL / SUDESTE } \\
\text { Data: } 1 \text { e } 2 / 04 / 08 \\
\text { Local: Auditório Incra (SP) (a confirmar) }\end{array}$} \\
\hline $\begin{array}{c}\text { Seminário } \\
\text { do } \\
\text { Sul/Sudeste }\end{array}$ & $\begin{array}{l}\text { Quantidade } \\
\text { de } \\
\text { participantes } \\
\end{array}$ & $\begin{array}{c}\text { Tipo de } \\
\text { deslocamento }\end{array}$ & Observação \\
\hline Estados & 100 pessoas & Aéreo e Terrestre & \\
\hline MG & 25 & Aéreo e Terrestre & $\begin{array}{l}\text { Será necessário custear } \\
\text { deslocamento até o } \\
\text { aeroporto }\end{array}$ \\
\hline SP & 25 & Terrestre & \\
\hline RJ & 10 & Terrestre & \\
\hline $\mathrm{ES}$ & 10 & Aéreo & $\begin{array}{l}\text { Será necessário custear } \\
\text { deslocamento até o } \\
\text { aeroporto }\end{array}$ \\
\hline $\mathrm{RS}$ & 15 & Aéreo & $\begin{array}{l}\text { Será necessário custear } \\
\text { deslocamento até o } \\
\text { aeroporto }\end{array}$ \\
\hline $\mathrm{SC}$ & 05 & Aéreo & $\begin{array}{l}\text { Será necessário custear } \\
\text { deslocamento até o } \\
\text { aeroporto }\end{array}$ \\
\hline PR & 10 & Aéreo e Terrestre & $\begin{array}{l}\text { Será necessário custear } \\
\text { deslocamento até o } \\
\text { aeroporto }\end{array}$ \\
\hline
\end{tabular}

\section{SEMINÁRIO NORTE / NORDESTE / CENTRO OESTE}

Data: 3 e 4/04/08

Local: CNTI (a confirmar)

\begin{tabular}{|c|c|c|c|}
\hline $\begin{array}{c}\text { Seminário } \\
\text { Norte/Nord } \\
\text { este/Centro } \\
\text {-Oeste }\end{array}$ & $\begin{array}{c}\text { Quantidade de } \\
\text { participantes }\end{array}$ & $\begin{array}{c}\text { Tipo de } \\
\text { deslocamento }\end{array}$ & Observação \\
\hline
\end{tabular}




\begin{tabular}{|c|c|c|c|}
\hline Estados & 215 pessoas & $\begin{array}{l}\text { Aéreo e } \\
\text { Terrestre }\end{array}$ & \\
\hline PA & 25 & Aéreo & $\begin{array}{l}\text { Será necessário custear } \\
\text { deslocamento até } \\
\text { aeroporto }\end{array}$ \\
\hline MA & 25 & Aéreo & $\begin{array}{l}\text { Será necessário custear } \\
\text { deslocamento até } \\
\text { aeroporto }\end{array}$ \\
\hline BA & 25 & $\begin{array}{c}\text { Terrestre e } \\
\text { Aéreo }\end{array}$ & $\begin{array}{l}\text { Será necessário custear } \\
\text { deslocamento até } \\
\text { aeroporto }\end{array}$ \\
\hline RO & 06 & Aéreo & $\begin{array}{l}\text { Será necessário custear } \\
\text { deslocamento até o } \\
\text { aeroporto }\end{array}$ \\
\hline RN & 10 & Aéreo & $\begin{array}{l}\text { Será necessário custear } \\
\text { deslocamento até } \\
\text { aeroporto }\end{array}$ \\
\hline MS & 10 & Aéreo & $\begin{array}{l}\text { Será necessário custear } \\
\text { deslocamento até } \\
\text { aeroporto }\end{array}$ \\
\hline GO & 09 & Aéreo & $\begin{array}{l}\text { Será necessário custear } \\
\text { deslocamento até } \\
\text { aeroporto }\end{array}$ \\
\hline PI & 15 & Aéreo & $\begin{array}{l}\text { Será necessário custear } \\
\text { deslocamento até } \\
\text { aeroporto }\end{array}$ \\
\hline $\mathrm{CE}$ & 09 & Aéreo & $\begin{array}{l}\text { Será necessário custear } \\
\text { deslocamento até } \\
\text { aeroporto }\end{array}$ \\
\hline $\mathrm{AL}$ & 10 & Aéreo & $\begin{array}{l}\text { Será necessário custear } \\
\text { deslocamento até } \\
\text { aeroporto }\end{array}$ \\
\hline TO & 06 & Aéreo & $\begin{array}{l}\text { Será necessário custear } \\
\text { deslocamento até } \\
\text { aeroporto }\end{array}$ \\
\hline $\mathrm{PB}$ & 10 & Aéreo & $\begin{array}{l}\text { Será necessário custear } \\
\text { deslocamento até } \\
\text { aeroporto }\end{array}$ \\
\hline SE & 10 & Aéreo & $\begin{array}{l}\text { Será necessário custear } \\
\text { deslocamento até } \\
\text { aeroporto }\end{array}$ \\
\hline $\mathrm{PE}$ & 20 & Aéreo & $\begin{array}{l}\text { Será necessário custear } \\
\text { deslocamento até } \\
\text { aeroporto }\end{array}$ \\
\hline
\end{tabular}




\begin{tabular}{|c|c|c|l|}
\hline AP & 10 & Aéreo & $\begin{array}{l}\text { Será necessário custear } \\
\text { deslocamento até o } \\
\text { aeroporto }\end{array}$ \\
\hline MT & 15 & Aéreo & $\begin{array}{l}\text { Será necessário custear } \\
\text { deslocamento até o } \\
\text { aeroporto }\end{array}$ \\
\hline
\end{tabular}

- Após a apresentação da proposta pelos representantes do Governo presentes à reunião, iniciou-se debate sobre a viabilidade administrativa de realizar um evento desse porte, tendo em vista as exigências administrativas para emissão de passagens e locação de espaço que demandam tempos superiores às datas previstas.

- A emissão de passagens, por exemplo, pressupõe um processo de no mínimo 10 dias corridos nos quatro órgãos que até o presente momento apresentaram disposição concreta em contribuir com os gastos da Consulta. Já a licitação do espaço demanda no mínimo 10 dias úteis no seu formato mais ágil, via pregão eletrônico.

- No dia 17/03, após desenho da quantidade de passagens e dos demais custos necessários à realização da Consulta pela Seppir, MDA, INCRA e FCP, a Seppir remeteu à coordenação do GT (AGU) o quadro de custos para que fossem partilhados com os demais órgãos que compõem o GT os gastos da Consulta. Até o presente momento não obtivemos manifestação desse apoio em relação aos custos.

- Como os órgãos que se apresentaram para contribuir com os gastos da Consulta (Seppir, MDA, FCP e INCRA) possuem restrições administrativas para a realização do evento em tão curto espaço de tempo, foi construída proposta alternativa de data.

- Tendo em vista, também, que em virtude do pouco tempo disponível para a realização da Consulta e entendendo que é fundamental haver um espaço que reúna as lideranças quilombolas de todo o país nesse debate, a Conaq apresentou que a melhor possibilidade, dadas as limitações existentes, seja a realização de um Seminário Nacional, com as 300 lideranças.

- A proposta final desenhada na reunião dialoga minimamente com a proposta apresentada pela Conaq, uma vez que de todos os pontos propostos sobrou apenas o Seminário Nacional. Por outro lado, dada a conjuntura atual e as possibilidades existentes, a proposta final, produto da reunião do dia 24/03, apresenta-se como a mais viável.

\section{- Proposta Alternativa:}

- até 28/03 - a Conaq enviará aos ministérios que estão custeando as passagens a lista com as 300 lideranças quilombolas de todo o país. Destacará dessa lista os 5 representes quilombolas (1 por região) que farão parte da equipe de sistematização dos resultados do Seminário Nacional. Será apresentada também, até o dia 28 pela Conaq, uma relação de 10 especialistas no tema que participarão da Consulta como facilitadores, debatedores ou palestrantes na dinâmica metodológica. De forma a viabilizar a construção da lista das lideranças e especialistas pela Conaq até o dia 28, os órgãos disponibilizaram a estrutura de Internet e telefone a 3 representantes da Conaq (dos quais Oriel já se encontra na cidade e outros dois virão até quarta para essa tarefa);

- 31/03 - Início do processo de solicitação e emissão das passagens;

- 15, 16 e 17/04 - Seminário Nacional de Consulta Pública à Nova Instrução Normativa do INCRA (local: Brasília / Participantes: 300 lideranças quilombolas, gestores públicos e especialistas); 
- 18, 19 e 20/04 - Período de sistematização dos resultados da Consulta. Participantes da equipe de sistematização: AGU, CC, Seppir, MDA, INCRA, FCP e 5 representações quilombolas (1 por região);

- 22/04 - Apresentação dos resultados finais provenientes da Consulta ao GT e às lideranças quilombolas. Apresentação da proposta da Nova Instrução Normativa ao gabinete do Presidente da República.

- Cientes da iminência do julgamento da ADIN pelo STF, e sabedores da importância da publicação da nova IN/INCRA no menor tempo possível, os representantes do governo presentes à reunião apresentaram a preocupação de disponibilizar à AGU a data alternativa para a Consulta (dadas as limitações administrativas) e buscar junto com esta outras possibilidades caso seja realmente inviável o adiamento, ora apresentado. Caberá à Seppir encaminhar à AGU a proposta alternativa de data e dialogar sobre a conjuntura, apoio à realização da Consulta (com a participação financeira de mais órgãos do GT) e finalizar o desenho final da Consulta.

- As limitações administrativas dos quatro órgãos que estão, até o momento, financiando a Consulta são muito definidas: 10 dias corridos para emissão de passagens e 10 dias úteis para licitação de espaço; Caso seja fundamental, portanto, antecipar a Consulta, o próprio GT precisará apresentar outras possibilidades.

\section{Encaminhamentos para essa semana:}

- O MDA analisará a viabilidade de emitir 2 passagens para quarta (26/03) para representantes da CONAQ atuarem na construção da lista das lideranças quilombolas. Estas duas pessoas ficarão presentes até o dia 28/3 em Brasília;

- Oriel (representante da CONAQ) já permanecerá em Brasília, e deverão ser encaminhadas as diárias para esses dias de sua permanência (de 25 a 28/3).

- A Seppir fará reunião interna com Ministro Edson Santos (Seppir) e Givânia Silva (Seppir) junto à equipe da casa presente na reunião do dia 24/03 para despacho sobre os seguintes pontos:

Apresentar as limitações dos órgãos para a realização de um Seminário num prazo tão curto;

Dialogar com a AGU sobre os prazos políticos e jurídicos para viabilizar a Consulta da nova IN;

Construir com a AGU outras possibilidades para readequação da divisão dos custos da Consulta. 


\section{ANEXO IV - COLETÂNEA DE PROPOSTAS PRODUZIDAS PELO GRUPO DE TRABALHO}

(6)

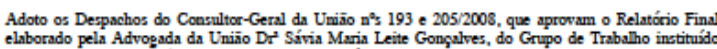

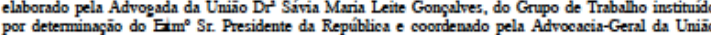
com o objetivo de identificar problemas o apresentar alternativas no que tange ì queestio quilombola indigens no Brasil.

2. Adoto, ainda, o Despacho do Consultor-Geral da Uniäo no 309/2008 que complementa os Despachos
nos 193 e $205 / 2008$.

3. Estou de acordo com as sugestóes formuladas pelos representantes das comuridades quilombolas ao

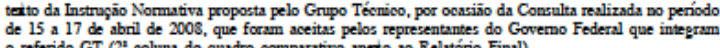

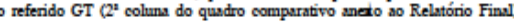

4. Penso não serem cabivivis as sugestôes nĩo acollidas pelo GT no procedimento de consulta ( $3^{3}$ coluns do quadro comparativo).

5. Assim, entendo que deve ser encuminhado ao Sr. Presidente da República o terto da N elaborado pelo Grupo de Trabalho que incorpora as sagestoes oferecidas pelas comumidades quilombolas e aco-

6. Necessária a submissio do novo teto ao Exmo Sr. Presidente, tendo em vista que S. Exa já havia

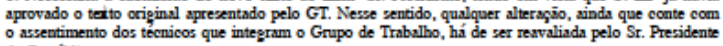
da República.

7. Estou de acordo com os mecanismos de divulgạnâ do trabalho do GT contidos nos itens 22 e 23 do Despscho no $193 / 2008$ - CGV

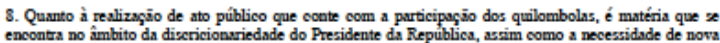
remināo com os Ministros de Estado cujes áress de atuagăio sejam afetas a materia, para deliberar sobre as sugestöes apresentadas pelas conumidades quilombo

9. Procedamn-se os registros nos assentamentos funcionais da Advogada da Unizo Ś́via Maria Leite 10. Determino sejam efetivados os encuminhamentos sugeridos nos itens 32,33 e 34 do mencionado Despacho, ao tempo em que registro a necessidade de esclarecimentos serem prestados aos Ministros do
Supremo Thibunal Federal e as Membros do Congresso Nacional sobre os objecivos da nova Instrugäio
Normativa do NCRA.

11. Após, determino o retono dos antos à Consultoria-Geral da Uniäo para as providêneiss descritas no
item 31 do Despacho $n^{\circ} 1932008$ - CGU.

12. Concluo reafinmando que o resultado do presente GT coordenado pela Adrocacia-Geral da Uniz̄o é uma inequivoca demonstragäo de que sempre é possivel o aprimoramento de marcos regulatónios com

13. No caso em question, chega-se ao final de uma importante etapa de trabalho que tem como objetivo

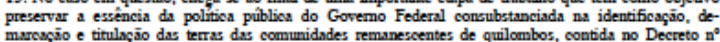

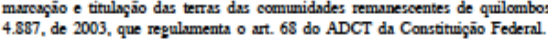

14. Destaco, por fim, importante avanço na efetivaçäo das diretrizes da Convengäo $n^{\circ} 169$, da OrFanizaçäo Intemacional do Trabalho - OrT, concistente na realizaçio da primeira consulta do Govemo a efetivagáo de seus direitos. Trata-se de momento histónico a ser elaltado.

$$
\begin{aligned}
& \text { Brasilia, } 22 \text { de agosto de } 2008 . \\
& \text { JOSÉ ANTONIO DIAS TOFFOLI } \\
& \text { Advogado-Geral da Uniäo } \\
& \text { ADVOCACLA-GERAL DA UNIÃO } \\
& \text { CONSULTORIA-GERAL DA UNIĀO }
\end{aligned}
$$

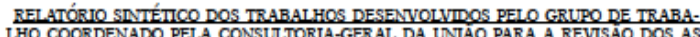
LHO COORDENADO PELA CONSLITORIA-GERAL DA UNIAO PARA A REVASAO DOS AS INADAS A INDIGENAS E QUTLOMBOLAS

ASPECTOS RETERENTES À QUESTÃO QUTLOMBOLLA

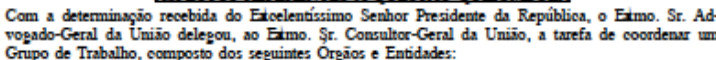

Advocosia-Geral, contando com integrantes da Consultorin-Geral da Uniāo - CGU, Procuradoria Geral da Uniäo - PGU (especialmenter representada pelo Departamento de Defesa do Patrimôtio da Uniżo-

\section{Presidência da República:}

Gabinete de Seguranga Institucional - GS

Secretaria Especial de Direitos Humanos - SEDH

Secretaria Especial de Políticas de Promogia da Igualdsde Racial - SEPPIR (especialmente representad

Soliticas Govemamentas - SAC

Subchefia de Asstuntos Juŕdicos - SAI

Ministério do Desenvolvimento Agrínio - MDA

Ministério da Justica - MJ

Ministerio do Meio Ambiente - MMA

Secretaria de Patrimânenio da Uniäo - SPU

Fumdagīo Cultural Palmases
Instituto Brasileiro do Mejo Ambiente e dos Recurgos Naturais Renovíveis - IBAMA

Instituto Chico Mendes de Conservagio da Biodiversidade
Instituto Nacional de Colonizagio e Reforma Agrán - INCRA
Instituto do Patrimánio Histónico e Artístico Nacional - IPHAN

Em 14 de setembro de 2007, houve o engajamento do Servigo Florestal Brasileiro, resultado de desmembramento administrativo do IBAMA.

A tarefa recebida pelo Grupo de Traballho foi a identificaşāo dos problemas etistentes, causadores de controvérsias administrativas entre Orgäos e Entidades da Administraçäo Federal, causadores de em-

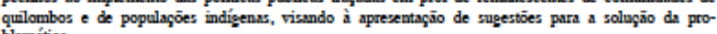

Após a abertara dos trabalhos em 25 de jullho de 2007, com a presidência do Erimo. Sr. Advogado-Geral da Uniäo, sob a coordensagio do Consultor-Geral da Uniäo, foi estabelecido o seguinte proceedimento teriam oportunidade de uma primeira manifesta̧ăio verbal, em reuniäo, trapando as linhss gerais dos pontos divergentes, mediante a separagaio dos dois temas quilombola e indigens e, posteriormente, todos

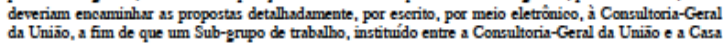
Civil (Subchefia de Analize e Acompunhamento de Políticas Governamentais - SAG e Subchefia de

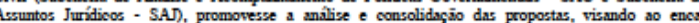
minhamento das soluģoes.

No dia 31 de julho de 2007, houve a primeira reuniāo aseroa da questio indigena.

Dando sequêencia ì elposigăo dos integrantes quanto à questäo quilombola, ocorreu a segunda reuniāo
em dia 2 de agosto de 2007 , quando forma conclúdss as abordanens gerais. Ficou estabelecido o prazo

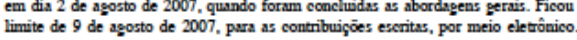

Prosseguiu a análise geral da questāo indigens em 7 de agosto de 2007, com o estabelecimento do prazo limite para as manifestaģos escritas, neste aspecto, em 14 de aposto de 2007.

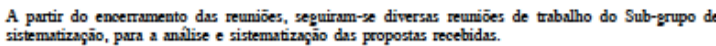

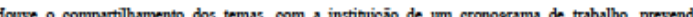
Houve o compartilhamento dos temas, com a instituigạa de umu cronograma de trabalho, prevendo quanto à questio indigena.

Questio Quilombols.

Do traballho do Sub-grupo, restou a conchusão quanto ì conveniênecia de elaborąạāo de diversos do-

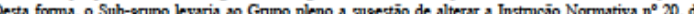
19 de setembro de 2007 , do NCRA, mediante nova redaçio que encamparia as sugestöes do conjumto, além da instituigăo de um docemento, que consolidaria todas as medidas gerenciais enumeradas pelo Sub-grupo de sintese, com fundamento das marifestasces dos participantes.

Encerrados os trabalhos preliminares do Sub-prupo de síntese, houve uma reumiāo em 10 de setembro de foram compartilhados com todo o conjunto, por meio eletrônico, ma mesma data:

1. quadro comparativo e sintétio de todss as manifestap̧ōes;

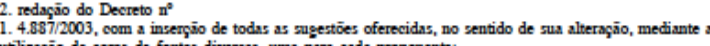
thizagäo de cores de fontes diversas, uma para cada proponente;

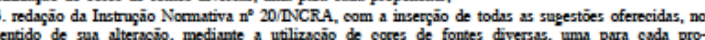
4. quandro comparativo entre a IN e o Decreto; e

5. quadro compurativo da $\mathrm{IN}$ com a Portaria no 14, 9 de janeiro de 1996, do Ministério da Justiga, que

6. quastro sintético das propostas de medidas perencisis

Houre, na mesma oportunidade designaşāo de uma reuriäo em 14 de setembro de 2007, interrepno durante o qual of participantes deveriam andisar a conclusio dos trabalhos do Sub-prupo, visando a

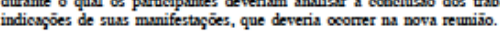

Realizada a primeira remiāo de consolidaçāo final, fez-se neceessário o prosseguimento dos trabalhos por te

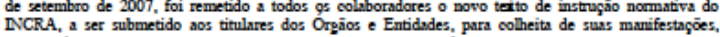
visando à efetiva conclusão dos trabalhos do grupo, no toosnte à questäo quilombola.

0 mesmo procedimento de traballho foi adotado quanto ì questio indigena.

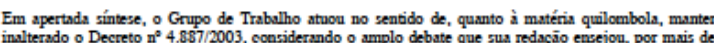
dois anos, junto à Casa Civil, bem assim a refleảio de que seu conteúdo, embora objeto de inpuganagăo Federal.

Desta forma, a alteragāo da Instruçäo Normativa do NNCRA, mantendo a íntegra dos nortes estabelecidos

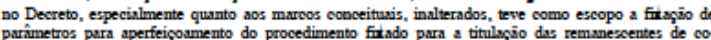

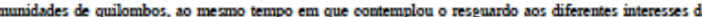
Estado que guasdam interface com a etecugio da política pública em relevo, cabendo referix que dizen

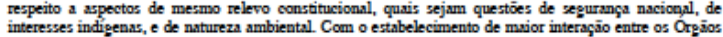
e Entidades, que passario a atuar cogjuntamente, ficam redurids as possibilidades de conflitos adinistrativos obstasem a implementaçấ das politicas publicas.

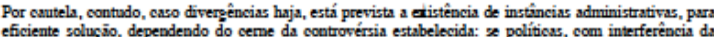
Casa Civil; $x$ jurídisa, por attuaģio da Adrocacia-Geral da Uniẫo. 
No espectro de aperfeiçomento do procedimento para a titulap̧io quilombola, merece especial referéncis

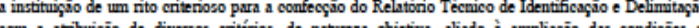
com a atribuigăo de diversos critérios, de natureza objetiva, aliado à amplisgáo das condigóes de

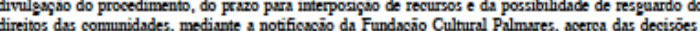
direitos das coms proferidas.

Antreipando-se, a Fundagio Culaural Palmases providenciou a revisaio do ato nomativo que regula o procedimento de certificaģâ das comunidades usto-identificadas e publicou a Portaria no 98 , de 26 de novembro de 2007 .

A conclusaio da parte téenisa dos trabalhos do Grupo, quanto ì questiōo quilombola já untecipou a clara possibilidade de solugiono do problema trazido ao Grupo.

Em 24 de setembro de 2007, das 14 boras is 20 horas e 40 minutos, o Eamo. Sr. Consultor-Geral de

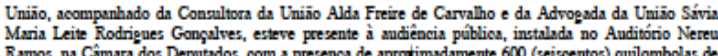

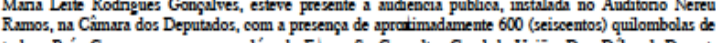
todo o País. Compuseram a mesa, além do Ermo. Sr. Concultor-Geral da Uniäo: Dra. Deborah Duprat,

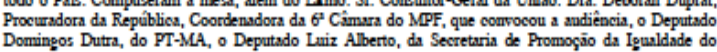
Estado da Bahis, $\circ$ Dr. Rolf Hackbart, Presidente do INCRA, $\circ$ Dr. Zulú Arájo, Presidente da Fundagāo Cultural Palmases, a Dra. Givamia Silva, da Secretaria Especial de Políticas de Promoçāo da I I

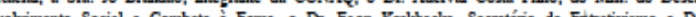
volvimento Social e Combate in Fonxs, o Dr. Egon Kralcheclas, Secretánio de Ertrativirmo e D senvolvimento Rural Surtentán
do Deseavolvimento Agráio.

Adotot-se como procedimento de trabalho a menifertacaio preliminar dos interantes do Movimento Quilombola, para pergumtas dirigidas acs componentes da mesa. Houve longa fila para o uso da palarra, de maneira que, exceto por alguns esolarecimentos, preliminsres da mesa, a palavra esteve franqueada,
por ordem de inserigaio, pura os quilombolas, do inscio dos traballhos, até as 18 horas e 40 minutos.

Os Qullombolas insurgiram-se de forma veemente coutra a proposigāo, pelo Deputado Valdir Colatto, do PSDB-SC, do Projeto de Decreto Legislativo n 044/2007, com o objetivo de promover a suspensảo do

Em síntese, o Presidente da FCP esclareceu que a alteraçäo da Portaria regente da certificaşäo quanto auto-atribuigăo decorreu, especialmente de recomendsyjuo do Ministerio Publico Federal, no Estado da as emissaio de certidio de auto-atnibrigion. Naquela oportunidade, a Portaria estava pronta para publicaçio, pendendo apenas da revisino de terto.

Os Representantes Quilombols manifestaram sobre a necessidade de uma posigio uniforme por purte do MPF quanto as trato de suas questioes.

Houve uma observagio, por parte dos integrantes do Movimento Quilombola, no sentido de que se consideram descendentes de afficsnos, e naño de egcravos.

Foram divulgados, pelo Morimento Quilombola dois movimentos ativistas, previstos pura 5 de outubro, denominados 'A gente nāo $s e$ vê por aqui', como protesto à matéria antes referida, e em 8 de novembro, encetando uma luta pela terra.

A Dra. Déborah destacou que a AGU havis estabelecido o entrendimento quasto à apliosyio da Convençio OIr $\mathrm{n}^{\circ} 169$ e que o Eimo. Sr. Ministro Toffoli, quando ocupando cargo junto à Casa Civil,

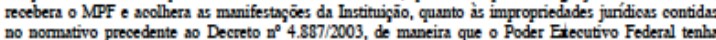

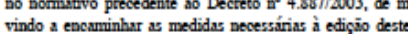

A Dra. Givania e o Dr. Zulu, confirmando haver participado de reunioes do Grupo de Trabalho coordenado pela AGU, ratificaram a manifestagano do Eimo. Sr. Consultor-Geral da Uniäo, quanto as esforgo despendido, no sentido de que os trabalhos $s e$ encaminhem visando à eliminaşäo dos entraves questio quilombola.

O Dr. Zulu observou que a AGU seria uma aliada. O Dr. Rolf, nada obstante nāo tenha participado do Grupo de Trabulho, declarou estar informado de seus encinimhamentos e de acordo com as sua

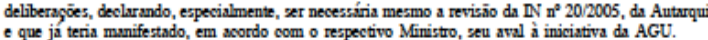

A Dra. Renata Leite, do Min. do Des. Agránio, propôs que o Movimento agendasse uma reuniäo com o respectivo Ministro, sugerindo a elaboraģio de una pauta preliminar.

A Sra. Jô Brandāo solicitou que a consulta pública quanto à alteraģio da $\mathbb{N}$ fosse encaminhada a todos os estado:

A Dra. Déborah propôs que o Movimento Quilombola pleitessse uma audiência com $\circ$ Ministro Cezs Peluso, Relator da ADIn $\mathrm{n}^{\circ} 3.239$, ajuizada em face do Decreto $\mathrm{n}^{\circ} 4.887 / 2003$.

Em 25 de setembro, bouve o encominhamento de mensagem electônica, a todos os integrantes do Grupo titulares das pastas respectivas até is 18 horas de 27 de setembro de 2007.

Apresentaram masufestaçecs, em reeposta: Ministerio da Justica, Fundaçio Culhural Palmares, Ministen do Meio Ambiente, BBAMA, Inst. Chico Mendes, Servico Flocestal Brasileiro, Gabinete de Seguranga

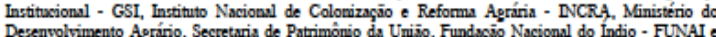
Secretaria Especial de Política de Promoģao da Igualdade Rasial - SEPPIR.

O Sub-grupo de síntese, reurido em 4 de outubro de 2007, apreciou cada uma das manifesta̧̧öos de

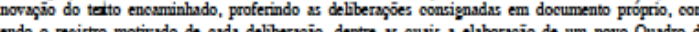
tendo o registro motivado de cosda deliberasiono, dentre as quais a elaboraçaio de um novo Quadro de Grupo.

Ao entender conclúda esta fase dos trabulhos, relativamente à questio quilombola, o Ermo. Sr. Corsultor-Geral da Uniaio determinou a colegaio de todos os documentos relacionados, pura submissio a Exmo. Sr. Advogado-Geral da Uniaso.
São instrumentos de traballbo constantes desta autuaşāo: (1) encadernaşão com o conjunto das propostav remetidas pelos Orgäas e Entidades, quanto à questäo quilombola; (2) cópias pegas judiciais sobre

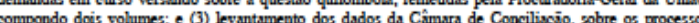
em andamento tendo como tems as questöes indigenss e quilombolas.

Para prosseguimento dos trabullhos, no tocante ì questio indigena, foi convocsdo o Sub-grupo de síntese para uma reuniäo em 9 de outubro de 2007 , is 9 horas.

Considerando o encerramento dos trabalhos do Grupo, quanto à apreciaşāo téenica da questäo quilombola, em 9 de outubro de 2007, o Subgrnupo de sintese se reeuniu, pela manhä e i tarde, chepgando at

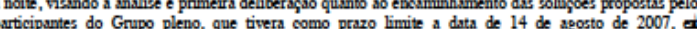

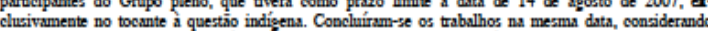
que nino pairvama quanto a este último tema o mesmo teor de controvérsias configurado relativamente
ì primeira questio. Partindo das premissas eleitas para o primeiro tema, deliberou-se pela não alteraçāo do Decreto $\mathrm{n}^{\circ} 1.775$, de 8 de janeiro de 1996. Alem de objetivar elidir o surgimento de questionsmentos judicisis, nio se

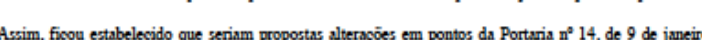
de 1996, do Ministério da Justiga, doecumento em que ficariam contempladas as sugestiós que naso impliossem medidas meramente gereaciais. 0 outro documento, entio seria composto pelas medidas
referentes a procedimentos administrativos.

Inicialmente, foram elaborados os seguintes documentos:

1. quadro comparativo de todss as propostas;

2. quadro comparativo de todas as propostas, com a apreciaşio de cada:

3. novo terto da Portania do Ministerio da Jutbiga; e

4. quadro de medidas gereaciais.

De 9 a 11 de outubro de 2007, os integrantes do Subgrupo de síntese tiveram prazo para revisio do

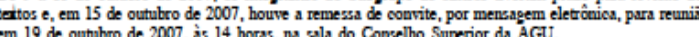

Para os convidados, bouve $O$ envio dos seguintes documentos, para analise preliminar: quadro comparativo de todas as propostas, novo terto da Portaria do Ministerio da Justiga e quastro de medidas gerenciais.

A reuniäo, com registro ema ata, consistiu na apresentaģäo, pelo Ermo. Sr. Consultor-Geral da Uniäo, dav Jeliberagojes do Subgrupo de sintese, devidamente fundamentadas nos argumentos previanente corcignados, momentio em qux houve oportunidade para manifestepano dos integrantes do Grupo pleno sobre cada ponto, com o estabelecimento de consenzo sobre cadda aspecto, como condigio para avaryo a cuttros do IBAMA, ofereceun um documento durante a reumisio, recebido pelo Ermo. Sr. Consultor-Geral, para fazer constar do processo administrativo respectivo.

Na mesma data, o destacsdo documento do Instituto Chico Mendes, após digitalizado, foi encuminhado

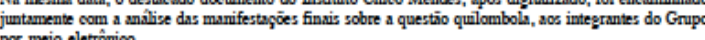
or meio eletrônion.

Em 23 de outubro de 2007, com a aglutinasāo do pronumeiamento do Instituto Chico Mendes e consequente andilise, houre encosminhamento a todos os partcipantes do Grupo de Traballho dos do-

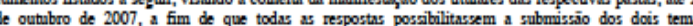
(quilombola e indigena) ao crivo de uma reuniäo ninisterial agendada para 25 de outubro de 2007.

Receberam os participantes, por mensagem eletronica:

atta da reunitio de 19 de outubro de $200 \%$ :

quadro comparativo das propostas dos Orgäos e Entidades;

4. novo terto pera a Portaria do Ministério da Justica;

5. listagem com os nomes completos, números de telefone e enderegros eletrônicos de todos os purticipantes do Grupo de Trabalho.

Desta forma, restou encerrada a parte técnica do traballo de conciliaçāo interinstitacional referente is abordagens administrativas quanto is questöes controvertidas no tocante it implementaģäo des políticas indigens:

Em 6 de novembro de 2007, o Ermo. Sr. Advogado-Geral da Unizio e o Ermo. Sr. Consultor-Geral ds Uniaio, em reumiäo no Palácio do Planalto, apresentaram ao Eicelentíssimo Senhor Presidente da República e aos Ermos. Srs. Ministros da Casa Civil, Justiga, Defesa, Desenvolvimento Agrínio, Meio

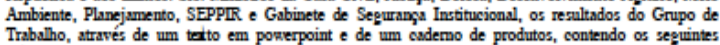
Traballh:

QUESTÃO QUILOMBOLA

Nowo tento pusa Instrugio Normativa no 20, de 19 de setembro de 2005, do Inctituto Nacioanal de Colonizagajo e Reforma Agríia - INCRA

Propostas Gerenciais oferecids

Quadro Comparativo enter o Decreto no 4.833/2003, Instrugāo Normativa n 20/2005-DNCRA e novo

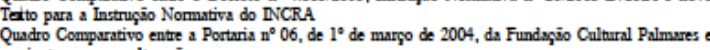
a minuta para sag alteraģa

Novo teato para a Portania no 14, 9 de janeiro de 1996, do Ministério da Justica

As antoridades indicadas aprovaram os resultados do Grupo de Trabalho, com algumas ressalvas

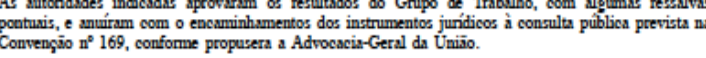

De imediato, as alteragóes apresentadas foram efetivadas. Por uma questio metodológica, o Ermo. Sr.

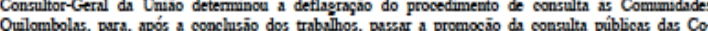
Q enha providencisdo, de ordem do Ermo. Sr. Consultor-Geral da Uniäo, o encennimhamento, por mensagem eletrônica constantes nestes autos, dos documentos referentes a este pública para a sua Coordenaşão nacional 


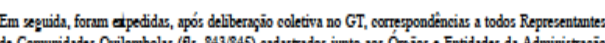

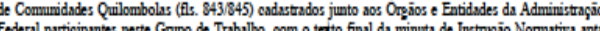
Federal purticipuntes netste Grupo de Trabalbo, com o

E Emmo. Sr. Consultor-Geral dirigin o Oficio n n $^{\circ} 355 / 2007-C G U / A G U$, de 30 de novembro de 2007, Eama. Sra. Coordensdora da $6^{2}$ Cimusa do Ministério Público Federal (fle. 846/848), Dra. Deboral Duprat comumioundo as providencis abordadas no puriganafo preecedents, na oportanidade em que convidou pura as reuniöes entio previrtas.

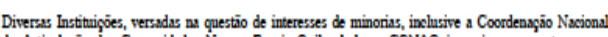

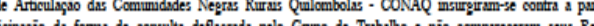

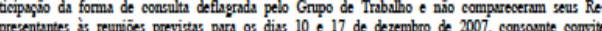

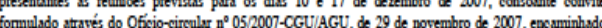

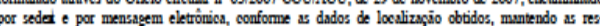
pectivas comprovacoues nos atos.

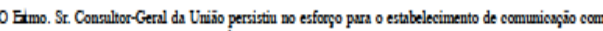
- Morimento Quilombola, em decorrencia do que restou designada nova reumia com os seus it tegrantes, em 19 de dezembro de 2007, no auditónio da Escola da AGU, cujos regirtos reepectivos constam de ata nos antor.

Indieppenável observar a preesnąa da Eama. Sra Subprocuradora-Geral da repúbica, Dra. Deborah Duprat na reuniso, oportunidade em que observou que oprocedimento de Consulta Pública insugurrado

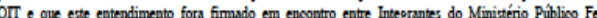
deral.

A CONAQ obsere de Coordensyio do Grupo de Trabulho em relevo, na mencionada remijo, o prazo

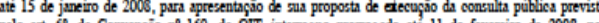

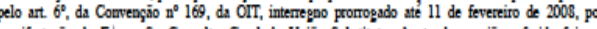

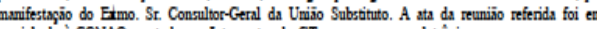

Em 15 de fevererio de 2008, a Coordenangio Nacional de Articulagäio das Comminidades Negras Rurnis QUTLOMBOLA PARA O PROCESSO DE CONSTITA SOBRE ALTERACOES NA NN 20" - AL 1.1221 .127

O documento sugere os seguinte procedinento de Consulta Pública, embora ressalve que os seus detalhes

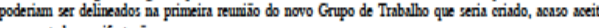
a comentada marifestagio

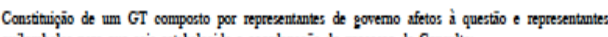
quilombolas para ques sgja estabelecida a coordensyo do processo de Consulta.

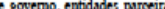

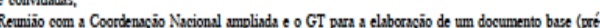
proposta):

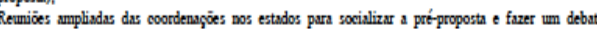

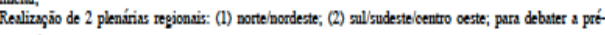

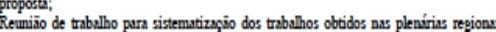

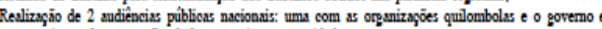
outra mais ampla com quilombolas, parceiros e comridedos.

Attendendo determinaşo do Elemo. Sr. Consultor-Geral, todos os Inteprantes do atual Grupo de Tra-

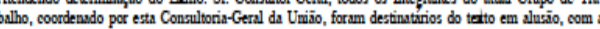

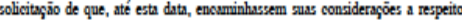

O documento apresentado pela CONAQ (t. 1.1.28) foi submetido ì avalisgaio de todos os Integrantes do

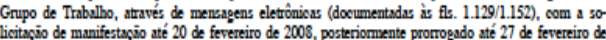

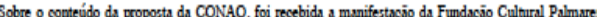
através de san Diretoria de Proteq̧io do Patrimânio Afro-Brasileiro, com o seguinte conteúdo:

Consideraģoes referentes a Pré-Proposta do Movimento Quilombola para o Proceesso de Consulta sobre

Alteraghoes na IN 20: Rurais Quilombolss- CONAQ apresentada i Adrocacia Geral de Unizio-AGV, porém estamos preocupvosos em relagio ass gastos provenientes das demandas. Sugerimos que tenhamos uma convers previa com representantes da CONAQ e os órgios diretanzente eavolvidos na questio, para que posAtenciosmentente,

Maria Bemadete Lopes da Siva

Diretor

Diante do descrito panorama, o Ermo. Sr. Consultor-Geral da Uniiio convocou reuriäo do GT, em 14 de masço de 2008, para deliberagio coletiva quanto a propotata ofereseida pela CONAQ. Na oportumidade, a SEPPR, representada pela Dra. Givania Silva, apresentou un nevo modelo de consulta publica,

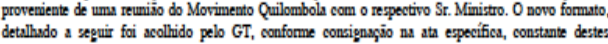

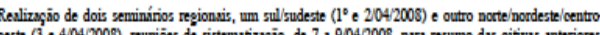

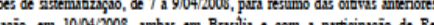

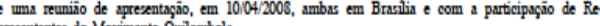
presentantes do Movimento Quilombols.

Seguindo as deliberagáes, a SEPPR, o MDA o o NVCRA promoveram reunizio com o Movimemt

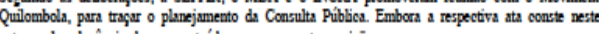
autos, pela releréancia de seu conteudo, segue a sua transerịga:
Memónia de Remiäo Preparatócia para a Conculta à nova DNINCRA

Data: 24 de marşo de 2008

Local: Sala de Reuriöes da Seppir
Hocínio: 17 is 19 h30

Participuntes:

Oriel Rodigutes - ConaquSP

Ronaldo dos Santos - Consq IV

Jhonny Martins - Consq MS

Benadett Lopes - FA

Reasta Late - MDA

Rui Lesndro - Ine

Sandra Cabral - Seppir

Giovanni Harvey - Seppir

Barbara Souza - Seppr
Objetivo da Reunitio:

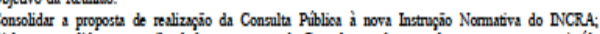
Dialogar com lideramas quilombolas a proposta da Consulta, tendo como base a proposta costatinúds

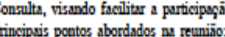

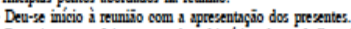

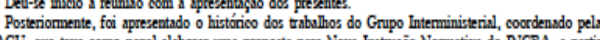
AGV, que teve como papel elabora uma proposta para Nova Intrugya Nomativa do DNCRA, a partir

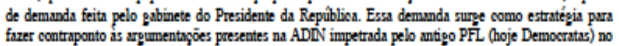

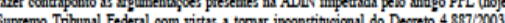

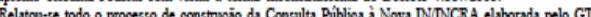
cujos marcos sao:

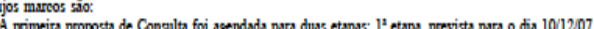

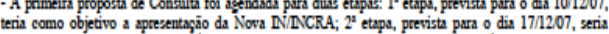
voltada pura a diveussio do conterúdo com as representasoes quilombolas de todo pús para finalizar uma proposta ímica so tetto da nova NNNCRA;

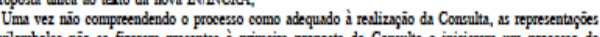
qulombolas nio se fizeram presentes i primeira proposta de Consulta e imciaram um processo de

- No dia 19/12, em reminio de curititr informal entre alaumas lideramas qulombolss e parte dos mimintenos que compoem o GI, Gcou decedido qux a CONAQ exsaminhana proposta de conculta pras de prazo, entregundo a versio final de sua proposta i AGU bo dia 15.0208 . O processo de manifestapoes por purte dos diversos órgios que compöem o GT e a construgăo de ums proposta por parte do Goremo, em diálogo com o colocosdo pela Coang, foi finalizado coma a presente

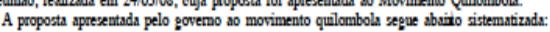

\begin{tabular}{|c|c|c|c|}
\hline \multicolumn{4}{|c|}{ 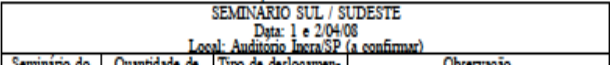 } \\
\hline $\begin{array}{l}\text { Semininio do } \\
\text { Sull Sudetete }\end{array}$ & $\begin{array}{l}\text { Quntidade de } \\
\text { pasticipumber }\end{array}$ & $\begin{array}{c}\text { Tipo de deslocamen- } \\
\text { to }\end{array}$ & Observąăo \\
\hline & 100 pessous & Á́reo e Tentestre & \\
\hline MG & 25 & Aéreo e Terrestre & 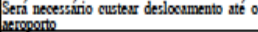 \\
\hline$S P$ & 25 & Temestre & \\
\hline ES & $\frac{10}{10}$ & 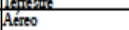 & Serán necessario curterr deslosumento att o \\
\hline RS & 15 & Aéreo & 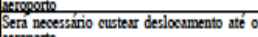 \\
\hline SC & 05 & Aéreo & Serán neceessário curterr deslocumento at'e o \\
\hline PR & 10 & Aéreo e Terrestre & 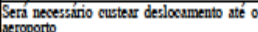 \\
\hline
\end{tabular}

\begin{tabular}{|c|c|c|c|}
\hline \multicolumn{4}{|c|}{$\begin{array}{l}\text { SEMINARTO NORTE / NORDESTE / CENTRO OESTE } \\
\text { Data: } 3 \text { e 40408 } \\
\text { Local- CNII (a confinmar) }\end{array}$} \\
\hline $\begin{array}{l}\text { Seminánio Nor- } \\
\text { te Nordes: } \\
\text { to Centro- }\end{array}$ & $\begin{array}{l}\text { Quantidade de par- } \\
\text { ticipuntes }\end{array}$ & \begin{tabular}{|l} 
Tipo de detloos- \\
mento
\end{tabular} & Observagio \\
\hline Extador & 215 pesposs & Áreos Terrestre & \\
\hline $\mathrm{PA}$ & 25 & Aéreo & $\begin{array}{l}\text { Será necessíio custear deslocamento até } 0 \\
\text { nercopoto }\end{array}$ \\
\hline MA & 25 & Á́reo & $\begin{array}{l}\text { Será necessínio custear deslocameato atté } 0 \\
\text { geroporto }\end{array}$ \\
\hline$B A$ & 25 & Tenrestre e Á́reo & $\begin{array}{l}\text { Será necessííio custar deslocemento atté o } \\
\text { sercoporto }\end{array}$ \\
\hline RO & 06 & Áéreo & $\begin{array}{l}\text { Será necessíio custers deslocemento at'́ } \\
\text { seroporto }\end{array}$ \\
\hline $\mathrm{RN}$ & 10 & Aleteo & Serra necessinio custar deslocemento atti 0 \\
\hline MS & 10 & Átroo & 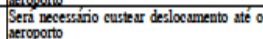 \\
\hline Go & 09 & Aléreo & $\begin{array}{l}\text { Sera necessínio curters deslocamento atte } \\
\text { gercoporto }\end{array}$ \\
\hline PI & 15 & Aléreo & 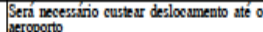 \\
\hline CE & 09 & Alereo & Serai necessitio curtar deslocemento ati o \\
\hline AL & 10 & Aéreo & Serera necessíio custear deslocemento atte o \\
\hline TO & 06 & Aléreo & $\begin{array}{l}\text { Sera necessíio custear deslocemento at'́ } 0 \\
\text { serpoonto }\end{array}$ \\
\hline PB & 10 & Alereo & Será necessifio custers deslocumento atte 0 \\
\hline SE & 10 & Alereo & 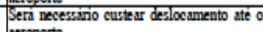 \\
\hline PE & 20 & Aéreo & Sera necessínio custear deslocemento atte o \\
\hline AP & 10 & Aéreo & Serra necessíio custers deslocamento at'́ o \\
\hline MT & 15 & Aéreo & 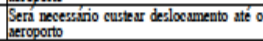 \\
\hline
\end{tabular}


- Após a apresentapio da proposta pelos representantes do Govemo presentes à reuniäo, iniciou-se debate sobre a viabilidade administrativa de realizar um eveato desse porte, tendo em vista as etigêncis administrativas para emissaio de passagens e locagio de espaso que demendam tempos superiores is
datas previstas. datas previstas.

A emissaio de passagens, por clemplo, pressupoé um processo de no mínimo 10 diss corridos nos

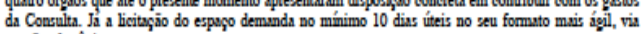
pregio electronioo. da Consulta pela Seppir, MDA, NCCRA e FCP, a Seppir remeter a coordenapio do GT (AGU) o quadro de custos para que fossem purtilhados com os demasis órpios quex compóem o GT os gastos da Consulta

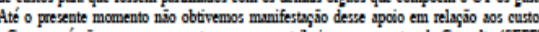
- Como os órgáos que es apreesentaram para contrburir com os gastos da Consulas (SEPPIR, MDA, FCP - NCRA) possuem restriģes administrativas para a realizaģo do evento em tío curto espaso de tempo foi construida proposta altemativa de data.

- Tendo em vista, também, que em virtude do pouco tempo disponível para a realizaşio da Consulta e entendendo que ef fumdanental haver um esposo que reuma as lideraras quilombolas de todo o pui reslizapio de un Seminisio Nacional, com as 300 liderangas.

A proposta final desenhada na reminito dialoga minimansente com a proposta apresentada pela Conaq, uma vez que de todos os poatos propostos sobrou apenss o Seminírio Nacional. Por outro lado, dada conjuntura atual e as possiblididades existrates, a proposta final, produto da reumino do dia 24.03, apresenta-se como a mais vível

Proposta Alternativ

atte 28,03 - a Conaq envisrá aos ministérios que estio euteando as passagens a lista com as 300 lideranças quilombolas de todo o pais. Destacará dessa lista os 5 representes quilombols (1 por regiaio) que faraio parte da equipe de sistematizacio dos resultados do Seminírio Nacional. Será apresentad

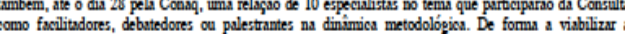

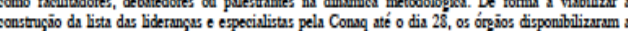
estruara de Intemete telefone a 3 reperesentantes da Conaq (dos quass Oriel já se encoontra na eidade e outros dois virio at'́ quarta para essa tasefa);

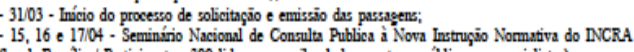
Clocel: Braslia / Puticipuntes: 300 bideraysas quilombolss, gestores públicos ce especialistass); 18, 19 e 20.04 - Penodo de sistematizasio dos resultados da Consulta. Participantes da equipe de qiio):

-2204 - Apresentapio dos resultados finas proverientes da Consulta ao GT e is lideramas quir

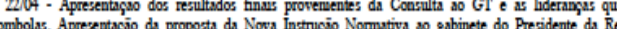
públice.

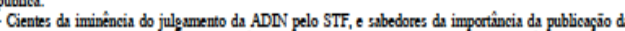
pova ININCRA no menor tempo possivel, os sepresentantes do govemo presentes ì reumiäo apre-

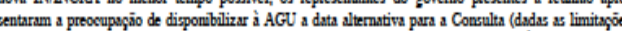
administrativas) e buecar jumto com esta outras possibilidades caso seja reelmente invível o adiemento, ora spresentado. Caberá í SEPPIR encaminhar a AGU a proposta alternativa de data e dislogur sobre conjuntara, apoio ì realizsagio da Consulta (com a purticipopgio financeira de masis órgios do GT)

- As linitap̧óes administrativas dos quatro ócrgios que ettio, até o momento, financiando a Consulta saio minto definidas: 10 dias corridos para emissio de passagens e 10 dias úteis pura licitagio de esporso

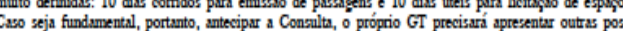
sabilidades.

Enouninhsmentos para esa seman

- OMDA andisurá a viabilidade de emitir 2 passagens para quasta (2603) para repreesentantes de CONAQ aturem na constugáo da lista das biderangas quilombolss. Estas daus pessoss ficario presentes até o dis $28 / 3 \mathrm{em}$ Brasil

- Oriel (representante da CONAQ) já permanecerí em Brasalia, e deverio ser exomminhadss as dísiss para esses dias de gua pemanéncia (de 25 a 2833).

Edron Samtos (SEPPIR) e Givinin Silva (SEPPIR) junto Thio do dia 2403 pura despacho sobre os seguintes pontos:

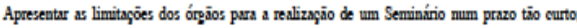
Dislogar com a AGU sobre os prazos politicos e juŕdicos pura viabilizar a Consulta da nova $\mathrm{N}$; Construir com a AGU outras possibilidedes para readequagio da divisio dos custos da Consulta. Nova reuniio do GT foi coarocada para 27 de maryo de 2008, com o objetivo de avalingio dos resultados da reumiäo de 24 de marfo de 2008, conviderando uma alteraģio de cronograma e a preménecin do tempo, ja descrita em diversos documentos, devido a conclusio dos atbos da ADl $n^{2} 3.239$ ao En báxicas da Consulta Pública, sendo relevante descrever o foco nos seguintes appectos:

Pressuposto do novo teato da Intruyaio Normativa, como documento base, artigo por artigo, coove templando o quadro compurativo do Decreto e os tetos da $\mathrm{N}$, vipente e o proposto pelo $\mathrm{GT}$, prevendo se 30 minutos, em média, pasa cada dispositivo;

Prevalencia de foco deve ser o debate do teato, sem digressão em palestras, devido à premênecia do tempo;

Considerando que sia tres dias de reuriöes, com oito horas dárias e um total de 24 hors, estas deveem

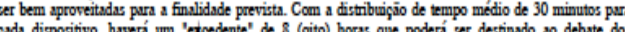
dispositios masis poléricoses

Previsaio de tres hipóteres de resultados para a consulta púbicer (1) manutengion dos dispositivos, (2) alteragio total ou parcial dos disposituros, quando se formar coneenso GT - Movimento Quilombola (3) apresentagio das manifestagoes do Movimento Quilombola nio admitids pelo GT;

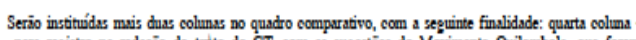
para registro na redagajo do terto do GT, com as sugettóes do Movimento Quilombola, qux foren: a do servasues, sugesties, plestos do

Os trabulhos serio encaminhados na sequiência leitura dos dispositivos, com o oferecimento, na forma de

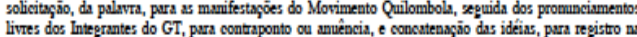

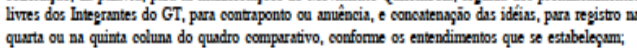

Na medida do possivel, solicitar sos representantes das Comuridades que jí tragem para a convults

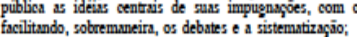

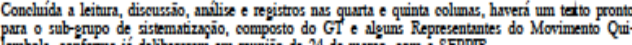

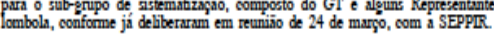

Finalmente, visando ao desenho da metodologia de trabulho a ser deservolvida para a efietivagäio da abril de 2008, no additónio da Evocla da AGU, encontro dividido em duas pastes: uma intema, com os

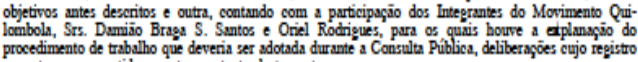
procedimento de trabalho que devenat ser adotada dura

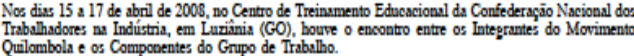
As despesas deconentes dos deslocamentos e estada dos Interrantes do Movimento Quilombola foram

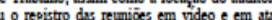

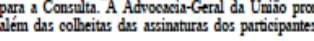

0 Morimento Quilombola obteve o deferimento de participaçio de doze expecialistss, para o seu

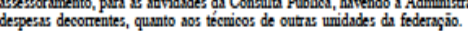

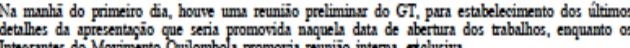

$\mathrm{Na}$ inasuguragio dos traballhos, foi distrabuílo a todos os participantes da Consulta Pública o seguinte material. (1) zato, contendo a redagio do ant. 68, da Constituipio Federal e o Decerto $n^{\circ} 5.051$, de

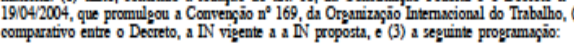

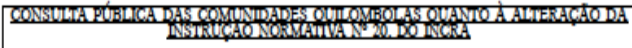

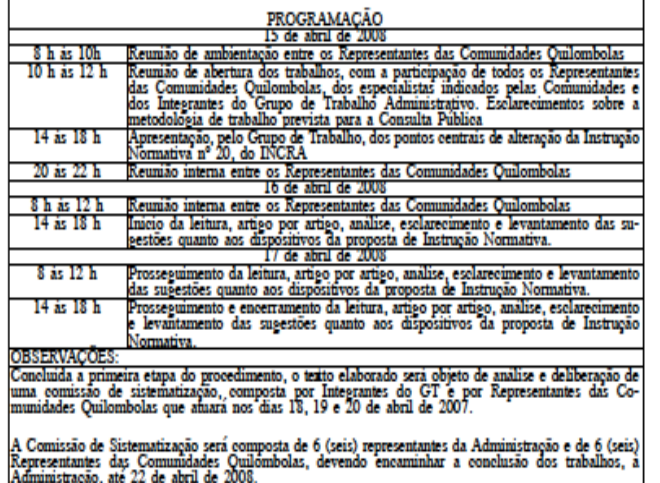
Quando compareceram os Componentes do GT para os trabalhos da tarde de 16 de abril de 2008 , os
Integrantes do Movimento Quilombola solicitaram uma alteragio de cronograma, pura permanecerem em

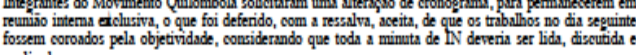
unalisada.

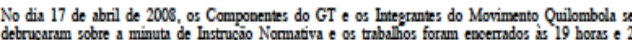
minutos, coma confoçäio de um quadro compratatio de três colunas, contendo: (1) a minuta do GT, (2)

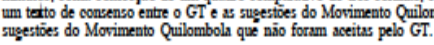

Ficou definido que uma Conissio de Sistematizagio partínia, com doze integramtes, desde logo indicados, faria, no período de 5 a 7 de abril de 2006 , a revisio e adequagaio do terto da columa

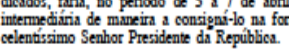

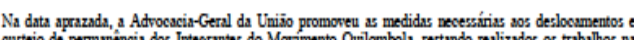

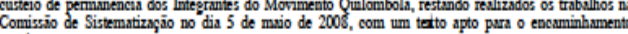
previsto.

Extäi juntadas aos autos do proceesso administrativo todas as correspondênciss resectidas pela AdvocaciTodas as reumiöes realizads desde 25 de jultho de 2007 estio registradx em atas, constantes destes

\section{São anectos deste Relatácio:}

- Quadro comparativo entre ot teito do GT, o teato de conrenso entre o Movimento Quilombola e o GI - o terto edclurivo do Movimento Quilombola, cujo conteúdo naio propiciou o estabelecinento de

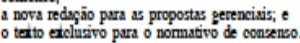

Brasilia, 6 de mixio de 2003.

SÁVIA MARLA LETIE RODRIGUES CONÇALVES Ategramte do Grupo de Trabulho 
RESUMO DAS MEDDAS GERENCIAIS PROPOSTAS QUANTO À QUESTÄO QUTLOMBOLA

VERSÃO DE 1310822008

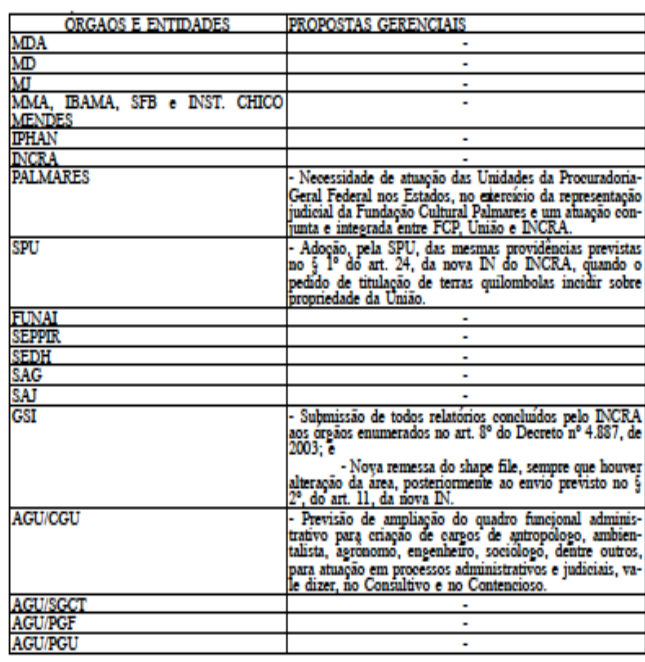

NSTRUÇĀOA NORMATIVA No

DE _ DE 2008

Regulamenta o procedimento pura identificap̧äo, reconhecimento, delimitaģo,

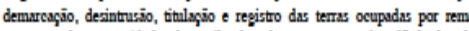
nescentes das conunidades dos quilombos de que tratam 0 Art. 68 do Ato $d$ Dipposiçoes Constitucionsis Transitónis da Constitugiaio Federal de 1988 e 0 Decreto $\mathrm{n}^{\circ} 4.887$, de 20 de novembro de 2003.

O PRESTDENTE DO NSTTIUTO NACIONAL DE COLONIZAÇĀO E REFORMA AGRÁ. RIA, no uso das atribuighees que lhe conferem 0 art. 20, inciso VII, do Anero I, do Decreto no 5.735 , de 27 de marşo de 2006, e art. 110, inciso IX, do Regimento Intemo de Autarguin, aprovado pela Portari $\mathrm{n}^{0} 69$, de 19 de outubro de 2006, do Ministro de Estado do Desanvolvimento Agrírio, e tendo em viste

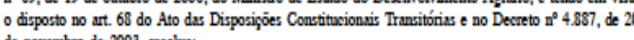
de novembro de 2003, resolve:

\section{OBJETIVO 1}

Art. $1^{\circ}$. Estabelecer procedinentos do processo sdministrativo para identifiospäio, reconke-

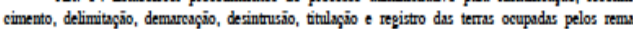
nescentes de commuidades dos quilombos.

\section{FUNDAMENTAÇÄO LEGAL}

Art. $2^{\circ}$. As ạöes objeto da presents Intrungio Normativa têm como fundamento legal

I - art 68 do Ato das Disposiģoes Constitucionais Transitónis da Constinigäio Federal;

II - art. 215 e $216 \mathrm{da}$ Constituigio Federal;

III - Lei $x^{\circ} 4.132$, de 10 de setrembro de 1962;

NV - Lei no 9.784 , de 29 de juneiro de 1999;

- Lein ne 4504 , de 30 de novembro de 1964;

VI - Decertot $\mathrm{n}^{\circ} 59.428$, de 27 de outabro de 1966

VII - Deereto $\mathrm{n}^{\circ} 433$, de 24 de juseiro de 1992 ;

TX- Medida. Provivónia no 2.183-56, de 24 de aporto de 2001;

XX- Medda Provisona $n^{\circ} 2.183-56$, de 24 de

$X$ - Lei $n^{\circ} 10.267$, de 28 de agosto de 2001;

- Decreto a 4.087, de 20 de aovembro de 2005,

indigenas e tribasis, promulgada pelo Decreto no 5.051 , de 19 de abril de 2004:

XIII - Lei $\mathrm{n}^{\circ} 10.678$, de 23 de mixo de 2003.

XTV - Decreto $\mathrm{n}^{\circ} 6.040$, de 7 de fevereiro de 2007

XV-Canvençio sobre Biodiversidade Biológica, promulgada pelo Decreto no 2.519, de 16 de maşo de 1998.

\section{CONCEITUAÇOEES}

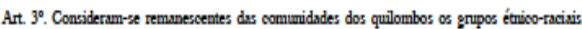

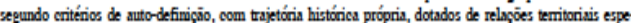

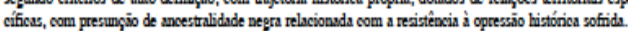

Art. $4^{\circ}$. Consideram-se terras ocupsdas por remanescentes das conmuidades de quilombos tods

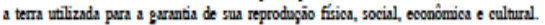

COMPETÉNCLA

Art. 5". Compete ao Instatuto Nacional de Colonizagăo e Reforma Agrána - DNCRA a ider-

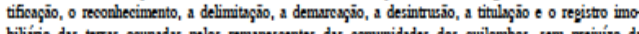
bilísino das terras ocupadas pelos remanescentes das comunidades dos quilombos, sem prejuízo de competência commm e consorrente dos Estados, do Distrito Federal e dos Mamicípios.
CERTIFICAÇĀOO

Art. $6^{\circ}$. A suracteriząajo dos remanescentes des comumidades de quilombos será atestada eediante auto-definicio da comunides.

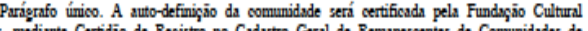

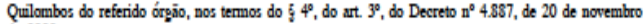

PROCEDMENTOS ADMDISTRATIVOS PARA ABERTURA DO PROCESSO

Art. 75.0 proseesso administrativo terá imicio por requerimento de qualquer interessado, das entidsdes ou associsyces reprexentatives de quilombolas ou de oficio pelo NiCRA, sendo entendido

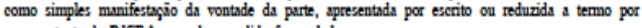

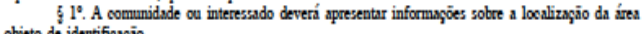

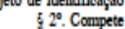

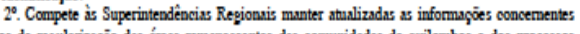
aos pedidos de regulanizagio das áreas remanesentes das comuridades de quilombos e dos processos em curso no Sistema de Obtengio de Terra - SISOTE e no Sistema de lnformaróes de Projetos de

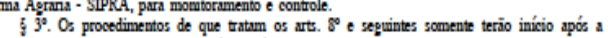

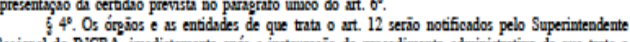
Regional do NCRA, imediatamente após a inttauragio do prosedimento administrativo de que trata o caput, com o objetivo de apresentarem, se assim entenderem necessíno, informagóes que possam
contribuir com os estados previstos nos arts. $8^{\circ} \mathrm{e}$ seguntes.

IDENTIFICAÇĀO E DELDMTAÇÃO

Art. $8^{\circ}$. 0 estudo e a definigäo da tema reivindicada seräo precedidos de reuniöes com a conuridade o Grupo Técrico interdisciplinar, nomeado pela Superintendénecia Regional do DNCRA, pura apresentagio dos procedimentos que serio adotados.

Art 90. A identifiospio dos limites das ternas das comunidades remanescentes de quilombos a

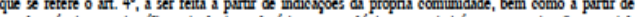

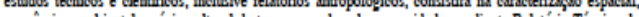

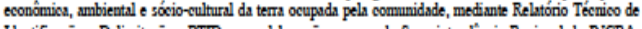
Identificagio e Delimithyjio - RTID, com elaboraģio a cargo da Superintendência Regional do NCRA, que o remeterí, após cosclúío, so Comité de Decisio Regional, pura decisio e encanninhamentos

Art. 10. $0 \mathrm{KTD}$, devidamente fundanentado em elementos objetivos, abordando informagroes

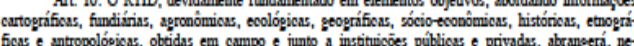

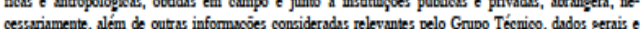
especificos orpanizados da seguinte forms:

I- Relatónio antropolópico de carracterizaçio histócica, ecovômica, ambiental e sócio-cultural da

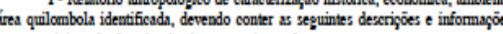

2) introduçio, abordando os seguintes elementos:

1. apresentap̧io dos conceitos e conceppöes empregados no Relatónio (refererencial toónico), que observem of entenos de anto-strbbuigio, que permita caracterizar a trajetoria histónica própria, as

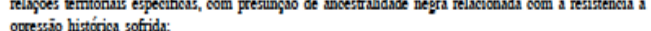
opressio histocica sofida;

2. apresentagio da metodologia e dos condicionantes dos trabalhos, contendo, dentre outras

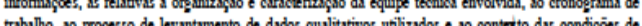
traballo, al processo de levantamento de dasto

b) dados gerais, contrendo

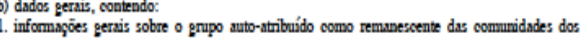
quilombos, tais como, dencminsagio, localizaģa e forms de acesso, dieposigaio espacial, appectos demograbicos, socisis e de infratestrunura,

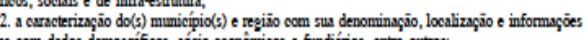
inas com dados demograficos, socio tconomicoss e fundanos, entre outros;

3. dados, quando disponiveis, sobre as tass de natalidade e mortalidade da comumidade nos

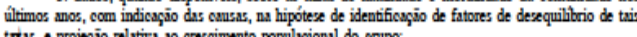

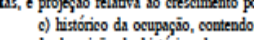

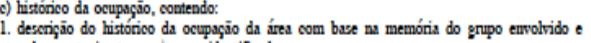

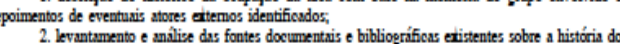

grupo e da sua terra;

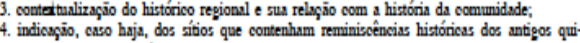
lambos, assim como de outros sitios considerados relevesntes pelo grupos

5. levantamento do putrimonio cultural da comunidade a partir do percurso histónico vivido

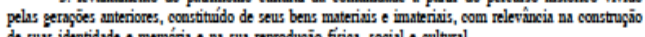

6. levantamento e andise dos processos de edproprispao, bem como de seews efeitos sobre a

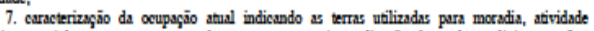

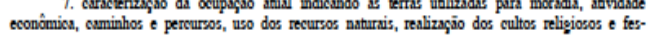
tividades, entre outras manifestances enlhrris

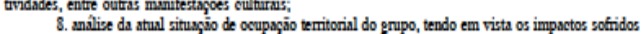

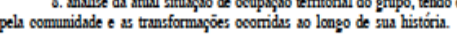

d) organizasio social, contendo:

1. identificapaio e corracterizagio dos sinais diacríbicos da identidade étuica do grupo:

2. identifiosgio e analise das formas de construpio e entérios do pertencimento e frontrias 3. ident

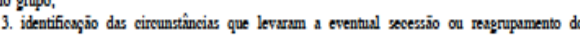
Grupo;

4. descrigiä da representaçăio genesalógica do grupo

membros do grupo em questio;

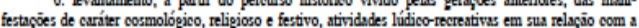

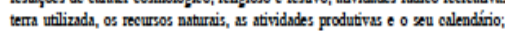


7. levantamento das prábicas tradicionsis de orríter coletivo e sua relagio com a ocupugion atual

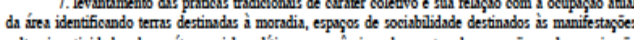

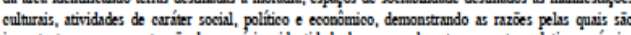
importantes para a manutengio da memoria e identidade do grupo e de cutros appectos ooletivios próprios menidsce

8. descricio das formas de representapio politica do grupo;

1. levantamento e andilise das cattegoris êmioss relasionads is terras e so ambiente onde viven midsdes e sua lópioa de apropriagio dessas áreas e configuragio de seus limite

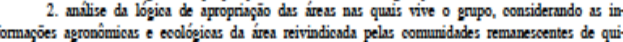

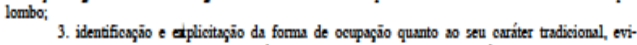
denciando $\mathrm{a}$ unidades de puisagem ditponíveis no presente e mo plano da memócia do grupo, bem com

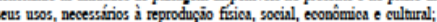

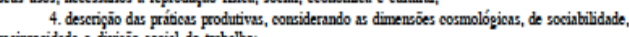
e divisaio social do traball

5. descrigajo das atividades produtivas deseavolvidas pela comunidade com a identificagaio,

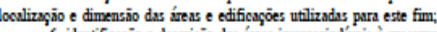

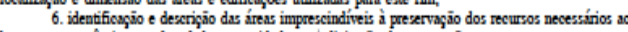

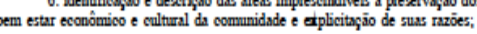

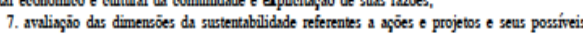

impustos junto as grupo emm quettio;
8. indicasio de obras e empreendimentos eristentes ou apontados como planejados, com in-

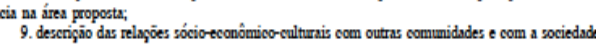

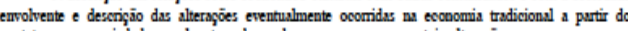
contato com a socieddade envolvente e do modo como se processam tajis alterą̧⿻es;

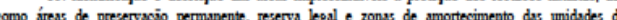

conservachio.

1. proposta de delimitapio da tema, tendo como base os estudos previstos neste inciso $\mathrm{I}$

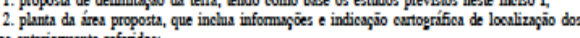
elementos anterionmente referidos

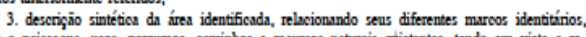

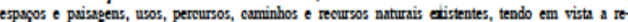
produgyio fivios, yocial e cultural do grupo, segundo seus usos, costumes e tradiçoes:

possam ser, oportumamentat, aproveitadar;

II - levantamento fimdiário, derendo conter a seguninte deserịio e informaryoue:

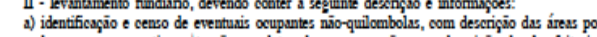

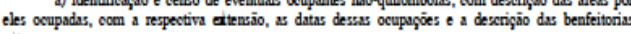

existentes;

descriçio das áreas pertencentes a quilombolas, que têm táblo de propriedade:

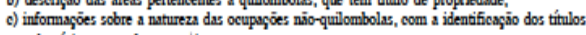
de posse ou dommo eventualimente ceistentes,

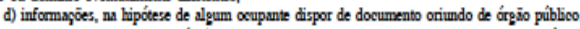

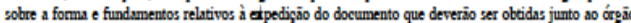
expedidor,

III - planta e memorial descritivo do perímetro da área revinindicada pelas comunidades re-

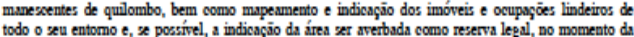
titulaçäio;

IV - cadastramento das famlias remanesentes de conmuxidades de quilombos, uálizando-x malários específicos do NCRA;

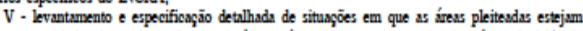
sobrepostas a unidndes de conservagio constitúfas, a áreas de segurama nacional, a áress de faita de NCRA ou Secretania do Patrimônio da Uniäo e em terras dos estados e muniépios; e

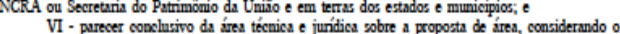
studos e documentos aprezentados.

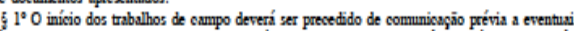
proprictarios ou ocupuntes de terras localizadas na írea pleiteada, com antecedécencia mínima de 3 (três)

20. O Relatónio de que trath o inciso I deste artigo será elaborado por espocialista que

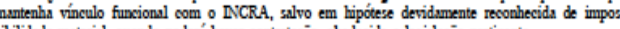
ida a legislagajo pertinente.

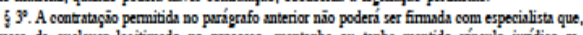
so interesse de qualquer le

lacionsdo at objeto do inciso I. qualquer questio de competéncia dos órgios e entidades enumerados no art. 12 , o Superintendente Regional do NCRA deverí comminicá-los, para scompanhamento, sem prejuízo de prosseguimento dos trabullhos.

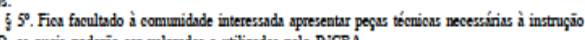
RTD, as quais poderaio ser valoradas e utibizadas pelo NCRA.

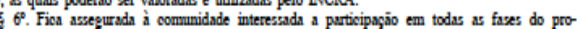
cedinento administrativo de elaboragio do RTID, diretumente ou por meio de representantes por els (a)

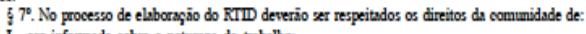
- ger informada sobre a antureza do trabullho;

II - preservagio de sua intimidade, de acordo com rew padröes culaura is

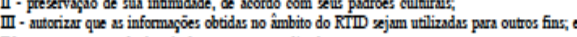

IV - acesso aos resultados do levantamento realizado.

PUBLICDDADE

Art. 11. Estando em ternos, o RTD seráa submetido à analise prelinimar do Comitê de Decisäo Regional do NCRA que, venticesndo o attendimento dos critenios estabelecidos para sua elaborajio, o

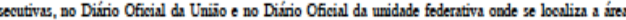
sob estudo, contendo as seguintes informspos:

I- denominạjio do imórel ocupado pelos remanesentes das commindades dos quilombos

II - eircumecrigio judiciaria ou administrativa em qux esté situado o imovel: inlahdres;
IV - tralos, registros e matrículas eventulmente incidentes sobre as teras consideradas sav-

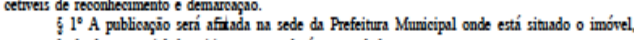
compunhada de memonial deseritivo e mapa da area estudada

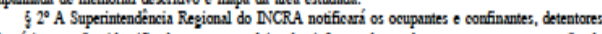
de domínio ou nio, identificados an tera pleitrada, informando-os do prazo para apresentagio de contestạ̧és. - Comité de Decisaro Regional do DCRA o devolvería ao Coordenador do Grupo Téeniso Intererte artion.

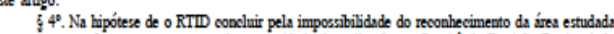
mo terra ocupada por remanescente de comunidade de quilombo, 0 Comitê de Decisio Regional do

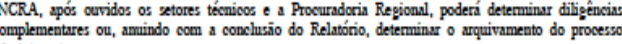
dministrativo.

5. $5^{\circ}$. A conunidade interessada e a Fundsgio Cultural Palmases serio notificadss da decisio

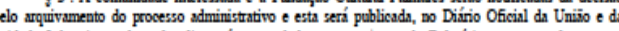
midade federativa onde $s$ localiza a íres estudada, com o etrato do Relatónio, que contenha os seut

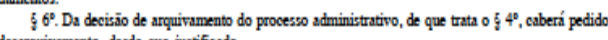
desaguivamento, devde que justifosado. aresentes das conunidades dos quilombos. CONSUZTA A ÓRGĀOOS E ENTIDADES

Art. 12. Concomitantemente a sua publicaşāo, O RTD será remetido sos órgäos e entidades abaito relacionados, para, no prazo comum de 30 (trinta) dias, apreerentasem manifestapio sobre as de suas respectivas competencias:

I - Intrituto do Património Hirtónico e Artírtico Nacional - PHAN;

II- Instiato Brasileiro do Meio Ambiente e dos Recurros Naturasis Renovíveis - BBAMA, e seu III - Secrearia do Patrimônio da Uniizo - SPU, do Ministénio do Planxjumento, Orçamento e

Gestio;

V- Fecretania Frocutiva do Canselho de Defens Nacional - CDN;

VI - Fundasyio Cultural Palmares

VII - Instituto Chico Mendes de Conservagio da Biodiveridade - ICMBio, e seu correspondente an Administragio Estadulit; e

VIII - Serviço Florestal Brasieiro - SFB.

6 $1^{\circ}$. O Presidente do INCRA encaminhará o RTID a outos órgajos e entidades da Administraģio Pública Federal, quando verifique repercuussio em sas áreas de interesse, observado o procedimento previsto neste artigo

meterí o arquivo digital do memorial descritivo (shape file) ì Secretania Eaceutiva do Conselho de Defesa Nacional, pura inclusio em sistema georreferencisdo, de amplo acesso de todos os órpaios e entidades.

3. Exprado o prazo de 30 (trinta) diss consecutivos, contados do recebimento da cópia do

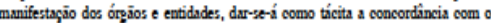
conteúdo.

5 40. O NCCRA terá um prazo de 30 (trinta) dias para adotar as medidas cabriveis diante de

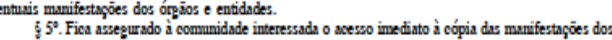
orgäos e entidades referidos neste artigo, bem como o accompunhmento das medidas decorrentes das reppectivas manifestapöes.

\section{CONTESTAÇŌES}

Art. 13. Os interessados terio o prazo de noventa dias, após a publicagāo e as notifiogyoues, pusa contertarem o RTID jumto ì Superintendência Regional do NCCRA, juntando as proves pertinentes. surpentivo

Art. 14. As contertsayces dos interessados indiosdos no art. 12 serio analisadss e julgadas pelo Conite de Decisão Regional do NNCRA, após ourvidos os setores técnicos e a Procuradoria Regional em

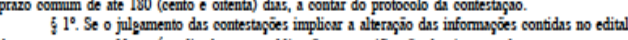

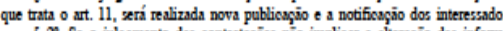

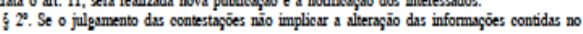
edital de que trata 0 art. 11, serio notificados os interessados que as ofereveram

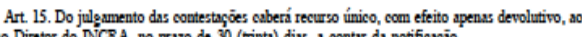

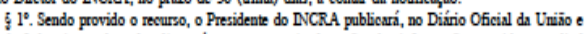

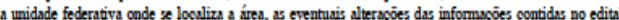
de que trata 0 art. 11 e notificaría o recocrente.

5. $2^{\circ}$. Nio sendo provido o recurso, o Presidente do NCRA notificará de decisaio o re-

ANÁLISE DA STTUAÇÃO FUNDIÁrIA DAS ÁREAS PLETTEADAS

Art. 16. Incidindo as terns identificadas e delimitadss pelo RTID sobre unidsdes de conservapāo

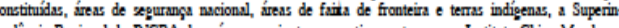
vendencia Regional do ICRA devera, em conjumto, respectivanzente, com o Instatito Clico Mendes, a Secretara Erecutiva do Consel ho de Defesa Nacional ou a FUNAI, adotar as medidas cabrivis, visando

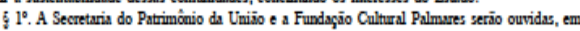
odos os casos.

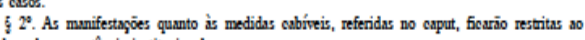

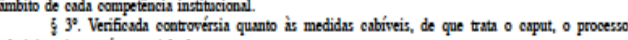

I - em $x$ tratando do mérito, à Casa Civil da Presidência da Republisa, para o cetercíxio de sua

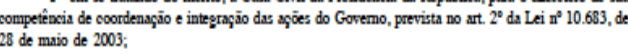


II - sobre questio juŕdica, an Adrogado-Geral da Uniäo, para o ecercécio de sua competência, prevista no at. 49 , inciso XI da Lei Complenentar $n^{\circ} 73$, de 10 de fevereiro de $1993 \mathrm{e} 0$ art. $8{ }^{\circ} \mathrm{C}$, de Lei no $^{\circ} 9.028$, de 12 de abril de 1995 .

$54^{\circ}$. A 12 de the de disposto neste artigo.

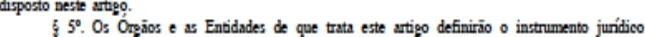
apropriado a garantir a permanência e os uros conferidos à terra pela communidade quilombola enquanto persistir a sobreposiça de interesses.

Art. 17. Conclúdas as fases a que se referem os asts. 14, 15 e 16, o Preidente do NCCRA

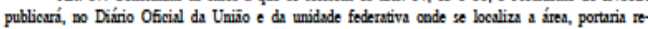
conhecendo e declarando os limites da tera quilombola, no prazo de 30 (tinta) dias.

Art. 18. Se ss terras reconhecidss e declarndss incidirem sobre terrenos de marinha, marginais de rios, ilhas e lagos, a Superintendência Regional do DCCRA enominharí o proceesso a SPU, para a emiessäo de tínlo em benefíio das comunidades quilombolss.

Art. 19. Constatada a incidencia nas terras reconbecidas e declsadas de pose particular sobre

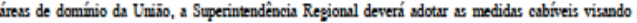
retomada da área.

Art. 20. Incidindo as terras reconhecidas e declaradas sobre íreas de propriedade dos Estados, do Distrito Federal ou dos Muricípios, a Superintendência Regional do NCCR encuminhará os anto para os órgäos responsáveis pela tinalsyio no âmbito de tais entes federados.

Parígrafo único. A Superintendênecia Regional do INCRA poderá propor a celebragäo de

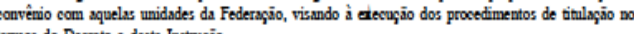
temmos do Decreto e desta Intrugấ.

Art. 21 Incidindo as terras recoonhecidss e declarads em imórel com tátlo de domínio pustieular nio invalidado por nulidade, preecricio ou comisso, e nem tomado ineficaz por outros fun-

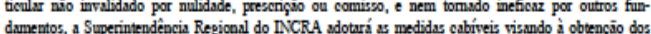
imóvers, mediante a intanuragio do procedimento de desapropriaşio.

Art. 22. Verifosada a presenga de ocupuntes näo quilombolas nas terras dos remanescentes das comunidades dos quilombor. a Superintendencis Fegional do INCRA providenciará o ressentemento em outras áreas des familis de agricultores que preencherem os requivitos da legielagio agrín.

$$
\text { DEMARCAÇĀo }
$$

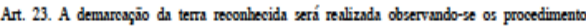
contidos na Norma Tecmica para Georreferencimento de imoveis nurais aprorsda pela Portania no 1.101 , de 19 de nortembro de 2003, do Presicente do NCRA e demas atos regulamentares expedidos pet Autarquin, em atendimento à Lei no 10.267 , de 28 de agosto de $200 \mathrm{H}$.

QUADRO COMPARATIVO ENTRE O TEXTO RESTLTADO DO GRUPO DE TRABALHO COORDENADO PELA ADVOCACLA-GERAL DA UNLīO E OS RESTLTADOS DA CONSULTA PÚBLICA DE COMUNIDADES QULLOMBOLAS, APÓS A SISTEMATZZAÇÃo

NSTRUÇÃO NORMATTVA No

DE_ DE_ DE 2008

\begin{tabular}{|c|c|c|}
\hline TEXTO DO GRUPO DE TRABALHO & $\begin{array}{l}\text { TEXTO DE CONSENSO } \\
\text { EMI } 17 \text { DE ABRII DE } 2008\end{array}$ & TEXTO SEM CONSENSO \\
\hline \multicolumn{3}{|c|}{ EMIENTA } \\
\hline 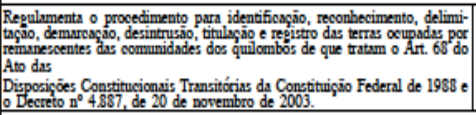 & & $\begin{array}{l}\text { A N DEVERA UTMIZAR O TERYO TERRTOORIO } \\
\text { AO NVES DE TERRA OU AREA }\end{array}$ \\
\hline 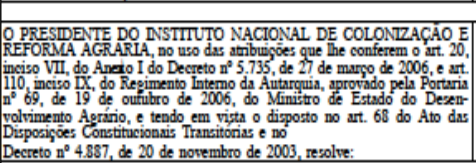 & (PRESMALO:) & \\
\hline \multicolumn{3}{|l|}{ 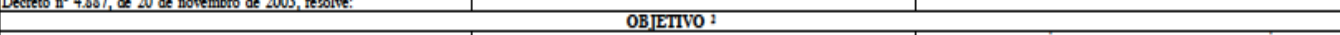 } \\
\hline 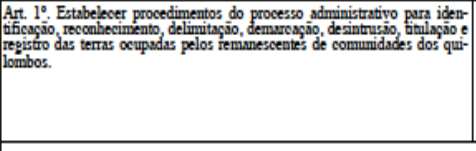 & & 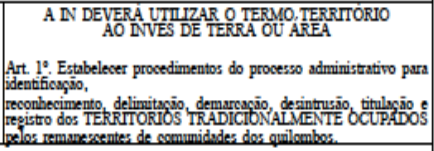 \\
\hline & 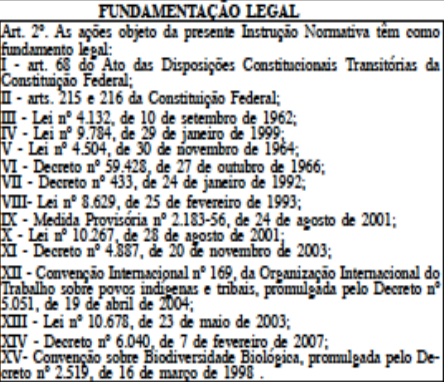 & \\
\hline
\end{tabular}

Art. 24. O Presidente do DNCRA reslizaría a titulagäo mediante a outorga de túnlo coletivo e

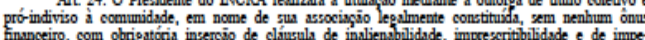
nhorabilidade, devidenente registrada no Servigo Registral da Comarca de localizagaio das áreas.

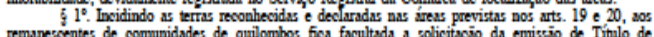

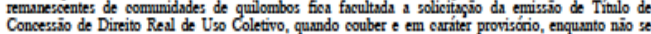
ultima a concessio do Título de Reconhecimento de Domínio, pura ques possam ederver direitos resis

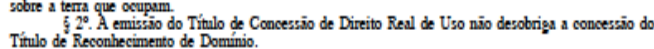
anlombos, independentemente do tamanho da ím.

Art. 26. Esta Inetrugaio Normativa aplica-se desde logo, sem prejuizo da validade das fases

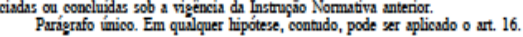

$$
\text { DISPOSIÇŌES GERAIS }
$$

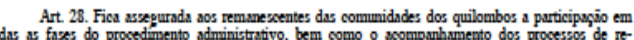
enlarizagio em tranite na Superintendéncia Regional do NCCRA, diretamente ou por meio de retentantes por eles indicasdos.

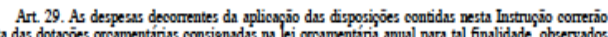
os limites de movimentagio, empenbo e papanento.

Art. 30. A Superintendêpcia Repional do NCRA encaminhará à Fundagiono Cullural Palmures e

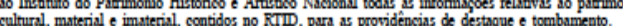

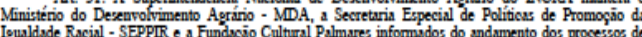
areularizapio das terras de remunescentes de quilombog.

Art. 32. Revoga-se a Instrugaio Nonmativa no 20, de 19 de setembro de 2005.

Art. 33. Esta Instrugiono Normativa entra em vigor na data de sua publicaģo.

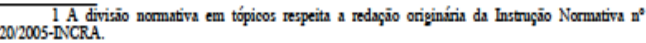

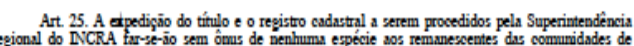

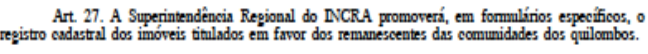

Art. 31. A Superintendência Nacional de Desenvolvinento Agrírio do NCRA manterí o 


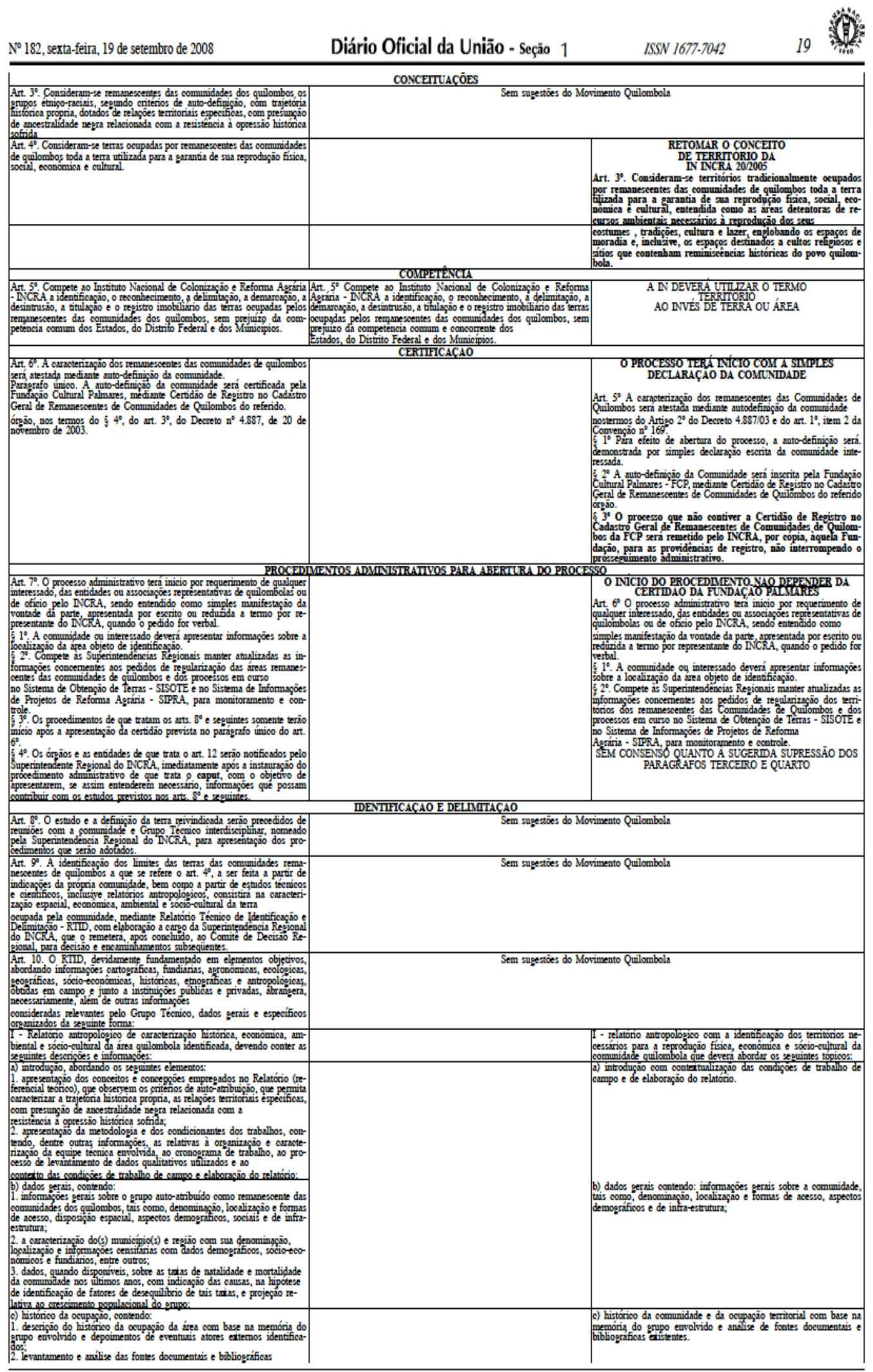




\begin{tabular}{|c|c|c|}
\hline ISSN 1677.7042 & Diário Oficial da Uniāo - Seção 1 & NN 182, sexta-fera, 19 de setembro de 2008 \\
\hline 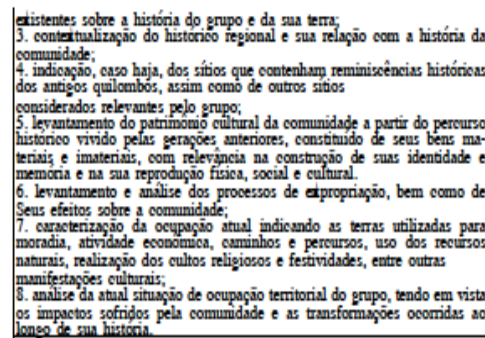 & & \\
\hline 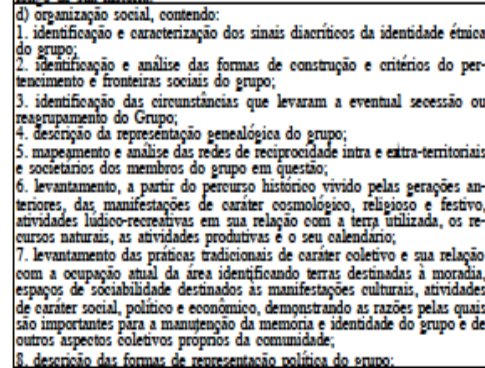 & & 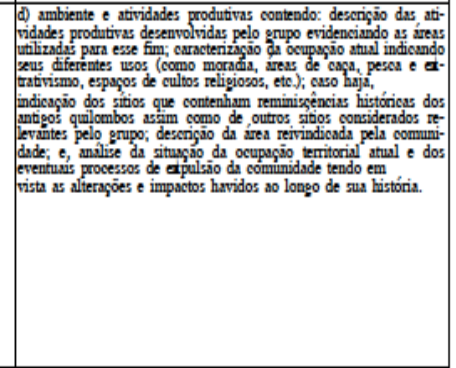 \\
\hline 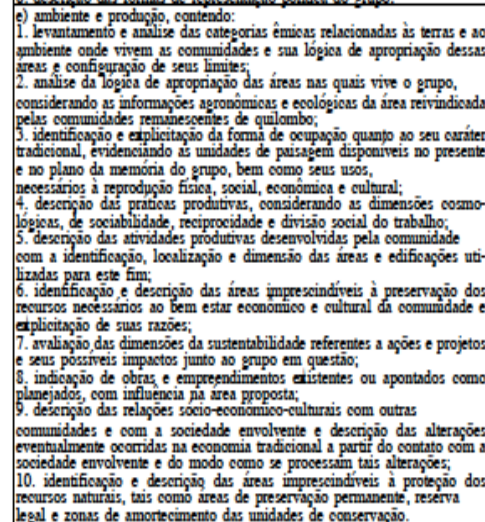 & & Vide alinen "d' \\
\hline 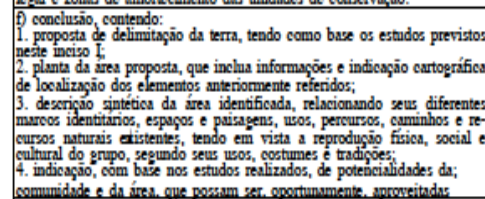 & & 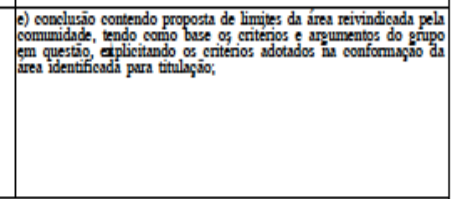 \\
\hline 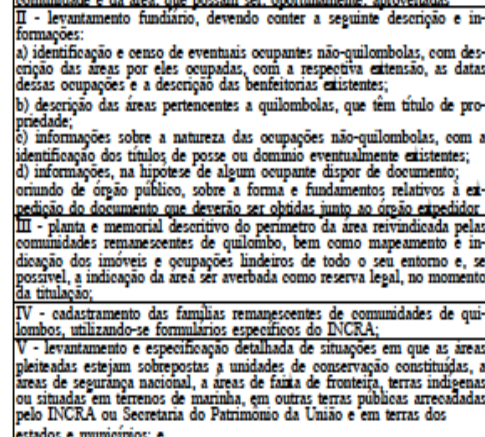 & \multirow{2}{*}{\multicolumn{2}{|c|}{ Sen Ingerties do Morimento Qullombla }} \\
\hline 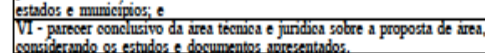 & & \\
\hline 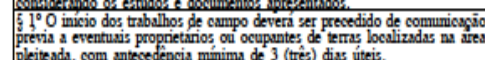 & Sem syertieses do I. & Torimento Qullombola \\
\hline 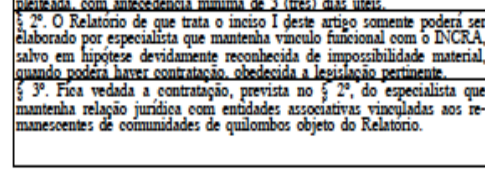 & 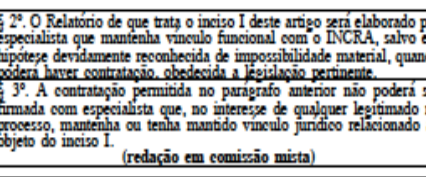 & \\
\hline
\end{tabular}




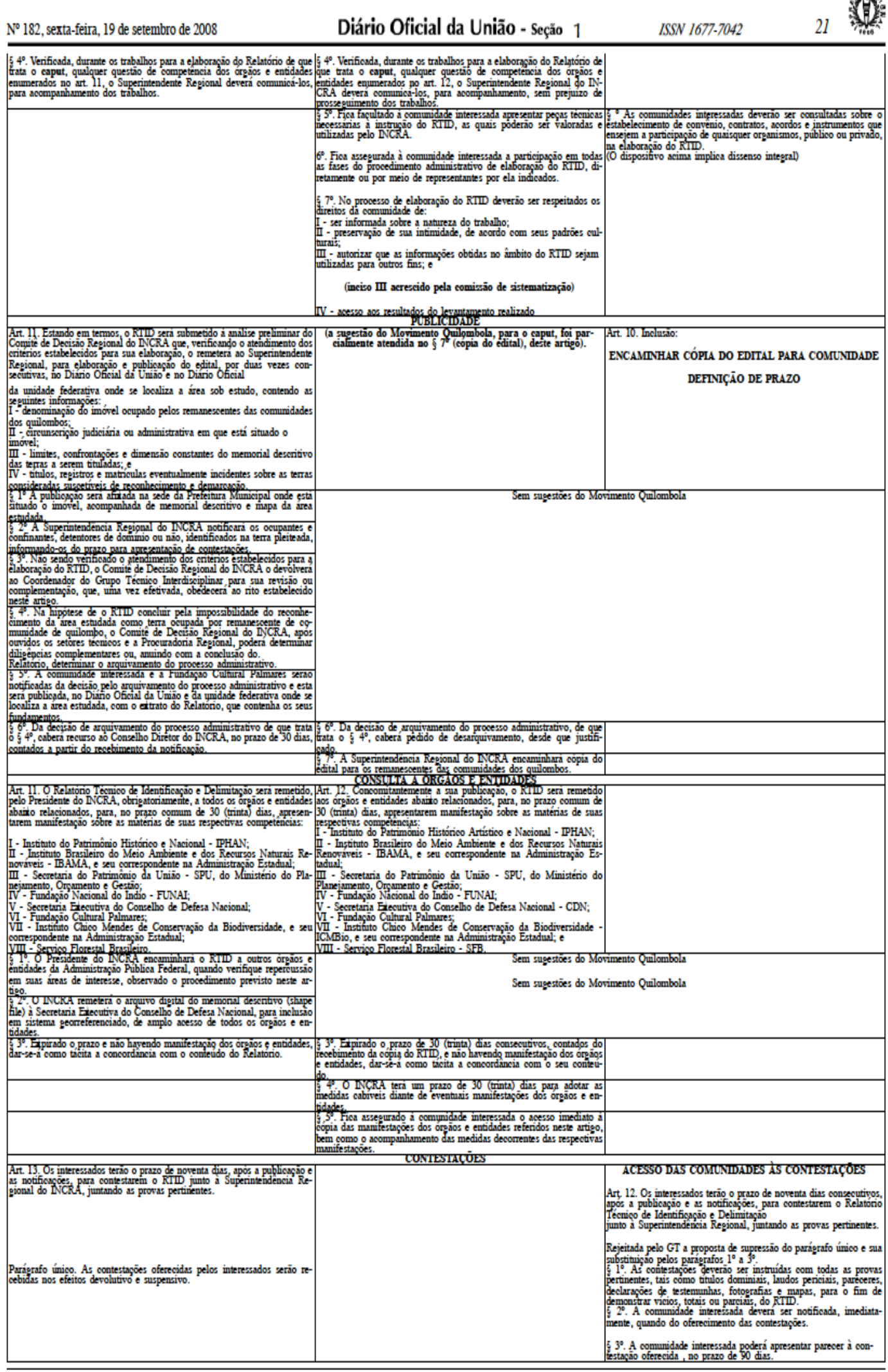




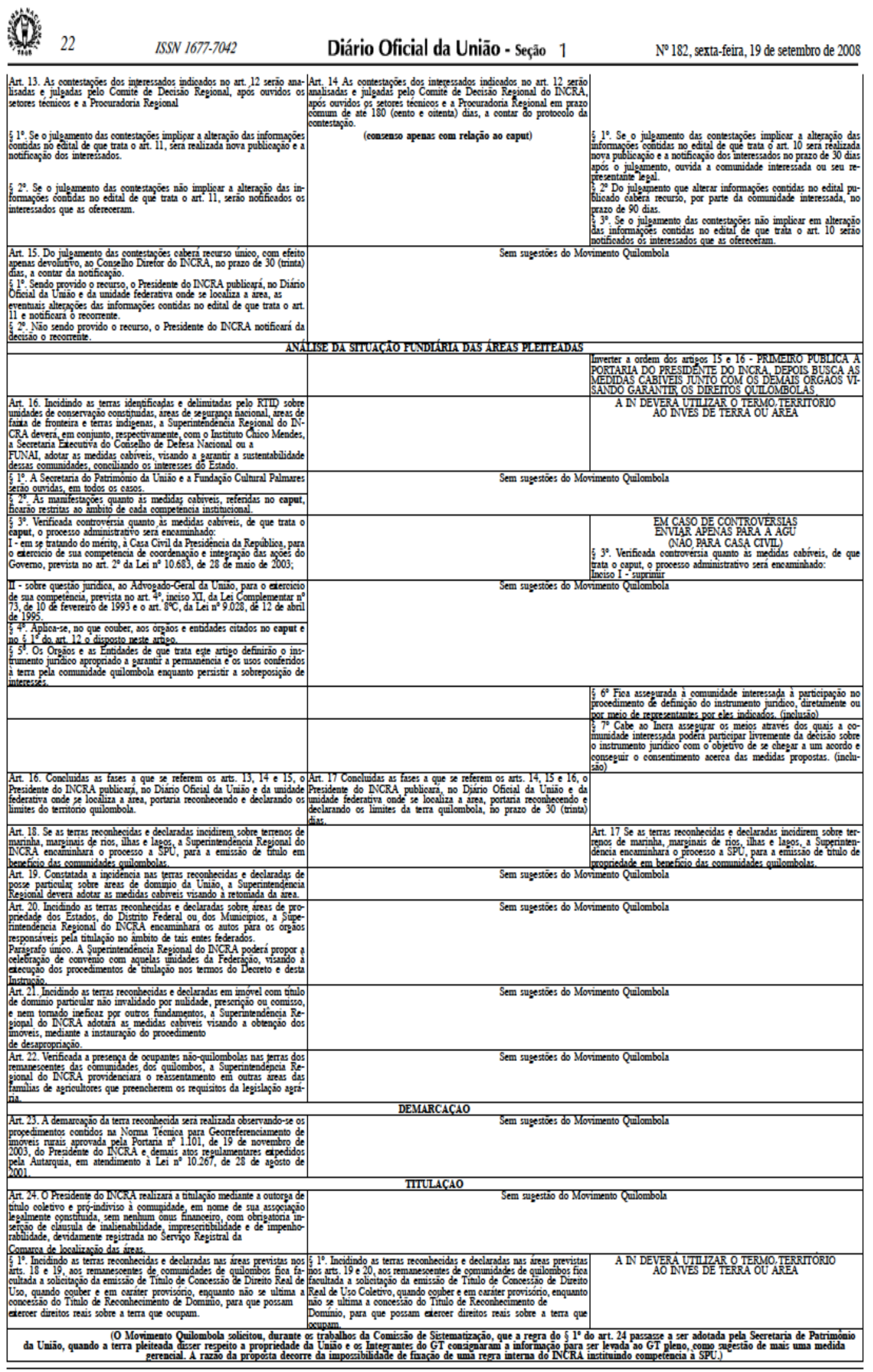




\begin{tabular}{|c|c|}
\hline 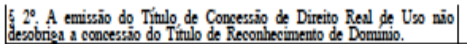 & Sem sugertioes do Morimento Qullombola \\
\hline 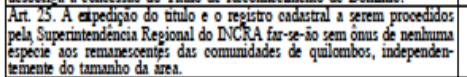 & Sem sugertioes do Morimento Quilombola \\
\hline 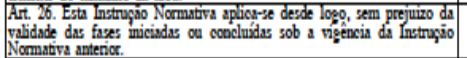 & Sem sugertioes do Morimento Quilombola \\
\hline 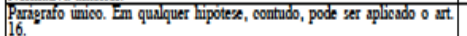 & Suprimir purigrafo ímico do att 25 \\
\hline 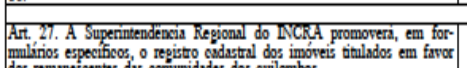 & Sem rugertoés do Morimento Qullombola \\
\hline 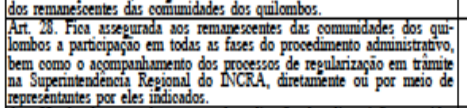 & Sem sugertioes do Morimento Qumlombola \\
\hline 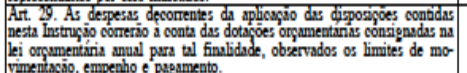 & Sem sugertoes do Morimento Quilombola \\
\hline 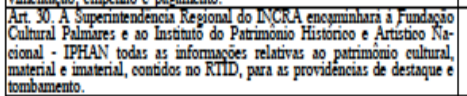 & Sem sugertioes do Morimento Qumlombola \\
\hline 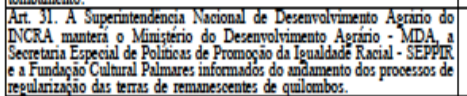 & Sem sugestóes do Morimento Qurlombola \\
\hline 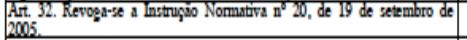 & Sem sugertioes do Morimento Quilombola \\
\hline $\begin{array}{l}\text { Art. 33. Esta Instrugaio Normativa entra em rigor na data de sua pu- } \\
\text { bickscio. }\end{array}$ & Sem sugertöes do Morimento Qulombola \\
\hline
\end{tabular}

Teito encerrado, na Comissaio de Sistrmatizagio, is 15 horas e 55 minutos, do din 5 de majo de 2008.

OBSERVAÇÕES:

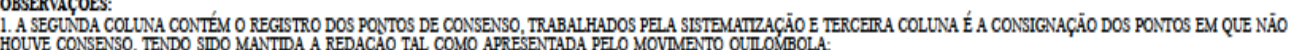
2. COMO HAVIA UMA DUVIDA SOBRE A NECESSDADE DE COLOCAR GENERICAMENTE A REFERENCIA AOS SISTEMAS NFORMATZADOS DO NCRA, REFERIDOS NO ART. $6^{\circ}, \xi 2^{2}$, FOI

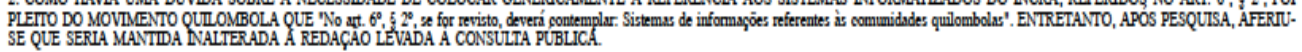

\section{NOTAS DE RODAPÉ:}

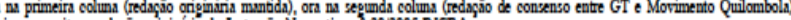

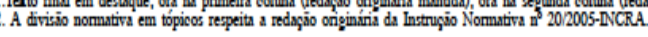




\title{
ANEXO V - INSTRUÇÃO NORMATIVA No 49 (INCRA), DE 29 DE SETEMBRO DE 2008 (POSTERIORMENTE ALTERADA PELA INSTRUÇÃO NORMATIVA No 57 (INCRA), DE 20 DE OUTUBRO DE 2009
}

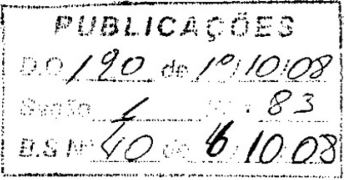

INSTRUÇĀO NORMATIVA No ${ }^{\circ} 9$

DE 29 DE SETEMBRO DE 2008.

\begin{abstract}
Regulamenta o procedimento para identificação, reconhecimento, delimitação, demarcação, desintrusão, titulação e registro das terras ocupadas por remanescentes das comunidades dos quilombos de que tratam o Art. 68 do Ato das Disposições Constitucionais Transitórias da Constituição Federal de 1988 e o Decreto $n^{\circ} 4.887$, de 20 de novembro de 2003.
\end{abstract}

O PRESIDENTE DO INSTITUTO NACIONAL DE COLONIZAÇÃO E REFORMA AGRÁRIA, no uso das atribuições que lhe conferem o art. 20, inciso VII, do Anexo I, do Decreto $\mathrm{n}^{\circ} 5.735$, de 27 de março de 2006, e art. 110, inciso IX, do Regimento Interno da Autarquia, aprovado pela Portaria $n^{\circ} 69$, de 19 de outubro de 2006, do Ministro de Estado do Desenvolvimento Agrário, e tendo em vista o disposto no art. 68 do Ato das Disposições Constitucionais Transitórias e no Decreto ${ }^{\circ} 4.887$, de 20 de novembro de 2003, resolve:

\section{OBJETIVO}

Art. $1^{\circ}$. Estabelecer procedimentos do processo administrativo para identificação, reconhecimento, delimitação, demarcação, desintrusão, titulação e registro das terras ocupadas pelos remanescentes de comunidades dos quilombos.

\section{FUNDAMENTAÇÃO LEGAL}

Art. $2^{\circ}$. As ações objeto da presente Instrução Normativa têm como fundamento legal:

I - art. 68 do Ato das Disposições Constitucionais Transitórias da Constituição Federal

II - arts. 215 e 216 da Constituição Federal;

III - Lei $\mathrm{n}^{\circ} 4.132$, de 10 de setembro de 1962 ;

IV - Lei n ${ }^{\circ} 9.784$, de 29 de janeiro de 1999;

V - Lei n ${ }^{\circ} 4.504$, de 30 de novembro de 1964;

VI - Decreto $\mathrm{n}^{\circ} 59.428$, de 27 de outubro de 1966;

VII - Decreto ${ }^{\circ} 433$, de 24 de janeiro de 1992 ; 
VIII- Lei n ${ }^{\circ} 8.629$, de 25 de fevereiro de 1993;

IX - Medida Provisória n².183-56, de 24 de agosto de 2001;

$\mathrm{X}$ - Lei $\mathrm{n}^{\circ} 10.267$, de 28 de agosto de 2001 ;

XI - Decreto $\mathrm{n}^{\circ} 4.887$, de 20 de novembro de 2003;

XII - Convenção Internacional $\mathrm{n}^{\circ} 169$, da Organização Internacional do Trabalho sobre povos indígenas e tribais, promulgada pelo Decreto $\mathrm{n}^{\circ} 5.051$, de 19 de abril de 2004;

XIII - Lei n ${ }^{\circ} 10.678$, de 23 de maio de 2003;

XIV - Decreto ${ }^{\circ} 6.040$, de 7 de fevereiro de 2007;

$\mathrm{XV}$ - Convenção sobre Biodiversidade Biológica, promulgada pelo Decreto $\mathrm{n}^{\circ} 2.519$, de 16 de março de 1998.

\section{CONCEITUAÇÕES}

Art. $3^{\circ}$. Consideram-se remanescentes das comunidades dos quilombos os grupos étnico-raciais, segundo critérios de auto-definição, com trajetória histórica própria, dotados de relações territoriais específicas, com presunção de ancestralidade negra relacionada com a resistência à opressão histórica sofrida.

Art. $4^{\circ}$. Consideram-se terras ocupadas por remanescentes das comunidades de quilombos toda a terra utilizada para a garantia de sua reprodução física, social, econômica e cultural.

\section{COMPETÊNCIA}

Art. $5^{\circ}$. Compete ao Instituto Nacional de Colonização e Reforma Agrária INCRA a identificação, o reconhecimento, a delimitação, a demarcação, a desintrusão, a titulação e o registro imobiliário das terras ocupadas pelos remanescentes das comunidades dos quilombos, sem prejuízo da competência comum e concorrente dos Estados, do Distrito Federal e dos Municípios.

\section{CERTIFICAÇÃO}

Art. $6^{\circ}$. A caracterização dos remanescentes das comunidades de quilombos será atestada mediante auto-definição da comunidade.

Parágrafo único. A auto-definição da comunidade será certificada pela Fundação Cultural Palmares, mediante Certidão de Registro no Cadastro Geral de Remanescentes de Comunidades de Quilombos do referido órgão, nos termos do $\S 4^{\circ}$, do art. $3^{\circ}$, do Decreto $n^{\circ} 4.887$, de 20 de novembro de 2003.

PROCEDIMENTOS ADMINISTRATIVOS PARA ABERTURA DO PROCESSO 
Art. $7^{\circ} . O$ processo administrativo terá inicio por requerimento de qualquer interessado, das entidades ou associações representativas de quilombolas ou de ofício pelo INCRA, sendo entendido como simples manifestação da vontade da parte, apresentada por escrito ou reduzida a termo por representante do INCRA, quando o pedido for verbal.

$\S 1^{\circ}$. A comunidade ou interessado deverá apresentar informações sobre a localização da área objeto de identificação.

$\S 2^{\circ}$. Compete às Superintendências Regionais manter atualizadas as informações concernentes aos pedidos de regularização das áreas remanescentes das comunidades de quilombos e dos processos em curso nos Sistemas do INCRA.

$\S 3^{\circ}$. Os procedimentos de que tratam os arts. $8^{\circ}$ e seguintes somente terão início após a apresentação da certidão prevista no parágrafo único do art. $6^{\circ}$.

$\S 4^{\circ}$. Os órgãos e as entidades de que trata o art. 12 serão notificados pelo Superintendente Regional do INCRA, imediatamente após a instauração do procedimento administrativo de que trata o caput, com o objetivo de apresentarem, se assim entenderem necessário, informações que possam contribuir com os estudos previstos nos arts. $8^{\circ}$ e seguintes.

\section{IDENTIFICAÇÃO E DELIMITAÇÃO}

Art. $8^{\circ}$. O estudo e a definição da terra reivindicada serão precedidos de reuniões com a comunidade e Grupo Técnico interdisciplinar, nomeado pela Superintendência Regional do INCRA, para apresentação dos procedimentos que serão adotados.

Art. $9^{\circ}$. A identificação dos limites das terras das comunidades remanescentes de quilombos a que se refere 0 art. $4^{\circ}$, a ser feita a partir de indicações da própria comunidade, bem como a partir de estudos técnicos e científicos, inclusive relatórios antropológicos, consistirá na caracterização espacial, econômica, ambiental e sócio-cultural da terra ocupada pela comunidade, mediante Relatório Técnico de Identificação e Delimitação - RTID, com elaboração a cargo da Superintendência Regional do INCRA, que o remeterá, após concluído, ao Comitê de Decisão Regional, para decisão e encaminhamentos subseqüentes.

Art. 10. O RTID, devidamente fundamentado em elementos objetivos, abordando informações cartográficas, fundiárias, agronômicas, ecológicas, geográficas, sócio-econômicas, históricas, etnográficas e antropológicas, obtidas em campo e junto a instituições públicas e privadas, abrangerá, necessariamente, além de outras informações consideradas relevantes pelo Grupo Técnico, dados gerais e específicos organizados da seguinte forma:

I - Relatório antropológico de caracterização histórica, econômica, ambiental e sócio-cultural da área quilombola identificada, devendo conter as seguintes descrições e informações:

a) introdução, abordando os seguintes elementos:

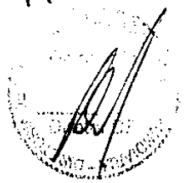


1. apresentação dos conceitos e concepções empregados no Relatório (referencial teórico), que observem os critérios de auto-atribuição, que permita caracterizar a trajetória histórica própria, as relações territoriais específicas, com presunção de ancestralidade negra relacionada com a resistência à opressão histórica sofrida;

2. apresentação da metodologia e dos condicionantes dos trabalhos, contendo, dentre outras informações, as relativas à organização e caracterização da equipe técnica envolvida, ao cronograma de trabalho, ao processo de levantamento de dados qualitativos utilizados e ao contexto das condições de trabalho de campo e elaboração do relatório;

b) dados gerais, contendo:

1. informações gerais sobre o grupo auto-atribuído como remanescente das comunidades dos quilombos, tais como, denominação, localização e formas de acesso, disposição espacial, aspectos demográficos, sociais e de infra-estrutura;

2. a caracterização do(s) município(s) e região com sua denominação, localização e informações censitárias com dados demográficos, sócio-econômicos e fundiários, entre outros;

3. dados, quando disponíveis, sobre as taxas de natalidade e mortalidade da comunidade nos últimos anos, com indicação das causas, na hipótese de identificação de fatores de desequilíbrio de tais taxas, e projeção relativa ao crescimento populacional do grupo;

c) histórico da ocupação, contendo:

1. descrição do histórico da ocupação da área com base na memória do grupo envolvido e depoimentos de eventuais atores externos identificados;

2. levantamento e análise das fontes documentais e bibliográficas existentes sobre a história do grupo e da sua terra; comunidade;

3. contextualização do histórico regional e sua relação com a história da

4. indicação, caso haja, dos sítios que contenham reminiscências históricas dos antigos quilombos, assim como de outros sítios considerados relevantes pelo grupo;

5. levantamento do patrimônio cultural da comunidade a partir do percurso histórico vivido pelas gerações anteriores, constituído de seus bens materiais e imateriais, com relevância na construção de suas identidade e memória e na sua reprodução física, social e cultural. comunidade;

6. levantamento e análise dos processos de expropriação, bem como de

7. caracterização da ocupação atual indicando as terras utilizadas para moradia, atividade econômica, caminhos e percursos, uso dos recursos naturais, realização dos cultos religiosos e festividades, entre outras manifestações culturais;

8. análise da atual situação de ocupação territorial do grupo, tendo em vista os impactos sofridos pela comunidade e as transformações ocorridas ao longo de sua história. do grupo;

d) organização social, contendo:

1. identificação e caracterização dos sinais diacríticos da identidade étnica

2. identificação e análise das formas de construção e critérios do pertencimento e fronteiras sociais do grupo;

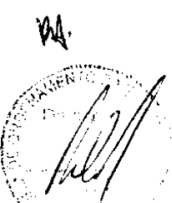


3. identificação das circunstâncias que levaram a eventual secessão ou reagrupamento do Grupo;

4. descrição da representação genealógica do grupo;

5. mapeamento e análise das redes de reciprocidade intra e extra-territoriais e societários dos membros do grupo em questão;

6. levantamento, a partir do percurso histórico vivido pelas gerações anteriores, das manifestações de caráter cosmológico, religioso e festivo, atividades lúdico-recreativas em sua relação com a terra utilizada, os recursos naturais, as atividades produtivas e o seu calendário;

7. levantamento das práticas tradicionais de caráter coletivo e sua relação com a ocupação atual da área identificando terras destinadas à moradia, espaços de sociabilidade destinados às manifestações culturais, atividades de caráter social, político e econômico, demonstrando as razões pelas quais são importantes para a manutenção da memória e identidade do grupo e de outros aspectos coletivos próprios da comunidade;

8. descrição das formas de representação política do grupo;

e) ambiente e produção, contendo:

1. levantamento e análise das categorias êmicas relacionadas às terras e ao ambiente onde vivem as comunidades e sua lógica de apropriação dessas áreas e configuração de seus limites;

2. análise da lógica de apropriação das áreas nas quais vive o grupo, considerando as informações agronômicas e ecológicas da área reivindicada pelas comunidades remanescentes de quilombo;

3. identificação e explicitação da forma de ocupação quanto ao seu caráter tradicional, evidenciando as unidades de paisagem disponiveis no presente e no plano da memória do grupo, bem como seus usos, necessários à reprodução física, social, econômica e cultural;

4. descrição das práticas produtivas, considerando as dimensões cosmológicas, de sociabilidade, reciprocidade e divisão social do trabalho;

5. descrição das atividades produtivas desenvolvidas pela comunidade com a identificação, localização e dimensão das áreas e edificações utilizadas para este fim;

6. identificação e descrição das áreas imprescindíveis à preservação dos recursos necessários ao bem estar econômico e cultural da comunidade e explicitação de suas razões;

7. avaliação das dimensões da sustentabilidade referentes a ações e projetos e seus possiveis impactos junto ao grupo em questão;

8. indicação de obras e empreendimentos existentes ou apontados como planejados, com influência na área proposta;

9. descrição das relações sócio-econômico-culturais com outras comunidades e com a sociedade envolvente e descrição das alterações eventualmente ocorridas na economia tradicional a partir do contato com a sociedade envolvente e do modo como se processam tais alterações;

10. identificação e descrição das áreas imprescindíveis à proteção dos recursos naturais, tais como áreas de preservação permanente, reserva legal e zonas de amortecimento das unidades de conservação.

f) conclusão, contendo:

1. proposta de delimitação da terra, tendo como base os estudos previstos neste inciso I

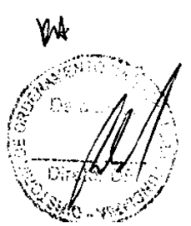


2. planta da área proposta, que inclua informações e indicação cartográfica de localização dos elementos anteriormente referidos;

3. descrição sintética da área identificada, relacionando seus diferentes marcos identitários, espaços e paisagens, usos, percursos, caminhos e recursos naturais existentes, tendo em vista a reprodução física, social e cultural do grupo, segundo seus usos, costumes e tradições;

4. indicação, com base nos estudos realizados, de potencialidades da comunidade e da área, que possam ser, oportunamente, aproveitadas; informações:

II - levantamento fundiário, devendo conter a seguinte descrição e

a) identificação e censo de eventuais ocupantes não-quilombolas, com descrição das áreas por eles ocupadas, com a respectiva extensão, as datas dessas ocupações e a descrição das benfeitorias existentes;

b) descrição das áreas pertencentes a quilombolas, que têm título de propriedade;

c) informações sobre a natureza das ocupações não-quilombolas, com a identificação dos títulos de posse ou domínio eventualmente existentes;

d) informações, na hipótese de algum ocupante dispor de documento oriundo de órgão público, sobre a forma e fundamentos relativos à expedição do documento que deverão ser obtidas junto ao órgão expedidor;

III - planta e memorial descritivo do perímetro da área reivindicada pelas comunidades remanescentes de quilombo, bem como mapeamento e indicação dos imóveis e ocupações lindeiros de todo o seu entorno e, se possivvel, a indicação da área ser averbada como reserva legal, no momento da titulação;

IV - cadastramento das famílias remanescentes de comunidades de quilombos, utilizando-se formulários específicos do INCRA;

V - levantamento e especificação detalhada de situações em que as áreas pleiteadas estejam sobrepostas a unidades de conservação constituídas, a áreas de segurança nacional, a áreas de faixa de fronteira, terras indígenas ou situadas em terrenos de marinha, em outras terras públicas arrecadadas pelo INCRA ou Secretaria do Patrimônio da União e em terras dos estados e municípios; e

VI - parecer conclusivo da área técnica e jurídica sobre a proposta de área, considerando os estudos e documentos apresentados.

$\S 1^{\circ} \mathrm{O}$ início dos trabalhos de campo deverá ser precedido de comunicação prévia a eventuais proprietários ou ocupantes de terras localizadas na área pleiteada, com antecedência mínima de 3 (três) dias úteis.

$\S 2^{\circ}$. O Relatório de que trata o inciso I deste artigo será elaborado por especialista que mantenha vínculo funcional com o INCRA, salvo em hipótese

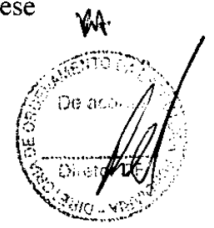


devidamente reconhecida de impossibilidade material, quando poderá haver contratação, obedecida a legislação pertinente.

$\S 3^{\circ}$. A contratação permitida no parágrafo anterior não poderá ser firmada com especialista que, no interesse de qualquer legitimado no processo, mantenha ou tenha mantido vínculo jurídico relacionado ao objeto do inciso I.

$\S 4^{\circ}$. Verificada, durante os trabalhos para a elaboração do Relatório de que trata o caput, qualquer questão de competência dos órgãos e entidades enumerados no art. 12, o Superintendente Regional do INCRA deverá comunicá-los, para acompanhamento, sem prejuízo de prosseguimento dos trabalhos.

$\S 5^{\circ}$. Fica facultado à comunidade interessada apresentar peças técnicas necessárias à instrução do RTID, as quais poderão ser valoradas e utilizadas pelo INCRA.

$\S 6^{\circ}$. Fica assegurada à comunidade interessada a participação em todas as fases do procedimento administrativo de elaboração do RTID, diretamente ou por meio de representantes por ela indicados.

$\S 7^{\circ}$. No processo de elaboração do RTID deverão ser respeitados os direitos da comunidade de:

I - ser informada sobre a natureza do trabalho;

II - preservação de sua intimidade, de acordo com seus padrões culturais;

III - autorizar que as informações obtidas no âmbito do RTID sejam utilizadas para outros fins; e

IV - acesso aos resultados do levantamento realizado.

\section{PUBLICIDADE}

Art. 11. Estando em termos, o RTID será submetido à análise preliminar do Comitê de Decisão Regional do INCRA que, verificando o atendimento dos critérios estabelecidos para sua elaboração, o remeterá ao Superintendente Regional, para elaboração e publicação do edital, por duas vezes consecutivas, no Diário Oficial da União e no Diário Oficial da unidade federativa onde se localiza a área sob estudo, contendo as seguintes informações: dos quilombos

I - denominação do imóvel ocupado pelos remanescentes das comunidades

II - circunscrição judiciária ou administrativa em que está situado o imóvel;

III - limites, confrontações e dimensão constantes do memorial descritivo das terras a serem tituladas; e

胡.

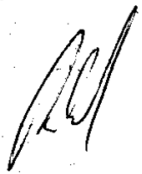


IV - títulos, registros e matrículas eventualmente incidentes sobre as terras consideradas suscetíveis de reconhecimento e demarcação.

$\S 1^{\circ}$ A publicação será afixada na sede da Prefeitura Municipal onde está situado o imóvel, acompanhada de memorial descritivo e mapa da área estudada.

$\S 2^{\circ}$ A Superintendência Regional do INCRA notificará os ocupantes e confinantes, detentores de domínio ou não, identificados na terra pleiteada, informandoos do prazo para apresentação de contestações.

$\S 3^{\circ}$. Não sendo verificado o atendimento dos critérios estabelecidos para a elaboração do RTID, o Comitê de Decisão Regional do INCRA o devolverá ao Coordenador do Grupo Técnico Interdisciplinar para sua revisão ou complementação, que, uma vez efetivada, obedecerá ao rito estabelecido neste artigo.

$\S 4^{\circ}$. Na hipótese de o RTID concluir pela impossibilidade do reconhecimento da área estudada como terra ocupada por remanescente de comunidade de quilombo, o Comitê de Decisão Regional do INCRA, após ouvidos os setores técnicos e a Procuradoria Regional, poderá determinar diligências complementares ou, anuindo com a conclusão do Relatório, determinar o arquivamento do processo administrativo.

$\S 5^{\circ}$. A comunidade interessada e a Fundação Cultural Palmares serão notificadas da decisão pelo arquivamento do processo administrativo e esta será publicada, no Diário Oficial da União e da unidade federativa onde se localiza a área estudada, com o extrato do Relatório, que contenha os seus fundamentos.

$\S 6^{\circ}$. Da decisão de arquivamento do processo administrativo, de que trata o $\S 4^{\circ}$, caberá pedido de desarquivamento, desde que justificado.

$\S 7^{\circ}$. A Superintendência Regional do INCRA encaminhará cópia do edital para os remanescentes das comunidades dos quilombos.

\section{CONSULTA A ÓRGÃOS E ENTIDADES}

Art. 12. Concomitantemente a sua publicação, o RTID será remetido aos órgãos e entidades abaixo relacionados, para, no prazo comum de 30 (trinta) dias, apresentarem manifestação sobre as matérias de suas respectivas competências:

I - Instituto do Patrimônio Histórico e Artístico Nacional - IPHAN;

II - Instituto Brasileiro do Meio Ambiente e dos Recursos Naturais Renováveis - IBAMA, e seu correspondente na Administração Estadual;

III - Secretaria do Patrimônio da União - SPU, do Ministério do Planejamento, Orçamento e Gestão;

IV - Fundação Nacional do Índio - FUNAI;

V - Secretaria Executiva do Conselho de Defesa Nacional - CDN;

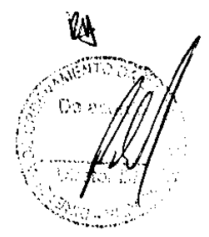




\section{VI - Fundação Cultural Palmares;}

VII - Instituto Chico Mendes de Conservação da Biodiversidade - ICMBio, e seu correspondente na Administração Estadual; e

\section{VIII - Serviço Florestal Brasileiro - SFB.}

$\S 1^{\circ}$. O Presidente do INCRA encaminhará o RTID a outros órgãos e entidades da Administração Pública Federal, quando verifique repercussão em suas áreas de interesse, observado o procedimento previsto neste artigo.

$\S 2^{\circ}$. O INCRA remeterá o arquivo digital do memorial descritivo (shape file) à Secretaria Executiva do Conselho de Defesa Nacional, para inclusão em sistema georreferenciado, de amplo acesso a todos os órgãos e entidades.

$\S 3^{\circ}$. Expirado o prazo de 30 (trinta) dias consecutivos, contados do recebimento da cópia do RTID, e não havendo manifestação dos órgãos e entidades, dar-se-á como tácita a concordância com o seu conteúdo.

$\S 4^{\circ}$. O INCRA terá um prazo de 30 (trinta) dias para adotar as medidas cabíveis diante de eventuais manifestações dos órgãos e entidades.

$\S 5^{\circ}$. Fica assegurado à comunidade interessada o acesso imediato à cópia das manifestações dos órgãos e entidades referidos neste artigo, bem como o acompanhamento das medidas decorrentes das respectivas manifestações.

\section{CONTESTAÇÕES}

Art. 13. Os interessados terão o prazo de noventa dias, após a publicação e as notificações, para contestarem o RTID junto à Superintendência Regional do INCRA, juntando as provas pertinentes.

Parágrafo único. As contestações oferecidas pelos interessados serão recebidas nos efeitos devolutivo e suspensivo.

Art. 14. As contestações dos interessados indicados no art. 12 serão analisadas e julgadas pelo Comitê de Decisão Regional do INCRA, após ouvidos os setores técnicos e a Procuradoria Regional em prazo comum de até 180 (cento e oitenta) dias, a contar do protocolo da contestação.

$\S 1^{\circ}$. Se o julgamento das contestações implicar a alteração das informações contidas no edital de que trata o art. 11, será realizada nova publicação e a notificação dos interessados.

$\S 2^{\circ}$. Se o julgamento das contestações não implicar a alteração das informações contidas no edital de que trata o art. 11, serão notificados os interessados que as ofereceram. 
Art. 15. Do julgamento das contestações caberá recurso único, com efeito apenas devolutivo, ao Conselho Diretor do INCRA, no prazo de 30 (trinta) dias, a contar da notificação.

$\S 1^{\circ}$. Sendo provido o recurso, o Presidente do INCRA publicará, no Diário Oficial da União e da unidade federativa onde se localiza a área, as eventuais alterações das informações contidas no edital de que trata o art. 11 e notificará o recorrente.

$\S 2^{\circ}$. Não sendo provido o recurso, o Presidente do INCRA notificará da decisão o recorrente.

\section{ANÁLISE DA SITUAÇÃO FUNDIÁRIA DAS ÁREAS PLEITEADAS}

Art. 16. Incidindo as terras identificadas e delimitadas pelo RTID sobre unidades de conservação constituídas, áreas de segurança nacional, áreas de faixa de fronteira e terras indígenas, a Superintendência Regional do INCRA deverá, em conjunto, respectivamente, com o Instituto Chico Mendes, a Secretaria Executiva do Conselho de Defesa Nacional ou a FUNAI, adotar as medidas cabíveis, visando a garantir a sustentabilidade dessas comunidades, conciliando os interesses do Estado.

$\S 1^{\circ}$. A Secretaria do Patrimônio da União e a Fundação Cultural Palmares serão ouvidas, em todos os casos.

$\S 2^{\circ}$. As manifestações quanto às medidas cabíveis, referidas no caput, ficarão restritas ao âmbito de cada competência institucional.

$\S 3^{\circ}$. Verificada controvérsia quanto às medidas cabíveis, de que trata o caput, o processo administrativo será encaminhado:

I - em se tratando do mérito, à Casa Civil da Presidência da República, para o exercício de sua competência de coordenação e integração das ações do Governo, prevista no art. $2^{\circ}$ da Lei $\mathrm{n}^{\circ} 10.683$, de 28 de maio de 2003;

II - sobre questão jurídica, ao Advogado-Geral da União, para o exercício de sua competência, prevista no art. $4^{\circ}$, incisò XI, da Lei Complementar $n^{\circ} 73$, de 10 de fevereiro de 1993 e o art. $8^{\circ} \mathrm{C}$, da Lei n ${ }^{\circ} 9.028$, de 12 de abril de 1995 .

$\S 4^{\circ}$. Aplica-se, no que couber, aos órgãos e entidades citados no caput e no $\S 1^{\circ}$ do art. 12 o disposto neste artigo.

$\S 5^{\circ}$. Os Órgãos e as Entidades de que trata este artigo definirão o instrumento jurídico apropriado a garantir a permanência e os usos conferidos à terra pela comunidade quilombola enquanto persistir a sobreposição de interesses.

Art. 17. Concluídas as fases a que se referem os arts. 14,15 e 16 , o Presidente do INCRA publicará, no Diário Oficial da União e da unidade federativa onde se localiza a área, portaria reconhecendo e declarando os limites da terra quilombola, no prazo de 30 (trinta) dias. 
Art. 18. Se as terras reconhecidas e declaradas incidirem sobre terrenos de marinha, marginais de rios, ilhas e lagos, a Superintendência Regional do INCRA encaminhará o processo a SPU, para a emissão de título em benefício das comunidades quilombolas.

Art. 19. Constatada a incidência nas terras reconhecidas e declaradas de posse particular sobre áreas de domínio da União, a Superintendência Regional deverá adotar as medidas cabiveis visando à retomada da área.

Art. 20. Incidindo as terras reconhecidas e declaradas sobre áreas de propriedade dos Estados, do Distrito Federal ou dos Municípios, a Superintendência Regional do INCRA encaminhará os autos para os órgãos responsáveis pela titulação no âmbito de tais entes federados.

Parágrafo único. A Superintendência Regional do INCRA poderá propor a celebração de convênio com aquelas unidades da Federação, visando à execução dos procedimentos de titulação nos termos do Decreto e desta Instrução.

Art. 21 Incidindo as terras reconhecidas e declaradas em imóvel com título de domínio particular não invalidado por nulidade, prescrição ou comisso, e nem tornado ineficaz por outros fundamentos, a Superintendencia Regional do INCRA adotará as medidas cabíveis visando à obtenção dos imóveis, mediante a instauração do procedimento de desapropriação.

Art. 22. Verificada a presença de ocupantes não quilombolas nas terras dos remanescentes das comunidades dos quilombos, a Superintendência Regional do INCRA providenciará o reassentamento em outras áreas das famílias de agricultores que preencherem os requisitos da legislação agrária.

\section{DEMARCAÇÃO}

Art. 23. A demarcação da terra reconhecida será realizada observando-se os procedimentos contidos na Norma Técnica para Georreferenciamento de imóveis rurais aprovada pela Portaria $\mathrm{n}^{\circ} 1.101$, de 19 de novembro de 2003, do Presidente do INCRA e demais atos regulamentares expedidos pela Autarquia, em atendimento à Lei $\mathrm{n}^{\circ} 10.267$, de 28 de agosto de 2001.

\section{TITULAÇ̃̃O}

Art. 24. O Presidente do INCRA realizará a titulação mediante a outorga de título coletivo e pró-indiviso à comunidade, em nome de sua associação legalmente constituída, sem nenhum ônus financeiro, com obrigatória inserção de cláusula de inalienabilidade, imprescritibilidade e de impenhorabilidade, devidamente registrada no Serviço Registral da Comarca de localização das áreas.

$\S 1^{\circ}$. Incidindo as terras reconhecidas e declaradas nas áreas previstas nos arts. 19 e 20, aos remanescentes de comunidades de quilombos fica facultada a solicitação da emissão de Título de Concessão de Direito Real de Uso Coletivo, quando couber e em caráter provisório, enquanto não se ultima a concessão do Título de

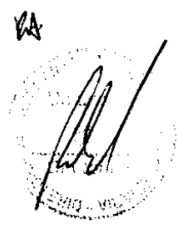


Reconhecimento de Dominio, para que possam exercer direitos reais sobre a terra que ocupam.

$\S 2^{\circ}$. A emissão do Título de Concessão de Direito Real de Uso não desobriga a concessão do Título de Reconhecimento de Domínio.

Art. 25. A expedição do título e o registro cadastral a serem procedidos pela Superintendência Regional do INCRA far-se-ão sem ônus de nenhuma espécie aos remanescentes das comunidades de quilombos, independentemente do tamanho da área.

Art. 26. Esta Instrução Normativa aplica-se desde logo, sem prejuízo da validade das fases iniciadas ou concluídas sob a vigência da Instrução Normativa anterior.

Parágrafo único. Em qualquer hipótese, contudo, pode ser aplicado o art. 16.

\section{DISPOSIÇÕES GERAIS}

Art. 27. A Superintendência Regional do INCRA promoverá, em formulários específicos, o registro cadastral dos imóveis titulados em favor dos remanescentes das comunidades dos quilombos.

Art. 28. Fica assegurada aos remanescentes das comunidades dos quilombos a participação em todas as fases do procedimento administrativo, bem como o acompanhamento dos processos de regularização em trâmite na Superintendência Regional do INCRA, diretamente ou por meio de representantes por eles indicados.

Art. 29. As despesas decorrentes da aplicação das disposições contidas nesta Instrução correrão à conta das dotações orçamentárias consignadas na lei orçamentária anual para tal finalidade, observados os limites de movimentação, empenho e pagamento.

Art. 30. A Superintendência Regional do INCRA encaminhará à Fundação Cultural Palmares e ao Instituto do Patrimônio Histórico e Artístico Nacional todas as informações relativas ao patrimônio cultural, material e imaterial, contidos no RTID, para as providências de destaque e tombamento.

Art. 31. O INCRA, através da Diretoria de Ordenamento da Estrutura Fundiária (DF) e da Coordenação Geral de Regularização de Territórios Quilombolas (DFQ), manterá o Ministério do Desenvolvimento Agrário - MDA, a Secretaria Especial de Políticas de Promoção da Igualdade Racial - SEPPIR e a Fundação Cultural Palmares informados do andamento dos processos de regularização das terras de remanescentes de quilombos.

Art. 32. Revoga-se a Instrução Normativa n² 20, de 19 de setembro de 2005.

Art. 33. Esta Instrução Normativa entra em vigor na data de sua publicação.

$$
\text { fonltukht. }
$$

ROLF HACKBART 


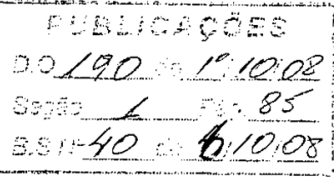

PORTARIA/INCRA/P/N $\mathbf{N}^{\circ} 32.3$

DE 29 DE SETEMBRO DE 2008.

O PRESIDENTE DO INSTITUTO NaCIONAL DE COLONIZAÇÃo E REFORMA AGRÁRIA - INCRA, no uso das atribuições que lhe são conferidas pelo inciso I e IV do art. 18, da Estrutura Regimental, aprovada pelo Decreto $\mathrm{n}^{\mathrm{0}} 5.735$, de 27 de março de 2006 , combinado com o incisos I, IV e V, do art. 110 do Regimento Interno do INCRA, aprovado pela Portaria/MDA/N 69 , de 19 de outubro de 2006, e

Art. $1^{\circ}$ Aprovar "ad referendum" do Conselho Diretor a Instrução Normativa n 49, de 29 de setembro de 2008 , que regulamenta o procedimento para identificação, reconhecimento, delimitação, demarcação, desintrusão, titulação e registro das terras ocupadas por remanescentes das comunidades dos quilombos de que tratam o Art. 68 do Ato das Disposições Constitucionais Transitórias da Constituição Federal de 1988 e o Decreto n ${ }^{\circ} 4.887$, de 20 de novembro de 2003.

Art. $2^{\circ}$ Esta Portaria entra em vigor na data de sua publicação.

Montzikist

ROLF HACKBART 


\section{ANEXO VI - DECRETO N 5.051 (BRASIL, 2004), QUE PROMULGOU A CONVENÇÃO ${ }^{\circ} 169$ DA ORGANIZAÇÃO INTERNACIONAL DO TRABALHO - OIT SOBRE POVOS INDÍGENAS E TRIBAIS.}

\section{DECRETO N 5.051, DE 19 DE ABRIL DE 2004.}

Promulga a Convenção no 169 da Organização Internacional do Trabalho - OIT sobre Povos Indígenas e Tribais.

O PRESIDENTE DA REPÚBLICA, no uso da atribuição que lhe confere o art. 84, inciso IV, da Constituição,

Considerando que o Congresso Nacional aprovou, por meio do Decreto Legislativo $\mathrm{n}^{-}$143, de 20 de junho de 2002, o texto da Convenção no 169 da Organização Internacional do Trabalho - OIT sobre Povos Indígenas e Tribais, adotada em Genebra, em 27 de junho de 1989 ;

Considerando que o Governo brasileiro depositou o instrumento de ratificação junto ao Diretor Executivo da OIT em 25 de julho de 2002;

Considerando que a Convenção entrou em vigor internacional, em 5 de setembro de 1991, e, para o Brasil, em 25 de julho de 2003, nos termos de seu art. 38;

\section{DECRETA:}

Art. 1ํ A Convenção no 169 da Organização Internacional do Trabalho - OIT sobre Povos Indígenas e Tribais, adotada em Genebra, em 27 de junho de 1989, apensa por cópia ao presente Decreto, será executada e cumprida tão inteiramente como nela se contém.

Art. $2^{\underline{o}}$ São sujeitos à aprovação do Congresso Nacional quaisquer atos que possam resultar em revisão da referida Convenção ou que acarretem encargos ou compromissos gravosos ao patrimônio nacional, nos termos do art. 49, inciso I, da Constituição Federal.

Art. $3^{\circ}$ Este Decreto entra em vigor na data de sua publicação

Brasília, 19 de abril de 2004; $183^{\circ}$ da Independência e $116^{\circ}$ da República.

LUIZ INÁCIO LULA DA SILVA

Celso Luiz Nunes Amorim

Este texto não substitui o publicado no D.O.U. de 20.4.2004

\section{CONVENÇÃO № 169 DA OIT SOBRE POVOS INDÍGENAS E TRIBAIS}

A Conferência Geral da Organização Internacional do Trabalho,

Convocada em Genebra pelo Conselho Administrativo da Repartição Internacional do Trabalho e tendo ali se reunido a 7 de junho de 1989, em sua septuagésima sexta sessão;

Observando as normas internacionais enunciadas na Convenção e na Recomendação sobre populações indígenas e tribais, 1957;

Lembrando os termos da Declaração Universal dos Direitos Humanos, do Pacto Internacional dos Direitos Econômicos, Sociais e Culturais, do Pacto Internacional dos Direitos Civis e Políticos e dos numerosos instrumentos internacionais sobre a prevenção da discriminação;

Considerando que a evolução do direito internacional desde 1957 e as mudanças sobrevindas na situação dos povos indígenas e tribais em todas as regiões do mundo fazem 
com que seja aconselhável adotar novas normas internacionais nesse assunto, a fim de se eliminar a orientação para a assimilação das normas anteriores;

Reconhecendo as aspirações desses povos a assumir o controle de suas próprias instituições e formas de vida e seu desenvolvimento econômico, e manter e fortalecer suas identidades, línguas e religiões, dentro do âmbito dos Estados onde moram;

Observando que em diversas partes do mundo esses povos não podem gozar dos direitos humanos fundamentais no mesmo grau que o restante da população dos Estados onde moram e que suas leis, valores, costumes e perspectivas têm sofrido erosão freqüientemente;

Lembrando a particular contribuição dos povos indígenas e tribais à diversidade cultural, à harmonia social e ecológica da humanidade e à cooperação e compreensão internacionais;

Observando que as disposições a seguir foram estabelecidas com a colaboração das Nações Unidas, da Organização das Nações Unidas para a Agricultura e a Alimentação, da Organização das Nações Unidas para a Educação, a Ciência e a Cultura e da Organização Mundial da Saúde, bem como do Instituto Indigenista Interamericano, nos níveis apropriados e nas suas respectivas esferas, e que existe o propósito de continuar essa colaboração a fim de promover e assegurar a aplicação destas disposições;

Após ter decidido adotar diversas propostas sobre a revisão parcial da Convenção sobre populações Indígenas e Tribais, 1957 (n.. 107), o assunto que constitui o quarto item da agenda da sessão, e

Após ter decidido que essas propostas deveriam tomar a forma de uma Convenção Internacional que revise a Convenção Sobre Populações Indígenas e Tribais, 1957, adota, neste vigésimo sétimo dia de junho de mil novecentos e oitenta e nove, a seguinte Convenção, que será denominada Convenção Sobre os Povos Indígenas e Tribais, 1989:

\section{PARTE 1 - POLÍTICA GERAL}

1. A presente convenção aplica-se:

\section{Artigo $1^{0}$}

a) aos povos tribais em países independentes, cujas condições sociais, culturais e econômicas os distingam de outros setores da coletividade nacional, e que estejam regidos, total ou parcialmente, por seus próprios costumes ou tradições ou por legislação especial;

b) aos povos em países independentes, considerados indígenas pelo fato de descenderem de populações que habitavam o país ou uma região geográfica pertencente ao país na época da conquista ou da colonização ou do estabelecimento das atuais fronteiras estatais e que, seja qual for sua situação jurídica, conservam todas as suas próprias instituições sociais, econômicas, culturais e políticas, ou parte delas.

2. A consciência de sua identidade indígena ou tribal deverá ser considerada como critério fundamental para determinar os grupos aos que se aplicam as disposições da presente Convenção.

3. A utilização do termo "povos" na presente Convenção não deverá ser interpretada no sentido de ter implicação alguma no que se refere aos direitos que possam ser conferidos a esse termo no direito internacional.

Artigo $2^{\mathrm{O}}$ 
1. Os governos deverão assumir a responsabilidade de desenvolver, com a participação dos povos interessados, uma ação coordenada e sistemática com vistas a proteger os direitos desses povos e a garantir o respeito pela sua integridade.

2. Essa ação deverá incluir medidas:

a) que assegurem aos membros desses povos o gozo, em condições de igualdade, dos direitos e oportunidades que a legislação nacional outorga aos demais membros da população;

b) que promovam a plena efetividade dos direitos sociais, econômicos e culturais desses povos, respeitando a sua identidade social e cultural, os seus costumes e tradições, e as suas instituições;

c) que ajudem os membros dos povos interessados a eliminar as diferenças sócio econômicas que possam existir entre os membros indígenas e os demais membros da comunidade nacional, de maneira compatível com suas aspirações e formas de vida.

\section{Artigo $3^{\circ}$}

1. Os povos indígenas e tribais deverão gozar plenamente dos direitos humanos e liberdades fundamentais, sem obstáculos nem discriminação. As disposições desta Convenção serão aplicadas sem discriminação aos homens e mulheres desses povos.

2. Não deverá ser empregada nenhuma forma de força ou de coerção que viole os direitos humanos e as liberdades fundamentais dos povos interessados, inclusive os direitos contidos na presente Convenção.

\section{Artigo $4^{\circ}$}

1. Deverão ser adotadas as medidas especiais que sejam necessárias para salvaguardar as pessoas, as instituições, os bens, as culturas e o meio ambiente dos povos interessados.

2. Tais medidas especiais não deverão ser contrárias aos desejos expressos livremente pelos povos interessados.

3. O gozo sem discriminação dos direitos gerais da cidadania não deverá sofrer nenhuma deterioração como conseqüência dessas medidas especiais.

\section{Artigo 5은}

Ao se aplicar as disposições da presente Convenção:

a) deverão ser reconhecidos e protegidos os valores e práticas sociais, culturais religiosos e espirituais próprios dos povos mencionados e dever-se-á levar na devida consideração a natureza dos problemas que lhes sejam apresentados, tanto coletiva como individualmente;

b) deverá ser respeitada a integridade dos valores, práticas e instituições desses povos;

c) deverão ser adotadas, com a participação e cooperação dos povos interessados, medidas voltadas a aliviar as dificuldades que esses povos experimentam ao enfrentarem novas condições de vida e de trabalho.

\section{Artigo $6^{-}$}

1. Ao aplicar as disposições da presente Convenção, os governos deverão:

a) consultar os povos interessados, mediante procedimentos apropriados e, particularmente, através de suas instituições representativas, cada vez que sejam previstas medidas legislativas ou administrativas suscetíveis de afetá-los diretamente;

b) estabelecer os meios através dos quais os povos interessados possam participar livremente, pelo menos na mesma medida que outros setores da população e em todos os níveis, na adoção de decisões em instituições efetivas ou organismos administrativos e de outra natureza responsáveis pelas políticas e programas que lhes sejam concernentes; 
c) estabelecer os meios para o pleno desenvolvimento das instituições e iniciativas dos povos e, nos casos apropriados, fornecer os recursos necessários para esse fim.

2. As consultas realizadas na aplicação desta Convenção deverão ser efetuadas com boa fé e de maneira apropriada às circunstâncias, com o objetivo de se chegar a um acordo e conseguir o consentimento acerca das medidas propostas.

\section{Artigo $7^{0}$}

1. Os povos interessados deverão ter o direito de escolher suas, próprias prioridades no que diz respeito ao processo de desenvolvimento, na medida em que ele afete as suas vidas, crenças, instituições e bem-estar espiritual, bem como as terras que ocupam ou utilizam de alguma forma, e de controlar, na medida do possível, o seu próprio desenvolvimento econômico, social e cultural. Além disso, esses povos deverão participar da formulação, aplicação e avaliação dos planos e programas de desenvolvimento nacional e regional suscetíveis de afetá-los diretamente.

2. A melhoria das condições de vida e de trabalho e do nível de saúde e educação dos povos interessados, com a sua participação e cooperação, deverá ser prioritária nos planos de desenvolvimento econômico global das regiões onde eles moram. Os projetos especiais de desenvolvimento para essas regiões também deverão ser elaborados de forma a promoverem essa melhoria.

3. Os governos deverão zelar para que, sempre que for possíve1, sejam efetuados estudos junto aos povos interessados com o objetivo de se avaliar a incidência social, espiritual e cultural e sobre o meio ambiente que as atividades de desenvolvimento, previstas, possam ter sobre esses povos. Os resultados desses estudos deverão ser considerados como critérios fundamentais para a execução das atividades mencionadas.

4. Os governos deverão adotar medidas em cooperação com os povos interessados para proteger e preservar o meio ambiente dos territórios que eles habitam.

\section{Artigo $8^{\circ}$}

1. Ao aplicar a legislação nacional aos povos interessados deverão ser levados na devida consideração seus costumes ou seu direito consuetudinário.

2. Esses povos deverão ter o direito de conservar seus costumes e instituições próprias, desde que eles não sejam incompatíveis com os direitos fundamentais definidos pelo sistema jurídico nacional nem com os direitos humanos internacionalmente reconhecidos. Sempre que for necessário, deverão ser estabelecidos procedimentos para se solucionar os conflitos que possam surgir na aplicação deste principio.

3. A aplicação dos parágrafos 1 e 2 deste Artigo não deverá impedir que os membros desses povos exerçam os direitos reconhecidos para todos os cidadãos do país e assumam as obrigações correspondentes.

Artigo 9음

1. Na medida em que isso for compatível com o sistema jurídico nacional e com os direitos humanos internacionalmente reconhecidos, deverão ser respeitados os métodos aos quais os povos interessados recorrem tradicionalmente para a repressão dos delitos cometidos pelos seus membros.

2. As autoridades e os tribunais solicitados para se pronunciarem sobre questões penais deverão levar em conta os costumes dos povos mencionados a respeito do assunto.

\section{Artigo 10}

1. Quando sanções penais sejam impostas pela legislação geral a membros dos povos mencionados, deverão ser levadas em conta as suas características econômicas, sociais e culturais. 
2. Dever-se-á dar preferência a tipos de punição outros que o encarceramento.

Artigo 11

A lei deverá proibir a imposição, a membros dos povo interessados, de serviços pessoais obrigatórios de qualquer natureza, remunerados ou não, exceto nos casos previstos pela lei para todos os cidadãos.

\section{Artigo 12}

Os povos interessados deverão ter proteção contra a violação de seus direitos, e poder iniciar procedimentos legais, seja pessoalmente, seja mediante os seus organismos representativos, para assegurar o respeito efetivo desses direitos. Deverão ser adotadas medidas para garantir que os membros desses povos possam compreender e se fazer compreender em procedimentos legais, facilitando para eles, se for necessário, intérpretes ou outros meios eficazes.

\section{PARTE II - TERRAS}

\section{Artigo 13}

1. Ao aplicarem as disposições desta parte da Convenção, os governos deverão respeitar a importância especial que para as culturas e valores espirituais dos povos interessados possui a sua relação com as terras ou territórios, ou com ambos, segundo os casos, que eles ocupam ou utilizam de alguma maneira e, particularmente, os aspectos coletivos dessa relação.

2. A utilização do termo "terras" nos Artigos 15 e 16 deverá incluir o conceito de territórios, o que abrange a totalidade do habitat das regiões que os povos interessados ocupam ou utilizam de alguma outra forma.

\section{Artigo 14}

1. Dever-se-á reconhecer aos povos interessados os direitos de propriedade e de posse sobre as terras que tradicionalmente ocupam. Além disso, nos casos apropriados, deverão ser adotadas medidas para salvaguardar o direito dos povos interessados de utilizar terras que não estejam exclusivamente ocupadas por eles, mas às quais, tradicionalmente, tenham tido acesso para suas atividades tradicionais e de subsistência. Nesse particular, deverá ser dada especial atenção à situação dos povos nômades e dos agricultores itinerantes.

2. Os governos deverão adotar as medidas que sejam necessárias para determinar as terras que os povos interessados ocupam tradicionalmente e garantir a proteção efetiva dos seus direitos de propriedade e posse.

3. Deverão ser instituídos procedimentos adequados no âmbito do sistema jurídico nacional para solucionar as reivindicações de terras formuladas pelos povos interessados.

\section{Artigo 15}

1. Os direitos dos povos interessados aos recursos naturais existentes nas suas terras deverão ser especialmente protegidos. Esses direitos abrangem o direito desses povos a participarem da utilização, administração e conservação dos recursos mencionados.

2. Em caso de pertencer ao Estado a propriedade dos minérios ou dos recursos do subsolo, ou de ter direitos sobre outros recursos, existentes na terras, os governos deverão estabelecer ou manter procedimentos com vistas a consultar os povos interessados, a fim de se determinar se os interesses desses povos seriam prejudicados, e em que medida, antes de se empreender ou autorizar qualquer programa de prospecção ou exploração dos recursos existentes nas suas terras. Os povos interessados deverão participar sempre que for possível 
dos benefícios que essas atividades produzam, e receber indenização equitativa por qualquer dano que possam sofrer como resultado dessas atividades.

\section{Artigo 16}

1. Com reserva do disposto nos parágrafos a seguir do presente Artigo, os povos interessados não deverão ser transladados das terras que ocupam.

2. Quando, excepcionalmente, o translado e o reassentamento desses povos sejam considerados necessários, só poderão ser efetuados com o consentimento dos mesmos, concedido livremente e com pleno conhecimento de causa. Quando não for possível obter o seu consentimento, o translado e o reassentamento só poderão ser realizados após a conclusão de procedimentos adequados estabelecidos pela legislação nacional, inclusive enquetes públicas, quando for apropriado, nas quais os povos interessados tenham a possibilidade de estar efetivamente representados.

3. Sempre que for possível, esses povos deverão ter o direito de voltar a suas terras tradicionais assim que deixarem de existir as causas que motivaram seu translado e reassentamento.

4. Quando o retorno não for possível, conforme for determinado por acordo ou, na ausência de tais acordos, mediante procedimento adequado, esses povos deverão receber, em todos os casos em que for possível, terras cuja qualidade e cujo estatuto jurídico sejam pelo menos iguais aqueles das terras que ocupavam anteriormente, e que lhes permitam cobrir suas necessidades e garantir seu desenvolvimento futuro. Quando os povos interessados prefiram receber indenização em dinheiro ou em bens, essa indenização deverá ser concedida com as garantias apropriadas.

5. Deverão ser indenizadas plenamente as pessoas transladadas e reassentadas por qualquer perda ou dano que tenham sofrido como conseqüência do seu deslocamento.

\section{Artigo 17}

1. Deverão ser respeitadas as modalidades de transmissão dos direitos sobre a terra entre os membros dos povos interessados estabelecidas por esses povos.

2. Os povos interessados deverão ser consultados sempre que for considerada sua capacidade para alienarem suas terras ou transmitirem de outra forma os seus direitos sobre essas terras para fora de sua comunidade.

3. Dever-se-á impedir que pessoas alheias a esses povos possam se aproveitar dos costumes dos mesmos ou do desconhecimento das leis por parte dos seus membros para se arrogarem a propriedade, a posse ou o uso das terras a eles pertencentes.

\section{Artigo 18}

A lei deverá prever sanções apropriadas contra toda intrusão não autorizada nas terras dos povos interessados ou contra todo uso não autorizado das mesmas por pessoas alheias a eles, e os governos deverão adotar medidas para impedirem tais infrações.

\section{Artigo 19}

Os programas agrários nacionais deverão garantir aos povos interessados condições equivalentes às desfrutadas por outros setores da população, para fins de:

a) a alocação de terras para esses povos quando as terras das que dispunham sejam insuficientes para lhes garantir os elementos de uma existência normal ou para enfrentarem o seu possível crescimento numérico;

b) a concessão dos meios necessários para o desenvolvimento das terras que esses povos já possuam. 


\section{PARTE III - CONTRATAÇÃO E CONDIÇÕES DE EMPREGO}

Artigo 20

1. Os governos deverão adotar, no âmbito da legislação nacional e em cooperação com os povos interessados, medidas especiais para garantir aos trabalhadores pertencentes a esses povos uma proteção eficaz em matéria de contratação e condições de emprego, na medida em que não estejam protegidas eficazmente pela legislação aplicável aos trabalhadores em geral.

2. Os governos deverão fazer o que estiver ao seu alcance para evitar qualquer discriminação entre os trabalhadores pertencentes ao povos interessados e os demais trabalhadores, especialmente quanto a:

a) acesso ao emprego, inclusive aos empregos qualificados e às medidas de promoção e ascensão;

b) remuneração igual por trabalho de igual valor;

c) assistência médica e social, segurança e higiene no trabalho, todos os benefícios da seguridade social e demais benefícios derivados do emprego, bem como a habitação;

d) direito de associação, direito a se dedicar livremente a todas as atividades sindicais para fins lícitos, e direito a celebrar convênios coletivos com empregadores ou com organizações patronais.

3. As medidas adotadas deverão garantir, particularmente, que:

a) os trabalhadores pertencentes aos povos interessados, inclusive os trabalhadores sazonais, eventuais e migrantes empregados na agricultura ou em outras atividades, bem como os empregados por empreiteiros de mão-de-obra, gozem da proteção conferida pela legislação e a prática nacionais a outros trabalhadores dessas categorias nos mesmos setores, e sejam plenamente informados dos seus direitos de acordo com a legislação trabalhista e dos recursos de que dispõem;

b) os trabalhadores pertencentes a esses povos não estejam submetidos a condições de trabalho perigosas para sua saúde, em particular como consequiência de sua exposição a pesticidas ou a outras substâncias tóxicas;

c) os trabalhadores pertencentes a esses povos não sejam submetidos a sistemas de contratação coercitivos, incluindo-se todas as formas de servidão por dívidas;

d) os trabalhadores pertencentes a esses povos gozem da igualdade de oportunidade e de tratamento para homens e mulheres no emprego e de proteção contra o acossamento sexual.

4. Dever-se-á dar especial atenção à criação de serviços adequados de inspeção do trabalho nas regiões donde trabalhadores pertencentes aos povos interessados exerçam atividades assalariadas, a fim de garantir o cumprimento das disposições desta parte da presente Convenção.

\section{INDÚSTRIAS RURAIS}

Artigo 21

Os membros dos povos interessados deverão poder dispor de meios de formação profissional pelo menos iguais àqueles dos demais cidadãos.

Artigo 22 
1. Deverão ser adotadas medidas para promover a participação voluntária de membros dos povos interessados em programas de formação profissional de aplicação geral.

2. Quando os programas de formação profissional de aplicação geral existentes não atendam as necessidades especiais dos povos interessados, os governos deverão assegurar, com a participação desses povos, que sejam colocados à disposição dos mesmos programas e meios especiais de formação.

3. Esses programas especiais de formação deverão estar baseado no entorno econômico, nas condições sociais e culturais e nas necessidades concretas dos povos interessados. Todo levantamento neste particular deverá ser realizado em cooperação com esses povos, os quais deverão ser consultados sobre a organização e o funcionamento de tais programas. Quando for possível, esses povos deverão assumir progressivamente a responsabilidade pela organização e o funcionamento de tais programas especiais de formação, se assim decidirem.

\section{Artigo 23}

1. O artesanato, as indústrias rurais e comunitárias e as atividades tradicionais e relacionadas com a economia de subsistência dos povos interessados, tais como a caça, a pesca com armadilhas e a colheita, deverão ser reconhecidas como fatores importantes da manutenção de sua cultura e da sua autosuficiência e desenvolvimento econômico. Com a participação desses povos, e sempre que for adequado, os governos deverão zelar para que sejam fortalecidas e fomentadas essas atividades.

2. A pedido dos povos interessados, deverá facilitar-se aos mesmos, quando for possível, assistência técnica e financeira apropriada que leve em conta as técnicas tradicionais e as características culturais desses povos e a importância do desenvolvimento sustentado e equitativo.

\section{PARTE V - SEGURIDADE SOCIAL E SAÚDE}

Artigo 24

Os regimes de seguridade social deverão ser estendidos progressivamente aos povos interessados e aplicados aos mesmos sem discriminação alguma.

\section{Artigo 25}

1. Os governos deverão zelar para que sejam colocados à disposição dos povos interessados serviços de saúde adequados ou proporcionar a esses povos os meios que lhes permitam organizar e prestar tais serviços sob a sua própria responsabilidade e controle, a fim de que possam gozar do nível máximo possível de saúde física e mental.

2. Os serviços de saúde deverão ser organizados, na medida do possível, em nível comunitário. Esses serviços deverão ser planejados e administrados em cooperação com os povos interessados e levar em conta as suas condições econômicas, geográficas, sociais e culturais, bem como os seus métodos de prevenção, práticas curativas e medicamentos tradicionais.

3. O sistema de assistência sanitária deverá dar preferência à formação e ao emprego de pessoal sanitário da comunidade local e se centrar no atendimento primário à saúde, mantendo ao mesmo tempo estreitos vínculos com os demais níveis de assistência sanitária.

4. A prestação desses serviços de saúde deverá ser coordenada com as demais medidas econômicas e culturais que sejam adotadas no país.

\section{PARTE VI - EDUCAÇÃO E MEIOS DE COMUNICAÇÃO}


Artigo 26

Deverão ser adotadas medidas para garantir aos membros dos povos interessados a possibilidade de adquirirem educação em todos o níveis, pelo menos em condições de igualdade com o restante da comunidade nacional.

\section{Artigo 27}

1. Os programas e os serviços de educação destinados aos povos interessados deverão ser desenvolvidos e aplicados em cooperação com eles a fim de responder às suas necessidades particulares, e deverão abranger a sua história, seus conhecimentos e técnicas, seus sistemas de valores e todas suas demais aspirações sociais, econômicas e culturais.

2. A autoridade competente deverá assegurar a formação de membros destes povos e a sua participação na formulação e execução de programas de educação, com vistas a transferir progressivamente para esses povos a responsabilidade de realização desses programas, quando for adequado.

3. Além disso, os governos deverão reconhecer o direito desses povos de criarem suas próprias instituições e meios de educação, desde que tais instituições satisfaçam as normas mínimas estabelecidas pela autoridade competente em consulta com esses povos. Deverão ser facilitados para eles recursos apropriados para essa finalidade.

Artigo 28

1. Sempre que for viável, dever-se-á ensinar às crianças dos povos interessados a ler e escrever na sua própria língua indígena ou na língua mais comumente falada no grupo a que pertençam. Quando isso não for viável, as autoridades competentes deverão efetuar consultas com esses povos com vistas a se adotar medidas que permitam atingir esse objetivo.

2. Deverão ser adotadas medidas adequadas para assegurar que esses povos tenham a oportunidade de chegarem a dominar a língua nacional ou uma das línguas oficiais do país.

3. Deverão ser adotadas disposições para se preservar as línguas indígenas dos povos interessados e promover o desenvolvimento e prática das mesmas.

Artigo 29

Um objetivo da educação das crianças dos povos interessados deverá ser o de lhes ministrar conhecimentos gerais e aptidões que lhes permitam participar plenamente e em condições de igualdade na vida de sua própria comunidade e na da comunidade nacional. Artigo 30

1. Os governos deverão adotar medidas de acordo com as tradições e culturas dos povos interessados, a fim de lhes dar a conhecer seus direitos e obrigações especialmente no referente ao trabalho e às possibilidades econômicas, às questões de educação e saúde, aos serviços sociais e aos direitos derivados da presente Convenção.

2. Para esse fim, dever-se-á recorrer, se for necessário, a traduções escritas e à utilização dos meios de comunicação de massa nas línguas desses povos.

Artigo 31

Deverão ser adotadas medidas de caráter educativo em todos os setores da comunidade nacional, e especialmente naqueles que estejam em contato mais direto com os povos interessados, com o objetivo de se eliminar os preconceitos que poderiam ter com relação a esses povos. Para esse fim, deverão ser realizados esforços para assegurar que os livros de História e demais materiais didáticos ofereçam uma descrição equitativa, exata e instrutiva das sociedades e culturas dos povos interessados. 


\section{PARTE VII - CONTATOS E COOPERAÇÃO ATRAVÉS DAS FRONTEIRAS}

\section{Artigo 32}

Os governos deverão adotar medidas apropriadas, inclusive mediante acordos internacionais, para facilitar os contatos e a cooperação entre povos indígenas e tribais através das fronteiras, inclusive as atividades nas áreas econômica, social, cultural, espiritual e do meio ambiente.

\section{PARTE VIII - ADMINISTRAÇÃO}

Artigo 33

1. A autoridade governamental responsável pelas questões que a presente Convenção abrange deverá se assegurar de que existem instituições ou outros mecanismos apropriados para administrar os programas que afetam os povos interessados, e de que tais instituições ou mecanismos dispõem dos meios necessários para o pleno desempenho de suas funções.

2. Tais programas deverão incluir:

a) o planejamento, coordenação, execução e avaliação, em cooperação com os povos interessados, das medidas previstas na presente Convenção;

b) a proposta de medidas legislativas e de outra natureza às autoridades competentes e o controle da aplicação das medidas adotadas em cooperação com os povos interessados.

\section{PARTE IX - DISPOSIÇÕES GERAIS}

\section{Artigo 34}

A natureza e o alcance das medidas que sejam adotadas para por em efeito a presente Convenção deverão ser determinadas com flexibilidade, levando em conta as condições próprias de cada país.

\section{Artigo 35}

A aplicação das disposições da presente Convenção não deverá prejudicar os direitos e as vantagens garantidos aos povos interessados em virtude de outras convenções e recomendações, instrumentos internacionais, tratados, ou leis, laudos, costumes ou acordos nacionais.

\section{PARTE X - DISPOSIÇÕES FINAIS}

Artigo 36

Esta Convenção revisa a Convenção Sobre Populações Indígenas e Tribais, 1957. Artigo 37

As ratificações formais da presente Convenção serão transmitidas ao Diretor-Geral da Repartição Internacional do Trabalho e por ele registradas.

Artigo 38

1. A presente Convenção somente vinculará os Membros da Organização Internacional do Trabalho cujas ratificações tenham sido registradas pelo Diretor-Geral.

2. Esta Convenção entrará em vigor doze meses após o registro das ratificações de dois Membros por parte do Diretor-Geral.

3. Posteriormente, esta Convenção entrará em vigor, para cada Membro, doze meses após o registro da sua ratificação. 


\section{Artigo 39}

1. Todo Membro que tenha ratificado a presente Convenção poderá denunciá-la após a expiração de um período de dez anos contados da entrada em vigor mediante ato comunicado ao Diretor-Geral da Repartição Internacional do Trabalho e por ele registrado. A denúncia só surtirá efeito um ano após o registro.

2. Todo Membro que tenha ratificado a presente Convenção e não fizer uso da faculdade de denúncia prevista pelo parágrafo precedente dentro do prazo de um ano após a expiração do período de dez anos previsto pelo presente Artigo, ficará obrigado por um novo período de dez anos e, posteriormente, poderá denunciar a presente Convenção ao expirar cada período de dez anos, nas condições previstas no presente Artigo.

\section{Artigo 40}

1. O Diretor-Geral da Repartição Internacional do Trabalho notificará a todos os Membros da Organização Internacional do Trabalho o registro de todas as ratificações, declarações e denúncias que lhe sejam comunicadas pelos Membros da Organização.

2. Ao notificar aos Membros da Organização o registro da segundo ratificação que lhe tenha sido comunicada, o Diretor-Geral chamará atenção dos Membros da Organização para a data de entrada em vigor da presente Convenção.

Artigo 41

O Diretor-Geral da Repartição Internacional do Trabalho comunicará ao Secretário Geral das Nações Unidas, para fins de registro, conforme o Artigo 102 da Carta das Nações Unidas, as informações completas referentes a quaisquer ratificações, declarações e atos de denúncia que tenha registrado de acordo com os Artigos anteriores.

\section{Artigo 42}

Sempre que julgar necessário, o Conselho de Administração da Repartição Internacional do Trabalho deverá apresentar à Conferência Geral um relatório sobre a aplicação da presente Convenção e decidirá sobre a oportunidade de inscrever na agenda da Conferência a questão de sua revisão total ou parcial.

\section{Artigo 43}

1. Se a Conferência adotar uma nova Convenção que revise total ou parcialmente a presente Convenção, e a menos que a nova Convenção disponha contrariamente:

a) a ratificação, por um Membro, da nova Convenção revista implicará de pleno direito, não obstante o disposto pelo Artigo 39, supra, a denúncia imediata da presente Convenção, desde que a nova Convenção revista tenha entrado em vigor;

b) a partir da entrada em vigor da Convenção revista, a presente Convenção deixará de estar aberta à ratificação dos Membros.

2. A presente Convenção continuará em vigor, em qualquer caso em sua forma e teor atuais, para os Membros que a tiverem ratificado e que não ratificarem a Convenção revista.

\section{Artigo 44}

As versões inglesa e francesa do texto da presente Convenção são igualmente autênticas. 
